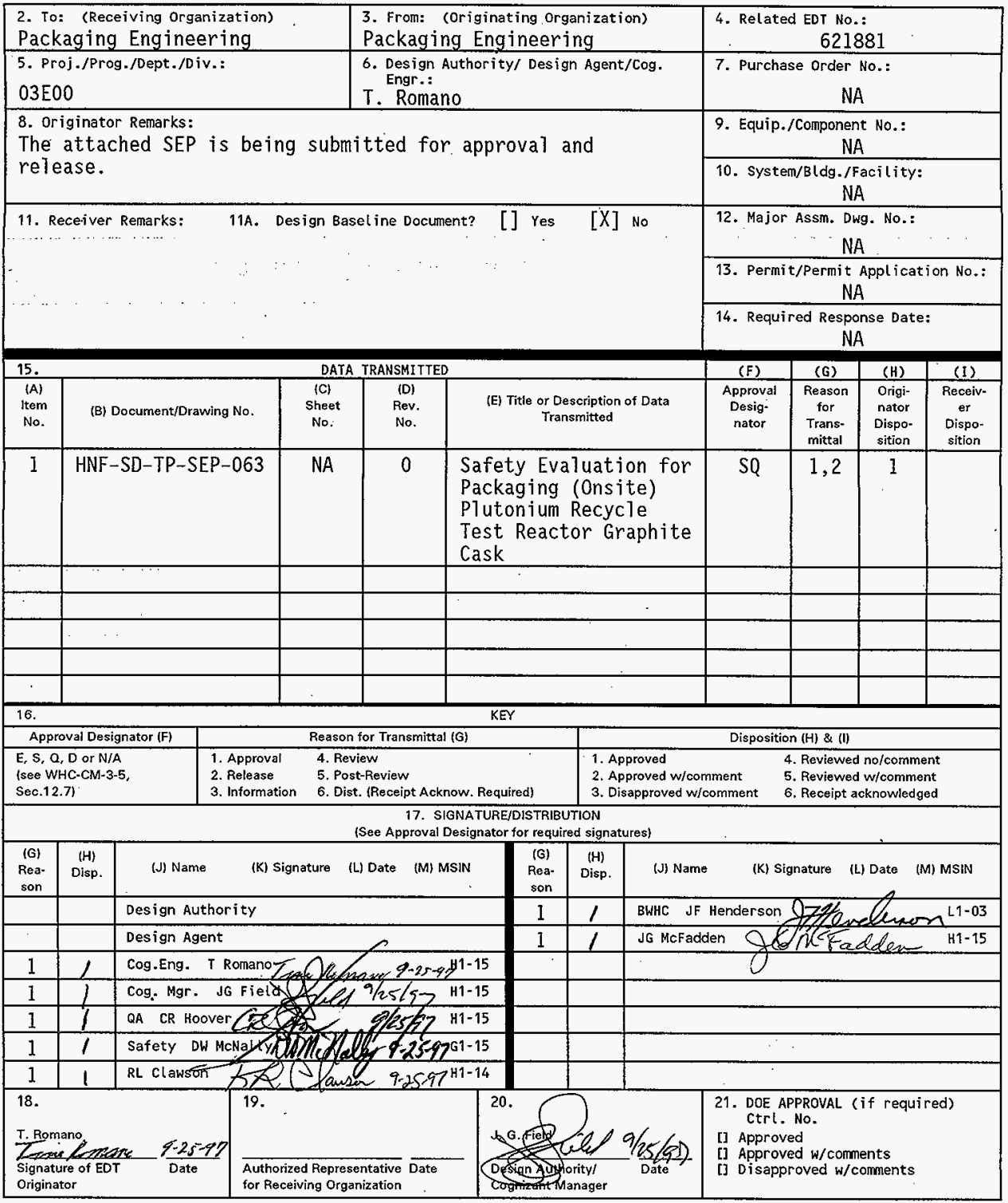




\title{
Safety Evaluation for Packaging (Onsite) Plutonium Recycle Test Reactor Graphite Cask
}

\author{
T. Romano \\ Richland, Washington 99352 \\ U.S. Department of Energy Contract DE-AC06-96RL13200 \\ EDT/ECN: EDT 621885 \\ Org Code: 03E00 \\ B\&R Code: EX3120020 \\ UC: 513 \\ Charge Code: K7A21 \\ Total Pages: 178
}

Waste Management Federal Services, Inc., Northwest Operations

Key Words: transfer, PRTR Graphite Cask, 327 Building, 300 Area, Type B, mixed oxide fuel, metal oxide fuel

Abstract: This safety eva1uation for packaging (SEP) provides the evaTuation necessary to demonstrate that the Plutonium Recycle Test Reactor (PRTR) Graphite Cask meets the requirements of WHC-CM-2-14, Hazardous Material Packaging and Shipping, for transfer of Type B, fissile, non-highway route controlled quantities of radioactive material within the 300 Area of the Hanford Site. The scope of this SEP includes risk, shieldling, criticality, and tiedown analyses to demonstrate that onsite transportation safety requirements are satisfied. This SEP also establishes operational and maintenance guidelines to ensure that transport of the PRTR Graphite Cask is performed safely in accordance with WHC-CM-2-14. This SEP is valid until October 1, 1999. After this date, an update or upgrade to this document is required.

TRADEMARK DISCLAIMER. Reference herein to any specific comercial product, process, or service by trade name, trademark, manufacturer, or otherwise, does not necessarily constitute or imply its endorsement, recommendation, or favoring by the United States Government or any agency thereof or its contractors or subcontractors.

Printed in the United States of America. ro obtain copies of this document, contact: WHC/BCS Document Control Services, P.O. Box 1970, Mailstop H6-08, Richland WA 99352, Phone (509) 372-2420; Fax (509) $376-4989$
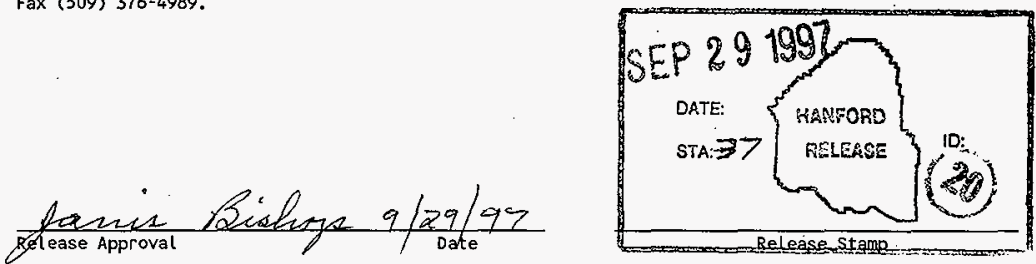

\section{Approved for Public Release}


CONTENTS

PART A: DESCRIPTION AND OPERATIONS

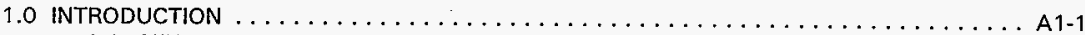

1.1 GENERAL INFORMATION $\ldots \ldots \ldots \ldots \ldots \ldots \ldots \ldots \ldots \ldots \ldots \ldots \ldots \ldots \ldots \ldots \ldots$

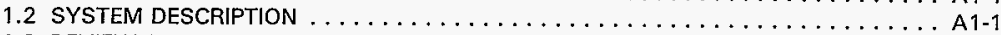

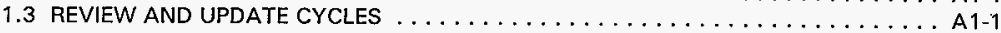

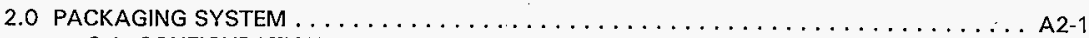

2.1 CONFIGURATION AND DIMENSIONS $\ldots \ldots \ldots \ldots \ldots \ldots \ldots \ldots \ldots \ldots \ldots \ldots \ldots$ A2-1

2.2 MATERIALS OF CONSTRUCTION $\ldots \ldots \ldots \ldots \ldots \ldots \ldots \ldots \ldots \ldots \ldots \ldots \ldots \ldots \ldots$ A2-1

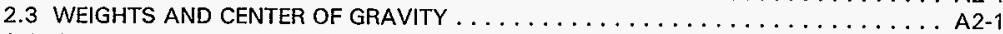

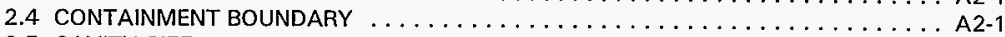

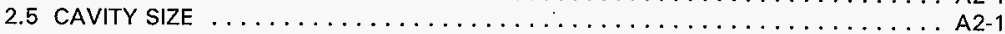

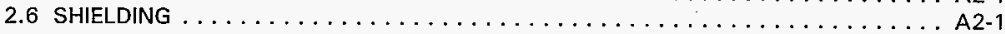

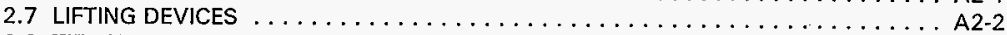

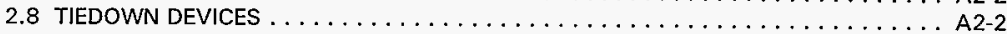

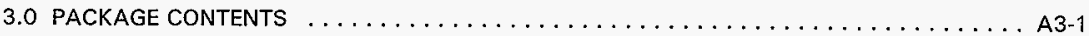

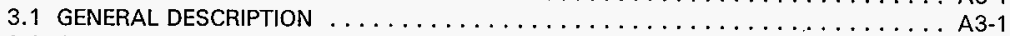

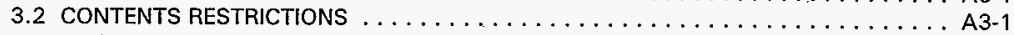

3.2.1 Radioactive Materials . . . . . . . . . . . . . . . . . A3-1

3.2 .2 Nonradioactive Hazardous Materials . . . . . . . . . . . . . A3-1

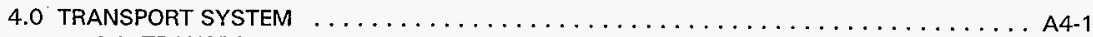

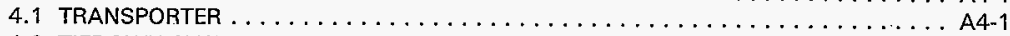

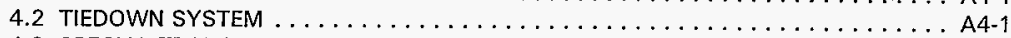

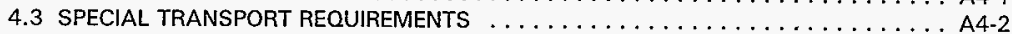

4.3.1 Routing and Access Control . . . . . . . . . . . . . . . . . . A4-2

4.3.2 Radiological Limitations . . . . . . . . . . . . . . . . . A4-2

4.3 .3 Speed Limitations $\ldots \ldots \ldots \ldots \ldots \ldots \ldots \ldots \ldots \ldots \ldots \ldots \ldots \ldots$ A4-2

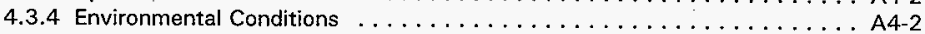

4.3.5 Frequency of Use and Mileage Limitations $\ldots \ldots \ldots \ldots \ldots \ldots \ldots \ldots$ A4-3

4.3.6 Emergency Response $\ldots \ldots \ldots \ldots \ldots \ldots \ldots \ldots \ldots \ldots \ldots \ldots \ldots$ A4-3

5.0 ACCEPTANCE OF PACKAGING FOR USE $\ldots \ldots \ldots \ldots \ldots \ldots \ldots \ldots \ldots \ldots \ldots \ldots \ldots$ A $1 \ldots \ldots \ldots$

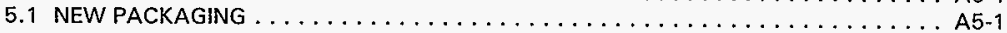

5.2 PACKAGING FOR REUSE $\ldots \ldots \ldots \ldots \ldots \ldots \ldots \ldots \ldots \ldots \ldots \ldots \ldots \ldots$ A5-1

6.0 OPERATING REQUIREMENTS $\ldots \ldots \ldots \ldots \ldots \ldots \ldots \ldots \ldots \ldots \ldots \ldots \ldots \ldots \ldots \ldots \ldots$ A6-1

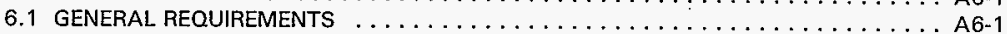

6.2 LOADING OF CONTENTS INTO THE CASK $\ldots \ldots \ldots \ldots \ldots \ldots \ldots \ldots \ldots \ldots \ldots \ldots$ A6-1

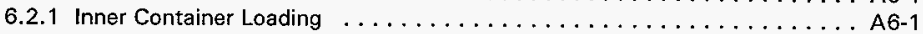

6.2 .2 Preparing the Cask for Loading $\ldots \ldots \ldots \ldots \ldots \ldots \ldots \ldots \ldots \ldots$ A6-1

6.2 .3 Loading Contents into the Cask . . . . . . . . . . . . . . . A6-2

6.3 PREPARATION OF THE CASK FOR SHIPMENT $\ldots \ldots \ldots \ldots \ldots \ldots \ldots \ldots \ldots \ldots \ldots$ A6-2

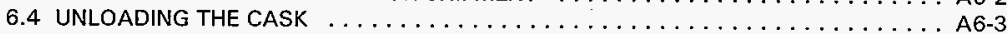

6.5 EMPTY PACKAGING $\ldots \ldots \ldots \ldots \ldots \ldots \ldots \ldots \ldots \ldots \ldots \ldots \ldots \ldots \ldots \ldots$ A6-3 


\section{CONTENTS (cont)}

7.0 QUALITY ASSURANCE REQUIREMENTS

A7-1

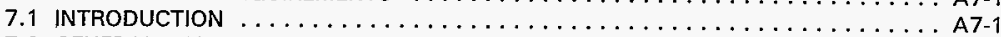

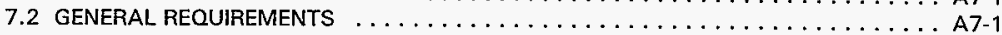

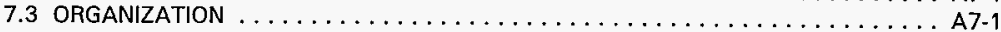

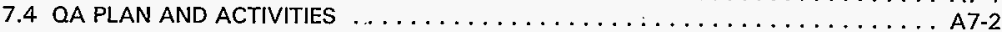

7.4.1 Design Control . . . . . . . . . . . . . . . . . . . . A7-2

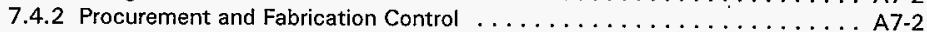

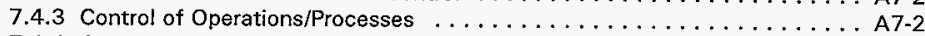

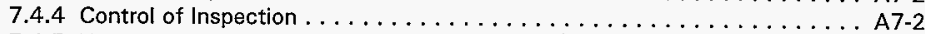

7.4 .5 Test Control . . . . . . . . . . . . . . . . . . . . A7-2

7.4.6 Control of Measuring and Test Equipment $\ldots \ldots \ldots \ldots \ldots \ldots \ldots \ldots \ldots$ A7-2

7.4 .7 Control of Nonconforming Items $\ldots \ldots \ldots \ldots \ldots \ldots \ldots \ldots \ldots \ldots \ldots \ldots$ A7-2

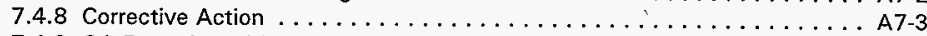

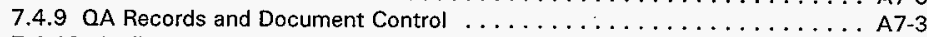

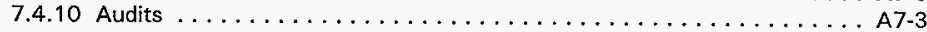

8.0 MAINTENANCE $\ldots \ldots \ldots \ldots \ldots \ldots \ldots \ldots \ldots \ldots \ldots \ldots \ldots \ldots \ldots \ldots \ldots$

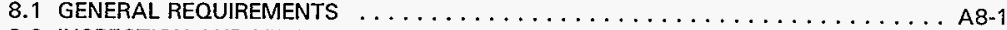

8.2 INSPECTION AND VERIFICATION SCHEDULES $\ldots \ldots \ldots \ldots \ldots \ldots \ldots \ldots \ldots \ldots \ldots$ A8-1

8.3 RECORDS AND DOCUMENTATION $\ldots \ldots \ldots \ldots \ldots \ldots \ldots \ldots \ldots \ldots \ldots \ldots \ldots \ldots \ldots$

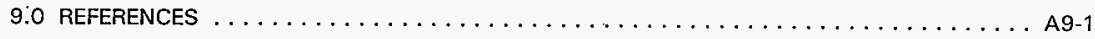

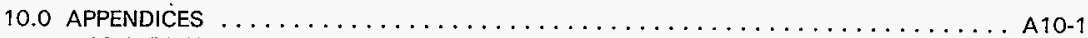

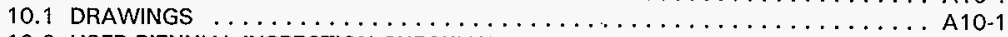

10.2 USER BIENNIAL INSPECTION CHECKLIST AND NONDESTRUCTIVE TESTING OF LIFTING APPARATUS

A 10-17

PART B: PACKAGE EVALUATION

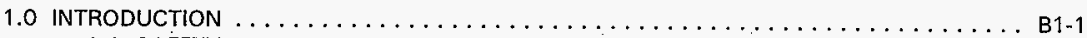

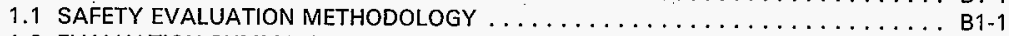

1.2 EVALUATION SUMMARY AND CONCLUSIONS ................

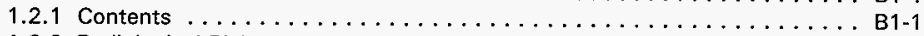

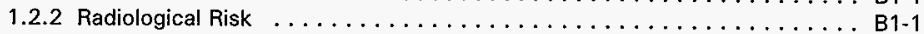

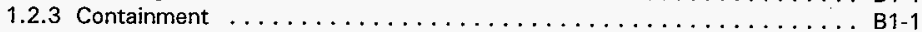

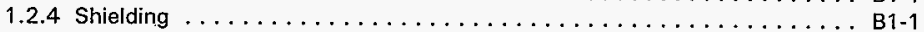

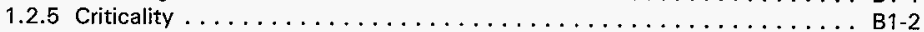

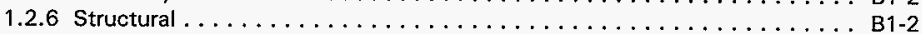

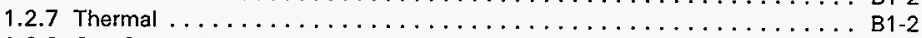

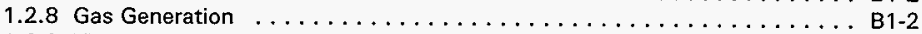

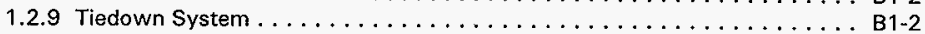

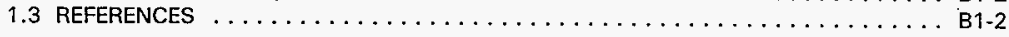

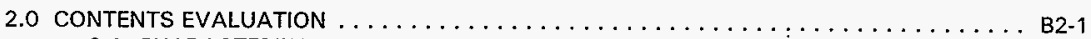

2.1 CHARACTERIZATION $\ldots \ldots \ldots \ldots \ldots \ldots \ldots \ldots \ldots \ldots \ldots \ldots \ldots \ldots \ldots \ldots$ B2-1

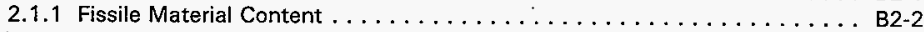

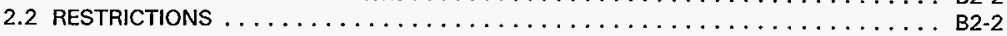


CONTENTS (cont)

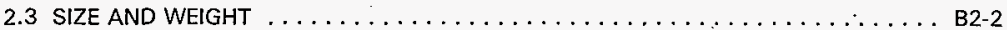

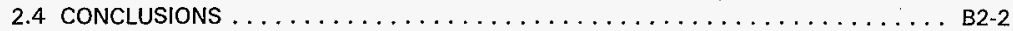

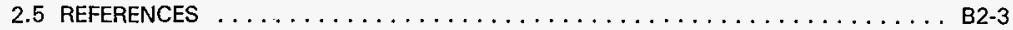

3.0 RADIOLOGICAL RISK EVALUATION $\ldots \ldots \ldots \ldots \ldots \ldots \ldots \ldots \ldots \ldots \ldots \ldots \ldots \ldots \ldots \ldots$

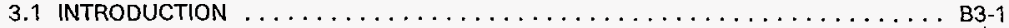

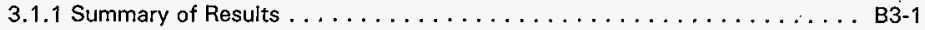

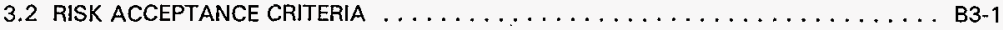

3.3 DOSE CONSEQUENCE ANALYSIS RESULTS $\ldots \ldots \ldots \ldots \ldots \ldots \ldots \ldots \ldots \ldots$ B3-2

3.4 PACKAGE FAILURE THRESHOLD ANALYSIS $\ldots \ldots \ldots \ldots \ldots \ldots \ldots \ldots \ldots \ldots \ldots$

3.5 ACCIDENT RELEASE FREQUENCY ASSESSMENT $\ldots \ldots \ldots \ldots \ldots \ldots \ldots \ldots$ B3-3

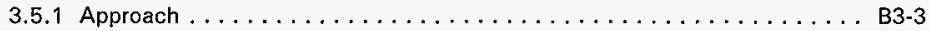

3.5 .2 Accident Release Frequency Analysis . . . . . . . . . . . . B3-4

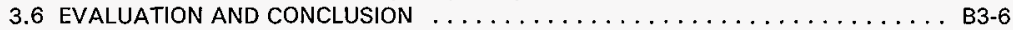

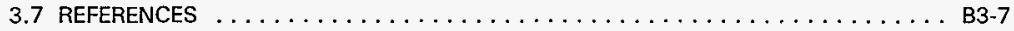

3.8 APPENDIX: CHECKLIST FOR REVIEW $\ldots \ldots \ldots \ldots \ldots \ldots \ldots \ldots \ldots \ldots \ldots \ldots$ B3-8

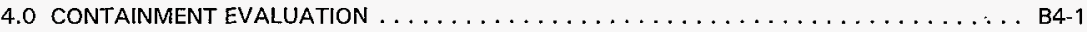

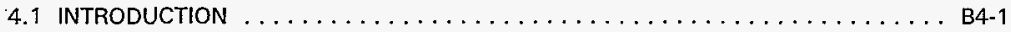

4.2 CONTAINMENT SOURCE SPECIFICATION $\ldots \ldots \ldots \ldots \ldots \ldots \ldots \ldots \ldots \ldots \ldots \ldots$ B4-1

4.3 NORMAL TRANSPORT CONDITIONS $\ldots \ldots \ldots \ldots \ldots \ldots \ldots \ldots \ldots \ldots \ldots \ldots \ldots$ B4-1

4.3.1 Conditions To Be Evaluated . . . . . . . . . . . . . . . B4-1

4.3.2 Containment Acceptance Criteria . . . . . . . . . . . . . B .

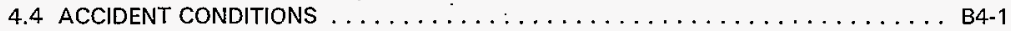

4.4.1 Conditions To Be Evaluated ................... B4-1

4.5 CONTAINMENT EVALUATION AND CONCLUSIONS $\ldots \ldots \ldots \ldots \ldots \ldots \ldots \ldots$ B4-1

4.5.1 Normal Transport Conditions . . . . . . . . . . . . . . B4-1

4.5 .2 Accident Conditions . . . . . . . . . . . . . . . . . B4-2

4.6 SUMMARY OF DOSE CONSEQUENCE RESULTS $\ldots \ldots \ldots \ldots \ldots \ldots \ldots \ldots \ldots$ B4-2

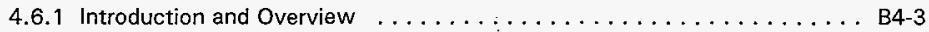

4.6.2 Dose Consequence Analysis Methodology . . . . . . . . . . . . . B4-3

4.6 .3 Source Term . . . . . . . . . . . . . . . . . . . . . B4-3

4.6.4 External Dose Due to Photon (Gamma) Exposure . . . . . . . . . . . . B4-4

4.6.5 External Dose Due to $\beta$-Particle Emitters . . . . . . . . . . . . . B4-5

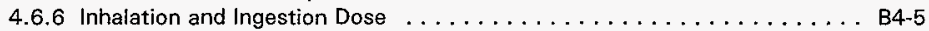

4.6.7 Skin Contamination and Ingestion Dose . . . . . . . . . . . . B4-8

4.6.8 Submersion Dose Due to Gaseous Vapor . . . . . . . . . . . . B4-9

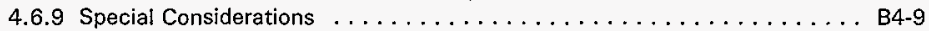

4.6.10 Total Dose . . . . . . . . . . . . . . . . . . . . . . B4-9

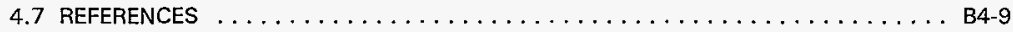

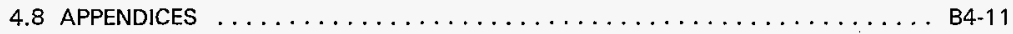

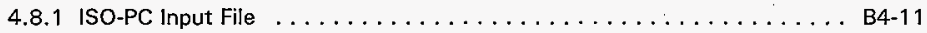

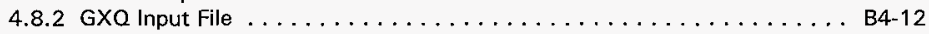

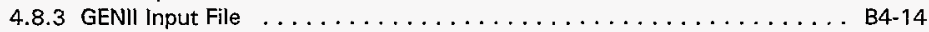

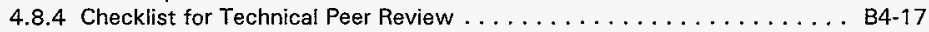

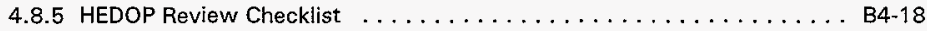

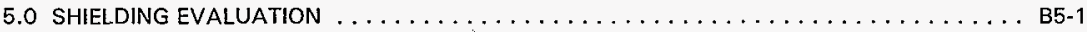

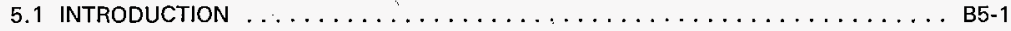

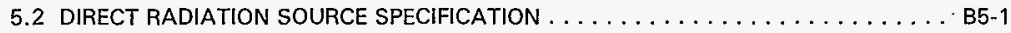

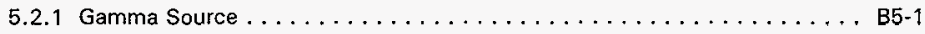

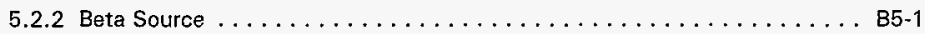

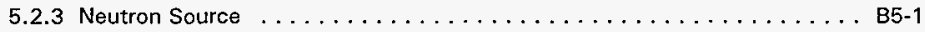




\section{CONTENTS (cont)}

5.3 SUMMARY OF SHIELIDING PROPERTIES OF MATERIALS $\ldots \ldots \ldots \ldots \ldots \ldots \ldots$ B5-2

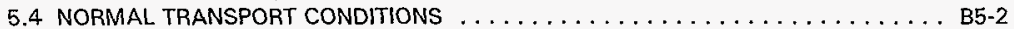

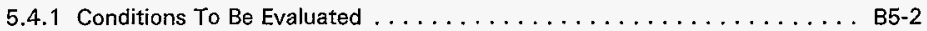

5.4 .2 Acceptance Criteria $\ldots \ldots \ldots \ldots \ldots \ldots \ldots \ldots \ldots \ldots \ldots$ B5-2

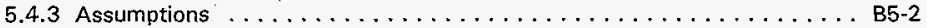

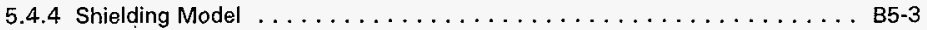

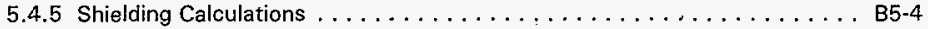

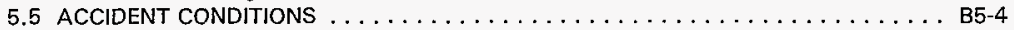

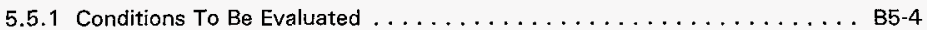

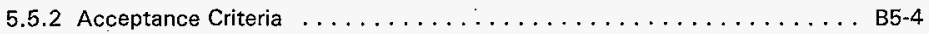

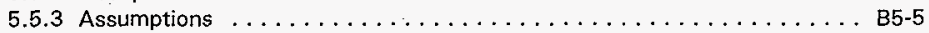

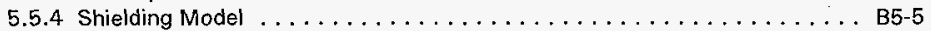

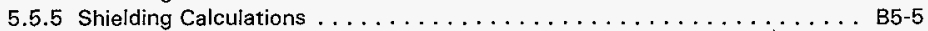

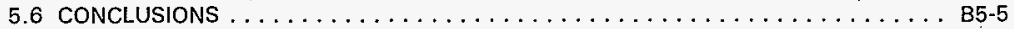

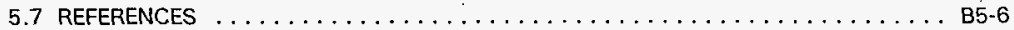

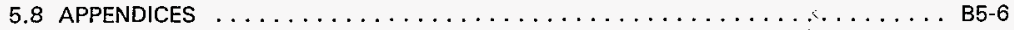

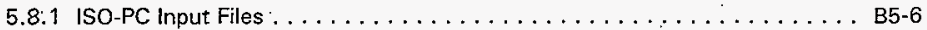

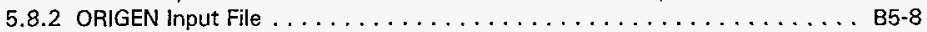

5.8 .3 Neutron Dose Calculations $\ldots \ldots \ldots \ldots \ldots \ldots \ldots \ldots \ldots \ldots$ B5-9

5.8.4 Peer Review Checklist for Shielding . . . . . . . . . . . . B5-10

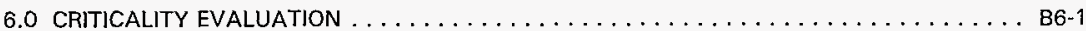

6.1 APPENDIX: CRITICALITY SAFETY ANALYSIS $\ldots \ldots \ldots \ldots \ldots \ldots \ldots \ldots \ldots$ B6-1

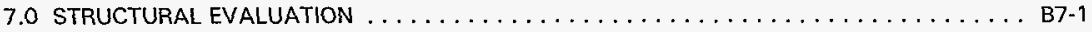

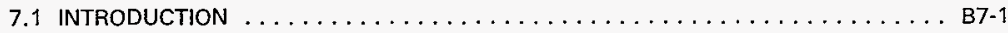

7.2 STRUCTURAL EVALUATION OF PACKAGE $\ldots \ldots \ldots \ldots \ldots \ldots \ldots \ldots \ldots \ldots \ldots \ldots \ldots$ B 1

7.2.1 Package Structural Description $\ldots \ldots \ldots \ldots \ldots \ldots \ldots \ldots \ldots \ldots \ldots \ldots$ B7-1

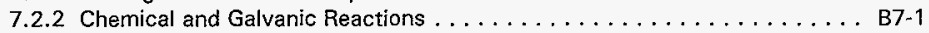

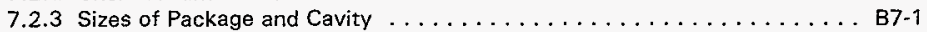

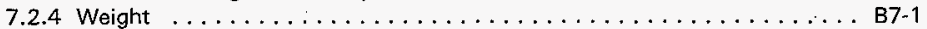

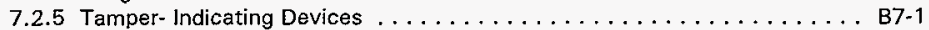

7.2 .6 Positive Closure . . . . . . . . . . . . . . . . . . . B 7.2

7.2.7 Lifting and Tiedown Devices . . . . . . . . . . . . . . . . .

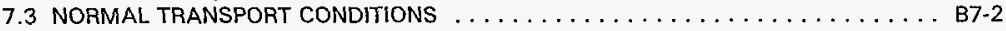

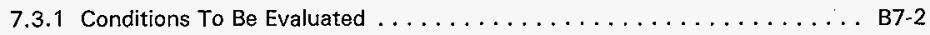

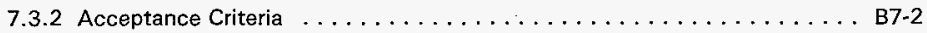

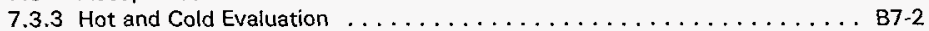

7.3.4 Reduced and Increased External Pressure $\ldots \ldots \ldots \ldots \ldots \ldots \ldots \ldots$ B7-3

7.3 .5 Vibration . . . . . . . . . . . . . . . . . . . . . . .

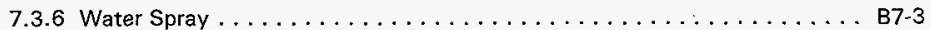

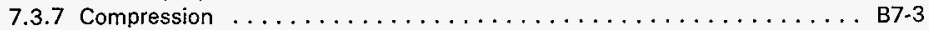

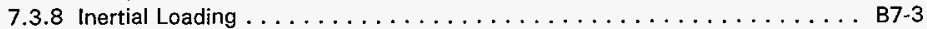

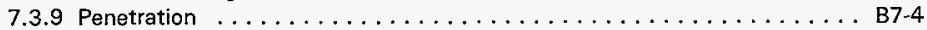

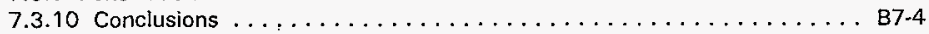

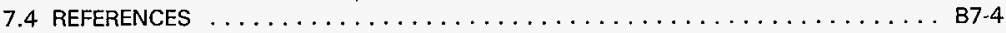

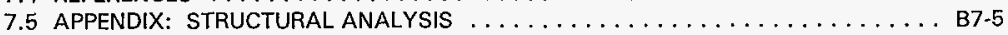

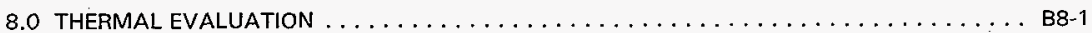

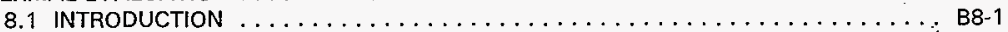

8.2 THERMAL EVALUATION OF PACKAGE $\ldots \ldots \ldots \ldots \ldots \ldots \ldots \ldots \ldots \ldots$ B8-1

8.2.1 Package Description . . . . . . . . . . . . . . . . B8-1 


\section{CONTENTS (cont)}

8.3 NORMAL TRANSPORT CONDITIONS THERḾAL EVALUATION . . . . . . . B B8-1

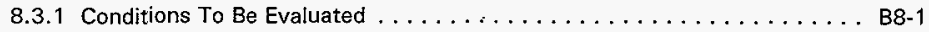

8.3.2 Acceptance Criteria . . . . . . . . . . . . . . . . . . B8-1

8.3.3 Thermal Evaluation and Conclusions . . . . . . . . . . . . B8-1

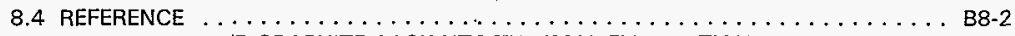

8.5 APPENDIX: PRTR GRAPHITE CASK NTC THERMAL EVALUATION . . . . . . . . B8-3

9.0 PRESSURE AND GAS GENERATION EVALUATION $\ldots \ldots \ldots \ldots \ldots \ldots \ldots \ldots \ldots$

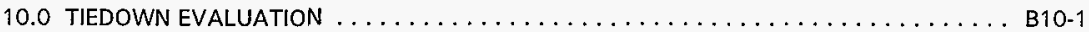

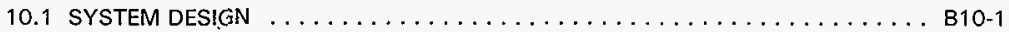

10.2 ATTACHMENTS, RATINGS, AND REQUIREMENTS $\ldots \ldots \ldots \ldots \ldots \ldots \ldots$ B10-2

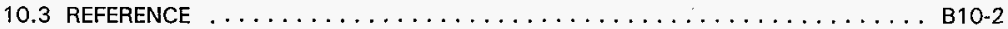

10.4 APPENDIX: ENGINEERING SAFETY EVALUATION $\ldots \ldots \ldots \ldots \ldots \ldots \ldots \ldots$ B10-3

\section{FIGURE}

B3-1 Flow Chart for Hanford Site Large Package Truck Accidents. . . . . . . . . . . . B3-5

\section{LIST OF TABLES}

A3-1 Maximum Allowable Source Term $\ldots \ldots \ldots \ldots \ldots \ldots \ldots \ldots \ldots \ldots \ldots \ldots \ldots$

A3-2 Fissile/Fissionable Material Limits in the Plutonium Recycle Test Reactor Graphite Cask . . A3-2

A3-3 Inner Container Description . . . . . . . . . . . . . . . . A3-2

A4-1 External Container Contamination Limits $\ldots \ldots \ldots \ldots \ldots \ldots \ldots \ldots \ldots \ldots \ldots \ldots$ A4-2

B2-1 Maximum Allowable Source Term $\ldots \ldots \ldots \ldots \ldots \ldots \ldots \ldots \ldots \ldots \ldots \ldots \ldots \ldots$

B2-2 Decay Heat and $A_{2}$ Calculation for the Plutonium Recycle Test Reactor Graphite Cask ... 82-1

B2-3 Fissile/Fissionable Material Limits in the Plutonium Recycle Test Reactor Graphite Cask ... B2-2

B2-4 Inner Container Description $\ldots \ldots \ldots \ldots \ldots \ldots \ldots \ldots \ldots \ldots \ldots \ldots \ldots \ldots \ldots \ldots \ldots$

B3-1 Risk Acceptance Criteria Limits $\ldots \ldots \ldots \ldots \ldots \ldots \ldots \ldots \ldots \ldots \ldots \ldots \ldots \ldots \ldots \ldots$

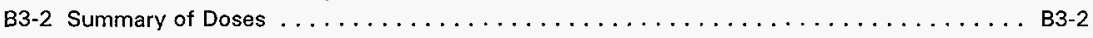

B3-3 Failure Thresholds and Conditional Release Probabilities $\ldots \ldots \ldots \ldots \ldots \ldots \ldots \ldots$

B4-1 Summary of Doses (rem) for the Plutonium Recycle Test Reactor Graphite Cask ... . . . . B4-2

B4-2 Plutonium Recycle Test Reactor Graphite Casks Radioactive Inventory . . . . . . . . B4-4 
HNF-SD-TP-SEP-063, ReV. 0

\section{LIST OF TABLES (cont)}

B4-3 $\beta$-Particle Dose Rate for Beta Emitters Contributing $>0.01 \%$ to the Total Dose $\ldots . .$. B4-5

B4-4 Accident Airborne Release Quantities, $\mathrm{Ci} \ldots \ldots \ldots \ldots \ldots \ldots \ldots \ldots \ldots$

B4-5 Inhalation and Submersion Dose $(r e m) \ldots \ldots \ldots \ldots \ldots \ldots \ldots \ldots \ldots \ldots$

B5-1 Maximum Allowable Shielding Source Term . . . . . . . . . . . . B5-1

B5-2 Neutron Source Term for $175 \mathrm{~g}$ of ${ }^{239} \mathrm{Pu} \ldots \ldots \ldots \ldots \ldots \ldots \ldots \ldots \ldots \ldots \ldots \ldots$

B5-3 Source Parameters $\ldots \ldots \ldots \ldots \ldots \ldots \ldots \ldots \ldots \ldots \ldots \ldots \ldots \ldots \ldots \ldots \ldots$

B5-4 Shielding Parameters $\ldots \ldots \ldots \ldots \ldots \ldots \ldots \ldots \ldots \ldots \ldots \ldots \ldots \ldots \ldots \ldots$

B5-5 Maximum Dose Rates Around the Plutonium Recycle Test Reactor Graphite Cask ... . . B5-4

B5-6 Maximum Dose Rates Around the Plutonium Recycle Test Reactor Graphite Cask for

Accident Conditions . . . . . . . . . . . . . . . . 


\section{LIST OF TERMS}

\begin{tabular}{|c|c|}
\hline \\
\hline \multicolumn{2}{|r|}{ American National Standards Institute } \\
\hline atm & atmosphere \\
\hline $\mathrm{Bq} / \mathrm{cm}^{2}$ & becquerels per square centimeter \\
\hline CFR & Code of Federal Regulations \\
\hline $\mathrm{Ci}$ & curie \\
\hline $\mathrm{cm}$ & centimeter \\
\hline $\mathrm{cm}^{3}$ & cubic centimeter \\
\hline DOE & U.S. Department of Energy் \\
\hline DOT & U.S. Department of Transportation \\
\hline $\mathrm{dpm} / \mathrm{cm}^{2}$ & disintegrations per minute per square centimeter \\
\hline EDE & effective dose equivalent \\
\hline FFTF & Fast Flux Test Facility \\
\hline $\mathrm{ft}$ & foot \\
\hline $\mathrm{ft} / \mathrm{s}^{2}$ & feet per second squared \\
\hline g & gram \\
\hline $\mathrm{g} / \mathrm{cm}^{3}$ & grams per cubic centimeter \\
\hline Gy & gray \\
\hline Gy/h & gray per hour \\
\hline $\mathrm{Hz}$ & hertz \\
\hline IAEA & International Atomic Energy Agency \\
\hline in. & inch \\
\hline $\mathrm{kg}$ & kilogram \\
\hline $\mathrm{km}$ & kilometer \\
\hline $\mathrm{km} / \mathrm{h}$ & kilometers per hour \\
\hline $\mathrm{kPa}$ & kilopascal \\
\hline $\mathrm{lb}$ & pound \\
\hline$\mu \mathrm{Ci} / \mathrm{cm}^{2}$ & microcuries per square centimeter \\
\hline MAP & mixed activation products \\
\hline $\mathrm{MeV}$ & megaelectronvolt \\
\hline MFP & mixed fission products \\
\hline mi & mile \\
\hline $\mathrm{mi} / \mathrm{h}$ & miles per hour \\
\hline $\mathrm{MPa}$ & megapascal \\
\hline $\mathrm{mrem} / \mathrm{h}$ & millirem per hour \\
\hline $\mathrm{m} / \mathrm{s}^{2}$ & meters per second squared \\
\hline $\mathrm{mSv} / \mathrm{h}$ & millisievert per hour \\
\hline $\mathrm{N}$ & newton \\
\hline non-HRCO & non-highway route controlled quantity \\
\hline NTC & normal transport conditions \\
\hline PCF & probability of release from crush failure \\
\hline PIF & probability of release from impact failure \\
\hline PFF & probability of release from fire failure \\
\hline PNC & Power Reactor and Nuclear Fuel Development Corporation \\
\hline PPF & probability of release from puncture failure \\
\hline PRTR & Plutonium Recycle Test Reactor \\
\hline psi & pounds per square inch \\
\hline QA & quality assurance \\
\hline OL & quality leve! \\
\hline RF & respirable fraction \\
\hline SEP & safety evaluation for packaging \\
\hline SERF & Special Environmental Radiometallurgy Facility \\
\hline Sv & sievert \\
\hline
\end{tabular}


HNF-SD-TP-SEP-063, Rev. 0

\section{LIST OF TERMS (cont)}

Sv/h

TBq

THI

W

W/Ci sievert per hour

terabecquerel

Transportation Hazard Index

watt

watts per curie 


\section{SAFETY EVALUATION FOR PACKAGING (ONSITE) PLUTONIUM RECYCLE TEST REACTOR GRAPHITE CASK}

\section{PART A: DESCRIPTION AND OPERATIONS}

\subsection{INTRODUCTION}

\subsection{GENERAL INFORMATION}

The Plutonium Recycle Test Reactor (PRTR) Graphite Cask is used by B\&W Hanford Company to transport radioactive materiais among the $323,324,325,326,327$, and 3270 Buildings. The radioactive materials most frequently transported among buildings are mixed oxide fuel, metal oxide fuel, and activated structural materials from reactors. The cask will be used to transport Type B, fissile, non-highway route controlled quantities of radioactive materials within the 300 Area of the Hanford Site.

This safety evaluation for packaging (SEP) provides the evaluation necessary to demonstrate that the PRTR Graphite Cask meets the requirements for onsite transportation of a Type B package. The packaging meets all WHC-CM-2-14, Hazardous Material Packaging and Shipping, requirements for the Hanford Site. The scope of this SEP includes risk, shielding, criticality, and tiedown analyses to demonstrate that onsite transportation safety requirements are satisfied. This SEP also establishes operational and maintenance guidelines to ensure that transport is performed safely in accordance with WHC-CM-2-14.

\subsection{SYSTEM DESCRIPTION}

The cask is a horizontal, cylindrical, stainless steel transfer cask with $13.7 \mathrm{~cm}$ (5.38 in.) of lead shielding. The outside diameter is $35.6 \mathrm{~cm}(14.0 \mathrm{in})$ ), and the length is $99.0 \mathrm{~cm}(39.0 \mathrm{in}$.$) . The interior$ cavity is $7.9 \mathrm{~cm}$ ( $3.1 \mathrm{in.})$ in diameter and $63.5 \mathrm{~cm}(25.0 \mathrm{in.})$ long. The empty weight of the cask is $1,089 \mathrm{~kg}(2,400 \mathrm{lb})$, and the maximum gross weight of the cask is $1,202 \mathrm{~kg}(2,650 \mathrm{lb})$.

\subsection{REVIEW AND UPDATE CYCLES}

This SEP is valid until October 1, 1999. An update or upgrade to this document is required beyond that date. 
HNF-SD-TP-SEP-063, Rev. 0

This page left intentionally blank.

A1-2 


\subsection{PACKAGING SYSTEM}

\subsection{CONFIGURATION AND DIMENSIONS}

The PRTR Graphite Cask is fundamentally a right circular cylinder of lead and stainless steel composite construction. The lead is sandwiched between outer and inner stainless steel tubular shells. At each end of the cask is a thick circular plate that is welded to both inner and outer shells, which encapsulates the lead. At the top, closure of the inner cavity is provided by a bolted blind flange with an attached shield plug of composite lead-stainless steel construction. The cask is equipped with a manually actuated, rotating, shielded drum door, which provides closure at the bottom end. None of the end closures are sealed. A handling yoke is provided on the cask and welded to the outer shell. Attached to the yoke is a lifting bail, which can be locked into position for lifting and handling of the cask. Support plates are welded to the outer bottom housing to provide support during transport.

The cask is $35.6 \mathrm{~cm}(14.0 \mathrm{in}$ ) in diameter and $99.0 \mathrm{~cm}(39.0 \mathrm{in}$.$) in length. Dimensions of the$ inner cavity are $7.95 \mathrm{~cm}(3.13 \mathrm{in.})$ in diameter by $63.5 \mathrm{~cm}(25.0 \mathrm{in.})$ in length. Lead between the outer and inner shelis provides shielding.

\subsection{MATERIALS OF CONSTRUCTION}

All structural components are constructed of 304 stainless steel. Lead is used for shielding.

\subsection{WEIGHTS AND CENTER OF GRAVITY}

The empty weight of the cask is $1,089 \mathrm{~kg}(2,400 \mathrm{lb})$. The maximum weight with contents is $1,202 \mathrm{~kg}(2,650 \mathrm{lb})$. The center of gravity of the PRTR Graphite Cask is approximately the geometric center of the cask.

\subsection{CONTAINMENT BOUNDARY}

The containment system consists of the inner container. The cask retains the contents, but is not considered to be a containment boundary. No credit is taken for containment provided by the cask.

\subsection{CAVITY SIZE}

The available space within the cask consists of a cylindrical volume $7.9 \mathrm{~cm}$ ( $3.1 \mathrm{in.}$ ) in diameter and $63.5 \mathrm{~cm}(25.0 \mathrm{in}$.$) in length.$

\subsection{SHIELDING}

The interior of the cask is lined with lead shielding, which is $13.7 \mathrm{~cm}(5.38 \mathrm{in.})$ thick.

\subsection{LIFTING DEVICES}

The lifting device consists of two support arms attached to a lifting yoke. Each support arm is secured to the yoke by three $5 / 8$ in.-11 stainless steel cap screws and is secured to the cask shell by a $1 / 2$ in.-13 stainless steel cap screw. The lifting assembly is positionable and is equipped with a locking device. 
HNF-SD-TP-SEP-063, Rev. 0

\subsection{TIEDOWN DEVICES}

There are no tiedown devices attached to the cask. 
HNF-SD-TP-SEP-063, Rev. 0

\subsection{PACKAGE CONTENTS}

\subsection{GENERAL DESCRIPTION}

Materiais to be transported in the PRTR Graphite Cask include irradiated structural materials and solid pieces of irradiated fuel containing uranium and plutonium isotopes.

\subsection{CONTENTS RESTRICTIONS}

The materials specified in this section are the only materials authorized for shipment in the PRTR Graphite Cask within the 300 Area of the Hanford Site. Contact dose rates shall be less than $2.0 \mathrm{mSv} / \mathrm{h}(200 \mathrm{mrem} / \mathrm{h})$. Gas-generating materials shall not be loaded into the cask. Absorbed and unabsorbed liquids are not authorized for shipment in the cask. Organic materials are not authorized except plastic bags/wrapping.

\subsubsection{Radioactive Materials}

The cask will transport Type $B$, fissile, non-highway route controlled quantities of radioactive materials. Table A3-1 gives the radioactive contents limits for the cask. Fissile limitations are given in Table A3-2 for shipments of fissionable material scrap of various compositions. The source term limits in Table A3-1 are a result of the limited shielding ability of the cask as described in Part B, Section 5.0.

Table A3-1. Maximum Allowable Source Term.

\begin{tabular}{|l|c|c|}
\hline \multirow{2}{*}{\multicolumn{2}{|c|}{ Material }} & \multicolumn{2}{c|}{ Activity limit } \\
\cline { 2 - 3 } & TBq & Ci \\
\hline Fissile materials and $\alpha$ emitters $*$ & 0.401 & 10.9 \\
\hline Mixed fission products & 13.9 & 375 \\
\hline Mixed activation products & 0.185 & 5.00 \\
\hline
\end{tabular}

*Fissile/fissionable materials limited by criticality safety as shown in Part B, Section 2.1.1.

Contents to be transported in the PRTR Graphite Cask shall consist of small pieces or test samples of irradiated fuel pieces and various activated materials. The contents shall be limited to the maximum allowable source term as shown in Table A3-1. The cask may also be used to transport metallographic samples and waste from the 327 Facility examination process.

All materials shall be enclosed in an inner container to prevent the spread of removable contamination. Table A3-3 provides a description of authorized inner containers and their contents.

\subsubsection{Nonradioactive Hazardous Materials}

No nonradioactive hazardous materials can be shipped in the PRTR Graphite Cask. 
Table A3-2. Fissile/Fissionable Material Limits in the Plutonium Recycle Test Reactor Graphite Cask.

\begin{tabular}{|c|c|}
\hline Material & Limit \\
\hline${ }^{235} \mathrm{U}$ & $275 \mathrm{~g}^{*}$ or \\
\hline $\begin{array}{l}{ }^{239} \mathrm{Pu},{ }^{233} \mathrm{U},{ }^{237} \mathrm{~Np},{ }^{241} \mathrm{Am}, \\
{ }^{243} \mathrm{Am},{ }^{244} \mathrm{Cm} \text {, and }{ }^{247} \mathrm{Cm}\end{array}$ & $175 \mathrm{~g}$ aggregate total ${ }^{*}$ \\
\hline${ }^{242 \mathrm{~m}} \mathrm{Am},{ }^{243} \mathrm{Cm},{ }^{245} \mathrm{Cm},{ }^{249} \mathrm{Cf}$, or & $\begin{array}{l}\text { Not analyzed and cannot be shipped in excess } \\
\text { of safeguards accountability limits* }\end{array}$ \\
\hline
\end{tabular}

Source: Larson, S. L., 1996, Limits for Fissionable Material in Small Bore Transfer Casks and Lead Pigs (NCS Basis Memo 96-2 to M. Dec, December 30), Battelle Pacific Northwest Laboratories, Richland, Washington.

* Mixtures of fissionable material are possible provided that the sum-offractions method shown in PNL (1994) and referenced in Larson (1996), attached in Part B, Section 6.0, are followed.

PNL, 1994, Criticality Safety, PNL-MA-25, Battelle Pacific Northwest Laboratories, Richland, Washington.

Table A3-3. Inner Container Description.

\begin{tabular}{|l|l|l|}
\hline \multicolumn{1}{|c|}{ Inner container } & \multicolumn{1}{|c|}{ Contents } & \multicolumn{1}{c|}{ Examples of contents } \\
\hline $\begin{array}{l}\text { Pin tubes--tubes and fittings must have } \\
\text { a working rating of } 20.68 \mathrm{MPa} \\
(3000 \mathrm{psi}), \text { with an outer diameter of } \\
1.3 \mathrm{~cm}(0.50 \mathrm{in.}) \text { or } 1.9 \mathrm{~cm} 10.75 \mathrm{in.}) . \\
\begin{array}{l}\text { The tubes are welded on one end. A } \\
\text { Swagelok* fitting is used as closure. }\end{array}\end{array}$ & Dispersible solid materials & $\begin{array}{l}\text { Irradiated structural materials; solid } \\
\text { pieces of irradiated FFTF, PNC, and } \\
\text { N Reactor fuel pins; and small pieces } \\
\text { or test samples of irradiated fuel and } \\
\text { structural materials }\end{array}$ \\
\hline $\begin{array}{l}\text { DOT Specification 2R per } 49 \mathrm{CFR} \\
178.360\end{array}$ & Dispersible solid materials & $\begin{array}{l}\text { Irradiated structural materials; solid } \\
\text { pieces of irradiated FFTF, PNC, and } \\
\text { N Reactor fuel pins; and small pieces } \\
\text { or test samples of irradiated fuel and } \\
\text { structural materials in glass or plastic } \\
\text { vials with screw cap }\end{array}$ \\
\hline $\begin{array}{l}\text { Large solid item put directly into the } \\
\text { cask }\end{array}$ & $\begin{array}{l}\text { Nondispersible solid } \\
\text { structural material and } \\
\text { activated metals put } \\
\text { directly into the cask* }\end{array}$ & $\begin{array}{l}\text { Large solid items with fixed surface } \\
\text { contamination }\end{array}$ \\
\hline
\end{tabular}

DOT $=$ U.S. Department of Transportation.

FFTF = Fast Flux Test Facility .

PNC $=$ Power Reactor and Nuclear Fuel Development Corporation.

* Swagelok is a trademark of the Crawford Fitting Company.

* * Surface contamination limits not to exceed 100 times the Table A4-1 limits. Verification by survey or the use of a fixative, such as paint, is required.

49 CFR 178, 1997, "Specifications for Packagings," Code of Federal Regulations, as amended. 


\subsection{TRANSPORT SYSTEM}

\subsection{TRANSPORTER}

The transporter consists of a low boy or flatbed trailer and tractor. The trailer shall be rated for the weight of the loaded cask and have a large enough bed to prevent the cask from protruding over the edges of the trailer.

\subsection{TIEDOWN SYSTEM}

The cask shall be centered and placed horizontally on the bed of the trailer for shipment. The long axis of the cask shall be centered along the long axis of the trailer.

The package is to be secured in accordance with U.S. Department of Transportation regulations ( 49 CFR 393.100). The cask is to be secured to the trailer by two sets of tiedowns as shown in Figure 4-1. One set acts as chocks to block and brace the cask from horizontal movement. The other set acts as vertical restraints. There are two $4 \times 4$ wood blocks placed at each end of the cask. These $4 \times 4$ blocks have a $2 \times 2$ nailed to the side at the bottom to form landings for the tiedowns. Each of the chocking tiedowns is looped around the cask from opposite sides of the trailer and attached to the trailer. The chocking tiedowns lay on the landing and bear against the wood blocks when drawn tight. The vertical restraint tiedowns are placed over the cask on each side of the lifting yoke. These tiedowns are then attached to the trailer on opposite sides and drawn tight.

Figure 4-1. Cask Tiedown Configuration.

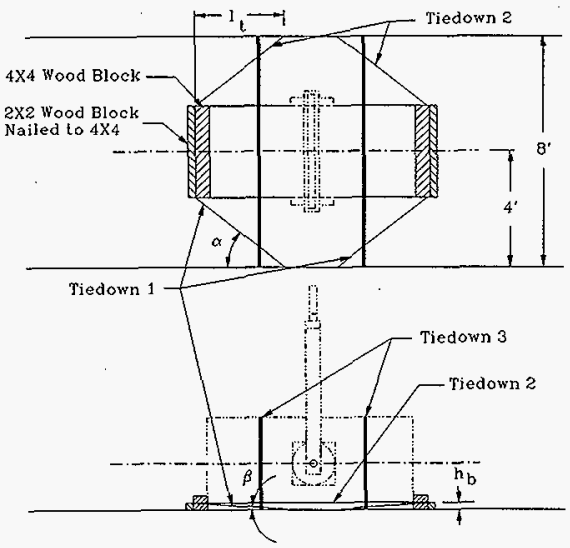

Nole:Tiedowns 1 \&2 go oround cask

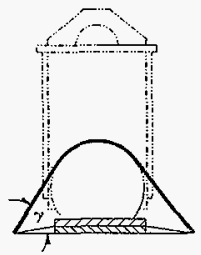


HNF-SD-TP-SEP-063, Rev, 0

Each tiedown and trailer attachment point must have a minimum working strength of $11,120 \mathrm{~N}$ $(2,500 \mathrm{lb})$. The $2 \times 2$ wood blocks must be nailed to the $4 \times 4$ wood blocks with a minimum of three $10 \mathrm{~d}$ nails. The length of the blocks is specified as the same as the diameter of the cask to within a tolerance of $0.32 \mathrm{~cm} \mathrm{(1/8} \mathrm{in.).}$

Alternative configurations that have been shown to meet 49 CFR 393 , Subpart 1, are acceptable.

\subsection{SPECIAL. TRANSPORT REQUIREMENTS}

\subsubsection{Routing and Access Control}

The PRTR Graphite Cask is authorized for onsite transport only within the 300 Area. Transfers shall be made in accordance with WHC-CM-2-14 over a predetermined route.

\subsubsection{Radiological Limitations}

The dose rate must be less than $2 \mathrm{mSv} / \mathrm{h}(200 \mathrm{mrem} / \mathrm{h})$ at the surface of the cask, $0.1 \mathrm{mSv} / \mathrm{h}$ $(10 \mathrm{mrem} / \mathrm{h})$ at $1 \mathrm{~m}$ from the cask surface, and $0.02 \mathrm{mSv} / \mathrm{h}(2 \mathrm{mrem} / \mathrm{h})$ in any normally occupied space. Transport of the PRTR Graphite Cask above these limits is not authorized. The shielding analysis in Part B, Section 5.0, shows the projected dose rates meet these limits for the authorized source term. Table A4-1.

External contamination limits for the exterior of the PRTR Graphite Cask are as shown in

Table A4-1. External Container Contamination Limits.

\begin{tabular}{|l|c|c|c|}
\hline \multirow{2}{*}{ Contaminant } & \multicolumn{3}{c|}{ Maximum permissible limits } \\
\cline { 2 - 4 } & $\mathrm{Bq} / \mathrm{cm}^{2}$ & $\mu \mathrm{Ci} / \mathrm{cm}^{2}$ & $\mathrm{dpm} / \mathrm{cm}^{2}$ \\
\hline $\begin{array}{l}\text { Beta and gamma emitters and low toxicity alpha } \\
\text { emitters }\end{array}$ & 0.4 & $10^{-5}$ & 22 \\
\hline All other alpha-emitting radionuclides & 0.04 & $10^{-6}$ & 2.2 \\
\hline
\end{tabular}

Source: 49 CFR 173.443, 1995, "Shippers--General Requirements for Shipments and Packagings," Code of Federal Regulations, as amended.

\subsubsection{Speed Limitations}

The PRTR Graphite Cask shall not exceed a speed of $8 \mathrm{~km} / \mathrm{h}(5 \mathrm{mi} / \mathrm{h})$ during transport.

\subsubsection{Environmental Conditions}

In order to reduce the possibility of an accident, there shall be no transfers at temperatures below $0^{\circ} \mathrm{C}\left(32^{\circ} \mathrm{F}\right)$ or during periods of dense fog or adverse road conditions (such as snow or ice). 


\subsubsection{Frequency of Use and Mileage Limitations}

A risk analysis was performed on the 327 Building casks to determine mileage limitations. The results of the evaluation have determined that transfers shall not exceed a total of $16.0 \mathrm{~km}(10.0 \mathrm{mi})$ per year for the 327 Building family of casks, which includes the Special Environmental

Radiometallurgy Facility Cask, the Radioactive Waste Disposal Cask, and the PRTR Graphite Cask. This limit allows up to 40 transfers of $0.40 \mathrm{~km}(0.25 \mathrm{mi})$ per year. This limit does not apply to empty cask shipments.

\subsubsection{Emergency Response}

Emergency responders shall be notified prior to transfers of the cask. The shipping and receiving facilities, Radiation Protection, Safety, Packaging Engineering, and Transportation Logistics shall be notified of all accidents involving radioactive material shipment that result in vehicle damage, container damage, personnel injury, or contamination spread. 
HNF-SD-TP-SEP-063, Rev. 0

This page intentionally left blank. 


\subsection{ACCEPTANCE OF PACKAGING FOR USE}

\subsection{NEW PACKAGING}

The PRTR Graphite Cask was originally accepted for use in the 1960 s. That acceptance is documented in Hazardous Materials Packaging and Shipping Manual (HEDL 1987). The cask has been used for shipments within the 300 Area for approximately 20 years without incident. The PRTR Graphite Cask has a frequency of use of approximately six transfers per year. No new casks will be manufactured, so new packaging acceptance requirements do not apply.

\subsection{PACKAGING FOR REUSE}

In order to continue using the PRTR Graphite Cask, the maintenance and operating plans must be followed. A visual inspection for physical damage and corrosion on the cask and a check of the closing mechanism for proper operation shall occur prior to reuse. These inspections shall be documented in accordance with facility operating procedures.

If required, the cask shall be decontaminated prior to use to meet external contamination limits per Table A4-1. 
HNF-SD-TP-SEP-063, ReV. 0

This page left intentionally blank.

A5-2 
HNF-SD-TP-SEP-063, Rev. 0

\subsection{OPERATING REQUIREMENTS}

\subsection{GENERAL REQUIREMENTS}

The following are requirements for the use of the PRTR Graphite Cask. Prior to loading and shipment of the cask, specific operating procedures with appropriate Quality Assurance/Quality Control hold points shall be written by the user and approved per WHC-CM-2-14. The procedures shall implement the requirements of this section and the additional requirements found in this SEP.

For loading and unloading operations, the following general requirements shall be performed.

1. Visually inspect the PRTR Graphite Cask for cracks or damage.

2. Visually inspect the lifting attachments for cracks and damage.

3. Verify that radiological contamination limits are within the allowable limits shown in Table A4-1 of this SEP.

4. Verify radiological dose rates are acceptable prior to shipment of the cask in accordance with Part A, Section 4.3.2, of this SEP. The dose rate limits are $2 \mathrm{mSv} / \mathrm{h}$ $(200 \mathrm{mrem} / \mathrm{h})$ on any surface of the cask, $0.1 \mathrm{mSv} / \mathrm{h}(10 \mathrm{mrem} / \mathrm{h})$ at $1 \mathrm{~m}$ from the cask, and $0.02 \mathrm{mSv} / \mathrm{h}(2 \mathrm{mrem} / \mathrm{h})$ in any normally occupied space.

5. Verify that the number of transfers or mileage shipped in a year has not exceeded the amount established by the risk assessment (40 shipments of approximately $0.40 \mathrm{~km}$ [0.25 mi] each or $16.0 \mathrm{~km}$ [10.0 mi] per year).

\subsection{LOADING OF CONTENTS INTO THE CASK}

\subsubsection{Inner Container Loading}

1. Prior to loading contents, visually inspect the inner container to be used.

2. If vials are to be used, visually inspect them for damage.

3. Place cushioning material in the inner container to protect glass vials. Multiple vials may be placed in the inner container. Plastic vials may be packaged as glass vials.

4. After placing the vials in the inner container, fill the void spaces with cushioning material.

5. Close the inner container.

\subsubsection{Preparing the Cask for Loading}

1. Verify that the contents to be loaded into the cask are as authorized in Part A, Section 3.0, of this SEP and that criticality limits have not been exceeded.

2. Verify that the cask is positioned properly at the cell loading port and is ready to receive the contents. Open the cell loading port. 
HNF-SD-TP-SEP-063, Rev. 0

\subsubsection{Loading Contents into the Cask}

1. Attach the push/pull rod to the rear end of the cask scoop fixture, commonly called the cask boat.

2. Release the locking mechanism and rotate the closure valve $90^{\circ}$.

3. Release the locking pin holding the boat and push the boat into the cell to the desired position.

4. Load the materials onto the boat and pull the boat back into the cask. Secure the locking pin.

5. Rotate the closure valve $90^{\circ}$ and secure the locking mechanism.

6. Close the cell loading port and move the cask away from the cell.

7. Perform radiological dose and contamination surveys to verify levels have not exceeded the limits authorized in Part A, Section 4.0, of this SEP. Decontaminate if contamination limits are exceeded. Do not ship if radiological dose has exceeded $2 \mathrm{mSv} / \mathrm{h}(200 \mathrm{mrem} / \mathrm{h})$ on the surface of the cask, $0.1 \mathrm{mSv} / \mathrm{h}(10 \mathrm{mrem} / \mathrm{h})$ at $1 \mathrm{~m}$ from the cask, and $0.02 \mathrm{mSv} / \mathrm{h}(2 \mathrm{mrem} / \mathrm{h})$ in any normally occupied space.

8. Following radiological survey, wrap the ends of the cask with 10-mil plastic and tape to the cask body using duct tape.

\subsection{PREPARATION OF THE CASK FOR SHIPMENT}

1. Verify that the shipping papers have been prepared properly and the cask is properly marked and labeled per the requirements of WHC-CM-2-14.

2. Position the transport vehicle where it will be accessible to the overhead crane.

3. Verify the lifting equipment is in accordance with the Hanford Site Hoisting and Rigging Manual, DOE/RL-92-36 (RL 1996).

4. Attach the lifting equipment to the cask lifting attachment and the crane hook.

5. Lift the cask from the floor to allow a radiological survey of the cask to be performed.

6. Move the cask over the vehicle and slowly lower it into position on the transport vehicle.

7. Unhook the lifting equipment from the cask and install tiedown attachments per the requirements of Part A, Section 4.2.

8. Prior to transport, verify that the shipping documentation has been completed per WHC-CM-2-14 and signed by a trained Hazardous Material Shipper. 
HNF-SD-TP-SEP-063, Rev. 0

\subsection{UNLOADING THE CASK}

1. Position the transport vehicle where it will be accessible to the overhead crane.

2. Perform radiological contamination and dose surveys of the cask to verify that the limits in Part A, Section 4.0, have not been exceeded.

3. Remove the tiedown equipment from the cask and transport vehicle.

4. Attach the lifting equipment to the cask lifting attachment and the crane hook.

5. Lift the cask off of the transport vehicle and move to a designated location. Remove the plastic from the ends of the cask.

6. Perform a radiological contamination survey of the cask ends to verify the contamination limits have not been exceeded.

7. Position the cask at the cell loading port and remove the rigging equipment from the cask.

8. Open the cell loading port.

9. Attach the push/pull rod to the rear end of the cask scoop fixture, commonly called the cask boat.

10. Release the closure valve locking mechanism and rotate the closure valve $90^{\circ}$.

11. Release the locking pin holding the boat and push the boat into the cell to the desired position.

12. Unload the materials from the boat and pull the boat back into the cask. Secure the locking pin.

13. Rotate the closure valve and secure the locking mechanism.

14. Close the cell loading port and move the cask away from the cell.

15. Perform radiological dose and contamination surveys to verify levels have not exceeded limits authorized in Part A, Section 4.0, of this SEP. Decontaminate if contamination limits are exceeded.

\subsection{EMPTY PACKAGING}

To be transported as an empty radioactive container, the cask must be prepared for transport in accordance with 49 CFR 173.428 (1995 version). 
HNF-SD-TP-SEP-063, Rev. 0

This page left intentionally blank. 


\subsection{QUALITY ASSURANCE REQUIREMENTS}

\subsection{INTRODUCTION}

This section describes the quality assurance (QA) requirements for operation of the PRTR Graphite Cask. The packaging was fabricated in the 1960 s following a quality program in effect at the time. The PRTR Graphite Cask is used to perform onsite shipments at the Hanford Site. The format and requirements for the use of the PRTR Graphite Cask on the Hanford Site are in accordance with WHC-CM-4-2, Quality Assurance Manual, and WHC-CM-2-14.

\subsection{GENERAL REQUIREMENTS}

These requirements apply to activities, which include loading, unloading, and transportation operations, that could affect the quality of the packaging and associated hardware. The overall packaging is classified per WHC-CM-2-14 as a Transportation Hazard Index (THI) 1.

THI 1 packaging systems, defined in WHC-CM-2-14, represent the highest level of hazard for the contents. A packaging system assigned this level has the potential of causing a dose consequence to an individual in excess of $25 \mathrm{rem}$ at the Hanford Site boundary if fully released.

Each THI invokes a quality level (OL) designator (defined in WHC-CM-2-14) consisting of two parts: an alpha designator and a numerical designator. The alpha designator assigns the fabrication, testing, use, maintenance standards, and quality requirements for each component of the packaging system. The numeric designator following the letter is the THI number of the packaging system. Because the PRTR Graphite Cask ships a Type B quantity of material with potentially high hazards, the package as a whole is assigned a $\mathrm{QL}$ designator of $\mathrm{A}-1$.

Documentation and review requirements are based upon the $\mathrm{OL}$ of the package. Changes or discoveries of noncompliance for all $Q \mathrm{~L}$ A-1 components and activities shall be reviewed by the unreviewed safety question screening process to ensure the quality and safety of the change or discovery. Changes to the SEP safety bases (contents, shielding, structural, containment, criticality) will require unreviewed safety question screening regardless of $\mathrm{OL}$.

\subsection{ORGANIZATION}

The organizational structure and the assignment of responsibility shall be such that quality is achieved and maintained by those who have been assigned responsibility for performing the work. Quality achievement is to be verified by persons or organizations not directly responsible for performing the work.

Packaging Engineering and the onsite user are responsible for the quality of the work performed by their respective organizations and for performing the following activities:

- Follow the current requirements of this SEP, WHC-CM-4-2, and WHC-CM-2-14

- Provide instructions for implementing QA requirements.

The cognizant manager, Quality Assurance, is responsible for establishing and administering the Hanford QA program as stated in WHC-CM-4-2. 


\subsection{QA PLAN AND ACTIVITIES}

\subsubsection{Design Control}

Design control is not applicable. This cask was fabricated over 30 years ago, and no design changes will be made. B\&W Hanford Company is the design authority for the package.

\subsubsection{Procurement and Fabrication Control}

Procurement and fabrication control is not applicable. This package is over 30 years old, and no casks will be procured in the future.

\subsubsection{Control of Operations/Processes}

Loading/unloading procedures written by the user will be used to ensure acceptable operation of the packaging. Those loading/unloading procedures shall be consistent with this SEP. The loading/unloading procedures identify actions required by personnel to safely and properly load and unload the packaging in accordance with this SEP.

Quality Control inspection checklists are established to ensure that final inspection verifies compliance with the following items.

- The PRTR Graphite Cask is properly assembled.

- All acceptance criteria (Part A, Section 5.0) are met for use of the package.

- Operational (Part A, Section 6.0) and maintenance procedures (Part A, Section 8.0) are properly completed.

\subsubsection{Control of Inspection}

Control of inspection and testing will be accomplished by facility procedures incorporating the requirements of Part $A$, Section 7.4.3.

\subsubsection{Test Control}

Test control is not applicable. No testing is required on this package.

\subsubsection{Control of Measuring and Test Equipment}

Any measuring equipment that is used shall meet the accuracy and calibration requirements as required by WHC-CM-4-2; i.e., radiation survey equipment.

\subsubsection{Control of Nonconforming Items}

Identification, documentation, evaluation, and disposition of nonconforming items and activities. shall be accomplished per WHC-CM-4-2, regardless of the assigned QL. 


\subsubsection{Corrective Action}

Nonconformance, or conditions adverse to quality, are evaluated as described in Part $A$, Section 7.4.8, and the need for corrective action is determined in accordance with WHC-CM-4-2.

\subsubsection{QA Records and Document Control}

Records that furnish documentary evidence of quality shall be specified, prepared, and maintained per WHC-CM-4-2. This includes all procedures, inspection reports, the SEP, and any nonconformance reports that are developed while this cask is used.

\subsubsection{Audits}

Internal and external independent assessments are performed in accordance with WHC-CM-4-2. 
HNF-SD-TP-SEP-063, Rev. 0

This page left intentionally blank. 


\subsection{MAINTENANCE}

\subsection{GENERAL REQUIREMENTS}

The 327 Facility shall provide the procedures for the required maintenance and inspections of the PRTR Graphite .Cask.

\subsection{INSPECTION AND VERIFICATION SCHEDULES}

The PRTR Graphite Cask shall undergo a user inspection every two years. Inspections shall be performed using the Radioactive Material Shipping Container User Biennial Inspection Checklist (Part A, Section 10.2). Nondestructive testing of the welds on the lifting apparatus shall be performed every five years using the Radioactive Material Shipping Container NDT of Lifting Apparatus (5 Year) (Part A, Section 10.2).

\subsection{RECORDS AND DOCUMENTATION}

The maintenance records shall be maintained for the length of time the PRTR Graphite Cask is owned, plus one year. The inspection records of the PRTR Graphite Cask shall be maintained until the next inspection of the same type is successfully completed. 
HNF-SD-TP-SEP-063, Rev. 0

This page left intentionally blank.

A8-2 
HNF-SD-TP-SEP-063, Rev. 0

\subsection{REFERENCES}

49 CFR 173, 1995, "Shippers--General Requirements for Shipments and Packagings," Code of Federal Regulations, as amended.

49 CFR 178, 1997, "Specifications for Packagings," Code of Federal Regulations, as amended.

49 CFR 393, 1997, "Parts and Accessories Necessary for Safe Operation," Code of Federal Regulations, as amended.

HEDL, 1987, Hazardous Materials Packaging and Shipping Manual, MG-137, Rev. 10, Hanford Engineering Development Laboratory, Richland, Washington.

Larson, S. L., 1996, Limits for Fissionable Material in Small Bore Transfer Casks and Lead Pigs (NCS Basis Memo 96-2 to M. Dec, December 30), Battelle Pacific Northwest Laboratories, Richland, Washington.

PNL, 1994, Criticality Safety, PNL-MA-25, Battelle Pacifjc Northwest Laboratories, Richland, Washington.

RL, 1996, Hanford Site Hoisting and Rigging Manual, DOE/RL-92-36, U.S. Department of Energy, Richland Operations Office, Richland, Washington.

WHC-CM-2-14, Hazardous Material Packaging and Shipping, Westinghouse Hanford Company, Richland, Washington.

WHC-CM-4-2, Quality Assurance Manual, Westinghouse Hanford Company, Richland, Washington. 
HNF-SD-TP-SEP-063, Rev. 0

This page left intentionally blank. 
HNF-SD-TP-SEP-063, Rev. 0

\subsection{APPENDICES}

10.1 DRAWINGS

A10-1 
HNF-SD-TP-SEP-063, Rev. 0

This page intentionally left blank.

A10-2 


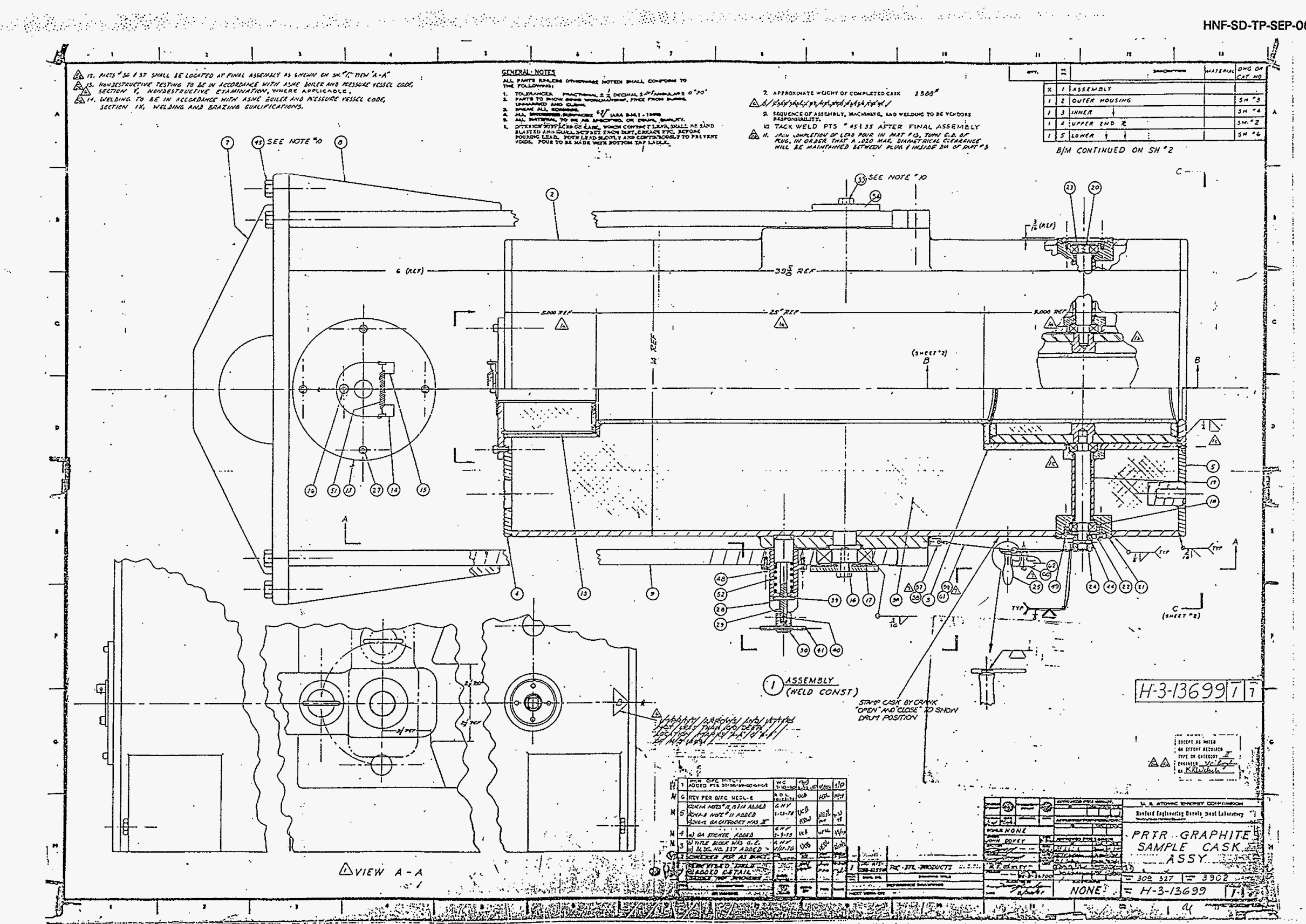




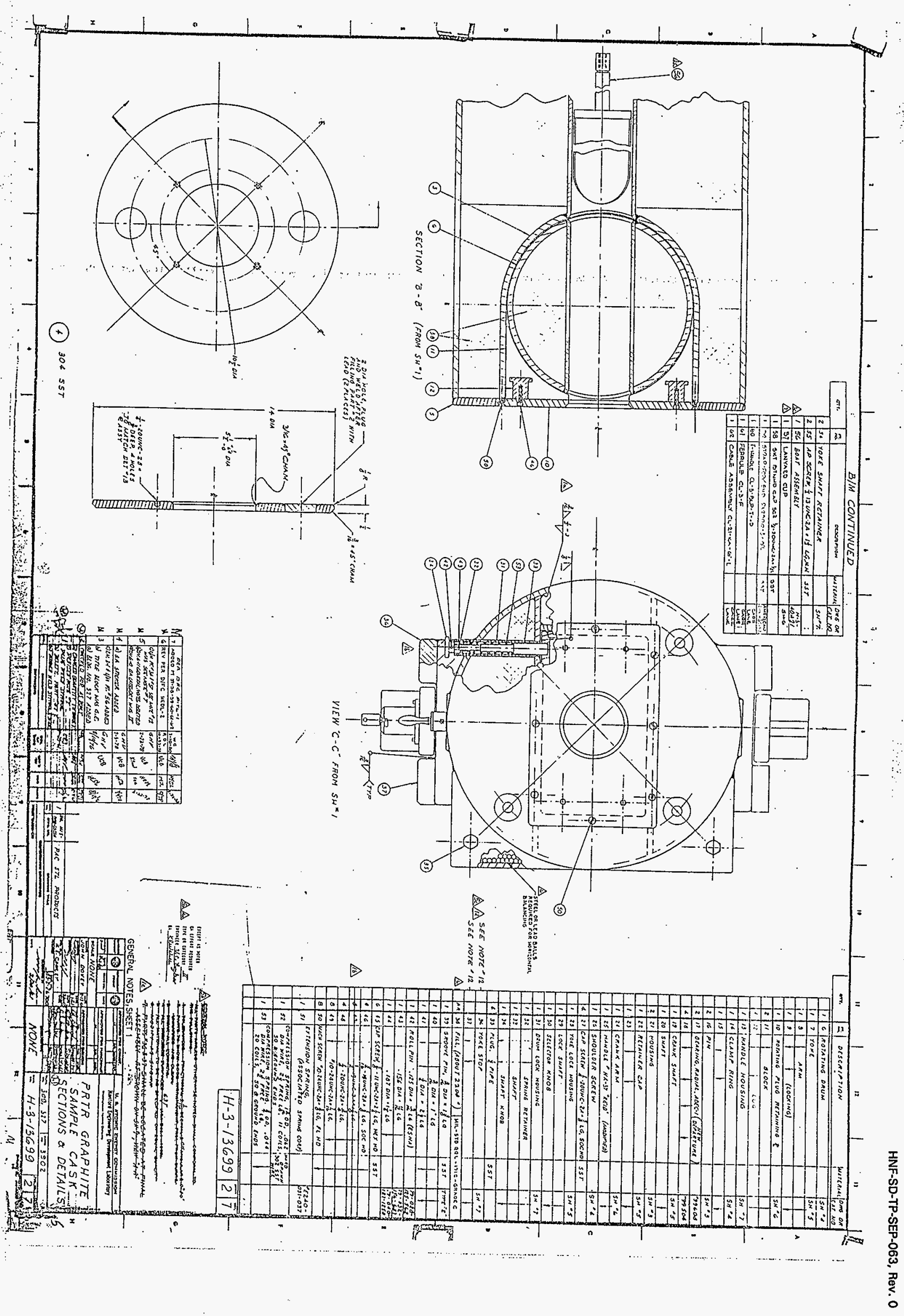




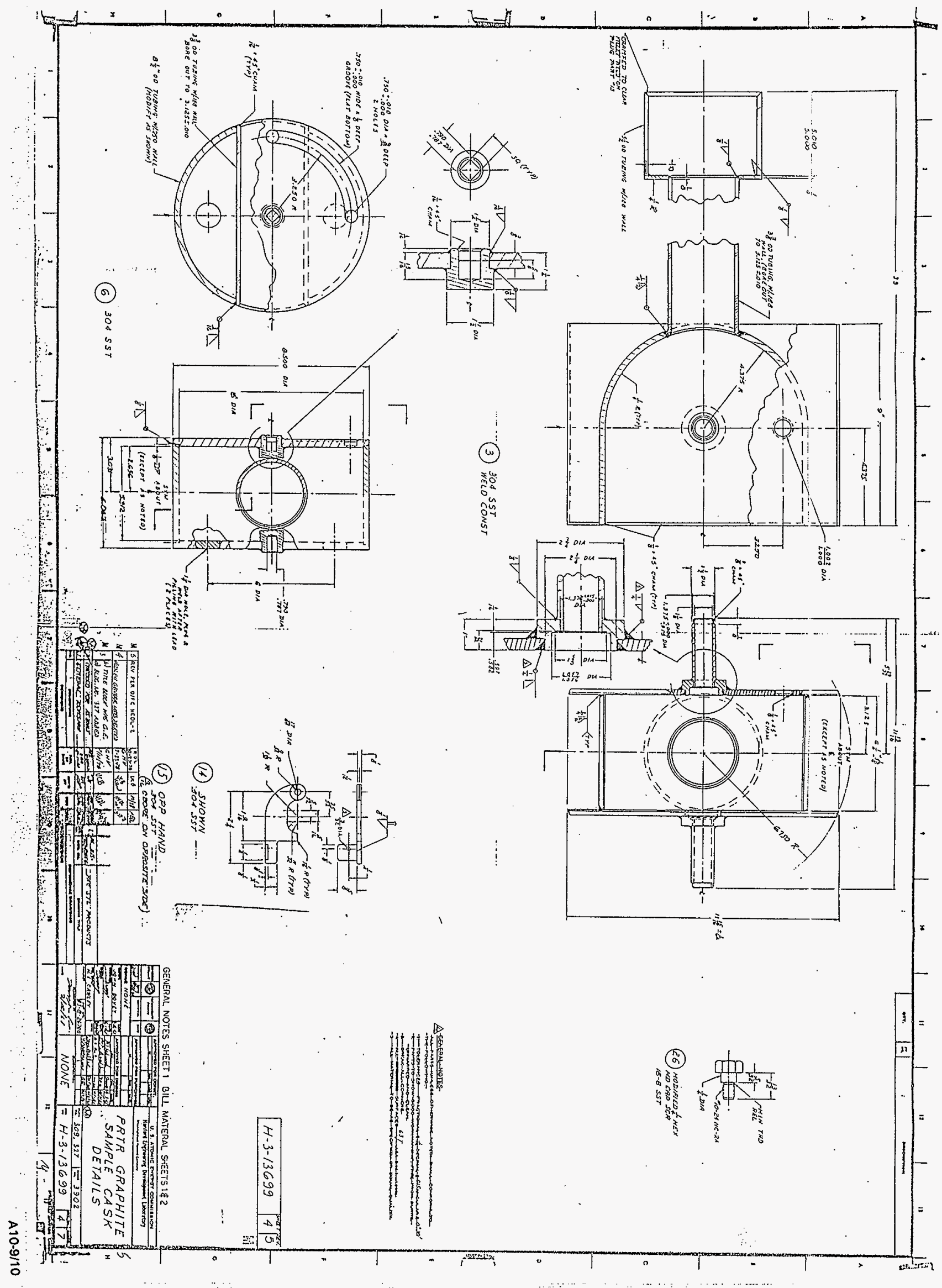




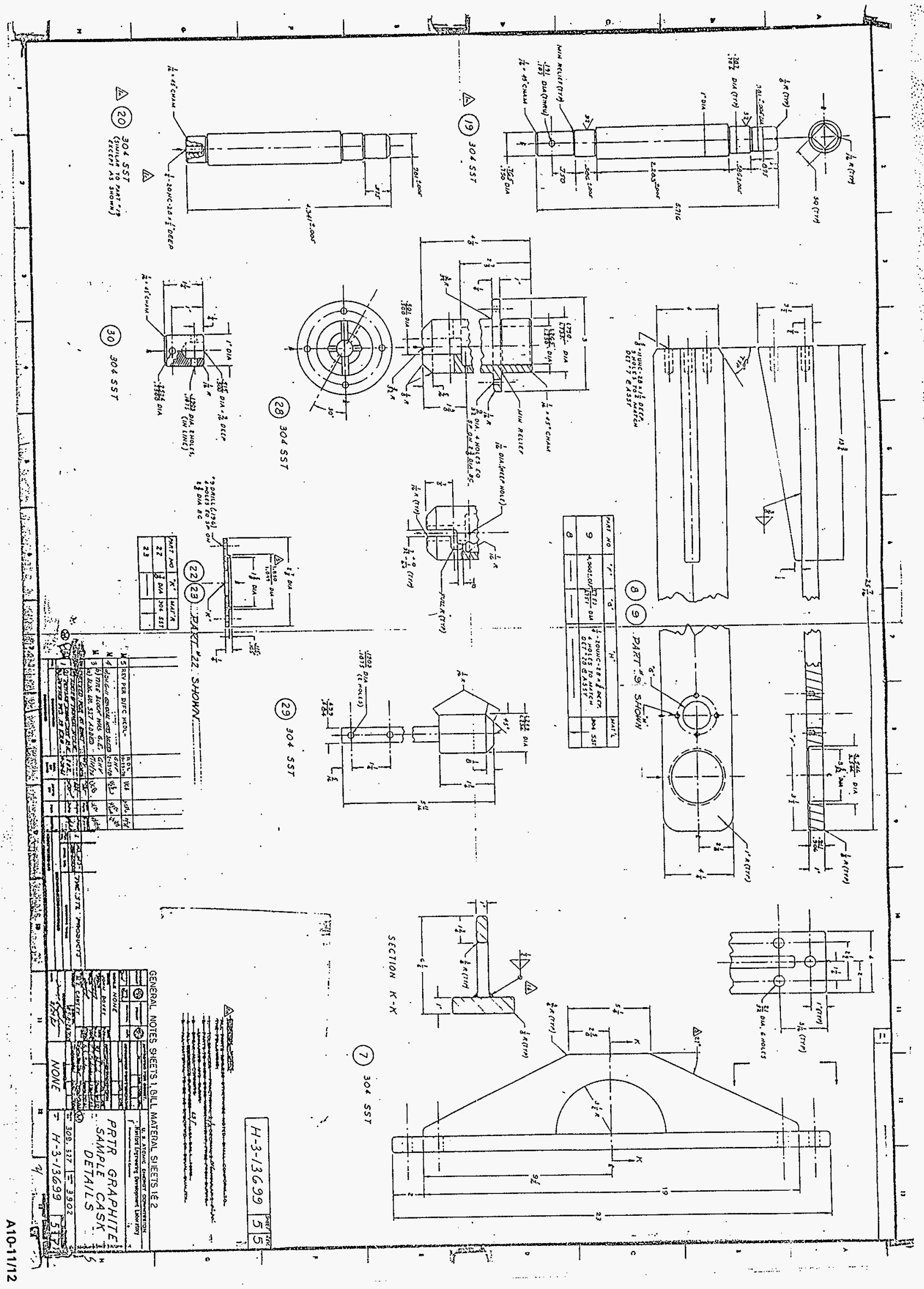




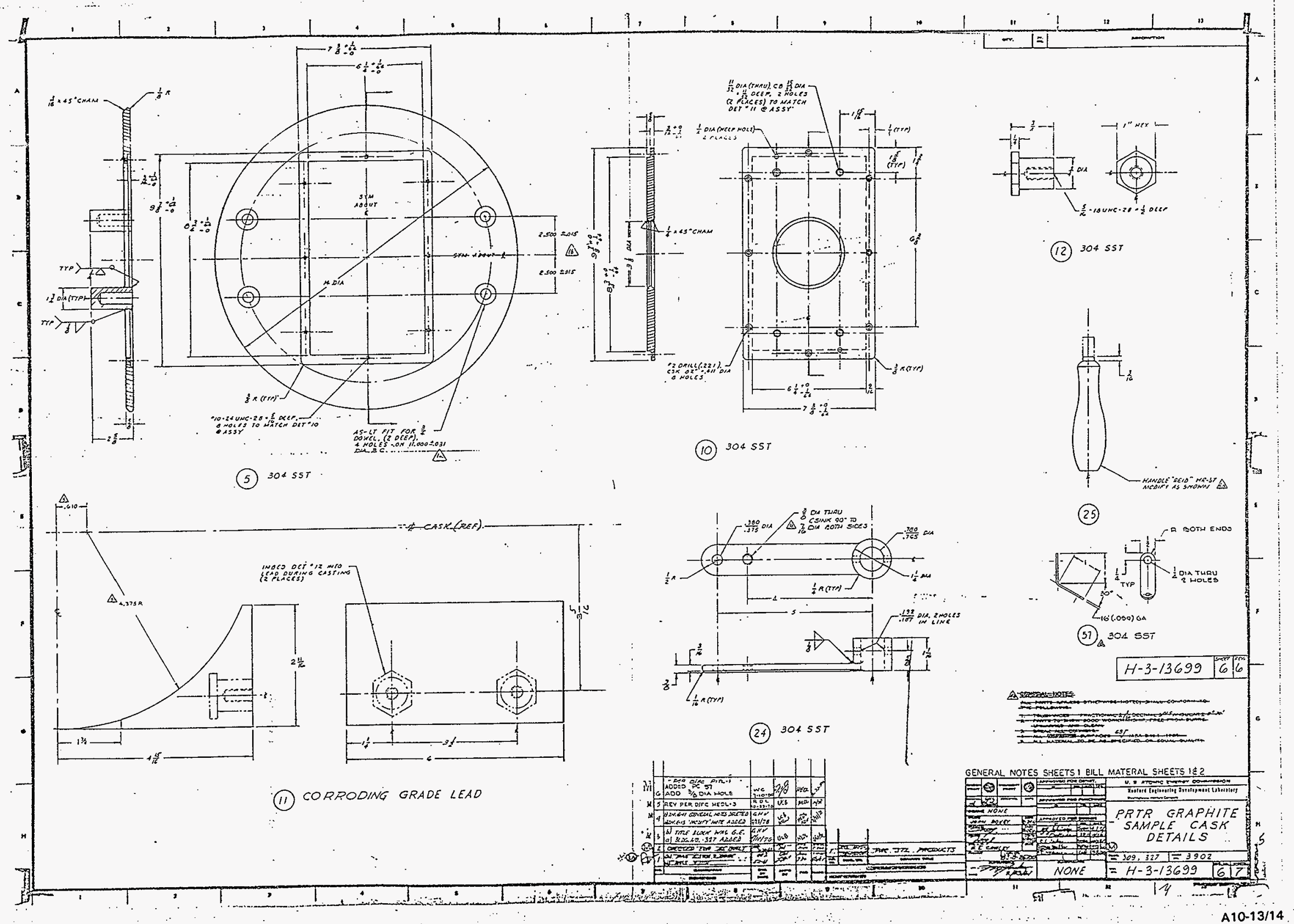




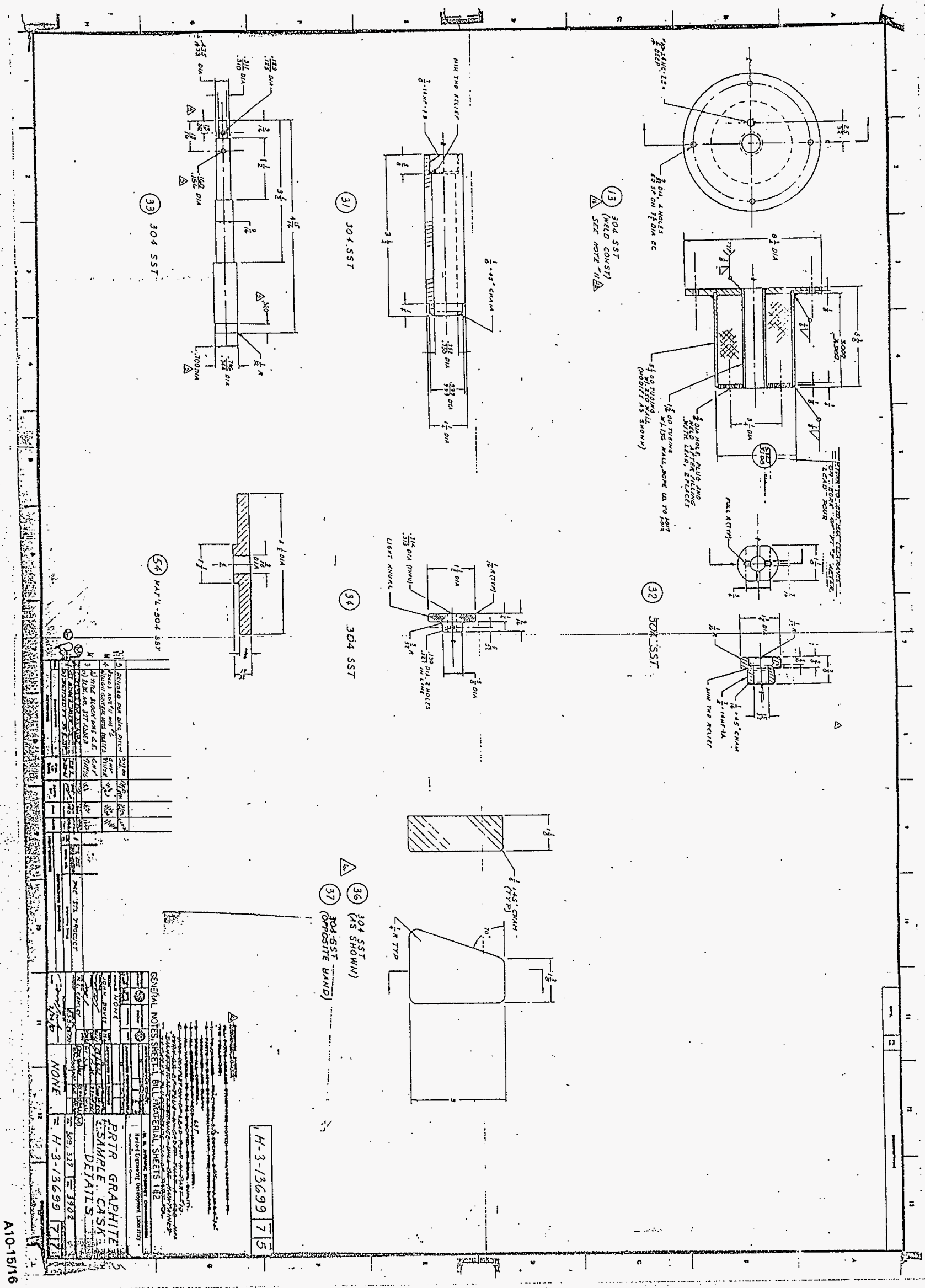


HNF-SD-TP-SEP-063, Rev. 0

\subsection{USER BIENNIAL INSPECTION CHECKLIST AND NONDESTRUCTIVE TESTING OF LIFTING APPARATUS}

BATTELLE

Pacific Northwest Laboratories Rernote Systems Technology Department

RADIOACTIVE MATERIAL SHIPPING CONIAINER BIENNTAL USER INSPECTION CHECKLIST

\begin{tabular}{|c|c|c|c|c|}
\hline \multicolumn{2}{|c|}{ Container No: 2701 } & \multirow[t]{2}{*}{ Inspection Date: } & \multicolumn{2}{|l|}{ Inspection Due: } \\
\hline $\begin{array}{l}\text { Item } \\
\text { No. }\end{array}$ & $\begin{array}{l}\text { Spex: Section } \\
\text { or Ding: View }\end{array}$ & & $\begin{array}{l}\text { Reference or } \\
\text { Test Method }\end{array}$ & $\begin{array}{l}\text { Inspected } \\
\text { By (Init.) }\end{array}$ \\
\hline 1. & $\begin{array}{l}1+3-13699 \\
\text { Sheet } \$ 11\end{array}$ & $\begin{array}{l}\text { Closure "drun" position marked } \\
\text { "OPEN" and "CLOSED" on cask. }\end{array}$ & $\begin{array}{l}\text { Visua1 } \\
\text { Inspection }\end{array}$ & \\
\hline 2. & $\begin{array}{l}\text { H-3-13699 } \\
\text { Sheet } \# 1\end{array}$ & $\begin{array}{l}\text { Closure "drum" handle position } \\
\text { is correct in reference to the } \\
\text { "OPEN" and "ClosED" markings. }\end{array}$ & $\begin{array}{l}\text { Functiona } 1 \\
\text { Test: }\end{array}$ & \\
\hline 3. & $\begin{array}{l}\text { H-3-13699 } \\
\text { Sheet } \$ 2\end{array}$ & $\begin{array}{l}\text { Closure "drum" locking } \\
\text { device functions property. }\end{array}$ & $\begin{array}{l}\text { Functional } \\
\text { Test }\end{array}$ & \\
\hline 4. & $\begin{array}{l}\text { H- } 3-13699 \\
\text { Sheet } \# 2\end{array}$ & $\begin{array}{l}\text { Closure "drum" will close } \\
\text { proper1y with transfer "boat" } \\
\text { positioned to rear of cask. }\end{array}$ & $\begin{array}{l}\text { Functional } \\
\text { Test }\end{array}$ & \\
\hline 5. & $\begin{array}{l}11-3-13699 \\
\text { Sheet } 41\end{array}$ & $\begin{array}{l}\text { Rear locking device holds the } \\
\text { transfer "boat" in position. }\end{array}$ & $\begin{array}{l}\text { Functiona i } \\
\text { Test }\end{array}$ & \\
\hline 6. & $\begin{array}{l}y-3-1.3699 \\
\text { Sheet } ¥ 2\end{array}$ & $\begin{array}{l}\text { Verify that closure "drim" } \\
\text { rotates freely. }\end{array}$ & $\begin{array}{l}\text { Functional } \\
\text { Test }\end{array}$ & \\
\hline 7. & $\begin{array}{l}11-3-13699 \\
\text { Sheet in }\end{array}$ & $\begin{array}{l}\text { Verify that locking pin will } \\
\text { lock fifting "bail" in the } \\
\text { horizontal/vertical position. }\end{array}$ & $\begin{array}{l}\text { Functional } \\
\text { lest: }\end{array}$ & \\
\hline 8 & $3413 \quad 327-5$ & $\begin{array}{l}\text { Verify surface is free of } \\
\text { danage and rust. }\end{array}$ & $\begin{array}{l}\text { Visual } \\
\text { Inspection }\end{array}$ & \\
\hline 9. & JHB $327-5$ & $\begin{array}{l}\text { Verify that no weld cracking } \\
\text { is evident. }\end{array}$ & $\begin{array}{l}\text { Visual } \\
\text { Inspection }\end{array}$ & \\
\hline 10. & JHB $327-5$ & $\begin{array}{l}\text { Check for loose bolts and/or } \\
\text { broken parts. }\end{array}$ & $\begin{array}{l}\text { Visuil } \\
\text { Inspection }\end{array}$ & \\
\hline
\end{tabular}


HNF-SD-TP-SEP-063, Rev. 0

BATTELLE

Pacific Northwest Laboratories

Remote Systems Technology Department

RADIOACTIVE MATERIAL SHIPPING CONTAINER

NDT OF LIFTING APPARATUS ( 5 YEAR)

\begin{tabular}{|c|c|c|c|c|}
\hline \multicolumn{2}{|c|}{ Container No: 2701} & Inspection Date: & \multicolumn{2}{|c|}{ Next Inspection Due: } \\
\hline $\begin{array}{l}\text { Item } \\
\text { No. }\end{array}$ & $\begin{array}{l}\text { Spec: Section } \\
\text { or Dwg: View }\end{array}$ & Characteristic/Requirement & Test Method & $\begin{array}{l}\text { Inspected } \\
\text { By (Init.) }\end{array}$ \\
\hline 1. & $\begin{array}{l}\text { H-3-13699 } \\
\text { Sheet \#1 }\end{array}$ & $\begin{array}{l}\text { WeIds attaching Part \#7 to } 1 " \\
\text { thick Cross Bar. }\end{array}$ & $\begin{array}{l}\text { Dye } \\
\text { penetrant }\end{array}$ & \\
\hline 2. & $\begin{array}{l}H-3-13699 \\
\text { Sheet. 壮 }\end{array}$ & $\begin{array}{l}\text { Welds attaching Part } \# 8 \text { to } \\
\text { Part } \# 9 \text {. }\end{array}$ & $\begin{array}{l}\text { Dye } \\
\text { penetrant }\end{array}$ & \\
\hline
\end{tabular}

EQUIPMENT TEST INFORMATION

1. Requester verifies that the equipment to be examined is:

Safe.

- Possible urisafe conditions.

- Radiation - Dose Rate.

2. Anticipated part temperature: Ambient _other

3. Material type to be examined:

4. Area to be inspected: Spot Inspection - Fu11 Inspection (100\% of area requested).

5. QA Plan: Impact Level: Test Procedure:

6. Acceptance Standard:

7. Comments:

8. QA Rep. contacted: Test Date: Time: Custodian Signature: 
HNF-SD-TP-SEP-063, Rev. 0

PART B: PACKAGE EVALUATION

\subsection{INTRODUCTION}

\subsection{SAFETY EVALUATION METHODOLOGY}

The Plutonium Recycle Test Reactor (PRTR) Graphite Cask was evaluated against the requirements of WHC-CM-2-14, Hazardous Material Packaging and Shipping, for onsite transportation of solid, Type B, fissile, non-highway route controlled quantities (non-HRCO) of radioactive materials. The analyses presented in this safety evaluation for packaging verify the PRTR Graphite Cask meets the onsite transportation safety requirements based on a risk evaluation.

\subsection{EVALUATION SUMMARY AND CONCLUSIONS}

As shown by the following evaluations, the PRTR Graphite Cask is safe for the onsite transportation of solid, Type B, fissile radioactive materials. The cask will prevent loss of contents for normal transport conditions (NTC). A risk evaluation demonstrates that the frequency of an accident resulting in loss of contents is less than the required criteria of $10^{\circ}$.

\subsubsection{Contents}

The typical contents of the PRTR Graphite Cask are evaluated in Part B, Section 2.0.

\subsubsection{Radiological Risk}

The risk evaluation for the PRTR Graphite Cask demonstrates that the PRTR Graphite Cask meets the onsite transportation safety criteria. In order to satisfy that criteria, the 327 Building casks, which include the One-Ton Lab Cask, the Long Bore Cask, the Large Bore Cask, the Radioactive Waste Disposal Cask, the Special Environmental Radiometallurgy Facility (SERF) Cask, and the PRTR Graphite Cask, cannot be transported more than a total of $16.0 \mathrm{~km}(10.0 \mathrm{mi})$ in any calendar year.

\subsubsection{Containment}

The containment system consists of the PRTR Graphite Cask and the inner container. The radioactive contents are contained inside the inner container, which is either a glass or plastic vial. The vials are placed in a slip lid container, which, in turn, is placed in two 10-mil plastic bags that are sealed with duct tape. The plastic vials can also be placed in two 10-mil plastic bags that are sealed with duct tape. Both types of vials are closed with screw caps. The containment evaluation is presented in Part B, Section 4.0.

\subsubsection{Shielding}

The shielding analysis for the source term is presented in Part B, Section 5.0. The cask provides the shielding required to meet the established radiological dose rate criteria. 


\subsubsection{Criticality}

The criticality analysis for the PRTR Graphite Cask is contained in Limits for Fissionable Material in Small Bore Transfer Casks and Lead Pigs (Larson 1996). The limit for ${ }^{235} \mathrm{U}$ only is $275 \mathrm{~g}$, while the limit for other fissionable materials is $175 \mathrm{~g}$.

\subsubsection{Structural}

The structural analysis for the PRTR Graphite Cask is contained in Part B, Section 7.0. This analysis shows the PRTR Graphite Cask and the inner containers contain the contents and maintain shielding during all NTC. Accident conditions are addressed in the risk evaluation.

\subsubsection{Thermal}

The thermal analysis for the PRTR Graphite Cask is contained in Part B, Section 8.0. This analysis demonstrates that the PRTR Graphite Cask performs acceptably during extreme weather conditions on the Hanford Site.

\subsubsection{Gas Generation}

The contents of the PRTR Graphite Cask will be dry to prevent gas generation from radiolysis.

\subsubsection{Tiedown System}

The package tiedown evaluation in Part B, Section 10.0, ensures that the PRTR Graphite Cask will remain on the trailer under NTC.

\subsection{REFERENCES}

Larson, S. L., 1996, Limits for Fissionable Material in Small Bore Transfer Casks and Lead Pigs (NCS Basis Memo 96-2 to M. Dec, December 30), Battelle Pacific Northwest Laboratories, Richland, Washington.

WHC-CM-2-14, Hazardous Material Packaging and Shipping, Westinghouse Hanford Company, Richland, Washington. 


\subsection{CONTENTS EVALUATION}

\subsection{CHARACTERIZATION}

Contents to be transported in the PRTR Graphite Cask shall consist of irradiated fuel assemblies, fuel pieces, and various activated materials. The contents shall be limited to the maximum allowable source term shown in Table B2-1.

Table B2-1. Maximum Allowable Source Term.

\begin{tabular}{|l|c|c|}
\hline \multirow{2}{*}{\multicolumn{1}{|c|}{ Material }} & \multicolumn{2}{c|}{ Activity limit } \\
\cline { 2 - 3 } & TBq & $\mathrm{Ci}$ \\
\hline Fissile materials and $\alpha$ emitters & \\
\hline Mixed fission products & 0.401 & 10.9 \\
\hline Mixed activation products & 13.9 & 375 \\
\hline
\end{tabular}

*Fissile/fissionable materials limited by criticality safety as shown in Part B, Section 2.1.1.

The maximum number of $A_{2} s$ and thermal characteristics of the contents are determined as shown Table B2-2. Note that the isotopes assumed for $A_{2}$ calculations are for the worst-case inventory.

Table B2-2. Decay Heat and $A_{2}$ Calculation for the Plutonium Recycle Test Reactor Graphite Cask.

\begin{tabular}{|c|c|c|c|c|c|c|}
\hline \multirow{2}{*}{ Nuclide } & \multicolumn{2}{|c|}{ Activity } & \multirow{2}{*}{$\begin{array}{l}\text { Heat production } \\
\text { factor }(W / C i)\end{array}$} & \multirow{2}{*}{$\begin{array}{c}\text { Heat generation } \\
\text { rate }(W)\end{array}$} & \multirow{2}{*}{. $A_{2}\langle C i\rangle$} & \multirow[b]{2}{*}{$\mathrm{A}_{2} \mathrm{~s}$} \\
\hline & $\mathrm{Bq}$ & $\mathrm{Ci}$ & & & & \\
\hline${ }^{90} \mathrm{Sr}$ & $1.39 E+13$ & $3.75 E+02$ & $1.16 \mathrm{E}-03$ & 0.44 & $2.70 E+O O$ & $1.39 \mathrm{E}+02$ \\
\hline${ }^{90} Y$ & $1.39 E+13$ & $3.75 \mathrm{E}+\mathrm{O} 2$ & $5.54 \mathrm{E}-03$ & 2.08 & $0.00 E+00$ & $0.00 \mathrm{E}+00$ \\
\hline${ }^{60} \mathrm{Co}$ & 1.85E+11 & $5.00 E+00$ & $1.54 \mathrm{E}-02$ & 0.08 & $1.08 E+01$ & 4.63 E-O1 \\
\hline${ }^{239} \mathrm{Pu}$ & $4.01 E+11$ & $1.09 \mathrm{E}+01$ & $3.06 \mathrm{E}-02$ & 0.33 & $5.41 \mathrm{E}-03$ & $2.01 E+03$ \\
\hline Total & $2.83 E+13$ & $7.66 \mathrm{E}+02$ & & 2.92 & . & $2.14 E+03$ \\
\hline
\end{tabular}

As. shown in Table B2-2, the number of $A_{2} s$ is less than 3,000; therefore, the maximum radioactive material inventory is a fissile. Type- $B$, non-HRCQ (49 CFR 173). 


\subsubsection{Fissile Material Content}

The fissile/fissionable material limits for the PRTR Graphite Cask are shown in Table B2-3. These limits are $275 \mathrm{~g}$ of ${ }^{235} \mathrm{U}$ or an aggregate total of $175 \mathrm{~g}$ of ${ }^{239} \mathrm{Pu},{ }^{233} \mathrm{U},{ }^{237} \mathrm{~Np},{ }^{241} \mathrm{Am},{ }^{243} \mathrm{Am},{ }^{244} \mathrm{Cm}$, and ${ }^{247} \mathrm{Cm}$. Note that mixtures of fissionable material are possible provided that the sum-of-fractions method shown in Criticality Safety (PNL 1994) is followed.

Table B2-3. Fissile/Fissionable Material Limits in the Plutonium Recycle Test Reactor Graphite Cask.

\begin{tabular}{|c|c|}
\hline Material & Limit \\
\hline${ }^{235} \mathrm{U}$ & $275 \mathrm{~g}^{*}$ or \\
\hline $\begin{array}{l}{ }^{239} \mathrm{Pu},{ }^{233} \mathrm{U},{ }^{237} \mathrm{~Np},{ }^{241} \mathrm{Am}, \\
{ }^{243} \mathrm{Am},{ }^{244} \mathrm{Cm} \text {, and }{ }^{247} \mathrm{Cm}\end{array}$ & $175 \mathrm{~g}$ aggregate total ${ }^{*}$ \\
\hline $\begin{array}{l}{ }_{\text {or }}^{242 m}{ }^{251} \mathrm{Cf}, \\
{ }^{243} \mathrm{Cm},{ }^{245} \mathrm{Cm},{ }^{249} \mathrm{Cf} \text {, }\end{array}$ & $\begin{array}{l}\text { Not analyzed and cannot be shipped in excess } \\
\text { of safeguards accountability limits* }\end{array}$ \\
\hline
\end{tabular}

Source: Larson, S. L., 1996, Limits for Fissionable Material in Small Bore Transfer Casks and Lead Pigs (NCS Basis Memo 96-2 to M. Dec, December 30), Battelle Pacific Northwest Laboratories, Richland, Washington.

* Mixtures of fissionable material are possible provided that the sum-offractions method shown in PNL (1994) and referenced in Larson (1996), attached in Part B, Section 6.0, is followed.

PNL, 1994, Criticality Safety, PNL-MA-25, Battelle Pacific Northwest Laboratories, Richland, Washington.

\subsection{RESTRICTIONS}

Contents as shown in Part B, Tables B2-1 and B2-3, including daughter isotopes, are the only contents authorized for the PRTR Graphite Cask. All contents shall be in inner containers as described in Table B2-4.

\subsection{SIZE AND WEIGHT}

Only contents smaller than the internal cavity can be shipped in the PRTR Graphite Cask. The empty weight of the cask is $1,089 \mathrm{~kg}(2,400 \mathrm{lb})$. The total gross weight of the PRTR Graphite Cask and its contents shall not exceed $1,202 \mathrm{~kg}(2,650 \mathrm{lb})$.

\subsection{CONCLUSIONS}

The fissionable material limits described in Limits for Fissionable Material in Small Bore Transfer Casks and Lead Pigs (Larson 1996) and discussed in Part B, Section 6.0, and the shielding analyses, shown in Part B, Section 5.0, demonstrate that the PRTR Graphite Cask can ship the contents shown in Tables B2-1 and B2-3 safely. The established limits will preclude the possibility of a criticality and minimize radiological exposure to personnel during transport.

As shown in Table B2-2, the maximum quantity of material to be shipped is a fissile. Type B non-HRCQ (49 CFR 173). 
Table B2-4. Inner Container Description.

\begin{tabular}{|c|c|c|}
\hline Inner container & Contents & Examples of contents \\
\hline $\begin{array}{l}\text { Pin tubes-tubes and fittings must have } \\
\text { a working rating of } 20.68 \mathrm{MPa} \\
\text { ( } 3000 \text { psi), with an outer diameter of } \\
1.3 \mathrm{~cm}(0.50 \mathrm{in.} \text { ) or } 1.9 \mathrm{~cm}(0.75 \mathrm{in} .) \text {. } \\
\text { The tubes are welded on one end. A } \\
\text { Swagelok* fitting is used as closure. }\end{array}$ & Dispersible solid materials & $\begin{array}{l}\text { Irradiated structural materials; solid } \\
\text { pieces of irradiated FFTF, PNC, and } \\
\text { N Reactor fuel pins; and small pieces } \\
\text { or test samples of irradiated fuel and } \\
\text { structural materials }\end{array}$ \\
\hline $\begin{array}{l}\text { DOT Specification } 2 \mathrm{R} \text { per } 49 \mathrm{CFR} \\
178.360\end{array}$ & Dispersible'solid materials & $\begin{array}{l}\text { Irradiated structural materials; solid } \\
\text { pieces of irradiated FFTF, PNC, and } \\
N \text { Reactor fuel pins; and small pieces } \\
\text { or test samples of irradiated fuel and } \\
\text { structural materials in glass or plastic } \\
\text { vials with screw cap }\end{array}$ \\
\hline $\begin{array}{l}\text { Large solid item put directly into the. } \\
\text { cask }\end{array}$ & $\begin{array}{l}\text { Nondispersible solid } \\
\text { structural material and } \\
\text { activated metals put } \\
\text { directly into the cask ** }\end{array}$ & $\begin{array}{l}\text { Large solid items with fixed surface } \\
\text { contamination }\end{array}$ \\
\hline
\end{tabular}

DOT $=$ U.S. Department of Transportation.

FFTF = Fast Flux Test Facility.

PNC = Power Reactor and Nuclear Fuel Development Corporation.

* Swagelok is a trademark of the Crawford Fitting Company.

- * Surface contamination limits not to exceed 100 times the Table A4-1 limits. Verification by survey or the use of a fixative, such as paint, is required.

49 CFR 178, 1997, "Specifications for Packagings," Code of Federal Regulations, as amended.

\subsection{REFERENCES}

49 CFR 173, 1997, "Shippers--General Requirements for Shipments and Packagings," Code of Federal Regulations, as amended.

49 CFR 178, 1997, "Specifications for Packagings," Code of Federal Regulations, as amended.

Larson, S. L., 1996, Limits for Fissionable Material in Small Bore Transfer Casks and Lead Pigs (NCS Basis Memo 96-2 to M. Dec, December 30), Battelle Pacific Northwest Laboratories, Richland, Washington.

PNL, 1994, Criticality Safety, PNL-MA-25, Battelle Pacific Northwest Laboratories, Richland, Washington. 
HNF-SD-TP-SEP-063, ReV. 0

This page left intentionally blank.

B2-4 
HNF-SD-TP-SEP-063, Rev. 0

\subsection{RADIOLOGICAL RISK EVALUATION}

\subsection{INTRODUCTION}

The 327 Building casks, which include the One-Ton Lab Cask, the Long Bore Cask, the Large Bore Cask, the Radioactive Waste Disposal Cask, the SERF Cask, and the PRTR Graphite Cask, are used to transport Type B non-HRCQs of solid activated metals, irradiated fuel, and other solid radioactive materials among the 300 Area laboratories. Because none of the 327 Building casks are certified Type B containers, radiological risks are evaluated to determine compliance with onsite transportation safety requirements per WHC-CM-2-14. Although separate safety documentation has been issued for each cask, the radiological risk evaluation is prepared for the 327 Building casks as a composite analysis. The composite analysis was prepared due to the similarity in payload, cask type, and transport environment.

The 327 Building casks are used routinely over short distances (less than $0.40 \mathrm{~km}[0.25 \mathrm{mi}]$ ) within the 300 Area. The casks are transported by truck.

The assumptions for the radiological risk evaluation are summed as follows:

- Highway mode

- Approximately $0.40 \mathrm{~km}(0.25 \mathrm{mi})$ per trip

- A maximum of 24 trips per year

- One cask per shipment.

For accident environments, the 327 Building casks must meet onsite transportation safety requirements as outlined in WHC-CM-2-14 and Mercado (1994). The required safety is determined by a radiological risk evaluation that uses dose consequences, risk acceptance criteria, cask failure threshold values, and Hanford Site accident frequencies. For the evaluation, accidents are categorized as resulting in impact, crush, puncture, and fire forces. Risk acceptance criteria are outlined in Part B, Section 3.2, and the dose consequence analyses results are provided in Part B, Section 3.3. Cask failure thresholds are given in Part B, Section 3.4. The analysis of accident release frequencies for associated failure thresholds is documented in Part B, Section 3.5. The accident release frequencies are compared to the risk acceptance criteria determined from the dose consequence analysis to evaluate the acceptability of the risks related to the 327 Building cask shipments.

\subsubsection{Summary of Results}

Based on the transport of one 327 Building cask per shipment, the dose consequence analysis resulted in a risk acceptance criterion of an annual accident release frequency of less than $10^{-7}$. The release frequency and conditional probability analysis showed that the criterion is met for shipments totaling over $16.0 \mathrm{~km}$ (10.0 mi) per year. Therefore, 24 shipments per year of $0.40 \mathrm{~km}(0.25 \mathrm{mi}$ ) each easily falls within the range of the acceptable risks as required to meet onsite transportation safety per WHC-CM-2-14. The risk evaluation shows that up to 40 transfers of $0.40 \mathrm{~km}(0.25 \mathrm{mi})$ may be made per year.

\subsection{RISK ACCEPTANCE CRITERIA}

Graded dose limitations for probable, credible, and incredible accident frequencies ensure safety in radioactive material packaging and transportation (Mercado 1994). The dose limitations to the offsite and onsite individual for probable, credible, and incredible accident frequencies are shown in Table B3-1. 
HNF-SD-TP-SEP-063, Rev. 0

Table B3-1. Risk Acceptance Criteria Limits.

\begin{tabular}{|l|c|c|c|}
\hline Description & Annual frequency & $\begin{array}{c}\text { Offsite dose limit* } \\
\text { (rem) }\end{array}$ & $\begin{array}{c}\text { Onsite dose limit* } \\
\text { (rem) }\end{array}$ \\
\hline Incredible & $<10^{-7}$ & None & None \\
\hline Incredible & $10^{-7}$ to $<10^{-6}$ & 25 & None \\
\hline Credible & $10^{-6}$ to $10^{-3}$ & 0.5 & 5 \\
\hline Probable & $10^{-3}$ to 1 & 0.01 & 0.2 \\
\hline
\end{tabular}

*Total effective dose equivalent.

\subsection{DOSE CONSEQUENCE ANALYSIS RESULTS}

The dose consequence study for the 327 Building casks is presented in Part B, Section 4.0, of this safety evaluation for packaging. The analysis does not take credit for the package, rather it follows International Atomic Energy Agency (IAEA) guidelines and evaluates doses for a release of $100 \%$ of the material at risk. The accident results are shown in Table B3-2 for a ground-level release at the worst location with worst-case $(0.5 \%)$ meteorology. The doses shown in Table B3-2 are the total committed effective dose equivalents (EDE), which are integrated over 50 years.

Table B3-2. Summary of Doses.

\begin{tabular}{|c|c|c|}
\hline Exposure pathway & Offsite receptor (rem) & Onsite worker (rem) \\
\hline Total effective dose equivalent & 68 & 2000 \\
\hline
\end{tabular}

When compared to the risk criteria given in Tabie B3-1, the potential dose to the offsite receptor requires that the 327 Building casks maintain annual accident release frequencies of less than $10^{-7}$ probability of occurrence per year. Therefore, the annual accident release frequency is limited to less than $10^{-7}$ per year.

\subsection{PACKAGE FAILURE THRESHOLD ANALYSIS}

Accident performance of a package is determined by the probability, given an accident, that a package is subjected to a force more severe than the package failure threshold level for that accident scenario. For the 327 Building casks, the failure thresholds are assumed to be minimal, and the package is assumed to fail if an accident occurs. The failure threshold of the 327 Building casks has been determined for puncture.

- Impact: No impact analysis was performed; the 327 Building casks are assumed to fail in the event of an impact.

- Puncture: The puncture failure threshold is based on the equivalent steel thickness of the package. The equivalent steel thickness for each of the six casks is at least $6.4 \mathrm{~cm}$ (2.5 in.). This evaluation is documented in Part B, Section 7.0, page B7-15. 
- Crush: No crush analysis was performed; the 327 Building casks are assumed to fail in any accident involving crush.

- Fire: No fire failure analysis was performed, therefore the 327 Building casks are assumed to fail any accident involving a fire.

\subsection{ACCIDENT RELEASE FREQUENCY ASSESSMENT}

\subsubsection{Approach}

The accident release frequency assessment is based on the assumption that all failure modes from the different forces described as impact, puncture, crush, and fire result in the same level of consequence. The union of the package conditional release probabilities from different scenarios with similar consequences is multiplied by the frequency of truck accidents to arrive at a total annual accident release frequency.

The frequency (F) of a truck accident is the product of the annual number of trips, the number of miles per trip, and the accident rate per mile.

$$
F=\frac{\text { number of trips }}{\text { year }} \times \frac{\text { miles }}{\text { trip }} \times \frac{\text { accidents }}{\text { mile }}
$$

Hanford Site truck accidents have been compiled in a report using Site-specific data (Green et al. 1996), which gives the accident rate for trucks as $2.0 \times 10^{-7}$ accidents per mile. For a shipment of radioactive materials that is carried out by trained truck drivers during daylight hours in good road conditions, a reduction factor of 20 can be applied to lower the rate to $1 \times 10^{-8}$ (H\&R 1995) accidents per mile. Appendix B of Recommended Onsite Transportation Risk Management Methodology (H\&R 1995) summarizes statistics from the U.S. Department of Transportation (DOT) and the studies conducted by Sandia National Laboratory on accident responses of small and large packages. The report recommends reducing truck accident rates by 10 for "safe" truck drivers and another factor of two for shipment of radioactive material. These reduction factors are based on the following logic.

- Safe truck drivers: Hanford Site truck drivers have special training. Drivers must complete several driver's education courses, have a valid commercial driver's license with hazardous endorsement, complete specific training for highway route controlled quantities of radioactive material, and complete radiation worker and hazardous materials training. References show that drivers who participate in special safety programs reduce single-vehicle accident rates by up to a factor of 100 . The $H \& R$ report (H\&R 1995) recommends using an overall accident reduction factor of 10 .

- Radioactive material: Ari additional factor of two is recommended based on the higher level of training required for drivers of vehicles carrying radioactive material and the higher level of caution that would be expected from drivers of cargos consisting of radioactive material.

After the frequency of accidents is calculated, it is then multiplied by the union of the conditional release probabilities determined in Part B, Section 3.5.2, to arrive at an annual accident release frequency. The annual release frequency is compared to the criteria determined from the dose consequence analysis $\left(<10^{-7}\right)$. 
HNF-SD-TP-SEP-063, Rev. 0

\subsubsection{Accident Release Frequency Analysis}

Information for the probability of occurrence and conditional probabilities of failure is taken from Severities of Transportation Accidents Involving Large Packages (Dennis et al. 1978). Severities of Transportation Accidents Volume III - Motor Carriers (Clarke et al. 1976), and H\&R (1995). A simplified generic flow chart, shown in Figure B3-1, has been developed using statistics presented in Clarke et al. (1976) and Dennis et al. (1978). It visually depicts events that may occur as a result of a truck accident on the Hanford Site. Scenarios, such as immersion, that are not pertinent to the shipment of radioactive material on the Hanford Site are not included. Package failure and material release may occur from fire, impact, crush, and puncture, which for purposes of the joint probability calculations are assumed to be independent events.

The probability of an event in the flow chart, given a preceding event, is determined from the studies presented with large and small packages in Clarke et al. (1976) and Dennis et al. (1978). Thus, as can be seen in Figure B3-1, the probability of a fire only given a truck accident is 0.0110 , and the probability of an accident resulting in collission or overturn is 0.8935 (Clarke et al. 1976 Ip.13]). Trivial accidents are defined only in terms of the cargo and refer to those accidents that do not affect the payload (for example accidents with objects of much lesser mass).

The crush force in the flow chart represents static crush. For large packages inertial crush falls under the category of an impact force, and impact failure thresholds are accordingly evaluated for either impact or inertial crush failure, whichever is the limiting value. The conditional probability of static crush given a collision or overturn accident is found in Dennis et al. (1978 [p. II-25]) as 0.05. This means that 1 in 20 collision or overturn accidents results in static crush to the package. Use of the 0.05 value is recommended in Dennis et al. (1978) even though the study states that accident statistics indicate a lower rate would be more representative of accident conditions.

The impact environment may result in puncture or impact failure for large packages.

Dennis et al. (1978) cites a value of 0.8020 for the probability of an impact or inertial crush force given an accident. Accordingly, the probability of an impact force occurring given a collision or overturn is calculated to be $0.8976(0.8020 / 0.8935)$. In a similar manner, the conditional probability of fire given a collision or overturn is calculated from the fire frequency per accident of $1.6 \%$ (Dennis et al. 1978 [p. ||$-15]\}$ and the value for the fire-only scenario of 0.0110 . It is worth noting that the statistics in Dennis et al. (1978) do not discriminate between fires that affect cargo and fires that do not affect cargo. Therefore, some overconservatism may result from the assumption that all fires affect the cargo.

3.5.2.1 Conditional Release Probabilities. Conditional release probabilities for crush are either 1.0 for failure or 0 for no failure. In an accident involving crush, for example, failure occurs if the static crush failure threshold for the package is less than the weight of the truck trailer. No other static crush force will occur on the Hanford Site. For the 327 Building casks, the conditional release probability due to crush-induced failure (PCF) is 1.0 because the casks are assumed to fail in any accident involving crush forces.

The conditional probability of release from failure from fire $\{P F F\}$ is determined from an $H \& R$ report (H\&R 1995), which incorporates Hanford Site information for emergency response time and fire duration. The value represents the probability that the fire duration is greater than the length of time determined to be the failure point for the package. For the 327 Building casks, PFF is equal to 1.0 because the package is assumed to fail any fire.

The conditional probability of release from puncture given an impact event (PPF) represents the probability that an impact event will result in a puncture force large enough to penetrate and fail the equivalent steel thickness of the package. The PPF values are found in Dennis et al. (1978 [p. II-35]). The 327 Building casks have an equivalent steel thickness of $6.6 \mathrm{~cm}(2.6 \mathrm{in})$, which is rounded down to $6.4 \mathrm{~cm}\left(2.5 \mathrm{in}\right.$.) for a PPF value of $4.36 \times 10^{-10}$. 
HNF-SD-TP-SEP-063, Rev. 0

Figure B3-1. Flow Chart for Hanford Site Large Package Truck Accidents.

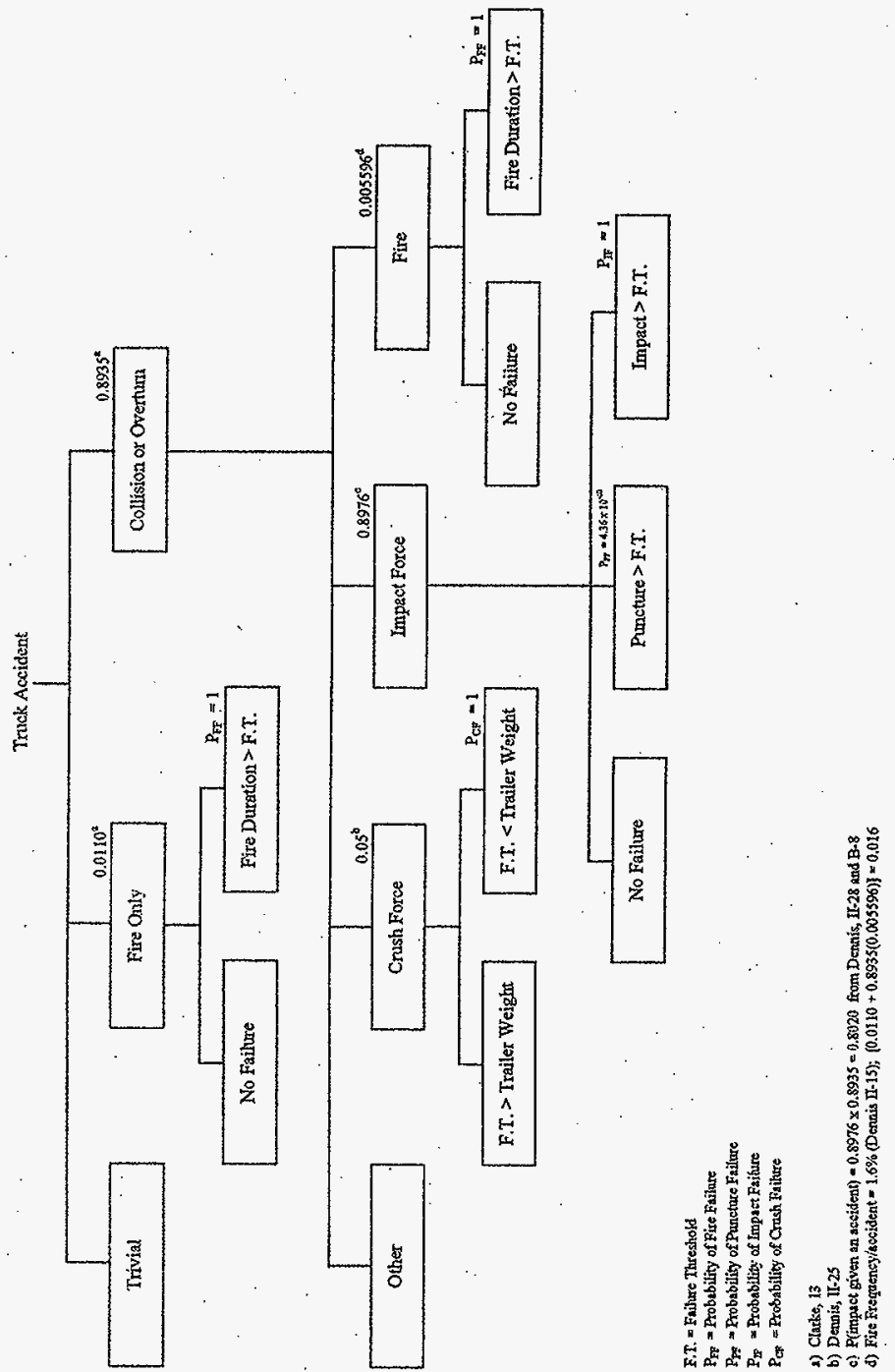


The conditional probability of release from impact forces given an impact event (PIF) represents the probability that the package will be subjected to an impact resulting in a velocity change greater than that which could fail the package. As previously stated, inertial crush is included in this category. The values for the impact conditional release probabilities are found in Dennis et al. (1978 [p. II-23]). For the 327 Building casks, the PIF is conservatively assumed to be 1.0 .

Table B3-3. Failure Thresholds and Conditional Release Probabilities.

\begin{tabular}{|l|c|c|}
\hline \multicolumn{1}{|c|}{ Force type } & Failure threshold & $\begin{array}{c}\text { Conditional release } \\
\text { probability }\end{array}$ \\
\hline Crush & . Fails crush & 1.0 \\
\hline Puncture & $6.4 \mathrm{~cm}(2.5$ in. $)$ & $4.36 \times 10^{-10}$ \\
\hline Fire & Fails any fire & 1.0 \\
\hline Impact & Fails any impact & 1.0 \\
\hline
\end{tabular}

3.5.2.2 Joint Probabilities. Conditional release probabilities and failure thresholds are shown in Table B3-3. The joint probability is calculated by taking the union of events (McCormick 1981). The equation represents the sum of the probabilities of independent events while the subtracted terms eliminate double counting arising from the overlap caused by the intersection of the events. The general equation is given as:

$$
\begin{gathered}
P\left(A_{1}+A_{2}+\ldots+A_{N}\right)=\sum_{n=1}^{N} P\left(A_{n}\right)-\sum_{n=1}^{N-1} \sum_{m=n+1}^{N} P\left(A_{n} A_{m}\right)+\cdots \\
\ldots+(-1)^{N-1} P\left(A_{1} A_{2} \ldots A_{N}\right) .
\end{gathered}
$$

where

$P(f \mid a)=$ the probability of fire given that an accident has occurred

$P(f c \mid a)=$ the probability of fire and crush given that an accident has occurred

and

P(FTE $f \mid f)=$ the probability that the failure threshold is exceeded by fire given that a fire has occurred

then the above equation can be expanded and written as:

$$
\begin{aligned}
P= & P(f \mid a) P(F T E ~ f \mid f)+P(c \mid a) P(F T E ~ c \mid c)+P(1 \mid a) P(F T E ~ \| l)+ \\
& P(p \mid a) P(F T E ~ p \mid p)-P(f c \mid a) P(F T E f \mid f) P(F T E c \mid c)- \\
& P(f i \mid a) P(F T E ~ f \mid f) P(F T E|| l)-\ldots
\end{aligned}
$$

When substituted in the above equation, the values from the flow chart in Figure B3-1 and the conditional probabilities from Table 3-3 yield a total conditional release probability of 0.978 .

\subsection{EVALUATION AND CONCLUSION}

The total conditional release probability of 0.978 is multiplied by the frequency $(F)$ to arrive at an annual accident release frequency. The annual accident release frequency for 24 shipments of 
327 Building casks is $5.9 \times 10^{-8}$. This value is less than the $1 \times 10^{-7}$ required. In fact, the 327 Building casks can be shipped for up to $16.0 \mathrm{~km}(10.0 \mathrm{mi})$ per year, and the release frequency is less than the criterion.

\subsection{REFERENCES}

Clarke, R. K., J. T. Foley, W. F. Hartman, and D. W. Larson, 1976, Severities of Transportation Accidents, Volume III - Motor Carriers, SLA-74-0001, Sandia National Laboratories, Albuquerque, New Mexico.

Dennis, A. W., J. T. Foley, W. F. Hartman, and D. W. Larson, 1978, Severities of Transportation Accidents Invo/ving Large Packages, SAND77-0001, Sandia National Laboratories, Albuquerque, New Mexico.

DOE, 1994, Airborne Release Fractions/Rates and Respirable Fractions for Nonreactor Nuclear Facilities, DOE-HDBK-3010-94, U.S. Department of Energy, Washington, D.C.

Green, J. R., B. D. Flanagan, and H. W. Harris, 1996, Hanford Site Truck Accident Rate, 1990-1995, WHC-SD-TP-RPT-021, Rev. 0, Westinghouse Hanford Company, Richland, Washington.

H\&R, 1995, Recommended Onsite Transportation Risk Management Methodology, H\&R522-1, H\&R Technical Associates, Inc., Oak Ridge, Tennessee.

McCormick, N. J., 1981, Reliability and Risk Analysis: Methods and Nuclear Power Applications, Academic Press, San Diego, California.

Mercado, J. E., 1994, Report on Equivalent Safety for Transportation and Packaging of Radioactive Materials. WHC-SD-TP-RPT-001, Rev. 0, Westinghouse Hanford Company, Richland, Washington.

WHC-CM-2-14, Hazardous Material Packaging and Shipping, Westinghouse Hanford Company, Richland, Washington. 
HNF-SD-TP-SEP-063, Rev. 0

\subsection{APPENDIX: CHECKLIST FOR REVIEW}

\section{CHECKLIST FOR REVIEW}

Document Reviewed: 327 Building Casks Risk Evaluation

Scope of Review: entire document

Yes No NA

[][]$[x)^{*}$

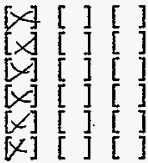

[x] [ ] [ ]

[X][ ] [ ]

[A] [ ] [ ]

$[x][][]$

[४] [ ] [ ]

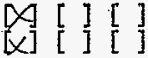

$[x][][]$

$[x][][]$

Previous reviews complete and cover analysis, up to scope of this review, with no gaps.

Problem completely defined.

Accident scenarios developed in a clear and logical manner. Necessary assumptions explicitly stated and supported. Computer codes and data files. documented.

Data used in calculations explicitly stated in document.

Data checked for consistency with original source information as applicable.

Mathematical derivations checked including dimensional consistency of results.

Models appropriate and used within range of validity or use outside range of established validity justified.

Hand calculations checked for errors. Spreadsheet results should be treated exactly the same as hand calculations.

Software input correct and consistent with document reviewed.

Software output consistent with input and with results reported in document reviewed.

Limits/criteria/guidelines applied to analysis results are appropriate and referenced. Limits/criteria/guidelines checked against references.

Safety margins consistent with good engineering practices.

Conclusions consistent with analytical results and applicable limits.

Results and conclusions address all points required in the problem statement.

Format consistent with appropriate NRC Regulatory Guide or other standards

[ ] [X]* Review calculations, comments, and/or notes are attached.

[X] [ ] [ ] Document approved.

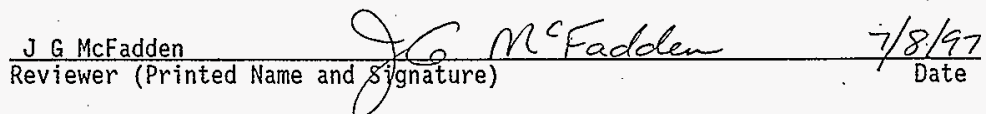

* Any calculations, comments, or notes generated as part of this review should be signed, dated and attached to this checklist. Such material should be 7 abeled and recorded in such a manner as to be intelligible to a technically qualified third party. 


\subsection{CONTAINMENT EVALUATION}

\subsection{INTRODUCTION}

The containment system consists of the PRTR Graphite Cask and the inner container. The inner container can be either a stainless steel tube $1.3 \mathrm{~cm}(0.50 \mathrm{in}$.$) or 1.9 \mathrm{~cm}(0.75 \mathrm{in}$.) in diameter or a DOT Specification 2R container per 49 CFR 178.360. An authorized exception to having an inner container would be a large solid item with fixed surface contamination. Items such as described can be placed directly into the cask. See Table B2-4.

\subsection{CONTAINMENT SOURCE SPECIFICATION}

The authorized radioactive contents of the PRTR Graphite Cask are described in Part B, Section 2.1. For conservatism, the containment analysis assumes that the inner container consists of the two 10-mil plastic bags, which are placed one inside the other.

\subsection{NORMAL TRANSPORT CONDITIONS}

\subsubsection{Conditions To Be Evaluated}

The structural performance of the cask was assessed for the Hanford Site normal conditions that are listed in Part B, Section 7.3.1.

\subsubsection{Containment Acceptance Criteria}

The acceptance criteria for the cask for NTC are that the cask shall retain the inner container and the inner container (plastic or glass vial) shall retain the radioactive material payload.

\subsection{ACCIDENT CONDITIONS}

\subsubsection{Conditions To Be Evaluated}

Accident conditions are evaluated for the PRTR Graphite Cask by radiological risk and dose consequence analyses. The radiological risk evaluation is given in Part B, Section 3.0, of this safety evaluation. The dose consequence and associated Transportation Hazard Index (THI) are given in Part B, Section 4.6.

\subsection{CONTAINMENT EVALUATION AND CONCLUSIONS}

\subsubsection{Normal Transport Conditions}

The PRTR Graphite Cask will provide the structural integrity necessary to transport the payload. The PRTR Graphite Cask has been used for shipments within the 300 Area for approximately 20 years. Prior approval for use of the cask to ship radioactive material was given in MG 137, Hazardous Materials Packaging and Shipping Manual, Rev. 1 (HEDL 1981). Although the PRTR Graphite Cask 
does not provide containment in the traditional sense, the contents are limited to dry, nondispersible items packaged in inner containers that are double wrapped in plastic. The cask provides shielding and, in conjunction with the inner container and plastic wrapping, prevents the release of the contents under the NTC evaluated in Part B, Section 7.0.

\subsubsection{Accident Conditions}

Based on the radiological risk evaluation in Part $B$, Section 3.0, and the dose consequence evaluation given in Part B, Section 4.6, the PRTR Graphite Cask, in conjunction with the other 327 Building casks, can be transported a maximum of $16.0 \mathrm{~km}(10.0 \mathrm{mi})$ per year while still remaining within the acceptable limits for onsite and offsite receptor doses.

\subsection{SUMMARY OF DOSE CONSEQUENCE RESULTS}

This section documents the dose consequence calculations used to support the THI evaluation for the 327 Building casks. Six casks are used to transport radioactive materials among several buildings in the 300 Area. The casks used for these transfers are the One-Ton Lab Cask, the Long Bore Cask, the Large Bore Cask, the Radioactive Waste Disposal Cask, the SERF Cask, and the PRTR Graphite Cask. The authorized contents for each of the casks was reviewed, and the PRTR Graphite Cask was found to have the lowest allowable radioactive inventory. The other 327 Building Casks IOne-Ton Lab Cask, Long Bore Cask, Large Bore Cask, Radioactive Waste Disposal Cask, and SERF Cask) have radioactive inventories that exceed that for the PRTR Graphite Cask; therefore, the dose consequences for the other five casks will be greater than that for the PRTR Graphite Cask. Because the PRTR Graphite Cask has to meet the highest level of requirements (i.e., those associated with a TH! of 1), the other five casks will also have to meet the requirements for a THI of 1 , and no additional analysis is required to demonstrate this.

Table B4- 1 shows the dose consequence results from each exposure pathway for the maximum authorized contents for the PRTR Graphite Cask. The table also shows the dose to each receptor, which is obtained by summing the dose contributions from each pathway. Because the offsite worker dose is greater than $25 \mathrm{rem}$, the packaging must be designed to THI 1 requirements. The criteria for a $\mathrm{THI}$ of 1 , as stated in WHC-CM-2-14:

"THI-1: This represents the highest level of hazard from the contents. A packaging system assigned this level transports material that has the potential of causing a dose consequence, to an individual, in excess of 25 rem at the Hanford site boundary if fully released."

Table B4-1. Summary of Doses (rem) for the Plutonium Recycle Test Reactor Graphite Cask.

\begin{tabular}{|l|c|c|}
\hline \multicolumn{1}{|c|}{ Exposure pathway } & $\begin{array}{c}\text { Hanford Site } \\
\text { worker at 3 m }\end{array}$ & $\begin{array}{c}\text { Public } \\
\text { receptor* }\end{array}$ \\
\hline External photon dose & 2.8 & $\mathrm{NA}$ \\
\hline External dose from $\beta$-particles & 5.0 & $\mathrm{NA}$ \\
\hline Inhalation and submersion from the airborne transport pathway & 2000 & 68 \\
\hline Total effective dose equivalent & 2000 & 68 \\
\hline
\end{tabular}

Note: 100 rem $=1$ sievert (Sv).

* This receptor is located $100 \mathrm{~m} \mathrm{~N}$ of the 300 Area. 


\subsubsection{Introduction and Overview}

Six casks are used to transport radioactive materials among several buildings in the 300 Area. The casks used for these transfers are the One-Ton Lab Cask, the Long Bore Cask, the Large Bore Cask, the Radioactive Waste Disposal Cask, the SERF Cask, and the PRTR Graphite Cask. The radioactive materials most frequently transported among buildings are irradiated Fast Flux Test Facility and Power Reactor and Nuclear Fuel Development Corporation fuel, spent $\mathrm{N}$ Reactor fuel, mixed oxide, metal oxide, activated structural materials from reactors, and cesium chloride capsules.

An estimate of the dose consequences for various exposure pathways is necessary to determine the THI for the 327 Building casks. Part B, Section 4.6.2, discusses the general methodology used to perform the dose consequence calculations. Part $B$, Section 4.6 .3 , addresses the source term, and Part B, Sections 4.6.4 through 4.6.9, summarize the results for various exposure pathways. The analysis assumes the casks will only be transported within the 300 Area.

\subsubsection{Dose Consequence Analysis Methodology}

IAEA (1990) defines a standardized approach for evaluating transportation packaging requirements, called the $Q$-system. The $Q$-system methods, as outlined in IAEA (1990), have been incorporated into the document, Report on Equivalent Safety for Transportation and Packaging of Radioactive Materials (Mercado 1994). This document (Mercado 1994) is used to demonstrate that onsite shipments meet onsite transportation safety requirements per WHC-CM-2-14.

In the Q-system, the following five exposure pathways are considered: (1) external exposure to photons, (2) external exposure to $\beta$-particles, (3) inhalation, (4) skin contamination and ingestion, and. (5) submersion in a cloud of gaseous isotopes. In special cases, such as $\alpha$-particle or neutron emitters, other exposure routes are considered. In some cases a pathway will be judged to be small with respect to the others, and consideration will be minimal. Modifications to the IAEA scenarios are incorporated to more closely describe the particular conditions of the shipment. Detailed calculations for the postulated accident are performed whenever possible. However, in some cases, the IAEA guide's (IAEA 1990) worst-case rules-of-thumb are used.

The Q-system was developed as an all-encompassing generalized methodology using only the isotope as the defining variable. In this report, the specifics of the package are considered. Some of the dose pathways may be considered incredible (frequency $<10^{6} / \mathrm{yr}$ ), and although these pathways are covered in the IAEA guide, they are disregarded in the analysis.

In the IAEA system, the $Q$-values that are calculated are the radionuclide activities corresponding to each exposure route that causes the individual to receive the effective dose equivalent limit. The minimum $Q$-values define the $A_{2}$ values for the shipped materiais. In the case of nondispersible materials (limited by the $A_{1}$ values), only the first two $Q$-values (based on exposure to external photon and external beta particles) are used. Note that for all radiation except neutrons, protons, and heavier charged particles (including $\alpha$-particles), 1 gray (Gy) $=1$ sievert (Sv), and $1 \mathrm{rad}=$ 1 rem.

There are two receptors of interest in the Q-system. They are the Hanford Site worker and the public receptor. The Hanford Site worker is assumed to be located about $3 \mathrm{~m}$ from the package. The public receptor is assumed to be located at the nearest point of public access.

\subsubsection{Source Term}

The authorized contents for the PRTR Graphite Cask are shown in Table B4-2. The external dose due to gamma exposure was calculated assuming the mixed fission products (MFP) consist of ${ }^{137} \mathrm{Cs}$, and the mixed activation products (MAP) consist of ${ }^{60} \mathrm{Co}$, which produce the highest gamma 
dose rates. The external dose due to beta particle exposure was calculated assuming the MFP consists of ${ }^{90} \mathrm{Sr} /{ }^{90} \mathrm{Y}$ and the MAP consists of ${ }^{59} \mathrm{Fe}$, which produce the highest beta dose rates. The inhalation dose was calculated assuming the MFP consists of ${ }^{90} \mathrm{Sr}$, the MAP consists of ${ }^{69} \mathrm{Fe}$, and the fissile material consists of $175 \mathrm{~g}(10.85 \mathrm{Ci})$ of ${ }^{239} \mathrm{Pu}$, which produce the highest inhalation dose. The use of $175 \mathrm{~g}$ of ${ }^{239} \mathrm{Pu}$ bounds the 2-Ci limit for $\alpha$ emitters for the PRTR Graphite Cask. Note that the alpha emitters and fissile material have a negligible impact on the external gamma and beta dose rates due to the high content of ${ }^{137} \mathrm{Cs},{ }^{90} \mathrm{Sr}$, and ${ }^{60} \mathrm{Co}$ assumed in the analyses.

Table B4-2. Plutonium Recycle Test Reactor Graphite Casks Radioactive Inventory.

\begin{tabular}{|l|l|}
\hline \multicolumn{1}{|c|}{ Radioactive material } & \multicolumn{1}{c|}{ Cask (Ci) } \\
\hline Fissile material and $\alpha$ emitters & 10.9 \\
\hline Mixed fission products & \\
\hline Mixed activation products & \\
\hline
\end{tabular}

"Mixed fission products; e.g., ${ }^{90} \mathrm{Sr},{ }^{137} \mathrm{Cs}$, etc.

${ }^{b}$ Mixed activation products; e.g. ${ }^{60} \mathrm{Co},{ }^{54} \mathrm{Mn},{ }^{59} \mathrm{Fe}$.

\subsubsection{External Dose Due to Photon (Gamma) Exposure}

The IAEA scenario assumes that a person is exposed to a damaged transport package following an accident. The shielding of the package is assumed to be completely lost in the accident. This analysis will be done assuming a person remains $3 \mathrm{~m}$ from the source for a period of 15 minutes.

The computer code ISO-PC (Rittmann 1995) was used to calculate the dose rate $3 \mathrm{~m}$ from the source. The fluence-to-dose conversion factors used were the anterior-to-posterior irradiation pattern as outlined in American National Standards Institute (ANSI) standard ANSI/ANS-6.1.1-1991 (ANS 1991).

It was conservatively assumed that the MFP $\left(375-\mathrm{Ci}\right.$ limit) consisted of ${ }^{137} \mathrm{Cs}$ and the MAP $(5-\mathrm{Ci}$ limit) consisted of ${ }^{60} \mathrm{Co}$ for this analysis. The other radioactive materials $(\alpha$ emitters, others, and fissile materials) will have a negligible contribution to the gamma dose rate compared to that from ${ }^{137} \mathrm{Cs}$ and ${ }^{60} \mathrm{Co}$.

The PRTR Graphite Cask has an internal diameter of $7.94 \mathrm{~cm}(3.125 \mathrm{in.})$ and a length of $62 \mathrm{~cm}$. $(24.5 \mathrm{in}$.). The source term was assumed to be homogeneously distributed throughout the cavity of the cask.

The payload for the PRTR Graphite Cask consists of mainly activated metal structural materials with a density of $7.86 \mathrm{~g} / \mathrm{cm}^{3}$. For this analysis, the source was taken to be iron with a density of $2.0 \mathrm{~g} / \mathrm{cm}^{3}$, which is about one-fourth the density of steel. The lower source density is conservative for this analysis because it results in higher dose rates due to reduced self-shielding and attenuation effects. Note that the results are not very sensitive to the selection of the source material.

The resulting dose rate from $1 S O-P C$ is $11 \mathrm{rem} / \mathrm{h}(0.11 \mathrm{~Sv} / \mathrm{h})$ at $3 \mathrm{~m}$ from the unshielded source. Therefore, the maximum total external gamma EDE for the Hanford Site worker is 2.8 rem $(0.028 \mathrm{~Sv})$ for a 15-minute exposure period. The ISO-PC input deck is included as Part B, Section 4.8.1. 


\subsubsection{External Dose Due to $\beta$-Particle Emitters}

Because of the limited range of $\beta$-particles relative to that of photons, a shielding factor is used by the IAEA to account for residual shielding from material such as package debris. Except for this factor, no effort is made to account for either self-shielding or shielding from an accurate model of the damaged package. Shielding and dose rate factors are graphed in the IAEA Safety Guide No. 7 (IAEA 1990) as a function of the maximum energy of the $\beta$-particle. The IAEA beta dose rate calculation methods are based on an individual located $1 \mathrm{~m}$ from the unshielded source.

This analysis assumes an individual remains at a distance of $3 \mathrm{~m}$ from the source for a 15 -minute exposure period. A factor will be applied to the dose rates calculated using the IAEA method to account for the difference between the $1-\mathrm{m}$ distance assumed in developing the shielding factors and the 3-m distance in this analysis. This factor was conservatively taken to be 0.333 [(1 m/3 m)] since the dose rate falls off between $1 / \mathrm{r}^{2}$ and $1 / \mathrm{r}$, where $r$ is the distance from the source. This also conservatively ignores any attenuation of the beta particles over the $3-\mathrm{m}$ distance.

Table B4-3 shows the $\beta$-particle dose calculations for the inventory in Table B4-2, assuming the MFP consists of ${ }^{90} \mathrm{Sr} /{ }^{90} \mathrm{Y}$ and the MAP consists of ${ }^{59} \mathrm{Fe}$. Note that ${ }^{239} \mathrm{Pu}$ and ${ }^{235} \mathrm{U}$ are not beta emitters. The total $\beta$-particle dose rate to the skin for an individual located $3 \mathrm{~m}$ from the source is $2.0 \times 10^{3} \mathrm{rem} / \mathrm{h}\left(2.0 \times 10^{1} \mathrm{~Sv} / \mathrm{h}\right)$. This results in a $\beta$-particle dose of $5.0 \times 10^{2} \mathrm{rem}(5.0 \mathrm{~Sv})$ to the skin for a 15-minute exposure. Because the tissue weighting factor for the skin is 0.01 (ICRP 1991), the whole body EDE is then 5.0 rem (0.05 Sv). Note that $98.9 \%$ of the $\beta$-particle dose is due to the highenergy $\left\{2.28 \mathrm{MeV}\right.$ ) $\beta$-particle emitted by ${ }^{90} \mathrm{Y}$.

Table B4-3. B-Particle Dose Rate for Beta Emitters Contributing $>0.01 \%$ to the Total Dose.

\begin{tabular}{|c|c|c|c|c|c|c|c|c|}
\hline Isotope & $\begin{array}{c}\text { Activity } \\
\text { (Ci) }\end{array}$ & $\begin{array}{l}\text { Activity } \\
(\mathrm{Bq})\end{array}$ & $\begin{array}{l}\text { Branching } \\
\text { ratio }\end{array}$ & $\begin{array}{c}E_{\max } \\
(\mathrm{MeV})\end{array}$ & $\begin{array}{c}\text { Dose rate } \\
\text { factor }\end{array}$ & $\begin{array}{l}\text { Shielding } \\
\text { factor }^{\circ}\end{array}$ & $\begin{array}{c}\text { Dose rate } \\
(\mathrm{rem} / \mathrm{h})^{\mathrm{c}}\end{array}$ & $\%$ Dose \\
\hline${ }^{90} \mathrm{Sr}$ & $3.75 \mathrm{E}+02$ & $1.39 E+13$ & 1 & 0.54600 & $1.8 \mathrm{E}-04$ & 100 & $2.25 E+01$ & 1.15 \\
\hline${ }^{90} \mathrm{Y}$ & $3.75 E+02$ & $1.39 E+13$ & 0.99989 & 2.28390 & $3.1 \mathrm{E}-04$ & 2 & $1.94 \mathrm{E}+03$ & 98.85 \\
\hline \multicolumn{7}{|c|}{ Totals for beta emitters contributing $>0.01 \%$} & $1.96 E+03$ & 100.00 \\
\hline \multicolumn{7}{|c|}{ Totals for all beta emitters } & $1.96 \mathrm{E}+03$ & 100.00 \\
\hline
\end{tabular}

'Dose rate factor in units of Gy/h or Sv/h for a 1-m Ci source from IAEA (1990).

"Shielding factor from IAEA (1990).

'Note that a factor of 0.333 is applied to the dose rates to account for a source-to-receptor distance of $3 \mathrm{~m}$ for this analysis, versus the $1-\mathrm{m}$ distance assumed in the development of the dose rate factors from IAEA (1990).

IAEA, 1990, Explanatory Material for the IAEA Regulations for the Safe Transport of Radioactive Material, Safety Series No. 7, Second Edition (As Amended 1990), International Atomic Energy Agency, Vienna, Austria.

\subsubsection{Inhalation and Ingestion Dose}

Radioactive material may be inhaled following an accident due to resuspension or volatization of radioactive material released from the package. This section addresses the dose received by workers and the public due to exposure to airborne radioactivity during a postulated accident event.

4.6.6.1 Selection of Airborne Release Fraction. The U.S. Department of Energy (DOE) handbook, Airborne Release Fractions/Rates and Respirable Fractions for Nonreactor Nuclear Facilities (DOE 1994), was reviewed to identify applicable airborne release fractions (ARF) and respirable fractions (RF) for the authorized contents of the 327 Building casks. The PRTR Graphite Cask is only 
authorized to transport irradiated structural materials or encapsulated solid materials. DOE (1994) identifies a bounding ARF $\times$ RF of $1 \times 10^{-3}$ for contaminated noncombustible materials not undergoing brittle fracture during shock vibration. This is a conservative airborne release fraction for the cask. contents considering that the authorized contents specify that "All materials shall be enclosed in an inner container. The type of inner containment. shall be sufficient to contain the item and prevent spread of removable contamination." Although the casks have not been analyzed to withstand hypothetical accident conditions, the inner container and the thick lead walls of the casks will likely prevent any catastrophic loss of the cask contents: The accident scenario envisioned for this analysis is an energetic event causing a loss of the cask closure lid, which exposes the cask contents and results in the radioactivity becoming airborne. No credit is taken for any containment provided by the inner container or the cask.

The ARF $\times$ RF of $1 \times 10^{-3}$ is applied to the material at risk, which is assumed to be the entire cask radioactive inventory, to obtain the quantity of radioactive material that is made airborne for the postulated accident scenario. As mentioned in Part B, Section 4.6.3, the inhalation dose for the PRTR Graphite Cask is calculated assuming the MFP consists of ${ }^{90} \mathrm{Sr}$, the MAP consists of ${ }^{59} \mathrm{Fe}$, and the fissile material consists of $175 \mathrm{~g}(10.85 \mathrm{Ci})$ of ${ }^{239} \mathrm{Pu}$, which produce the highest inhalation dose. The accident release quantities are listed in Table B4-4.

Table B4-4. Accident Airborne Release Quantities, Ci.

\begin{tabular}{|l|c|}
\hline \multicolumn{1}{|c|}{ Nuclide } & $\begin{array}{c}\text { Plutonium Recycle Test } \\
\text { Reactor Graphite Cask }\end{array}$ \\
\hline${ }^{90} \mathrm{Sr} /{ }^{90} \mathrm{Y}$ & 0.375 \\
\hline${ }^{59} \mathrm{Fe}$ & 0.005 \\
\hline${ }^{239} \mathrm{Pu}$ & 0.011 \\
\hline
\end{tabular}

4.6.6.1.1 Discussion of Integrated Normalized Air Concentration Value (X/Q'). After the radioactive material becomes airborne, it is transported downwind and inhaled by onsite workers or the public. The concentration of this material is reduced, or diluted, as it is being transported due to atmospheric mixing and turbulence. $X / \mathrm{Q}^{\prime}\left(\mathrm{s} / \mathrm{m}^{3}\right)$ is used to characterize the dilution of the airborne contaminants during atmospheric transport and dispersion. It is equal to the time-integrated normalized air concentration at the receptor. $X / O^{\prime}$ is a function of the atmospheric conditions (i.e., wind speed, stability class) and the distance to the receptor.

Bounding $X / \mathrm{O}^{\prime}$ values are generated consistent with the methods described in Atmospheric Dispersion Models for Potential Accident Consequence Assessments at Nuclear Power Plants, Regulatory Guide 1.145 (NRC 1982). Because atmospheric conditions fluctuate, a bounding atmospheric condition is determined to be that condition that causes a downwind concentration of airborne contaminants that is exceeded only a small fraction of time because of weather fluctuations. Regulatory Guide 1.145 (NRC 1982) defines this fraction of exceedance as $0.5 \%$ for each sector or $5 \%$ for the overall Hanford Site. The Hanford Site is broken up into 16 sectors that represent 16 compass directions; i.e., S, SSW, SW, . . . ESE, SE, SSE. $X / Q^{\prime}$ values are generated for weather conditions that result in downwind concentrations exceeded only $0.5 \%$ of the time in the maximum sector or $5 \%$ of the time for the overall Site. These $X / Q^{\prime}$ values are also referred to as $99.5 \%$ maximum sector and $95 \%$ overall Site $X / Q^{\prime}$ values. The greater of these two values is called the bounding $X / Q^{\prime}$ ' value and is used to assess the dose consequences for accident scenarios. The bounding $X / Q^{\prime}$ value represents minimum dispersing conditions that result in maximum downwind concentrations; i.e., concentrations exceeded only a very small fraction of the time. This $X / Q^{\prime}$ value will therefore result in very conservative estimates of accident consequences. 
The $X / Q^{\prime}$ values in this report were generated using the GXO computer program, Version $3.1 \mathrm{C}$ (Hey 1993a, 1993b). The meteorological data used by GXO are in the form of joint frequency tables. The joint frequency data are the most recent data available; they are nine-year-averaged data (1983-1991) from the Hanford Site meteorology towers located in the 300 Area. The $X / Q^{\prime}$ ' values are generated using the methods described in Regulatory Guide 1.145 (NRC 1982) for a ground release with no credit taken for plume rise, plume meander, plume depletion, or any other models. This is conservative because all of these models reduce the airborne concentration at the downwind receptor locations.

Although we are interested in the dose to a Hanford Site worker at $3 \mathrm{~m}$, the dose to an onsite receptor located $100 \mathrm{~m}$ from the release point is calculated using the worst-case $X / Q^{\prime}$ value at $100 \mathrm{~m}$. This dose is then multiplied by a factor of 30 to obtain the dose to the Hanford Site worker at $1 \mathrm{~m}$ in accordance with IAEA (1990). This approach is taken because the Gaussian equation, along with the parameters used to calculate the $X / Q^{\prime}$ values, are only valid for distances of $100 \mathrm{~m}$ or greater. Although this analysis assumes the transport worker remains $3 \mathrm{~m}$ from the package, the inhalation portion of the transport worker dose is conservatively taken to be that calculated using the IAEA method for a worker located $1 \mathrm{~m}$ from the package.

The 327 Building casks will be transported within the 300 Area. The maximum $X / Q^{\prime}$ value for an onsite receptor is $4.21 \times 10^{-2} \mathrm{~s} / \mathrm{m}^{3}$ and occurs for an individual located $100 \mathrm{~m} \mathrm{~N}$ of the release point in the 300 Area.

The 300 Area is not a public exclusion area. Even though the roads may be closed during movement of the 327 Building casks, members of the public may be in the area. Therefore, it is conservatively assumed for this analysis that the public receptor is located $100 \mathrm{~m}$ from the release point in any compass direction. The maximum onsite and public receptor $X / Q^{\prime}$ value will therefore be the same, i.e., the maximum public receptor $X / Q^{\prime}$ value is $4.21 \times 10^{-2} \mathrm{~s} / \mathrm{m}^{3}$. The $G X Q$ input file for the maximum $X / O^{\prime}$ case is listed in Part $B$, Section 4.8.2. The title of the joint frequency file used by $G \times O$ is 300 AREA - $10 \mathrm{M}$ - Pasquill A - G (1983 - 1991 Average).

4.6.6.1.2 Inhalation and Submersion Dose Calculations. Because the GENII computer code Version 1.485 (Napier 1988) is the Site standard computer code for environmental release dose calculations, it was used to calculate the inhalation and submersion dose for the maximum onsite and public receptors. The airborne release quantities used in GENII are shown in Table B4-4. An example GENII input deck is listed in Part B, Section 4.8.3. The Worst Case Solubility class library was used, which is the most conservative library. The GENII libraries used were as follows:

- GENII Default Parameter Values (28-Mar-90 RAP)

- Radionuclide Library - Times $<100$ years (23-July-93 PDR)

- $\quad$ External Dose Factors for GENII in person Sv/yr per Bq/n (8-May-90)

- Worst Case Solubilities, Yearly Dose Increments (23-Jut-93 PDR).

The EDE from GENII for the inhalation and submersion pathways is $1.2 \times 10^{2}$ rem (1.2 Sv) for the maximum onsite receptor at $100 \mathrm{~m} \mathrm{~N}$ of the 300 Area. The inhalation dose contribution to the EDE is based on a 50-year dose commitment period. The maximum X/Q' value from GENII was $7.4 \times 10^{-2} \mathrm{~s} / \mathrm{m}^{3}$ for the maximum onsite receptor. The dose rates calculated by GENIl are proportional to the X/O' values. The $\mathrm{GXO}$ code calculates the $99.5 \%$ maximum sector and $95 \%$ overall Site $X / \mathrm{O}^{\prime}$ values consistent with Regulatory Guide 1.145 (NRC 1982) methods, while GENII is inconsistent with Regulatory Guide 1.145 methods. As mentioned in the previous section, the maximum onsite receptor $X / Q^{\prime}$ value from $G X Q$ is $4.21 \times 10^{.02} \mathrm{~s} / \mathrm{m}^{3}$. Therefore, the EDE for the inhalation and submersion pathways is $6.8 \times 10^{1} \mathrm{rem}\left(6.8 \times 10^{-1} \mathrm{~Sv}\right)$ for the maximum onsite receptor at $100 \mathrm{~m}$ using the $\mathrm{GXO}$ $X / Q^{\prime}$ value. This value was obtained by multiplying the GENII dose rate by the ratio of the $G \times O X / O^{\prime}$ value to the GENII $X / Q^{\prime}$ value. Therefore the maximum public receptor dose is $6.8 \times 10^{1} \mathrm{rem}$ $\left(6.8 \times 10^{-1} \mathrm{~Sv}\right)$. 
To compensate for the fact that the onsite dose is calculated at a source-to-receptor distance of $100 \mathrm{~m}$, this dose is multiplied by a factor of 30 to obtain the dose to the transport worker at $1 \mathrm{~m}$ in accordance with IAEA (1990). Although this analysis assumes the transport worker remains $3 \mathrm{~m}$ from the package, the inhalation portion of the transport worker dose is conservatively taken to be that calculated using the IAEA method for a worker located $1 \mathrm{~m}$ from the package. This results in an EDE of $2.0 \times 10^{3} \mathrm{rem}(20.0 \mathrm{~Sv}$ ) for the Hanford Site worker. Table B4-5 shows the doses for the postulated accident scenario.

Table B4-5. Inhalation and Submersion Dose (rem).

\begin{tabular}{|l|c|c|}
\cline { 2 - 3 } \multicolumn{1}{c|}{} & $\begin{array}{c}\text { Hanford worker } \\
\text { (at } 3 \mathrm{~m} \text { ) }\end{array}$ & Public receptor* \\
\hline Effective dose equivalent & 2000 & 68 \\
\hline
\end{tabular}

Note: $100 \mathrm{rem}=1 \mathrm{~Sv}$.

* This receptor is located $100 \mathrm{~m} \mathrm{~N}$ of the 300 Area.

4.6.6.1.3 Ingestion and Ground Shine Dose. The other potential internal exposure pathway for the public receptor is the ingestion pathway. Exposure through the ingestion pathway occurs when radioactive materials that have been deposited offsite during passage of the plume are ingested either by eating crops grown in, or animals raised on, contaminated soil or through drinking contaminated water. There are DOE; DOE, Richland Operations Office; state; and federal programs in place to prevent ingestion of contaminated food in the event of an accident (RL 1994, WSDOH 1993, WS 1994, EPA 1992). The primary determinant of exposure from the ingestion pathway is the effectiveness of public health measures (i.e., interdiction) rather than the severity of the accident itself. The ingestion pathway, if it occurs, is a slow-to-develop pathway and is not considered an immediate threat to an exposed population in the same sense as airborne plume exposures.

The ground shine pathway is an additional potential external exposure pathway for the public receptor. Ground shine refers to the external dose received by a person standing on ground contaminated by radioactive materials deposited during passage of the airborne radioactive plume. Similar to the ingestion pathway, the primary determinant of exposure from the ground shine pathway is the effectiveness of public health measures (i.e., interdiction) rather than the severity of the accident itself. The ground shine pathway is a slow-to-develop pathway and is not considered an immediate threat to an exposed population in the same sense as airborne plume exposures.

Because of the large radioactive inventory contained in the casks, it is argued that in the event of an accident scenario that results in the release of a large portion of the inventory, interdictive measures (RL 1994, WSDOH 1993, WS 1994, EPA 1992) would be taken to prevent ingestion of contaminated food and exposure through the ground shine pathway. Therefore, the ingestion and ground shine pathway doses were not calculated in this report.

\subsubsection{Skin Contamination and Ingestion Dose}

In the IAEA guide (IAEA 1990), it is assumed that $1 \%$ of the package contents are spread over an area of $1 \mathrm{~m}^{2}$ and handling of debris results in contamination of the hands to $10 \%$ of this level. It is further assumed that the worker is not wearing gloves but that he recognizes the possibility of contamination and washes his hands within five hours. The effective dose equivalent to the skin received by the individual is estimated from a graph provided in the IAEA guide.

The IAEA scenario for the uptake of activity due to ingestion of the material assumes that the person ingests all of the contamination from $10 \mathrm{~cm}^{2}$ of skin over a 24-hour period. Because the dose 
per unit uptake via inhalation is generally the same order or larger than that via ingestion, the inhalation pathway will normally be limiting for internal contamination due to $\beta$-ray emitters. In particular, if the skin contamination dose is much larger than the inhalation dose, the ingestion pathway is not considered.

Both these pathways are ordinarily neglected when calculating the dose consequences from an onsite transportation accident. The transportation workers are trained in the appropriate response to protect themselves from experiencing unnecessary radiation exposure, including preventing skin contamination and ingestion.

\subsubsection{Submersion Dose Due to Gaseous Vapor}

This exposure pathway is caused by submersion in a cloud of gaseous isotopes that are not taken into the body. A rapid release of $100 \%$ of the package contents is assumed. The IAEA guide (IAEA 1990 ) concentrates entirely on releases within confined structures. No guidance is given for outside releases.

There are no gaseous vapors present in the cask; therefore, this exposure pathway is not applicable.

\subsubsection{Special Considerations}

Alpha particle emitters are not of significance in the material considered in this report. The alpha particle emitters are of a low concentration, and their effect will be through the mechanism of inhalation that has been considered separately. Therefore, they are not addressed in this report. The quantity of radon present in the fuel is insignificant; therefore, radon is not addressed in this report.

The fuel (e.g., plutonium) contained in the casks emits neutrons through $(\alpha, n)$ and spontaneous fission reactions. These neutron emitters will contribute to the dose received by the Hanford Site worker, but will have a negligible impact on the public receptor. A conservative estimate of the neutron dose was made using the method described in Nelson (1996). The results indicate that the neutron dose contribution is negligible compared to the gamma dose due to the large MFP and MAP inventory. Therefore, the neutron dose was not calculated separately in this report.

Bremsstrahlung has been included in the consideration of photon effects, and the effects of short-lived daughter products have been included in all of the calculations. Where these isotopes are significant, they are assumed to be in equilibrium with their longer-lived parent isotopes.

\subsubsection{Total Dose}

Table B4-1 in Part B, Section 4.6, shows the dose from each exposure pathiway.

\subsection{REFERENCES}

ANS, 1991, Neutron and Gamma-Ray Fluence-to-Dose Factors, ANSI/ANS-6.1.1-1991, American Nuclear Society, La Grange Park, Illinois.

DOE, 1994, Airborne Release Fractions/Rates and Respirable Fractions for Nonreactor Nuclear Facilities, DOE-HDBK-3010-94, U.S. Department of Energy, Washington, D.C. 
DOE, 1992, Hazard Categorization and Accident Analysis Techniques for Compliance with DOE Order 5480.23, Nuclear Safety Analysis Reports, DOE-STD-1027-92, U.S. Department of Energy, Washington, D.C.

DOE, 1988, Radiation Protection for Occupational Workers, DOE Order 5480.11, U.S. Department of Energy, Washington, D.C.

EPA, 1992, Manual of Protective Action Guides and Protective Actions for Nuclear Incidents, U.S. Environmental Protection Agency, Washington, D.C.

HEDL, 1981, Hazardous Materials Packaging and Shipping Manual, MG 137, Rev. 1, Hanford Engineering Development Laboratory, Richland, Washington.

Hey, B. E., 1993a, GXQ Program Users' Guide, WHC-SD-GN-SWD-30002, Rev. O, Westinghouse Hanford Company, Richland, Washington.

Hey, B. E., 1993b, GXQ Program Verification and Validation, WHC-SD-GN-SWD-30003, Rev. 0, Westinghouse Hanford Company, Richland, Washington.

IAEA, 1990, Explanatory Material for the IAEA Regulations for the Safe Transport of Radioactive Material, Safety Series No. 7, Second Edition (As Amended 1990), International Atomic Energy Agency, Vienna.

ICRP, 1991, International Commission on Radiological Protection, Annals of the ICRP, Publication 60. 1991, International Commission on Radiological Protection, New York, New York.

Mercado, J. E., 1994, Report on Equivalent Safety for Transportation and Packaging of Radioactive Materials, WHC-SD-TP-RPT-001, Rev. O, Westinghouse Hanford Company, Richland, Washington.

Napier, B. A., et al., December 1988, GENII - The Hanford Environmental Radiation Dosimetry Software System, PNL-6584, Vol. 1, UC-600, Pacific Northwest Laboratory, Richland, Washington.

Nelson, J. V., 1996, Estimation of Neutron Dose Rates from Nuclear Waste Packages, (internal memo 8M730-JVN-96-007 to J. R. Green, March 8), Westinghouse Hanford Company, Richland, Washington.

NRC, 1982, Atmospheric Dispersion Models for Potential Accident Consequence Assessments at Nuclear Power Plants, Regulatory Guide 1.145, U.S. Nuclear Regulatory Commission, Washington, D.C.

Rittmann, P. D., 1995, ISO-PC Version 1.98 - User's Guide, WHC-SD-WM-UM-030, Rev. O, Westinghouse Hanford Company, Richland, Washington.

RL, 1994, Emergency Implementation Procedures, DOE-0223, U.S. Department of Energy, Richland Operations Office, Richland, Washington.

WHC-CM-2-14, Hazardous Material Packaging and Shipping, Westinghouse Hanford Company, Richland, Washington.

WHC-CM-4-46, Nonreactor Facility Safety Analysis Manual, Westinghouse Hanford Company, Richland, Washington.

WHC, 1995, Packaging Design Criteria, Transfer and Disposal of Long-Length Equipment, Hanford Tank Farm Complex, WHC-SD-TP-PDC-020, Rev. 2, Westinghouse Hanford Company, Richland, Washington. 
WSDOH, 1993, "Response Procedures for Radiation Emergencies," Appendix A, Protective Action Guides, Washington State Department of Health, Olympia, Washington.

WS, 1994, "Fixed Nuclear Facility Emergency Response Procedure," Section 10.6 - Department of Agriculture, Washington State.

\subsection{APPENDICES}

\subsubsection{ISO-PC Input File}

0 2 PRTR Cask Side Dose Rate - Unshielded

Cyl. Source Geom - Dose Rate at $3 \mathrm{~m}$ Side Surface

\&Input Next $=1$, ISpec $=3, \mathrm{IGeom}=7, \quad \mathrm{CONC}=0, \mathrm{SFACT}=1, \mathrm{DUNIT}=7$,

NTheta $=30, \mathrm{NPsi}=20, \mathrm{NShld}=1, \mathrm{JBuf}=1, \mathrm{OPT} \mid \mathrm{ON}=1$,

Sith $=62.2$,

$\mathrm{Y}=31.1$,

$T(1)=3.969$

$X=303.969$,

WEIGHT(335) $=375$

WEIGHT(336) $=354.75$

WEIGHT(472) $=5, \quad \&$

1Soure 92.0

End of Input

\&lnput Next $=6 \&$ 


\subsubsection{GXO Input File}

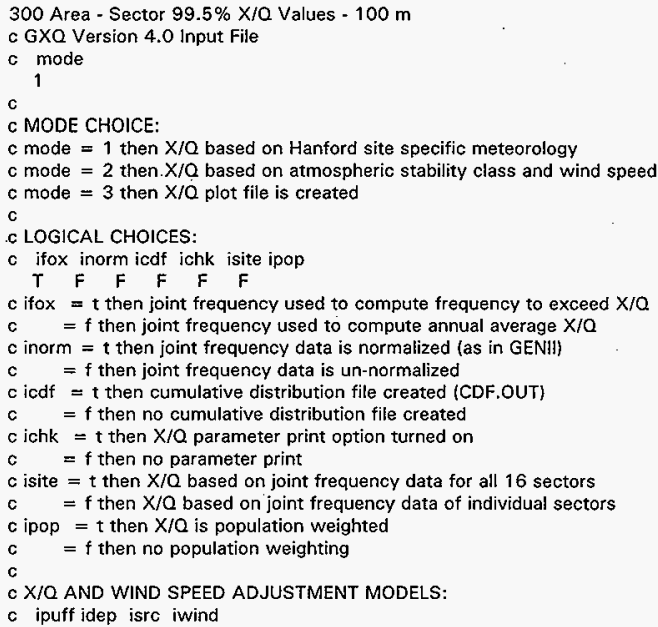


HNF-SD-TP-SEP-063, Rev. 0

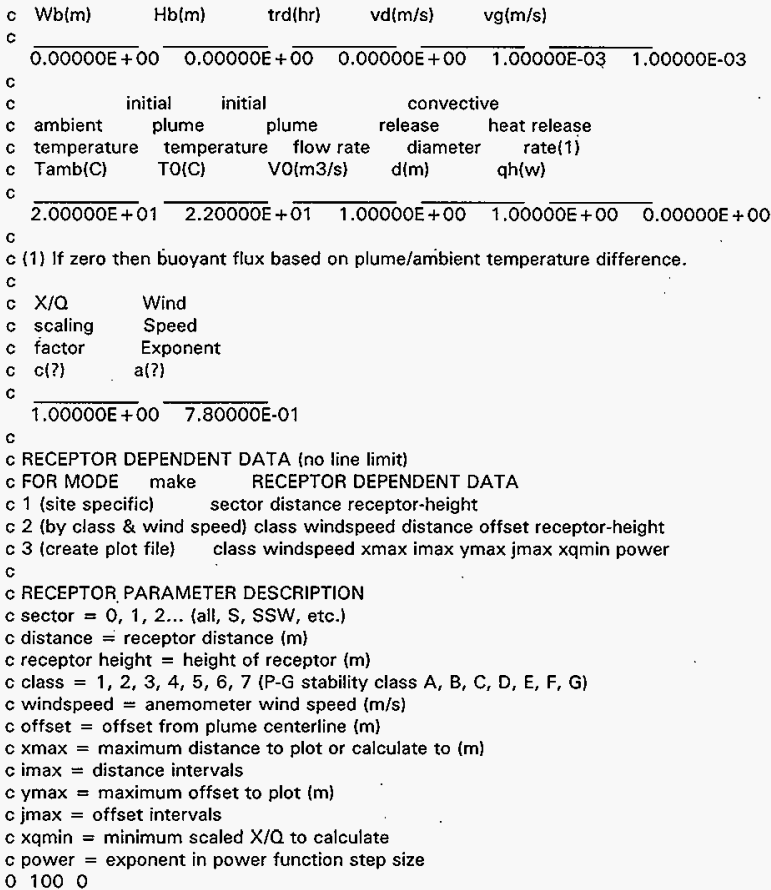




\subsubsection{GENII Input File}

\#\#\#\#\#\#\#\#\#\#\#\#\#\#\#\#\#\#\#\#\#\#\#\#\# Program GENIl Input File \#\#\#\#\#\#\#\#\#\#\#\#8 Jul 88 \#\#\#\#

Title: PRTR Graphite Cask - 300 Area Onsite - Inhalation \& Submersion

ISAMPLIG-AIR.AC

Created on 01-22-1990 at 07:30

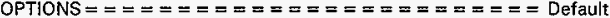

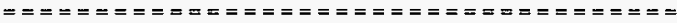

F Near-field scenario? (Far-field) NEAR-FIELD: narrowly-focused

$F$ Population dose? (Individual) release, single site

T Acute release? (Chronic) FAR-FIELD: wide-scale release,

Maximum Individual data set used multiple sites Complete

$$
\text { Complete }
$$

TRANSPORT OPTIONS $=\overline{=}=\overline{=}=\overline{=}=\overline{=}$ Section EXPOSURE PATHWAY OPTIONS $===\bar{z}=$ Section

T Air Transport 1 F Finite plume, external $\mathbf{5}$

F Surface Water Transport $2 \mathrm{~T}$ Infinite plume, external 5

$F$ Biotic Transport (near-field) 3,4 F Ground, external

$F$ Waste Form Degradation (near) 3,4 F Recreation, external 5

$$
T \text { Inhalation uptake } \quad 5,6
$$

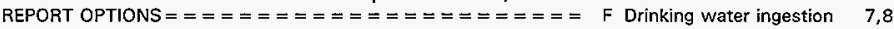

$T$ Report AEDE only

F Aquatic foods ingestion 7,8

F Report by radionuclide

F Report by exposure pathway

F Terrestrial foods ingestion 7,9

F Animal product ingestion 7,10

$F$ Debug report on screen

$F$ Inadvertent soil ingestion

INVENTORY \#\#\#\#\#\#\#\#\#\#\#\#\#\#\#\#\#\#\#\#\#\#\#\#\#\#\#\#\#\#\#\#\#\#\#\#\#\#\#\#\#\#\#\#\#\#\#\#\#\#\#\#\#\#\#\#\#\#\#\#\#\#\#\#\#\#\#\#

4 Inventory input activity units: $(1-\mathrm{pCi} \quad 2-\mathrm{uCi} \quad 3-\mathrm{mCj} \quad 4-\mathrm{Ci} \quad 5-8 \mathrm{q})$

o Surface soil source units $(1-\mathrm{m} 2.2-\mathrm{m} 33 \cdot \mathrm{kg})$

Equilibrium question goes here

---------Release Terms-----|-------Basic Concentrations--------|

Use when| transport selected | near-field scenario, optionally

Release I Surface Buried | Surface Deep Ground Surfacel

Radio- Air Water Waste |Air Soil Soil Water Water |

nuclide $|/ y r \quad / y r \quad / m 3 \quad| / m 3$ Junit $/ \mathrm{m} 3 \quad / L \quad h \quad$

SR90 $3.75 \mathrm{E}-01$

Y 90 3.75E-01

FE59 5.00E-03

PU239 1.09E-02

-.----.-Derived Concentrations---.-|

Use when| measured values are known I

(1)

Release |Terres. Animal Drink Aquatic|

Radio- Plant Product Water Food |

nuclide $\mid / \mathrm{kg} \quad / \mathrm{kg} / \mathrm{L} \quad / \mathrm{kg} \quad$ |

-

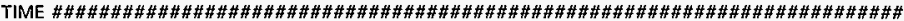

1 Intake ends after (yr)

50 Dose calc. ends after $(y r)$

1 Release ends after (yr)

0 . No. of years of air deposition prior to the intake period

0 No. of years of irrigation water deposition prior to the intake period

FAR-FIELD SCENARIOS (IF POPULATION DOSE) \#\#\#\#\#\#\#\#\#\#\#\#\#\#\#\#\#\#\#\#\#\#\#\#\#\#\#\#\#\#\#\#\#\#\#

$0 \quad$ Definition option: 1-Use population grid in file POP.IN

2-Use total entered on this line

NEAR-FIELD SCENARIOS $\# \# \# \# \# \# \# \# \# \# \# \# \# \# \# \# \# \# \# \# \# \# \# \# \# \# \# \# \# \# \# \# \# \# \# \# \# \# \# \# \# \# \# \# \# \# \# \# \# \# \# \# \# \# \# \# \#$

Prior to the beginning of the intake period: (yr)

When was the inventory disposed? (Package degradation starts)

When was LOIC? (Biotic transport starts)

Fraction of roots in upper soil (top $15 \mathrm{~cm}$ ) 
HNF-SD-TP-SEP-063, Rev. 0

- Fraction of roots in deep soil

$0 \quad$ Manual redistribution; deep soil/surface soil dilution factor

$0 \quad$ Source area for external dose modification factor $(\mathrm{m} 2)$

TRANSPORT \#\#\#\#\#\#\#\#\#\#\#\#\#\#\#\#\#\#\#\#\#\#\#\#\#\#\#\#\#\#\#\#\#\#\#\#\#\#\#\#\#\#\#\#\#\#\#\#\#\#\#\#\#\#\#\#\#\#\#\#\#\#\#\#\#\#\#

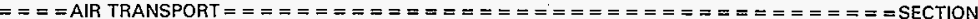

$1====$

0-Calculate PM $\quad 10 \quad$ Release type (0-3)

3 Option: 1 -Use chi/Q or PM value $\mid F$ Stack release (T/F)

2-Select MI dist \& dir $10 \quad$ Stack height $(\mathrm{m})$

3-Specify MI dist \& dir $10 \quad$ Stack flow (m3/sec)

1 Chi/Q or PM value $10 \quad$ Stack radius $(m)$

$14 \quad$ Ml sector index $(1=\mathrm{S}) \quad 10 \quad$ Effluent temp. (C)

100. Mi distance from release point $(\mathrm{m}) \mid \mathrm{O}$ Building $x$-section $(\mathrm{m} 2)$

$T$ Use jf data, (T/F) else chi/Q grid/O Building height (m)

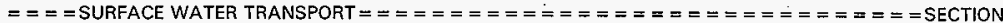

$2====$

Mixing ratio model: 0 -use value, 1 -river, 2-lake

Mixing ratio, dimensionless

Average river flow rate for: $M I X F L G=0(\mathrm{~m} 3 / \mathrm{s}), M I X F L G=1,2(\mathrm{~m} / \mathrm{s})$,

Transit time to irrigation withdrawi location (hr)

If mixing ratio model $>0$ :

Rate of effluent discharge to receiving water body $(\mathrm{m} 3 / \mathrm{s})$

Longshore distance from release point to usage location $(\mathrm{m})$

Offshore distance to the water intake $(\mathrm{m})$

Average water depth in surface water body $(\mathrm{ml}$

Average river width ( $\mathrm{m}), \mathrm{MIXFLG}=1$ only

Depth of effluent discharge point to surface water $(\mathrm{m})$, lake only $3== \pm==$

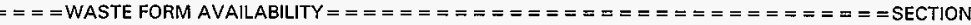

Waste form/package half life, (yr)

Waste thickness, (m)

Depth of soil overburden, $m$

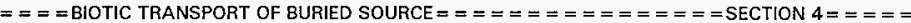

Consider during inventory decay/buildup period (T/F)?

Consider during intake period $(\mathrm{T} / \mathrm{F})$ ? | 1-Arid non agricultural

Pre-Intake site condition. 2-Humid non agricultural

| 3-Agricultura!

EXPOSURE \#\#\#\#\#\#\#\#\#\#\#\#\#\#\#\#\#\#\#\#\#\#\#\#\#\#\#\#\#\#\#\#\#\#\#\#\#\#\#\#\#\#\#\#\#\#\#\#\#\#\#\#\#\#\#\#\#\#\#\#\#\#\#\#\#\#\#

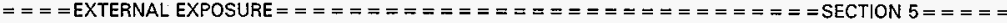
Exposure time:

Plume (hr)

I Residential irrigation:

Soil contamination (hr) 10 Source: 1-ground water

Swimming (hr)

Boating (hr)

2-surface water

Shoreline activities (hr) 10 Duration (mo/yr)

Shoreline type: (1-river, 2-lake, 3-ocean, 4-tidal basin)

Transit time for release to reach aquatic recreation (hr)

1.0 Average fraction of time submersed in acute cloud (hr/person hr)

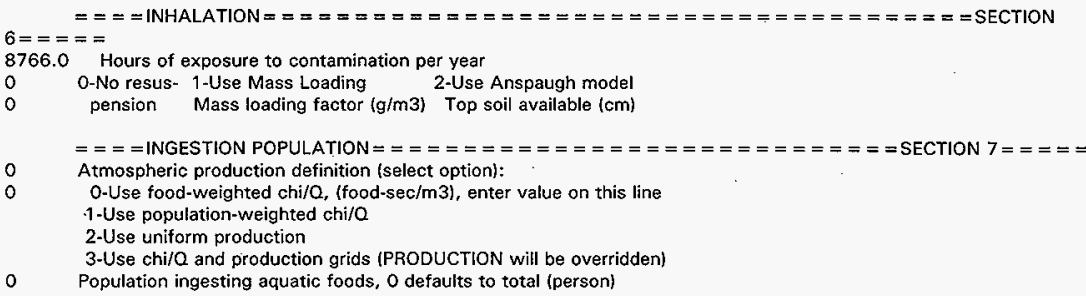




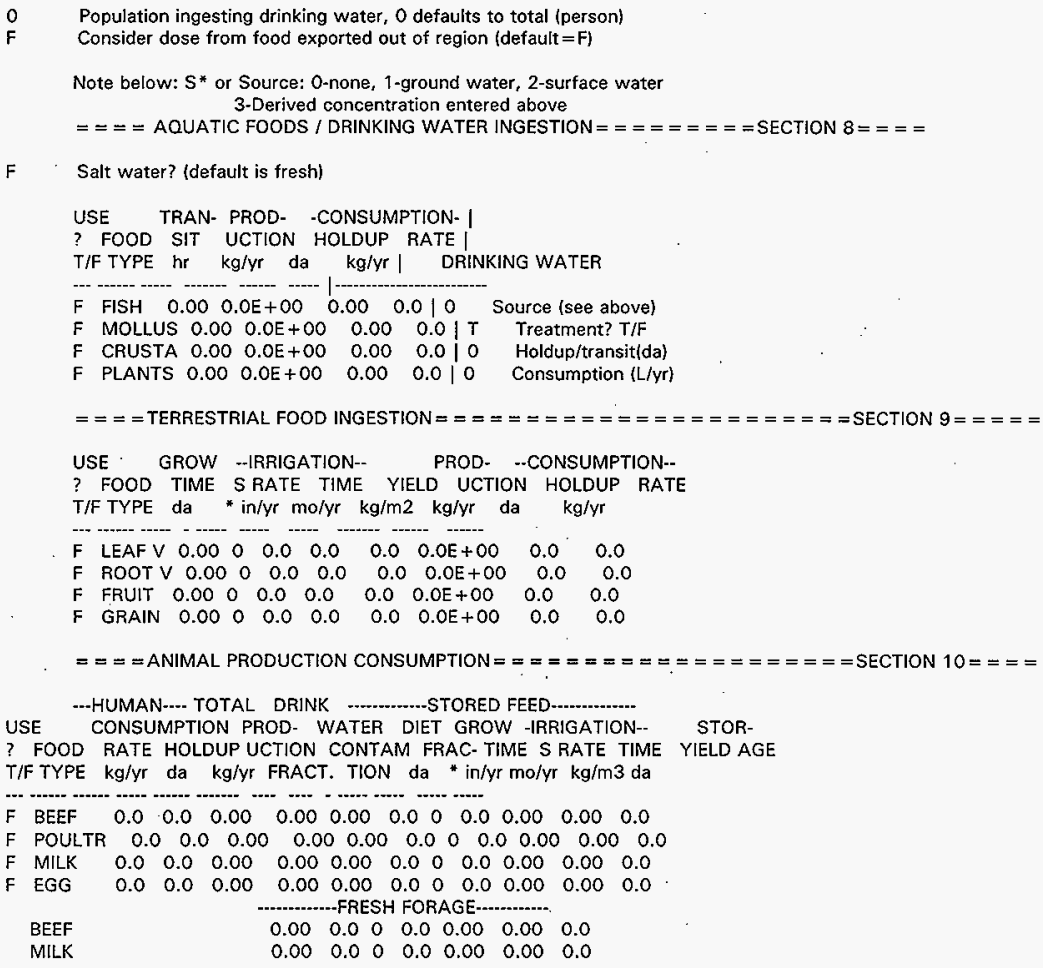




\subsubsection{Checklist for Technical Peer Review}

\section{CHECKLIST FOR REVIEH}

Document Reviewed: THI for the 327 Building Family of Casks

Scope of Review: entire document

Yes No NA

[][][V] * Previous reviews complete and cover analysis, up to scope of this review, with no gaps.

[J. [ ] [ ] Problem completely defined.

[] [ [ ] Accident scenarios developed in a clear and logical manner. Necessary assumptions explicitiy stated and supported.

Computer codes and data files documented.

Data used in calculations explicitly stated in document.

Data checked for consistency with original source information as applicable.

[1 [ ] [ ] Mathematical derivations checked inciuding dimensional consistency of results.

[1 [ ] [ ] Models appropriate and used within range of validity or use

- outside range of established validity justified.

[ $][$ [ [ ] Hand calculations checked for errors. Spreadsheet results should be treated exactly the same as hand calculations.

[J [ [ ] Software input correct and consistent with document reviewed.

$[\because][][$ Software output consistent with input and with results reported in document reviewed.

[J [ ] [ ] Limits/criteria/guidelines applied to analysis results are appropriate and referenced. Limits/criteria/guidelines checked against references.

[न] [ ] [ ] Safety margins consistent with good engineering practices: Conclusions consistent with analytical results and applicable Timits.

[J] [ [ ] Results and conclusions address al] points required in the problem statement.

[j] [ ] [ ] Format consistent with appropriate NRC Regulatory Guide or other standards

[ ] [J** Review calculations, comments, and/or notes are atțached.

[M [ ] [ ] Document approved.

J. G. McFadden

Reviewer (Printed Name and Signature)

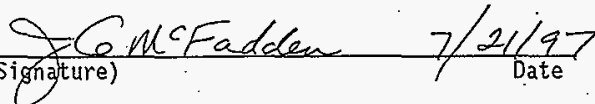

* Any calculations, comments, or notes generated as part of this review should be signed, dated and attached to this checklist. Such material should be labeled and recorded in such a manner as to be intelligible to a technically qualified third party. 
4.8.5 HEDOP Review Checklist

\author{
HEDOP REVIEH CHECKLIST \\ for \\ Radiological and Konradiological Release Calculations
}

Document: Transportation Hazard Index (THI) Analys is for the 327 Building Casks SEPs," May 9, 1997.

Scope of Review: Inhalation/Air Submersion Dose Calculations

YES NO* N/A

[x] [ ] [ ] 1. A detailed technical review and approval of the environmental transport and dose calculation portion of the analysis has been performed and documented.

[ ] [ ] [x] 2. Detailed technical review(s) and approval(s) of scenario and release determinations have been performed and documented.

[ $][x] \quad[$ ] 3. HEDOP-approved code(s) were used.

$[x][] \quad[]$ 4. Receptor locations were selected according to HEDOP recommendations.

[x] [ ] [ ] 5. All applicable environmental pathways and code options

[x] [ ] [ ] 6. Hanford site data were used.

$[x]$ [ $][j, 7$. Model adjustments external to the computer program were justified and performed correctiy.

[x] [ ] [ ] 8. The analysis is consistent with HEDOP recommendations.

[x] [ ] 9. Supporting notes, calculations, comments, comment resolutions, or other information is attached. (Use the "Page 1 of $X "$ page numbering format and sign and date each added page.)

[x] [ ] 10. Approval is granted on behalf of the Hanford Environmental Dose Overview Panet.

* Al1 "NO" responses must be explained and use of nonstandard methods justified.

Kathy Rhoads

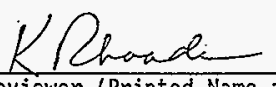

HEDOP-Approved Reviewer (Printed Name and Signature)

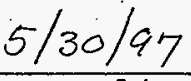

COMMENTS (add additional signed and dated pages if necessary):

Item 3: GXQ used for air transport calculations; GENII results are included for comparison. 


\subsection{SHIELDING EVALUATION}

\subsection{INTRODUCTION}

This shielding evaluation supports the shipment of activated materials and fuel components in the PRTR Graphite Cask within the Hanford 300 Area.

\subsection{DIRECT RADIATION SOURCE SPECIFICATION}

The source term for the materials transported by the cask will be variable and, therefore, is described generally and evaluated on the basis of bounding conditions for gamma and neutron emissions. The source term evaluated for shielding is shown in Table B5-1. Isotopes other than those listed may be shipped in the cask, but the surface dose rate is limited to those shown in Part B, Section 5.4 , in all cases.

Table B5-1. Maximum Allowable Shielding Source Term.

\begin{tabular}{|l|c|c|l|}
\hline \multirow{2}{*}{ Material } & \multicolumn{2}{|c|}{ Activity limit } & \multicolumn{2}{|c|}{ Comments } \\
\cline { 2 - 3 } & $\mathrm{TBq}$ & $\mathrm{Ci}$ & \\
\hline $\begin{array}{l}\text { Fissile materials and } \alpha \\
\text { emitters* }\end{array}$ & 0.401 & 10.9 & $\begin{array}{l}\alpha \text {-emitting materials, except for } 175 \mathrm{~g}(10.85 \mathrm{Ci}) \\
\text { 239 } \mathrm{Pu} \text {, were not considered for shielding. The } \\
\text { neutron dose rate from }{ }^{239} \mathrm{Pu} \text { bounds the neutron } \\
\text { dose rate for all other materials in this category. }\end{array}$ \\
\hline Mixed fission products & 13.9 & 375 & Considered to be all ${ }^{137} \mathrm{Cs}$ for shielding \\
\hline Mixed activation products & 0.185 & 5.00 & Considered to be all ${ }^{60} \mathrm{Co}$ for shielding \\
\hline
\end{tabular}

* Fissile/fissionable materials limited by criticality safety as shown in Part B, Section 2.1.1.

\subsubsection{Gamma Source}

The gamma source term evaluated is a mixed inventory of ${ }^{60} \mathrm{Co}$ and ${ }^{137} \mathrm{Cs}$ with an equilibrium amount of the ${ }^{137} \mathrm{Cs}$ daughter, ${ }^{137 \mathrm{~m}} \mathrm{Ba}$. Although the mixed inventory may have additional gamma sources, these are bounded by the ${ }^{60} \mathrm{Co}$ and ${ }^{137} \mathrm{Cs}$ terms and were not considered separately.

\subsubsection{Beta Source}

Beta particles originating in the source do not contribute directly to the dose rate outside the casks because of the shielding provided. Although the bremsstrahlung radiation produced by the deceleration of the beta particles in the source is a potential contribution to the source, the contribution is minimal and bounded by the gamma source term discussed in Part B, Section 5.1.2. For the isotopes evaluated, however, bremsstrahlung was considered.

\subsubsection{Neutron. Source}

The neutron source term for the mixed materials inventory was calculated using the ORIGEN2 (Schmittroth 1994) computer code. The worst-case neutron source term was found to be from ${ }^{239} \mathrm{Pu}$ 
and was found to occur prior to any decay being considered. Although ${ }^{235} \mathrm{U}$ was considered, the neutron source term is negligible compared to ${ }^{239} \mathrm{Pu}$. The source term is shown in Table $\mathrm{B} 5-2$, and the ORIGEN2 input file is included in Part B, Section 5.8.

Table B5-2. Neutron Source Term for $175 \mathrm{~g}$ of ${ }^{239} \mathrm{Pu}$

\begin{tabular}{|l|l|}
\hline \multicolumn{1}{|c|}{ Component of source } & \multicolumn{1}{|c|}{ Source strength (neutrons/s) } \\
\hline$(\alpha, n)$ & $7.927 \mathrm{E}+03$ \\
\hline Spontaneous fission & 3.967 \\
\hline Total & $7.931 \mathrm{E}+03$ \\
\hline
\end{tabular}

The cesium capsule inventory has no neutron emitters.

\subsection{SUMMARY OF SHIELDING PROPERTIES OF MATERIALS}

The shielding in the PRTR Graphite Cask is provided by lead encased in a stainless steel shell. The default densities for iron and lead provided in the ISO-PC (Rittmann 1995) computer code were used for shielding calculations.

\section{5:4 NORMAL TRANSPORT CONDITIONS}

\subsubsection{Conditions To Be Evaluated}

Gamma dose rates were evaluated at the surface of the cask (with an offset of $1.0 \mathrm{~cm}$ ) and at $2.0 \mathrm{~m}(6.6 \mathrm{ft})$ from the cask surface. Neutron dose rates were estimated at the surface of the cask.

\subsubsection{Acceptance Criteria}

Transportation safety specifies a maximum of $2 \mathrm{mSv} / \mathrm{h}(200 \mathrm{mrem} / \mathrm{h})$ on any surface of the cask, $0.1 \mathrm{mSv} / \mathrm{h}(10 \mathrm{mrem} / \mathrm{h})$ at $2.0 \mathrm{~m}(6.6 \mathrm{ft})$ from the cask surface, and $0.02 \mathrm{mSv} / \mathrm{h}(2 \mathrm{mrem} / \mathrm{h})$ in any normally occupied space. If these limits are exceeded, material will be removed from the cask.

\subsubsection{Assumptions}

The following assumptions were made and applied to the shielding model.

1. The steel in the closure mechanism tube was combined with the steel covering the outside of the mechanism to make a single inner shell and outer shell.

2. The air space in the closure mechanism was added to the distance to the detector.

3. The cask end opposite the closure contains a steel plunger mechanism that extends through the shielding (see drawing H-3-13699 [Part A, Section 10.11). A cylindrical source with a diameter equivalent to the plunger mechanism and a length equivalent to the cask cavity was used to determine the dose outside the plunger. This dose was 
added to the dose considered at the cask end, assuming a uniform steel and lead plug without the plunger. It is assumed that the cask is transported with the sample boat in place and that a steel rod fills the hole through the plunger mechanism.

4. The contents were assumed to be mainly iron pieces with a nominal density of $2.0 \mathrm{~g} / \mathrm{cm}^{3}$. This density was arrived at by considering that the cask is filled with uniformly distributed iron pieces with a density approximately one-fourth of the nominal iron density of $7.86 \mathrm{~g} / \mathrm{cm}^{3}$. Note that dose rates are more sensitive to material density than material type; therefore, this is a conservative approach that reduces the effects of self-shielding in the payload.

5. The mixed activation products were conservatively assumed to be all ${ }^{60} \mathrm{Co}$.

6. The mixed fission products were conservatively assumed to be all ${ }^{137} \mathrm{Cs}$.

7. Bremsstrahlung was only considered for isotopes evaluated; e.g., ${ }^{137} \mathrm{Cs}$, and not for any other isotopes that may be present, such as ${ }^{90} \mathrm{Sr}$.

\subsubsection{Shielding Model}

The shielding source term considered is shown in Tables B5-1 and B5-2. The source parameters are shown in Table B5-3, and the shielding parameters are shown in Table B5-4. The data for the shielding and source parameters were taken from drawing $\mathrm{H}-3-13699$.

Table B5-3. Source Parameters.

\begin{tabular}{|c|c|c|c|c|c|}
\hline \multirow{2}{*}{ Source } & \multicolumn{2}{|c|}{ Diameter } & \multicolumn{2}{|c|}{ Length } & \multirow{2}{*}{$\begin{array}{l}\text { Volume } \\
\left(\mathrm{cm}^{3}\right)\end{array}$} \\
\hline & $\mathrm{cm}$ & in. & $\mathrm{cm}$ & in. & \\
\hline Overall (entire cask interior volume) & 7.938 & 3.125 & 62.2 & 24.49 & 3082.300 \\
\hline $\begin{array}{l}\text { Piunger only (part of source directly } \\
\text { below plunger area) }\end{array}$ & 3.334 & 1.3125 & 62.2 & 24.49 & 543.718 \\
\hline
\end{tabular}

Table B5-4. Shielding Parameters.

\begin{tabular}{|c|c|c|c|c|c|c|c|c|}
\hline \multirow[t]{2}{*}{$\begin{array}{l}\text { Detector } \\
\text { location }\end{array}$} & \multicolumn{2}{|c|}{$\begin{array}{l}\text { Steel inner wall } \\
\text { thickness }\end{array}$} & \multicolumn{2}{|c|}{ Lead thickness } & \multicolumn{2}{|c|}{$\begin{array}{l}\text { Steel outer wall } \\
\text { thickness }\end{array}$} & \multicolumn{2}{|c|}{$\begin{array}{l}\text { Distance to surface } \\
\text { detector (Including } \\
\text { source thickness) }\end{array}$} \\
\hline & $\mathrm{cm}$ & in: & $\mathrm{cm}$ & in. & $\mathrm{cm}$ & in. & $\mathrm{cm}$ & in. \\
\hline Side & 0.318 & 0.125 & 12.860 & 5.063 & 0.635 & 0.250 & 17.781 & 7.001 \\
\hline Closure end & 0.953 & 0.375 & 10.133 & 3.989 & 0.953 & 0.375 & 83.796 & 32.990 \\
\hline Plunger end & 1.905 & 0.750 & 12.065 & 4.750 & 0.953 & 0.375 & 77.127 & 30.365 \\
\hline \multirow{3}{*}{ Plunger } & \multicolumn{2}{|c|}{ Diameter } & \multicolumn{2}{|c|}{ Length } & & & & \\
\hline & $\mathrm{cm}$ & in. & $\mathrm{cm}$ & in. & & & & \\
\hline & 3.334 & 1.3125 & 14.923 & 5.875 & & & & \\
\hline
\end{tabular}


The ISO-PC program (Rittmann 1995) was used for the gamma-ray dose rate calculations. ISO-PC uses the point-kernel integration method to compute the dose rate at a detector location. Bremsstrahiung photons are accounted for in the dose rate calculations. Fluence-to-dose conversion factors were based on an anterior-to-posterior irradiation pattern (ANS 1991).

The neutron dose rate was determined using a method discussed in Estimation of Neutron Dose Rates from Nuclear Waste Packages (Nelson 1996). This is a very conservative method that does not take shielding or moderation into account.

\subsubsection{Shielding Calculations}

Table B5-5 shows the gamma dose, rate estimates calculated by ISO-PC for the mixed material inventory. The neutron dose rate calculations utilized data for $\alpha, n$ and spontaneous fission neutron production rates generated by ORIGEN. The neutron production rate information was then used in the dose rate calculation method described in Estimation of Neutron Dose Rates from Nuclear Waste Packages (Nelson 1996). The neutron dose rate was determined to be $0.0125 \mathrm{mSv} / \mathrm{h}(1.25 \mathrm{mrem} / \mathrm{h})$ at the cask surface. The neutron dose rate falls of by a factor of $1 / \mathrm{r}^{2}$ and is negligible at $2.0 \mathrm{~m}(6.6 \mathrm{ft})$. The ISO-PC input file, the ORIGEN input file, and the neutron dose calculations are attached in Part $B$, Section 5.8 .

Table B5-5. Maximum Dose Rates Around the Plutonium Recycle Test Reactor Graphite Cask.

\begin{tabular}{|c|c|c|c|c|}
\hline \multirow{3}{*}{ Detector orientation } & \multicolumn{4}{|c|}{ Detector location } \\
\hline & \multicolumn{2}{|c|}{ Surface $(1 \mathrm{~cm}$ offset$)$} & \multicolumn{2}{|c|}{$2 \mathrm{~m}$} \\
\hline & $\mathrm{mSv} / \mathrm{h}$ & $\mathrm{mrem} / \mathrm{h}$ & $\mathrm{mSv} / \mathrm{h}$ & mrem $/ \mathrm{h}$ \\
\hline Side (gamma and neutron) & 1.09 & 108.65 & $3.20 \mathrm{E}-03$ & 0.32 \\
\hline Closure end (gamma only) & 1.87 & 187.00 & $3.20 \mathrm{E}-03$ & 0.32 \\
\hline Plunger end plus plunger (gamma only) & 1.94 & 194.21 & $1.79 \mathrm{E}-\mathrm{O} 2$ & 1.79 \\
\hline Criteria. & 2.00 & 200.00 & $1.00 \mathrm{E}-01$ & 10.00 \\
\hline
\end{tabular}

\subsection{ACCIDENT CONDITIONS}

\subsubsection{Conditions To Be Evaluated}

A handling accident in which the source material was concentrated against the plunger end of the cask was considered.

\subsubsection{Acceptance Criteria}

The maximum dose rate at $1.0 \mathrm{~m}(3.3 \mathrm{ft})$ shall be less than $10 \mathrm{mSv} / \mathrm{h}(1,000 \mathrm{mrem} / \mathrm{h})$. 


\subsubsection{Assumptions}

The same assumptions as shown in Part B, Section 5.4.3, shall be used except that the source material will be concentrated in a cylinder that is the same diameter as the cask interior and $5.08 \mathrm{~cm}$ $\left(2.0 \mathrm{in}\right.$.) tall. The material density will be conservatively maintained as $2.0 \mathrm{~g} / \mathrm{cm}^{3}$.

\subsubsection{Shielding Model}

The shielding model shall be the same as used in Part B, Section 5.4.4, except that the source length will $5.08 \mathrm{~cm}(2.0 \mathrm{in}$.).

\subsubsection{Shielding Calculations}

Table B5-6 shows the gamma dose rate estimates for accident conditions as calculated by ISO-PC (Rittmann 1995). The neutron dose rate was not calculated as it is was already shown to be insignificant when compared to the gamma dose rate, even without shielding, in Part B, Section 5.4. The ISO-PC input file is attached in Part B, Section 5.8.

Table B5-6. Maximum Dose Rates Around the Plutonium Recycle Test Reactor Graphite Cask for Accident Conditions.

\begin{tabular}{|l|c|c|}
\hline \multirow{2}{*}{\multicolumn{2}{|c|}{ Detector orientation }} & \multicolumn{2}{|c|}{ Detector location (1 m) } \\
\cline { 2 - 3 } & $\mathrm{mSv} / \mathrm{h}$ & $\mathrm{mrem} / \mathrm{h}$ \\
\hline Side & $1.11 \mathrm{E}-02$ & 1.11 \\
\hline Closure end & $2.50 \mathrm{E}-02$ & 2.50 \\
\hline Plunger end plus plunger & $3.62 \mathrm{E}-01$ & 36.17 \\
\hline
\end{tabular}

\subsection{CONCLUSIONS}

The gamma dose rates shown in Table B5-5 for the mixed materials inventory are within the NTC acceptance criteria for a surface dose rate of less than $2 \mathrm{mSv} / \mathrm{h}(200 \mathrm{mrem} / \mathrm{h}), 0.1 \mathrm{mSv} / \mathrm{h}$ $(10 \mathrm{mrem} / \mathrm{h})$ at $2.0 \mathrm{~m}(6.6 \mathrm{ft})$, and $0.02 \mathrm{mSv} / \mathrm{h}(2 \mathrm{mrem} / \mathrm{h})$ at the driver's position, assuming the driver is no closer to the cask than $2.5 \mathrm{~m}$. As shown in Table B5-6, the maximum allowed accident condition dose rate is also met for the conditions evaluated. The neutron dose rate of $0.0125 \mathrm{mSv} / \mathrm{h}$ $(1.25 \mathrm{mrem} / \mathrm{h})$ at the cask surface is inconsequential for the material inventory considered as it falls off by a factor of $1 / r^{2}$ and is negligible in comparison to the gamma dose rate.

It should be noted that the shielding model is very conservative, assuming a contents density of $2.0 \mathrm{~g} / \mathrm{cm}^{3}$ that is evenly distributed in the cask volume and assuming that the activated materials inventory is all ${ }^{60} \mathrm{Co}$. During use, the dose rates are measured prior to shipment in accordance with facility procedures. Particular attention must be paid to the plunger end of the cask due to the reduced shielding in this area. If the dose rate on any surface exceeds the NTC requirements, payload material will be removed in order to meet the dose rate limits. 


\subsection{REFERENCES}

ANS, 1991, Neutron and Gamma-Ray Fluence-to-Dose Factors, ANSI/ANS-6.1.1-1991, American Nuclear Society, La Grange Park, Illinois.

Nelson, J. V., 1996, Estimation of Neutron Dose Rates from Nuclear Wasțe Packages, (internal memo 8M730-JVN-96-007 to J. R. Green, March 8), Westinghouse Hanford Company, Richland, Washington.

Rittmann, P. D., 1995, ISO-PC Version 1.98 - User's Guide, WHC-SD-WM-UM-030, Rev. 0, Westinghouse Hanford Company, Richland, Washington.

Schmittroth, F. A., 1994, Conversion of ORIGEN2 to Sun Workstations, WHC-SD-NR-SWD-00, Rev. 1 , Westinghouse Hanford Company, Richland, Washington.

\subsection{APPENDICES}

\subsubsection{ISO-PC Input Files}

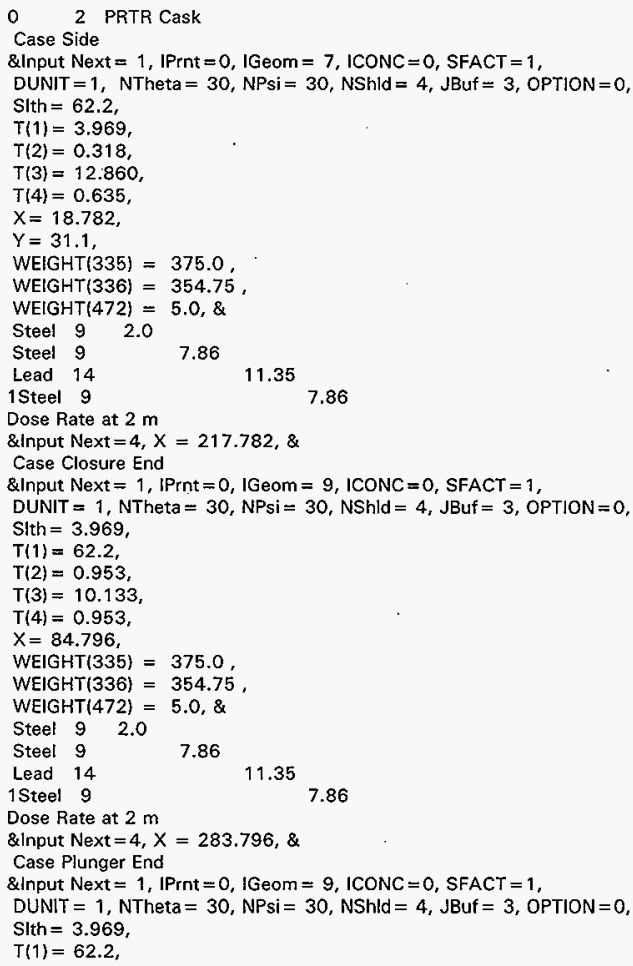




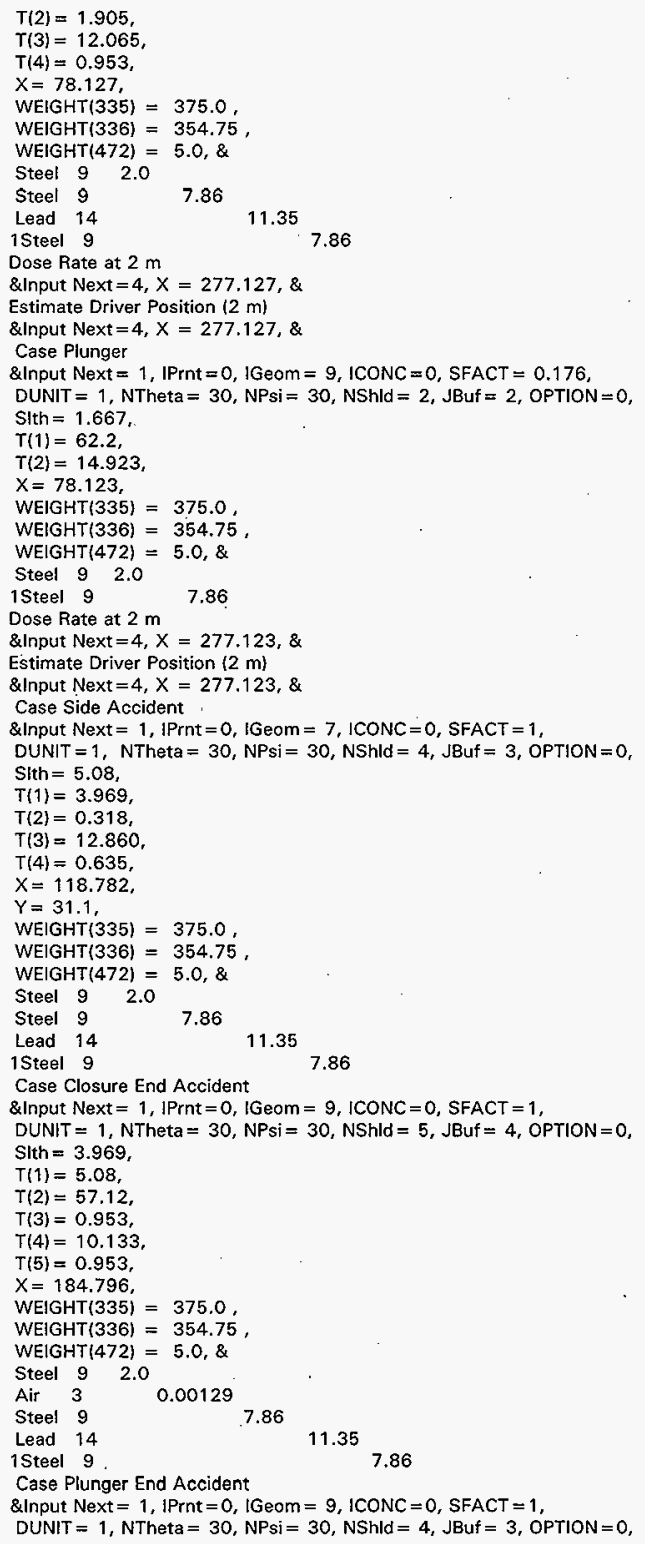




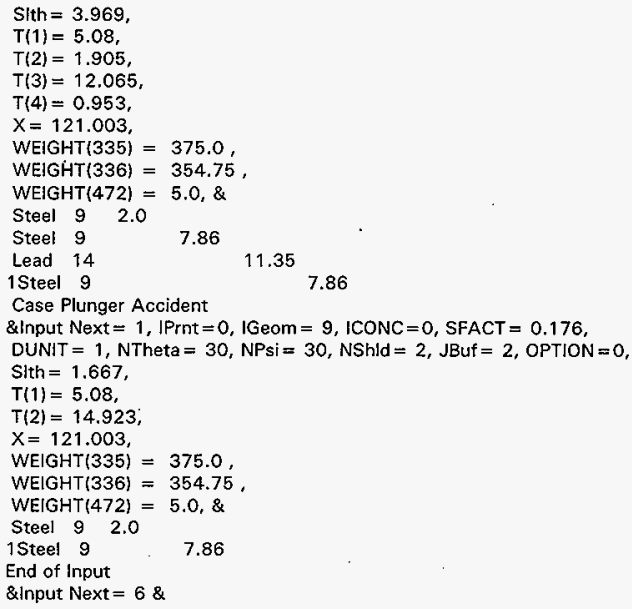

\subsubsection{ORIGEN Input File}

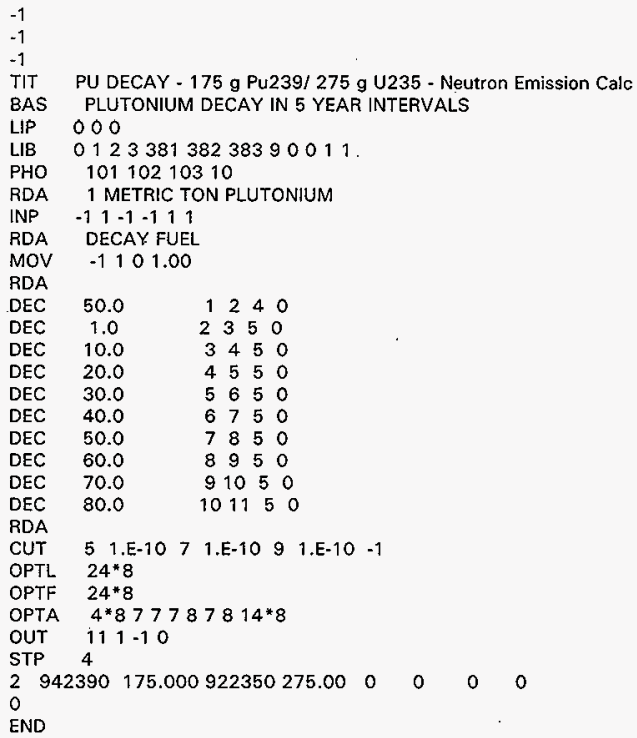




\subsubsection{Neutron Dose Calculations}

The neutron dose rate was determined using the method described in Estimation of Neutron Dose Rates from Nuclear Waste Packages (Nelson 1996). In this method, the total neutron source term $S(T)$, which accounts for neutron multiplication, is determined by adding the spontaneous fission source term (S(SF)) and the $\alpha, n$ source term $(S(\alpha, n))$ and dividing by 1 minus the $k_{\text {eff }}$.

$$
S(S T)=\frac{(S(S F)-S(\alpha, n))}{\left(1-k_{\text {eff }}\right)}
$$

$\mathrm{S}(\mathrm{SF})$ and $\mathrm{S}(\alpha, \mathrm{n})$ are determined either from Nelson (1996) or ORIGEN (see Part B, Section 5.8.2). After $\mathrm{S}(\mathrm{ST})$ is determined, it is used to determine the dose rate in the equation;

$$
D(r)=\frac{0.01 \cdot S(S T)}{r^{2}}
$$

where $r$ is the distance from the source and $D(r)$ is the dose in $m r e m / h$ as a function of $r$.

Therefore, the neutron dose for the PRTR Graphite Cask is estimated as follows. Using S(SF) and $S(\alpha, n)$ from ORIGEN and conservatively assuming a $k_{\text {eff }}$ of 0.8 (Part B, Section 6.0), $S(S T)$ is determined to be,

$$
S(S T)=\frac{3.967+7.927 \times 10^{3}}{(1-0.8)}=3.965 \times 10^{4} \mathrm{n} / \mathrm{s} .
$$

Assuming $r$ to be $17.78 \mathrm{~cm}$ (the approximate surface of cask as measured radially), the total neutron dose rate is estimated to be,

$$
D(r)=\frac{0.01 \cdot 3.965 \times 10^{4}}{17.78^{2}}=1.25 \mathrm{mrem} / \mathrm{h}
$$


HNF-SD-TP-SEP-063, Rev. 0

5.8.4 Peer Review Checklist for Shielding

\section{CHECKLIST FOR TECHNICAL PEER REVIEH}

Document: Safety Evaluation for Packaging (Onsite) PRTR Cask, June 4, 1997, by John McCoy.

Scope: Shielding portion of the analysis.

Yes No NA

[ ] [ ] [X]

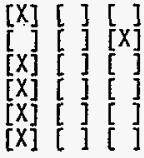

Previous reviews complete and cover analysis, up to scope of this review, with no gaps.

Problem completely defined.

Accident scenarios developed in a clear and logical manner. Necessary assumptions explicitly stated and supported.

Computer codes and data files documented.

Data used in calculations explicitly stated in document.

Data checked for consistency with original source information as applicable.

[X] [ ] [ ] Mathematical derivations checked including dimensional consistency of results.

[X] [ ] [ ] Models appropriate and used within range of validity or use outside range of established validity justified.

[X] [ ] [ ] Hand ca]culations checked for errors. Spreadsheet results should be treated exactly the same as hand calculations.

[X] [ ] [ ] Software input correct and consistent with document reviewed.

$[X][][] \quad$ Software output consistent with input and with results reported in document reviewed.

[X] [ ] [ ] Limits/criteria/guidelines applied to analysis results are appropriate and referenced. Limits/criteria/guidelines checked against references.

[X] [ ] [ ] Safety margins consistent with good engineering practices.

$[X][][]$ Conclusions consistent with analytical results and applicable imits.

[X] [ ] [ ] Results and conclusions address all points required in the problem statement.

[X] [ ] [ ] Format consistent with appropriate NRC Regulatory Guide or other standards

[ ] [X] Review calculations, comments, and/or notes are attached.

[X] [ ] [ ] Document approved.

Anthony Savino AWSon. 6/ 4/97 Reviewer (Printed Name and Signature) 


\subsection{CRITICALITY EVALUATION}

The criticality analysis of the PRTR Graphite Cask was completed in Limits for Fissionable Material in Small Bore Transfer Casks and Lead Pigs (see Section 6.1). This analysis demonstrates that the PRTR Graphite Cask remains subcritical when loaded with $275 \mathrm{~g}$ or less of ${ }^{235} \mathrm{U}$. The package is also subcritical when loaded with $175 \mathrm{~g}$ or less of ${ }^{239} \mathrm{Pu},{ }^{233} \mathrm{U},{ }^{237} \mathrm{~Np},{ }^{241} \mathrm{Am},{ }^{243} \mathrm{Am},{ }^{244} \mathrm{Cm}$, and ${ }^{247} \mathrm{Cm}$. The following fissionable materials were not analyzed and cannot be shipped in excess of safeguards accountability limits: ${ }^{242 \mathrm{~m}} \mathrm{Am},{ }^{243} \mathrm{Cm},{ }^{245} \mathrm{Cm},{ }^{249} \mathrm{Cf}$, or ${ }^{251} \mathrm{Cf}$.

\subsection{APPENDIX: CRITICALITY SAFETY ANALYSIS}


Project No.

Internal Distribution

VC Asmund

AL Doherty

DL Haggard

AW Prichard

RD Scheele

Library

Record Copy

File/LB

Subject NCS Basis Memo 96-2. Limits for Fissionable Material in Small Bore Transfer Casks and Lead Pigs

Reference 1: $\quad$ PNL Laboratory Safety, "Criticality Safety," PNL-MA-25, January 1994.

Reference 2: Oak Ridge National Laboratory, SCALE 4.2 Modular Code System for Performing Standardized Computer Analvses for Licensing Evaluation, v1 -3, CCC-545, November 1993.

Reference 3: $\quad$ SL Larson, "A Systematic Approach to Establishing Criticality Biases," Proceedings of the International Conference on Nuclear Criticality 1995, Albuquerque, NM, September $17-21,1995$.

Reference 4: LE Hansen, ED Clayton, RC Lloyd, SR Bierman and RD Johnson, "Critical Parameters of Plutonium Solutions," Parts I and II, Nuclear Applications, 6 371-390, 1969.

Reference 5: BM Durst, SR Bierman and ED Clayton, "Handbook of Critical Experiments Benchmarks," PNL-2700, March 1978.

Reference 6: - RC Lloyd, CR Richey, ED Clayton, and DR Skeen, "Criticality Studies with Plutonium Solutions," Nuclear Science and Engineering, vol 25, pp 165-173, 1966.

Reference 7: NEA Nuclear Science Committee, Intemmational Handbook of Evaluated Criticality Safetv Benchmark Experiments, Experiment HEU-MET-FAST-004, NEA/MSC/DOC(95)03/II, 1995.

Reference 8: $\quad$ SR Bierman, BM Durst and ED Clayton, "Critical Experiments with Subcritical Clusters of $2.35 \mathrm{wt} \%$ and $4.31 \mathrm{wt} \%{ }^{235} \mathrm{U}$ Enriched $\mathrm{UO}_{2}$ Rods in Water with Uranium or Lead Reflecting Walls," NUREG/CR-0796, vol 2, 1979.

This basis memo establishes the nuclear criticality safety limits for the loading, unloading, storage and on-site transportation of fissionable material in the following casks: the Large Bore Cask, the Long Bore Cask, the PRTR Graphite Cask and the One Ton Cask and any other lead shielded cask with a maximum inner volume of 5 liters. This memo validates the limits against the requirements of DOE Orcer 5480.24 issued 8/12/92 and ANSI/ANS-8.1-1983 [Reaffirmed 1988]. 
HNF-SD-TP-SEP-063, Rev. 0

NCS Basis Memo 96-2

December 30, 1996

Page 2

\section{Review of Methods Used Previously}

The mass limits for water reflected fissionable material were previously used for the transfer casks. The casks were not specifically analyzed previously. However, calculations have shown that the lead used for shielding may be a better reflector than water thereby possibly reducing the minimum critical mass.

\section{Validation of the Technical Bases per ANSI/ANS-8.1-1983 [1988] Requirements}

An analysis was conducted per the requirements of ANSL/ANS-8.1-1983 [Reaffirmed 1988]. The results are as follows:

(1) Describe the method with sufficient detail, clarity, and lack of ambiguity to allow independent duplication of results.

The transfer casks analyzed in this memo have a small inner bore which limits the contents. Because a large number of fuel pins can not fit into the casks, a mass limit but not a pin limit was determined for the casks. Fuel pins and pieces can be transported and stored in the casks under the mass limit.

\section{(1.1) Optimum Concentration Determination}

The first step in analyzing the lead shielded casks was to determine the optimum concentration of an aqueous spherical solution of fissile material with a tight fitting spherical lead reflector. The mass of material modeled is equal to a double batch under the current water reflected limits for these materials. A lead reflector thickness of 8 " was chosen because the casks have a comparable lead thickness. The results as given in Table 1 indicate that the optimum fissile concentrations with lead reflection are $32 \mathrm{~g} / \mathrm{l}$ for ${ }^{239} \mathrm{Pu}$ and $55 \mathrm{~g} / \mathrm{l}$ for ${ }^{235} \mathrm{U}$. These values are comparable to the optimum water reflected concentrations found in previous work. A $\mathrm{K}_{95 / 95}$ value was not calculated as these calculations are for comparison only. However, notice the systems are supercritical with a lead reflector although the mass is less than the minimum critical water reflected mass $\left(530 \mathrm{~g}^{259} \mathrm{Pu}\right.$ or $\left.738 \mathrm{~g}^{235} \mathrm{U}\right)$. This point indicates that lead is a significantly better reflector than water for an aqueous solution system of ${ }^{239} \mathrm{Pu}$ or ${ }^{235} \mathrm{U}$.
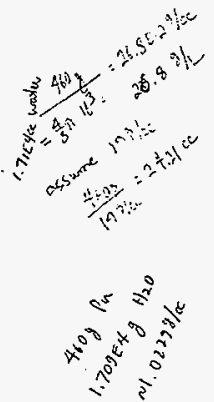

\begin{tabular}{|c|c|c|c|}
\hline Case $^{2}$ & Fissile density $(\mathrm{g} / \mathrm{l})$ & KENO $k_{\text {eftective }}$ & KENO Uncertainty \\
\hline \multicolumn{4}{|c|}{${ }^{19} \mathrm{P}$ u Scrap } \\
\hline $460 \mathrm{~g}$ sphere & 27 & $1.0522 \mathrm{I}_{\mathrm{A}}$ & 0.00114 \\
\hline $460 \mathrm{~g}$ sphere & 32 & $1.05610^{\circ, .2^{20-7}}$ & $0.001130 .2^{2}=276$ \\
\hline $460 \mathrm{~g}$ sphere & 37 & 1.05152 & 0.00113 \\
\hline $460 \mathrm{~g}$ sphere & 42 & 1.04596 & 0.00150 \\
\hline
\end{tabular}

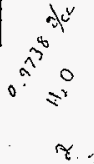


NCS Basis Memo 96-2

December 30, 1996

Page 3

\begin{tabular}{|c|c|c|c|}
\hline Case $^{i}$ & Fissile density $(\mathrm{g} / \mathrm{l})$ & KENO $k_{\text {effective }}$ & KENO Uncertainty \\
\hline \multicolumn{4}{|c|}{${ }^{235} U S c r a p$} \\
\hline $738 \mathrm{~g}$ sphere & 45 & 1.04042 & 0.00123 \\
\hline $738 \mathrm{~g}$ sphere & 50 & 1.04452 & 0.00116 \\
\hline $738 \mathrm{~g} \mathrm{sphere}$ & 55 & 1.04661 & 0.00120 \\
\hline $738 \mathrm{~g}$ sphere & 60 & 1.04492 & 0.00123 \\
\hline
\end{tabular}

\section{(1.2) Large Bore, Long Bore, PRTR Graphite and One Ton Sample Cask Analyses}

The four casks specifically analyzed were the Large Bore, the Long Bore, the PRTR Graphite and the One Ton Sample Casks. The casks were modeled using the KENO-Va code to ensure subcriticality of the water reflected mass limit for ${ }^{235} \mathrm{U}$ and ${ }^{239} \mathrm{Pu}$ in the cylindrical geometry of the casks during normal operations and in the event of a single loss of contingency. The inner diameter of the cask was increased in the KENO model by $0.4^{\prime \prime}$ to allow for tolerance and create a more optimum concentration of material in the cask. The interior length of the cask was modeled as 1" longer than the actual length for the same reasons. Iead has a large thermal scattering cross section and small thermal absorption cross section. Therefore, the lead thickness of the cask was also increased in the model to allow for tolerance as a thicker lead reflector is more reactive for thermal, optimally moderated system. The actual dimensions and the as modeled dimensions for each of the four casks modeled are given in Table 2.

\begin{tabular}{||l||c|c|c|c|c|c||}
\hline \multicolumn{7}{|c|}{ Table 2 Cask Dimensions } \\
\hline \multicolumn{1}{|c|}{ Nominal Dimensions } & \multicolumn{3}{|c|}{ Modeled Dimensions } \\
\hline Cask & $\begin{array}{c}\text { Inner } \\
\text { Diameter }\end{array}$ & $\begin{array}{c}\text { Inner } \\
\text { Length }\end{array}$ & $\begin{array}{c}\text { Lead } \\
\text { Thickness }\end{array}$ & $\begin{array}{c}\text { Inner } \\
\text { Diameter }\end{array}$ & $\begin{array}{c}\text { Inner } \\
\text { Length }\end{array}$ & $\begin{array}{c}\text { Lead } \\
\text { Thickness }\end{array}$ \\
\hline Large Bore & $4^{\prime \prime}$ & $26^{\prime \prime}$ & $7.75^{\prime \prime}$ & $4.4^{\prime \prime}$ & $27^{\prime \prime}$ & $8.34^{\prime \prime}$ \\
\hline Long Bore & $3^{\prime \prime}$ & $39^{\prime \prime}$ & $7.5^{\prime \prime}$ & $3.4^{\prime \prime}$ & $40^{\prime \prime}$ & $8.09^{\prime \prime}$ \\
\hline PRTR Graphite & $3.25^{\prime \prime}$ & $25^{\prime \prime}$ & $5.375^{\prime \prime}$ & $3.6^{\prime \prime}$ & $26^{\prime \prime}$ & $5.96^{\prime \prime}$ \\
\hline One Ton Sample & $3^{\prime \prime}$ & $13.125^{\prime \prime}$ & $6.5^{\prime \prime}$ & $3.4^{\prime \prime}$ & $14.25^{\prime \prime}$ & $7.09^{\prime \prime}$ \\
\hline
\end{tabular}


NCS Basis Memo 96-2

December 30, 1996

Page 4

The casks were modeled with the fissionable material in a homogeneous water solution filling the bore. Full water reflection $(\geq 12$ ") was included around the lead shielding to model the most reactive reflection scenario possible. Three cases with different fissile masses and concentrations were modeled. The first case demonstrates subcriticality in the event the mass limit is exceeded while the latter two cases demonstrate that normal operations will have a reactivity less than the normal operations limit of 0.95 . In the first case, the minimum critical mass of material, $820 \mathrm{~g}$ ${ }^{235} \mathrm{U}$ or $530 \mathrm{~g}^{239} \mathrm{Pu}$, was modeled with the concentration of the material determined by the volume of the cask. In the second case, the cask was filled with the water reflected mass limit of material, $369 \mathrm{~g}^{235} \mathrm{U}$ or $230 \mathrm{~g}^{239} \mathrm{Pu}$, with the concentration again determined by the volume of the cask. The final case modeled the material at the optimum concentration, $55 \mathrm{~g} / 1$ for ${ }^{235} \mathrm{U}$ or $32 \mathrm{~g} / 1$ for ${ }^{239} \mathrm{Pu}$, with the mass of material determined by the volume of the cask. As shown in Table 3 , each case was subcritical. Note the reactivity is too low in these cases to accurately determine a $\mathrm{K}_{\text {gs/gs }}$ value. Because the statistical analysis of the code was performed on critical benchmarks, extrapolation to these low reactivities is not possible. However, these low reactivities indicate the systems are very subcritical with a $\mathrm{k}_{\text {effective }}$ certainly less than 0.90 .

\begin{tabular}{|c|c|c|c|c|c|}
\hline Cask & $\mid$\begin{tabular}{c|} 
Max Cask \\
Diameter (in)
\end{tabular} & $\begin{array}{c}\text { Fissile } \\
\text { densitv (g/l) }\end{array}$ & $\begin{array}{c}\text { Fissile mass } \\
(\mathrm{g})\end{array}$ & $\begin{array}{l}\text { Keno } \\
\text { k.monte }\end{array}$ & $\begin{array}{c}\text { Keno } \\
\text { Uncertainty }\end{array}$ \\
\hline \multicolumn{6}{|c|}{${ }^{235} U \dot{S}$ crap } \\
\hline \multirow[t]{2}{*}{ Large Bore } & $4: 4$ & 122.2 & 820 & 0.78525 & 0.00137 \\
\hline & 4.4 & 55 & 369 & 0.64529 & 0.00112 \\
\hline \multirow{3}{*}{ Long Bore } & 3.4 & 138.3 & 820 & 0.61548 & 0.00105 \\
\hline & 3.4 & 62.3 & 369 & 0.49988 & 0.00104 \\
\hline & 3.4 & 55 & 326 & 0.47577 & 0.00100 \\
\hline \multirow[t]{3}{*}{ PRTR Graphite } & 3.6 & 184.6 & 820 & 0.66289 & 0.00127 \\
\hline & 3.6 & 83.1 & 369 & 0.56227 & 0.00108 \\
\hline & 3.6 & 55 & 244 & 0.49308 & 0.00098 \\
\hline \multirow[t]{2}{*}{ One Ton Sample } & 3.4 & 391.7 & 820 & 0.60800 & 0.00122 \\
\hline & 3.4 & 176.3 & 369 & 0.54668 & 0.00125 \\
\hline . & 3.4 & 55 & 115 & 0.39872 & 0.00094 \\
\hline \multicolumn{6}{|c|}{${ }^{239} P_{u}$ Scrap } \\
\hline \multirow[t]{3}{*}{ Large Bore } & 4.4 & 79 & 530 & 0.78995 & 0.00130 \\
\hline & 4.4 & 34.3 & 230 & 0.66425 & 0.00107 \\
\hline & 4.4 & 32 & 215 & 0.64965 & 0.00119 \\
\hline \multirow[t]{3}{*}{ Long Bore } & 3.4 & 89.4 & 530 & 0.62651 & 0.00117 \\
\hline & 3.4 & 38.8 & 230 & 0.51776 & 0.00094 \\
\hline & 3.4 & 32 & 190 & 0.48584 & 0.00088 \\
\hline
\end{tabular}


NCS Basis Memo 96-2

December 30, 1996

Page 5

\begin{tabular}{|c|c|c|c|c|c|}
\hline Cask & $\begin{array}{c}\text { Max Cask } \\
\text { Diameter (in) }\end{array}$ & $\begin{array}{c}\text { Fissile } \\
\text { densitv }(g / l)\end{array}$ & $\begin{array}{c}\text { Fissile mass } \\
(\mathrm{g})\end{array}$ & $\begin{array}{l}\text { Keno } \\
\text { k.manive }\end{array}$ & $\begin{array}{c}\text { Keno } \\
\text { Uncertainty } \\
\end{array}$ \\
\hline \multirow[t]{3}{*}{ PRTR Graphite } & 3.6 & 119.4 & 530 & 0.66219 & 0.00130 \\
\hline & 3.6 & 51.8 & 230 & 0.57143 & 0.00114 \\
\hline & 3.6 & 32 & 142 & 0.49819 & 0.00082 \\
\hline \multirow[t]{3}{*}{ One Ton Sample } & 3.4 & 253.2 & 530 & 0.59768 & 0.00121 \\
\hline & 3.4 & 110 & 230 & 0.54649 & 0.00113 \\
\hline & 3.4 & 32 & 67 & 0.40650 & 0.00093 \\
\hline \multicolumn{6}{|c|}{ Benchmark Statistics } \\
\hline \multicolumn{6}{|c|}{ Bias $=0.00032$} \\
\hline \multicolumn{6}{|c|}{ Standard Deviation $=0.01163$} \\
\hline \multicolumn{6}{|c|}{ Variance $=0.00014$} \\
\hline
\end{tabular}

The lead thickness of the Large Bore Cask containing $230 \mathrm{~g}$ of ${ }^{239} \mathrm{Pu}$, the most reactive case at the mass limit as given in Table 3, was increased by $4^{\prime \prime}$ to $28^{\prime \prime}$ to model a loss of reflection limit accident. This scenario could occur if lead bricks were stacked around the cask or two casks were placed side by side. As determined in Section 1.3,28" of lead is considered critically infinite such that increasing the thickness would not increase reactivity. The $k_{\text {enicctive }}$ of the cask increased to $0.73001 \pm 0.00111$ which is clearly still subcritical.

Note the calculations shown here indicate the water reflected limits in use at the Laboratory are appropriate for these lead shielded casks. This fact does not, however, indicate that lead is a comparable reflector to water for thermal systems. In these cases, the geometry of the casks limits the mass and concentration such that optimum conditions can not be realized.

\section{(1.3) Five Liter Cask Analysis}

Instead of analyzing every small bore cask and lead transfer pig in use at the Laboratory, the maximum fissionable mass limit for a cask with an inner volume of $5 \mathrm{~L}$ and an infinite lead thickness was determined. The fissile material was modeled as a sphere surrounded by a tight fitting spherical lead reflector as this case is most reactive. A mass limit of $275 \mathrm{~g}^{235} \mathrm{U}$ or $175 \mathrm{~g}$ ${ }^{239} \mathrm{Pu}$ ensures the system will remain subcritical under all loss of contingency scenarios as given in Table 4. Note ${ }^{235} \mathrm{U}$ was not modeled with an increased volume as the normal condition results in an optimally moderated solution. 
HNF-SD-TP-SEP-063, Rev. 0

NCS Basis Memo 96-2

December 30, 1996

Page 6

\begin{tabular}{|c|c|c|c|c|c|c|c|}
\hline $\operatorname{Case}^{\circ}$ & $\begin{array}{c}\text { Cask } \\
\text { Volume (l) }\end{array}$ & $\begin{array}{c}\text { Fissile } \\
\text { density (g/) }\end{array}$ & Fissile mass & $\begin{array}{l}\text { Lead } \\
\text { Thickness } \\
\text { (in) }\end{array}$ & $\begin{array}{l}\text { KENO } \\
K_{\text {efiective }}\end{array}$ & $\begin{array}{l}\text { KENO } \\
\text { Uncertainty }\end{array}$ & Kassos \\
\hline \multicolumn{8}{|c|}{${ }^{239} \mathrm{Pu}$ Scrap } \\
\hline Normal Conditions & 5 & 35 & 175 & 28 & 0.84919 & 0.00100 & 0.873 \\
\hline Loss of Mass Limit & 5 & 70 & 350 & 28 & 0.93479 & 0.00108 & 0.986 \\
\hline Loss of Reflector Limit & 5 & 35 & 175 & 32 & 0.86916 & 0.00133 & 0.877 \\
\hline Loss of Volume Limit I & 7.47 & 32 & 175 & 28 & 0.88350 & 0.00108 & 0.880 \\
\hline \multicolumn{8}{|c|}{${ }^{235} U$ Scrap } \\
\hline Normal Conditions & 5 & 55 & 275 & 28 & 0.83077 & 0.00114 & 0.858 \\
\hline Loss of Mass Limit & 5 & 110 & 550 & 28 & 0.96002 & 0.00140 & 0.987 \\
\hline Loss of Reflector Limit & 5 & 55 & 275 & 32 & 0.83255 & 0.00117 & 0.859 \\
\hline \multicolumn{8}{|c|}{$\begin{array}{l}{ }^{\mathrm{b}} \text { Each case models a sphere of fissile material surrounded by a tight fitting spherical lead reflector of } \\
\text { the indicated thickness. Full water reflection is also modeled around the lead. }\end{array}$} \\
\hline \multicolumn{8}{|c|}{ Benchmark Statistics } \\
\hline \multicolumn{8}{|c|}{ Bias $=0.00032$} \\
\hline \multicolumn{8}{|c|}{ Standard Deviation $=0.01163$} \\
\hline \multicolumn{8}{|c|}{ Variance $=0.00014$} \\
\hline
\end{tabular}

Therefore the mass limit for the Large Bore, the Long Bore, the One Ton Sample Cask and the PRTR Graphite Cask as well as any lead shielded cask with a maximum inner volume of $5 \mathrm{~L}$ is set at $275 \mathrm{~g}^{235} \mathrm{U}$ or $175 \mathrm{~g}^{239} \mathrm{Pu}$ to provide consistency between the casks. The scrap limit found for ${ }^{239} \mathrm{Pu}$ is applicable to all other fissionable materials with a minimum critical mass greater than that of ${ }^{239} \mathrm{Pu}$ as given in Table 6.5 of Reference 1. Fissionable material more reactive than ${ }^{239} \mathrm{Pu}$, i.e. ${ }^{242 \mathrm{~m}} \mathrm{Am},{ }^{243} \mathrm{Cm},{ }^{245} \mathrm{Cm},{ }^{249} \mathrm{Cf}$, or ${ }^{251} \mathrm{Cf}$ have not been analyzed; however these materials are considered to be insignificant for the purposes of criticality safety provided the mass does not exceed the safeguards accountability limits. None of these restricted materials are currently accounted for at the Pacific Northwest National Laboratory; therefore violation of this limit is not credible. Sum of Fractions method (Ref. 1, Table 6.1) may be used to determine limit compliance for mixtures of fissionable material.

\section{(1.4) Spacing Requirements}

The minimum $12^{\prime \prime}$ edge-to-edge spacing requirement for batches of fissionable material is applicable to the transfer casks and lead pigs. Because the lead in the casks is not of an inifinite thickness for criticality, material around the cask will affect the reactivity of the cask. However, the cask was proven to be subcritical with an infinite lead thickness in all directions. Therefore, the 12" edge-to-edge spacing requirement is in effect between the cask and other batches of 
NCS Basis Memo 96-2

December 30, 1996

Page 7

fissionable material but no spacing requirements are needed between the cask and other reflectors.

(2) State computer programs used, the options, the recipes for choosing mesh points where applicable, the cross section sets, and any numerical parameters necessary to describe the input.

The SCAIE 4.2 system of codes $^{2}$ was used to model the casks. The codes were executed on either a HP 755 with HP-UNIX version 9.03 or a HP 735 running HP-UNIX version 9.05 . Code quality assurance documentation verifies the two operating systems give identical results. The NITAWL code was used to process cross-section data and KENO-Va was used to model the cask geometry and predict $k_{\text {effective. }}$ The standard 27 -group ENDF/B-IV cross-section library was used throughout. All calculations rar 120 generations with 5000 neutrons tracked per generation in $\mathrm{KENO}-\mathrm{Va}$. The first 20 generations were skipped when determining the standard deviation of the run. All input files containing geometry specification and material atom densities are included in Appendix A.

\section{(3) Identify experimental data and list parameters derived therefrom for use in the validation of the model.}

The results of the experimental benchmarks modeled with the SCALE 4.2 codes are shown in Table 5. These cases were chosen to represent the materials and geometries used in the cask calculations such that the code calculational scheme and cross section libraries are benchmarked. Therefore, ${ }^{239} \mathrm{Pu}$ solution and ${ }^{235} \mathrm{U}$ solution benchmarks are included in the set to represent the fissile solution and the lead wall benchmarks are included to represent the lead walls of the casks. The benchrnark results define the code statistics used in the determination of the $\mathrm{K}_{9 s / 95}$ value for each run. Each benchmark case tracked 5000 neutrons per KENO generation for 120 generations with 20 generations skipped. The same scheme was employed in generating crosssections sets and calculating $k_{\text {enective }}$ as was used to model the worst case geometries. All parameters required to model these benchmarks are described in the input files given in Appendix B and the references indicated in Table 5. 
NCS Basis Memo 96-2

December 30, 1996

Page 8

\begin{tabular}{|c|c|c|c|}
\hline Description & Reference & KENO K_mentin & KENO Uncertainty \\
\hline \multicolumn{4}{|l|}{ PuNO, Spheres with Spherical Reflectors. } \\
\hline $24.4 \mathrm{~g} \mathrm{Pu} / 1$ sphere with full water reflection & 4 & 1.01407 & 0.00111 \\
\hline $26.3 \mathrm{~g} \mathrm{Pu} / \mathrm{l}$ with thin steel shell + full water & 5 & 1.01064 & 0.00112 \\
\hline $34.3 \mathrm{~g} \mathrm{Pu} / 1$ with thin steel shell & 5 & 0.99318 & 0.00127 \\
\hline $35.5 \mathrm{~g} \mathrm{Pu} / 1$ with $4 "$ concrete shell & 5 & 1.02249 & 0.00105 \\
\hline $32.8 \mathrm{~g} \mathrm{Pu} / \mathrm{l}$ with $4^{\prime \prime}$ concrete shell & 6 & 1.02516 & 0.00115 \\
\hline $29.6 \mathrm{~g}$ Pu/l with $10^{\prime \prime}$ concrete shell & 6 & 1.01282 & 0.00101 \\
\hline \multicolumn{4}{|c|}{ Cencrete Reflected Arravs of 93.2 wt\% Enriched Uranul Nitrate } \\
\hline $4 \times 4$ Array with $67.28 \mathrm{gU} / 1$ Solution & 7 & 1.01074 & 0.00112 \\
\hline $2 \times 2$ Array with $76.09 \mathrm{gU} / 1$ Solution & 7 & 1.00676 & 0.00116 \\
\hline $4 \times 4$ Array with $360.37 \mathrm{gU} / 1$ Solution & 7 & 1.01108 & 0.00132 \\
\hline \multicolumn{4}{|c|}{ 431 wt\% Enriched Optimum Moderated UO, Pins } \\
\hline Square array with lead wall at $0^{\prime \prime}$ & 1. 8 & 1.00195 & 0.00103 \\
\hline Square array with lead wall at $0.26 "$ & 8 & 1.00430 & 0.00113 \\
\hline Square array with lead wall at $0.77^{\prime \prime}$ & 8 & 1.00043 & 0.00111 \\
\hline Square array with lead wall at $2.13^{\prime \prime}$ & 8 & 0.98598 & 0.00104 \\
\hline Square array without lead wall & 8 & 0.98120 & 0.00101 \\
\hline \multicolumn{4}{|l|}{ 4.31 wt\% Enriched Undermoderated UO. Pins } \\
\hline Square array with lead wall at $0^{\prime \prime}$ & 8 & 1.00225 & 0.00105 \\
\hline Square array with lead wall at $0.26^{\prime \prime}$ & 8 & 1.00165 & 0.00098 \\
\hline Square array with lead wall at $0.77^{\prime \prime}$ & 8 & 0.99710 & 0.00106 \\
\hline Square array with lead wall at $2.13^{\prime \prime}$ & 8 & $0 . \dot{99544}$ & 0.00111 \\
\hline Square array without lead wall & 8 & 0.99568 & 0.00105 \\
\hline \multicolumn{4}{|c|}{2.35 w: $\%$ Enriched Optimum Moderated UO, Pins } \\
\hline Square amay with lead wall at $0^{\prime \prime}$ & 8 & 0.99550 & 0.00083 \\
\hline Square array with lead wall at $0.26^{\prime \prime}$ & 8 & 0.99414 & 0.00096 \\
\hline Square anray with lead wall at $1.29^{\prime \prime}$ & 8 & 0.99176 & 0.00084 \\
\hline
\end{tabular}


NCS Basis Memo 96-2

December 30, 1996

Page 9

\begin{tabular}{|c|c|c|c|}
\hline Description & Reference $\mathrm{i}$ & KENOK_manter & KENO Uncertainty \\
\hline Square array without lead wall & 8 & 0.98542 & 0.00086 \\
\hline \multicolumn{4}{|c|}{2.35 wt\% Enriched Undermoderated UO, Pins } \\
\hline Square array with lead wall at $0^{\prime \prime}$ & 8 & 0.99022 & 0.00093 \\
\hline Square array with lead wall at $0.26^{\prime \prime}$ & 8 & 0.99414 & 0.00099 \\
\hline Square array with lead wall at $1.29^{\prime \prime}$ & 8 & 0.99176 & 0.00099 \\
\hline Square array without lead wall & 8 & 0.98365 & 0.00097 \\
\hline \multicolumn{4}{|c|}{ Benchmark Statistics } \\
\hline \multicolumn{4}{|c|}{ Bias $=0.00032$} \\
\hline \multicolumn{4}{|c|}{ Standard Deviation $=0.01163$} \\
\hline \multicolumn{4}{|c|}{ Variance $=0.00014$} \\
\hline
\end{tabular}

(4) State the area(s) of applicability.

The mass limits for fissionable materials applicable to the loading, unloading, storage and on-site transportation of specified fissionable material in the Large Bore, the Long Bore, the PRTR Graphite, the One Ton Sample or any cask with a maximum inner volume of $5 \mathrm{~L}$ are shown below.

$275 \mathrm{~g}$ for ${ }^{255} \mathrm{U}$, $175 \mathrm{~g}$ for ${ }^{239} \mathrm{Pu},{ }^{233} \mathrm{U},{ }^{237} \mathrm{~Np},{ }^{241} \mathrm{Am},{ }^{243} \mathrm{Am},{ }^{244} \mathrm{Cm}$, and ${ }^{247} \mathrm{Cm}$,

The Sum of Fractions method defined in Table 6.1 in PNL-MA-25 may be used to determine compliance for mixtures of fissionable material. Fissionable material more reactive than ${ }^{239} \mathrm{Pu}$, i.e., ${ }^{242 \mathrm{~m}} \mathrm{Am},{ }^{243} \mathrm{Cm},{ }^{245} \mathrm{Cm},{ }^{249} \mathrm{Cf}$, or ${ }^{251} \mathrm{Cf}$ have not been analyzed and thus are not allowed under these limits; however these materials are considered to be insignificant for the purposes of criticality safety provided the mass does not exceed the safeguards accountability limits. Pacific Northwest National Laboratory currently has none of these restricted materials in accountable quantities. These materials can only be obtained in accountable quantities as a source and thus could not be accidentally obtained. Therefore, violation of this restriction is not credible.

The 12" edge-to-edge spacing requirement is in effect between the cask and other fissionable material. Spacing requirements between the cask and other heavy metal reflectors are not necessary because the cask was proven to be subcritical with an infinite lead reflector. 
NCS Basis Memo 96-2

December 30, 1996

Page 10

(5) State the bias and the prescribed margin of subcriticality over the area(s) of applicability. State the basis for the margin.

Calculational results indicate that the overall code bias based on benchmark calculations given in Table 5 calculated using KENO-Va tracking 5000 neutrons per generation is $0.3 \mathrm{mk}$. The mean of all benchmarks is 0.9997 and the standard deviation of the mean is $12 \mathrm{mk}$. If these values are applied to the modeled scenarios using the methodology given in Reference 3, the reactivity will not exceed 0.988 including experimental error and biases. The margin of subcriticality is therefore at least $12 \mathrm{mk}$ and assumes optimum conditions and a loss of contingency error. The margin of subcriticality was calculated with a $95 \% / 95 \%$ confidence.

\section{Discussion of Loss of Contingencies}

The Large Bore, Long Bore, PRTR Graphite and One Ton Sample Cask scenarios were modeled with tolerances on each of the geometric parameters of the casks. The direction of the tolerance was chosen to create a more reactive situation such as allowing a larger mass in the cask or allowing a more reactive concentration of material. In addition, the maximum cask volume limit is set based on a spherical geometry; most casks at the Laboratory have a cylindrical bore and thus will be less reactive. Therefore, the most reactive geometric models were considered.

A loss of mass contingency error would be caused by exceeding the mass limit in the cask. This scenario was examined by modeling the minimum water reflected critical mass $\left(820 \mathrm{~g}{ }^{235} \mathrm{U}\right.$ and $530 \mathrm{~g}$ ${ }^{239} \mathrm{Pu}$ ) in each of the casks. In all cases, the margin of subcriticality was greater than $100 \mathrm{mk}$. This accident scenario was also modeled in the $5 \mathrm{~L} \mathrm{lead} \mathrm{cask.} \mathrm{The} \mathrm{result} \mathrm{was} \mathrm{a} \mathrm{subcritical} \mathrm{margin} \mathrm{of} 12 \mathrm{mk}$. Therefore, an accident where the mass limit is exceeded will not result in criticality.

An increase in the volume of the cask is not a credible accident for the Large Bore, the Long Bore, the PRTR Graphite and the One Ton Sample Casks as their geometry is known and documented and tolerances were added to the nominal dimensions when modeled. However, the use of the $5 \mathrm{~L}$ volume limit on a larger cask which does not meet this requirement is possible. Therefore, the spherical cask was modeled with the fissile material at the mass limit and at optimum concentration in an increased volume. These cases were subcritical with a margin of at least $100 \mathrm{mk}$.

An increase in the thickness of the lead shielding or stacking lead bricks around the cask will aiso not result in criticality. To ensure this, the $5 \mathrm{~L}$ cask and the Large Bore Cask were modeled at the mass limit with an critically infinite lead thickness of 28 ". The subcritical margin was greater than $100 \mathrm{mk}$ in all cases.

\section{Conclusions}

The purpose of this memo was to provide the technical bases for the subcriticality of storage and handling of fissionable material scrap of various compositions in small bore transfer casks and lead pigs with lead shielding. The analyses assumed optimum water moderation of the fissionable material 
HNF-SD-TP-SEP-063, Rev. 0

NCS Basis Memo 96-2

December 30, 1996

Page 11

located inside the casks and demonstrated subcriticality during normal operations and following the loss of a single contingency including over batching, an increase in the reflector thickness (i.e. stacking lead bricks around the cask) and an increase in the cask volume (using the mass limit for a larger cask). These analyses bound all possible loss of contingency scenarios and ensure the double contingency principle is met. In conclusion, batch limits for the amount of scrap in the Large Bore, the Long Bore, the PRTR Graphite and the One Ton Sample Casks have been determined. The limit for ${ }^{235} \mathrm{U}$ as the only fissionable material is $275 \mathrm{~g}^{235} \mathrm{U}$. The limit for other types of fissionable material except ${ }^{242 \mathrm{~m}} \mathrm{Am},{ }^{243} \mathrm{Cm}$, ${ }^{245} \mathrm{Cm},{ }^{249} \mathrm{Cf}$, and ${ }^{251} \mathrm{Cf}$ is $175 \mathrm{~g}$ of fissionable material. These limits are also valid for lead shielded casks with a maximum inner volume of 5 liters and an unlimited lead thickness. The $12^{\text {" edge-to-edge }}$ spacing requirement is in effect between the cask and other fissionable material but spacing requirements between the cask and other heavy metal reflectors are not necessary.

Concurrence:

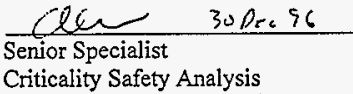




\section{HNF-SD-TP-SEP-063, Rev, 0}

iCS Sasis Mearo 96-2

Cecenber 30.1995

Page 13

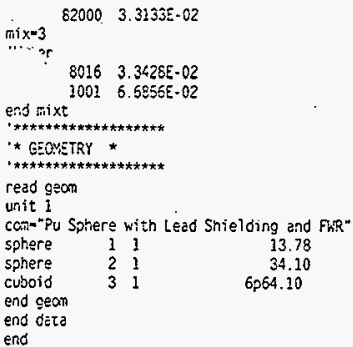

Input file for Optimum $2 \mathrm{xy}$ Concentration Determination as given in Tabie 1

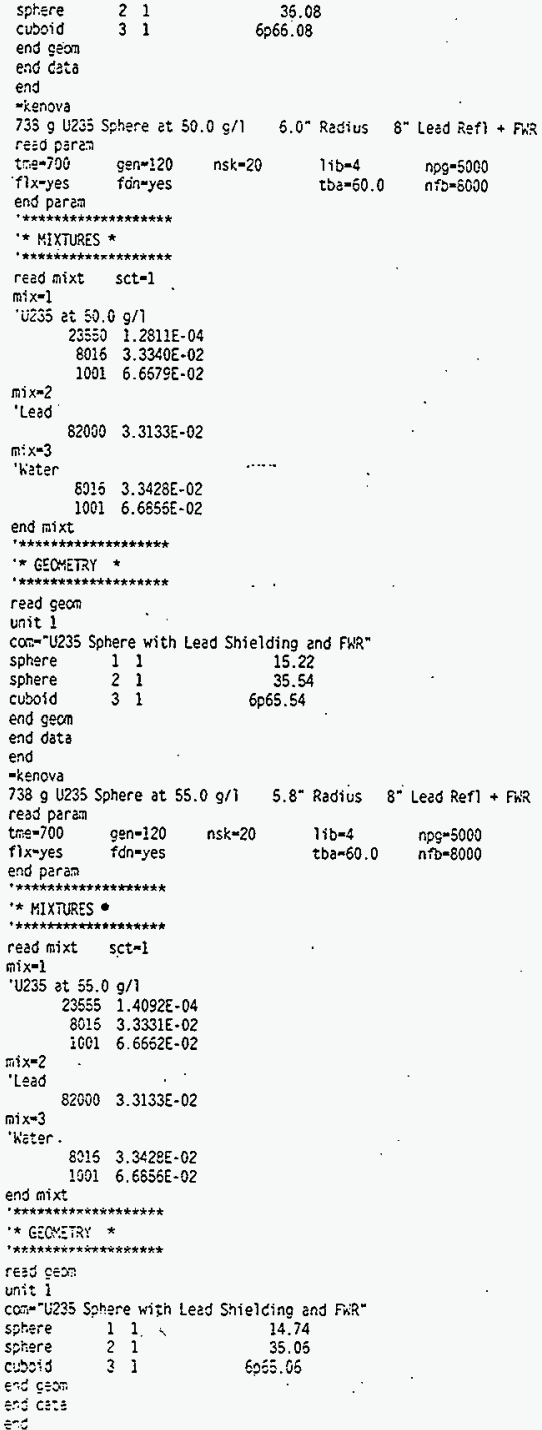


NeS Basis Meno 96.2

December 30. 1995

Paģe 14

-kenova

$736 \mathrm{~g}$ U235 Sphere at $50.0 \mathrm{~g} / \mathrm{l} \quad 5.6^{\prime \prime}$ Radius 8" Lead Ref 7 + FhR read paran

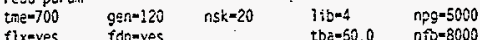

fix-yes

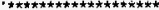

- * MIXTURES *

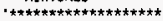

read nixt sct-1

mi $x=1$

'U235 at $60.0 \mathrm{~g} / 1$

$23560 \quad 1.5373 E-04$

$8016 \quad 3.3322 E-02$

1001 6.6544E- 02

$\operatorname{mix} x=2$

leas

mix $x=3$

$82000 \quad 3.3133 \bar{\tau}-02$

'Kater

8016 3.34Z̄BE-02

$3001 \quad 6.6856 \mathrm{E}-02$

end nixt

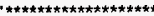

* GEOMETRY *

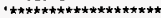

read gear

unit 1

conk"U235 Sphere with Leed Shielding and FhR"

sphere $\quad 11114.32$

sphere $\quad 21134.64$

cuboid $\quad 31$

end geom

end data

end

Input File for ${ }^{23} \mathrm{U}$ Scrap in the Large Bore Cask as given in Table 3 mitawl

ass

155

t

$\frac{t}{2 \$ 5}$

$\hat{3}^{* *}$

4** $\quad$ f2ฐ3

$\begin{array}{rr}82 & 2 \\ 19 & 9 \\ 500 & 7 \\ 0 & 0 \\ 0 & 0\end{array}$

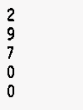

$\begin{array}{rr}3 & 4 \\ 15 & 20 \\ 0 & 0 \\ 3 & 0\end{array}$

18

0

$2235-35122 \quad-3555 \quad-3550$

$\begin{array}{rr}92235 & -35122 \\ 82000 & 1001 \\ 35122 & 293\end{array}$

$0.03 .1335 \mathrm{E}-\mathrm{G}$

$\begin{array}{crr}1 & 15.9994 & 3.9259 E+02\end{array}$

$\begin{array}{rr}3555 & 253 \\ 0.0 & 1.4097 E-04\end{array}$

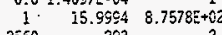

$\begin{array}{rr}3560 & 293 \\ 0.0 & 1.5373 E-64\end{array}$

$0.01 .5373 E-64 \quad 1$

$+\hat{i} 2$
2
1
+02

$5.5799 \quad 0.0000$
1.0079

1. $0079 \quad 4.3244 E+03$

$\begin{array}{rr}1 & 1.000 \\ 5.5799 & 0.0000\end{array}$

$1.0079 \quad 9.64585+03$

$\begin{array}{rr}1 & 1 \\ 1 & 0.0799\end{array}$

$\begin{array}{cc}5.5799 & 0.0000 \\ 1.0079 & 8.6438 E+03\end{array}$

end

-kenova

$820 \mathrm{~g}$ U235 Cylinder a $122.3 \mathrm{~g} / 1$ in Large Bore Increzse D

reej perati

the-700 gen=320 nsk-20 lib=4 npg=5000 nîs-\$000

flx-yes idneyses

pitryes

ribures

t5e-60.0

end paran

* MIXTURES

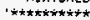

read filixt sct=1

"ruel

ini $x-1$

$351223.13355-04$

ED:E 3. उदिLE-02

ti=e0
$22000 \quad 3.3130 E-02$

'kizter

ตा $x=3$

$8016 \quad 3.3 * 28 E-02$

end gixt

1001 6. E555E:02

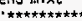

- GEOMETRY

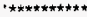

read geon

unit 1

cani-"U235 cylinder Large 5ore Cask"

$\begin{array}{llllll}\text { cylinder } & 1 & 1 & 5.5799 & 68.5800 & 0.0000\end{array}$

cylinder $31 \quad 3.5800 \quad 68.5800 \quad 0.0000$

$\begin{array}{lllll} & \text { orig } & 0.0000 & 0.0001 & \\ \text { cylinder } & 21 & 25.7650 & 95.4900 & -25.9000\end{array}$

$\begin{array}{lllll} & \text { orig } & 0.0000 & 0.0001 & \\ \text { cylinder } & 31 & 56.7650 & 125.4500 & -56.9000\end{array}$

end ceom

end tata

end

-kenova

$359 \mathrm{~g}$ U235 cylinder a $55.0 \mathrm{~g} / \mathrm{l}$ in Lorge Bore Increase 0

read paran

flx-yes

gen-120 nsk $=20$ lib-4 npg-5000 nfb-8900 end param

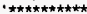

* MIXTURES

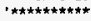

read mixt set-l

'Fuel

mix-1

$35551.4097 \mathrm{E}-04$

$8015 \quad 3.3331 E-02$

$20016.6562 \mathrm{E}-02$

tead

mi $x=2$

$82000 \quad 3.3130 E-02$

"h'ater

mix $=3$

6036 3.3428E-02

$1001 \quad 5.6856 E-02$

end $\pi i x t$

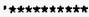

* GEONETRY

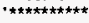

reco geon

unit $\dot{1}$

corm"U235 Cylinder Large Bore Cask

cylinder $11 \quad 5.5799 \quad 68.5800 \quad 0.0000$

cylinder $31 \quad 5.5800 \quad 68.5800 \quad 0.0000$

$\begin{array}{lllll} & \text { orig } & 0.0000 & 0.0001 & \\ 2 & 2 & 26.7650 & 95.4800 & -25.0000\end{array}$

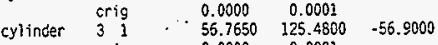

end gean

end data

end

Inptrt file for ${ }^{*} \mathrm{y}$ Strap in the Long sore Cask as given in Table 3

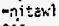

cis

$1 \leqslant 5$

255

$3 *$

$$
\begin{array}{r}
82 \\
19 \\
500 \\
0 \\
0
\end{array}
$$

$$
\begin{aligned}
& 2 \\
& 9 \\
& 7 \\
& 0 \\
& 0
\end{aligned}
$$

3
15
0
3

$\begin{array}{rr}4 & i \hat{0} \\ 20 & 0 \\ 0 & 0\end{array}$

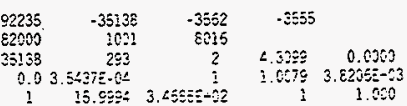


HNF-SD-TP-SEP-063, Rev. 0

ins basis kerio 96.2 Decenter 30. 1996

Page 15

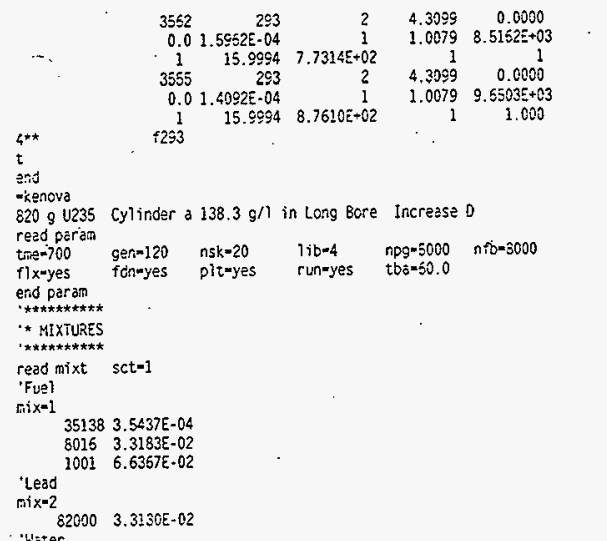

'hóter

$\operatorname{mix}=3$

8016 3.34285-02

$10016.65555-02$

end mixt

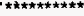

- GEOHETRY

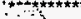

in 1

com- $=2235$ Cylincer Long Bore Cask

$4.3009 \quad 101.6000 \quad 0.0000$

cylinder $31 \quad 4.3100 \quad .101 .6000 \quad 0.0000$

$\begin{array}{llllll} & \text { orig } & 0.0000 & 0.0001 & \\ \text { cylinder } & 2 & 24.8000 & 129.2938 & -27.6938\end{array}$

$\begin{array}{lcc}24.8000 & 129.2938 & -27.6538 \\ 0.0000 & 0.0001 & \end{array}$

cylinjer 3

$\begin{array}{lcc}54.8600 & 159.2938 & -57.6933 \\ 0.0000 & 0.0001 & \end{array}$

end geom

orig

end data

end

-kenova

$369 \mathrm{~g} U 235$ Cylinder a $62.3 \mathrm{~g} / 1$ in Long Bore increase $D$

read paran

flx-yes fon-yes plt=yes run=yes tba $=60$.

end param

$* *$ MIXTURES

-***********

reed mixt sci=1

- $\tilde{t}$

ini $\mathrm{x}=1$

3562 1.5E52E-04

$8016 \quad 3.3315 E-02$

1002 6.6ร3SE.02

3िक्ष

$-i x=2$

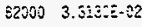

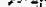

6016 3. $3425 E-02$

s.J mixt

$0016.5556 \mathrm{~F}-02$

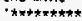

* EENzisy

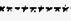

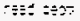

unit 1

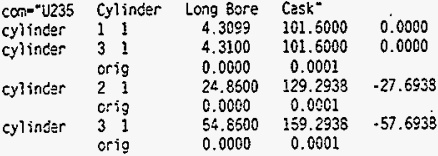

end $g=0 \pi$

end deta

end

-kenova

326 g U235 Cylinder a $55.0 \mathrm{~g} / 1$ in Long Bore Increase D

read darán

trig=700 $g \leqslant n-120 \quad n s k=20 \quad$ ijb $=4 \quad n p g-5000 \quad n f b=8000$

$f i x<y=5$

end pertas

fon-yes

pltays

run=yes

$b_{2}=50.0$

* MIXIURES

reed nixt set-1

'Fue?

mix $x-1$

$35551.4092 E-04$

$8015 \quad 3.3331 E-02$

1001 6. $5552 E-02$

lead

mix $=2$

Weter

mix -3

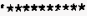

-* EFCMETRY

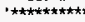

read oexm

unit 1

con="uzas cylinder Long Bore cask"

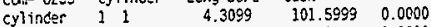

cylinder $31 \quad 4.3100 \quad 101.6000 \quad 0.0000$

$\begin{array}{lllll}\text { cylinder } 2 & 2 & 24.8600 & 129.2938 & -27.6938\end{array}$

orjg $\quad 0.0000 \quad 0.000$

$\begin{array}{lllll}\text { cylinder } \quad 31 & 54.8600 & 159.2938 & -57.6938\end{array}$

end geon

end data

end

Input File for ${ }^{23} \mathrm{U}$ Scrap in the PRTR Graphite Cask as given in

Table 3

-กitawl

055

155

t

$0.0000 \quad 0.0001$

$3^{\star \star}$

$3 *$

82
19
500
0
0

2
9
7
0
0

1

15

418

5 .

$\begin{array}{rrrr}92235 & -35185 & -3583 & -3555 \\ 82000 & 1001 & 8016 & \end{array}$

$\begin{array}{ccccc}82000 & 203 & 2 & 4.6274 & 0.0000\end{array}$

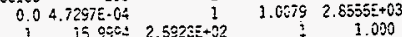

$1 \quad$ is.95\%: $2.5923 E+02 \quad 1.000$

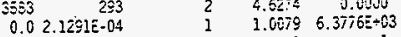

$115.9954 \quad 5.78965 \div 02 \quad 1301$

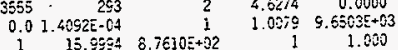

เ* $\quad$ f $2 \% 3$

$5 \div 3$ 


\section{HNF-SD-TP-SEP-063, Rev. 0}

NCS Sasis Keno $96 \cdot 2$

Decenter 30. 19e5

Paçe 16

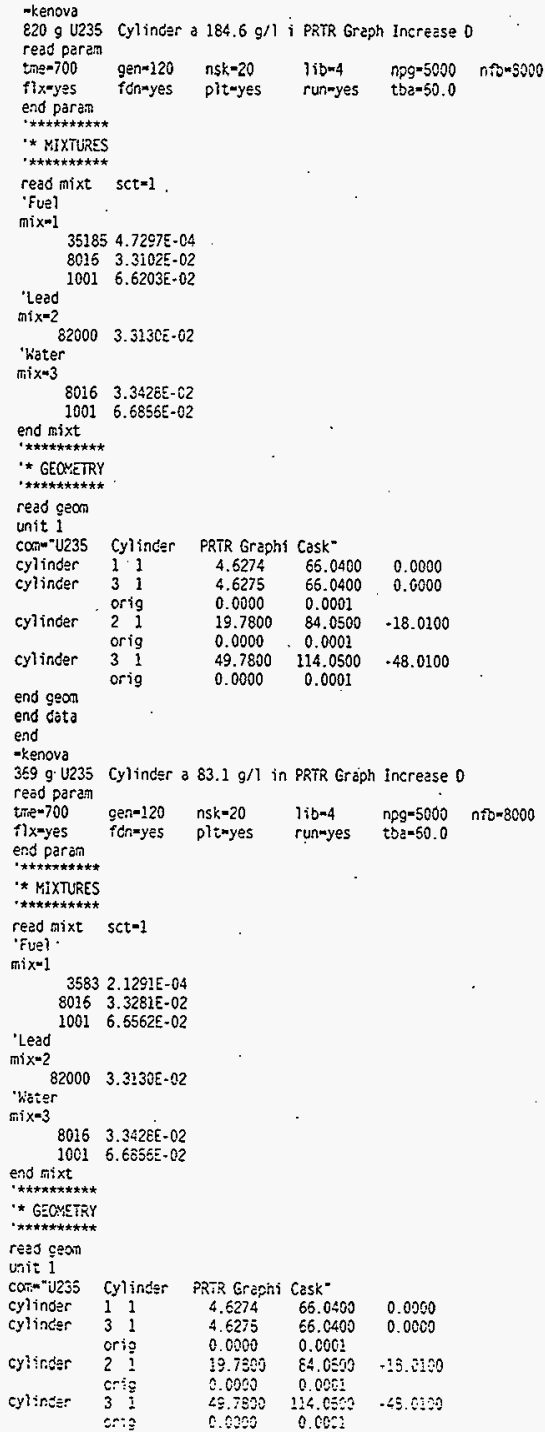

end cexi

end dat:

end

-kencva

$244 \mathrm{~g}$ U235 Cylinder a $55.0 \mathrm{~g} / 1$ in PRTR Graph Ircrease 0 read parin

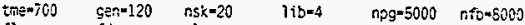
fix-yes formeyes plt-yes run-yes tba- 60.0 end peran

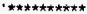

* NIXTURES

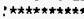

read mixt $s c t=1$

Fuel

mix $=1$

$35551.4092 E-04$ 6016 $3.333: 5-02$ 10C1 Ó. $6552 E-62$

Lead

nit $x=2$ $82000 \quad 3.31305-02$

'Weter

mi $x=3$

$8015 \quad 3.3428 E-02$ $1001-6.6856 \mathrm{E}-02$

Input Fjle for ${ }^{23} \mathrm{U}$ Scrap in the One Ton Sample Cask as given in Table 3

-nitaw?

$0 \leqslant 5$

155

82
19
500
0
0

$t$

25

$i$

tn $=700 \quad$ gen $=120 \quad n s k=20 \quad$ lib-4 nog-5000 nfb-8000
$3 \star \star$

ens

-icensuz

Q20 $\mathrm{g}$ tess Cylincer a $391.7 \mathrm{o} / \mathrm{k}$ in One Ton Increase $\mathrm{D}$ resd parth fix-yas fón-yes. pit-yes runimes t\$o 50.0

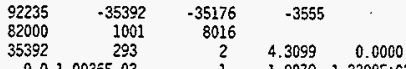

$\begin{array}{lll}1 & 1.0079 & 1.3308 E+03\end{array}$ $\begin{array}{crcrr}1 & 15.9994 & 1.2082 E+02 & 1 & 1.000 \\ 35176 & 293 & 2 & 4.3099 & 0.0000\end{array}$ $0.04 .5170 \mathrm{E}-04 \quad 1 \quad 1.00792 .0912 \mathrm{E}+03$ $\begin{array}{crcrr}1 & 15.9594 & 2.7155 \mathrm{E}+02 & 1 & 1 \\ 3555 & 293 & 2 & 4.3099 & 0.0000\end{array}$ $0.01 .4092 E-C 4 \quad 1 \quad 1.00799 .6503 \mathrm{E}-03$ exp parsen

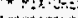


HNF-SD-TP-SEP-063, Rev. 0

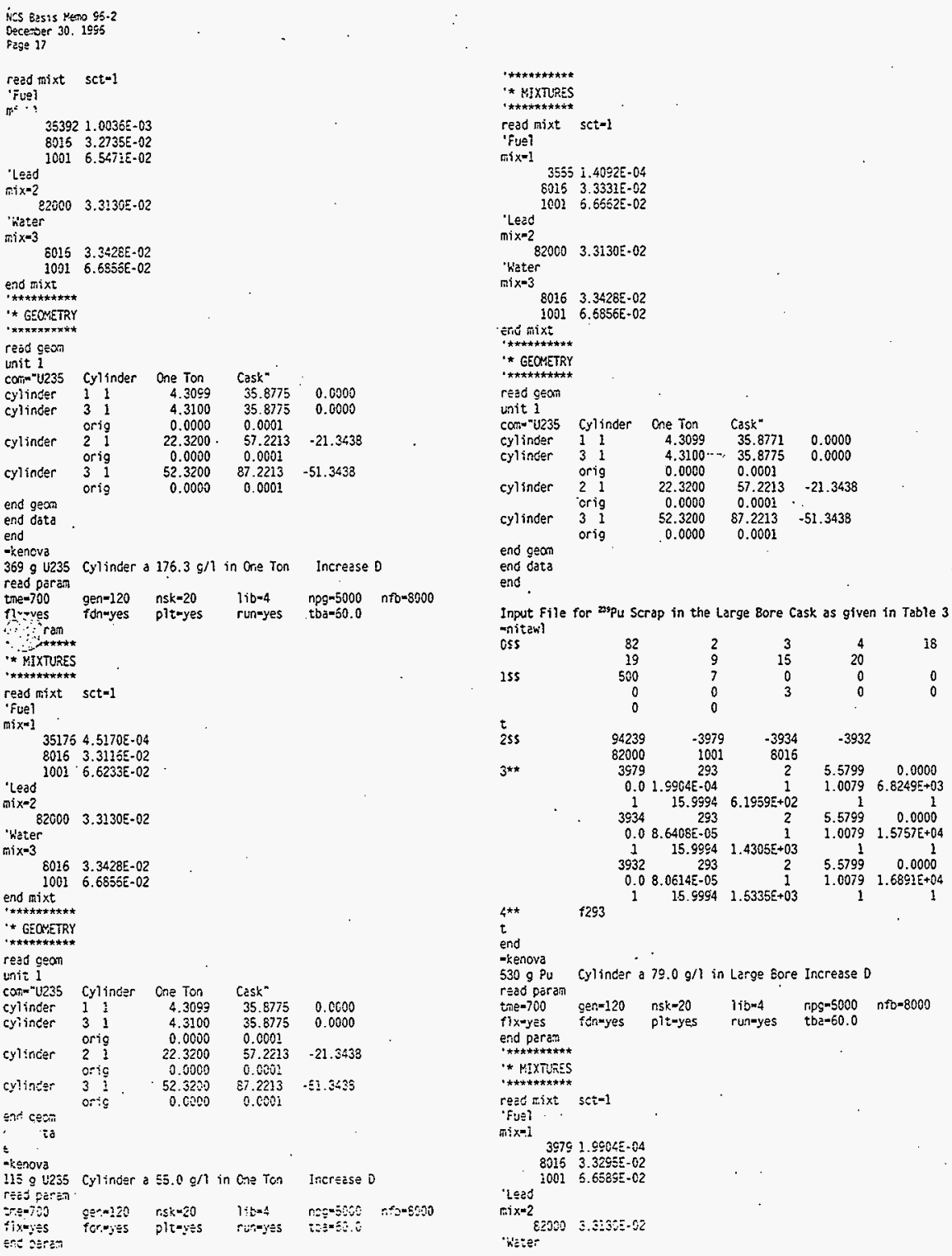


HNF-SD-TP-SEP-063, Rev. 0

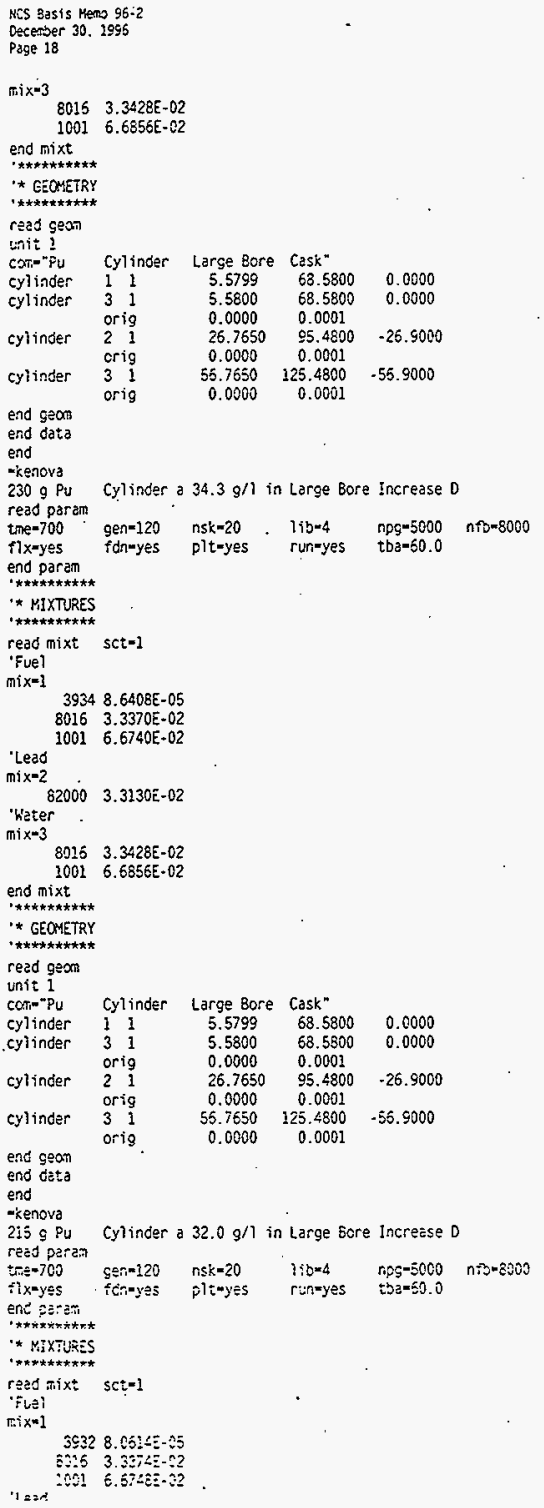

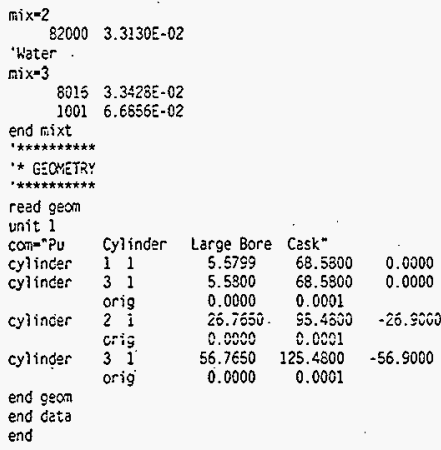

Input File for ${ }^{239} \mathrm{pu}$ Scrap in thë Long Bore Cask as given in Table 3 -nitawl

oss

155

$\begin{array}{rrrrr}82 & 2 & 3 & 4 & 18 \\ 19 & 9 & 15 & 20 & \\ 500 & 7 & 0 & 0 & 0 \\ 0 & 0 & 3 & 0 & 0 \\ 0 & 0 & & \end{array}$

$t$

2ss

$3^{\star \star}$

$4 *$

$t$

end

-kenova

$530 \mathrm{~g} p_{y}$ Cylinder a $89.4 \mathrm{~g} / \mathrm{l}$ in Lang Bore Increase $\mathrm{D}$

read paren

the $=700 \quad$ gen $-120 \quad n s k=20 \quad 1 j b=4 \quad n p g=5000 \quad n f b-8000$

$f 1 x=y e s$ fon=yes plt-yes run-yes tba -60.0

end paren

* MIXTURES

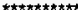

read mixt sct=1

'Fuei

mi $x-1$ 30692.25215 .04 $8016 \quad 3.32775-02$ $10016.6554 \mathrm{E} .02$

'Leas

mí $x=2$ \$2000 $3.3130 \mathrm{E}-\mathrm{Q} 2$

injer

$n i x=3$

$8015 \quad 3.34285-\imath 2$

end $-i x t$

$0015.65505-02$

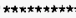

- EEONET:Y

$\pi \star \star \star * * \star *$

$r \leqslant 30$ com

vri: i=

cos=-py Eyinder Lone sore Cask" 


\section{HNF-SD-TP-SEP-063, Rev. 0}

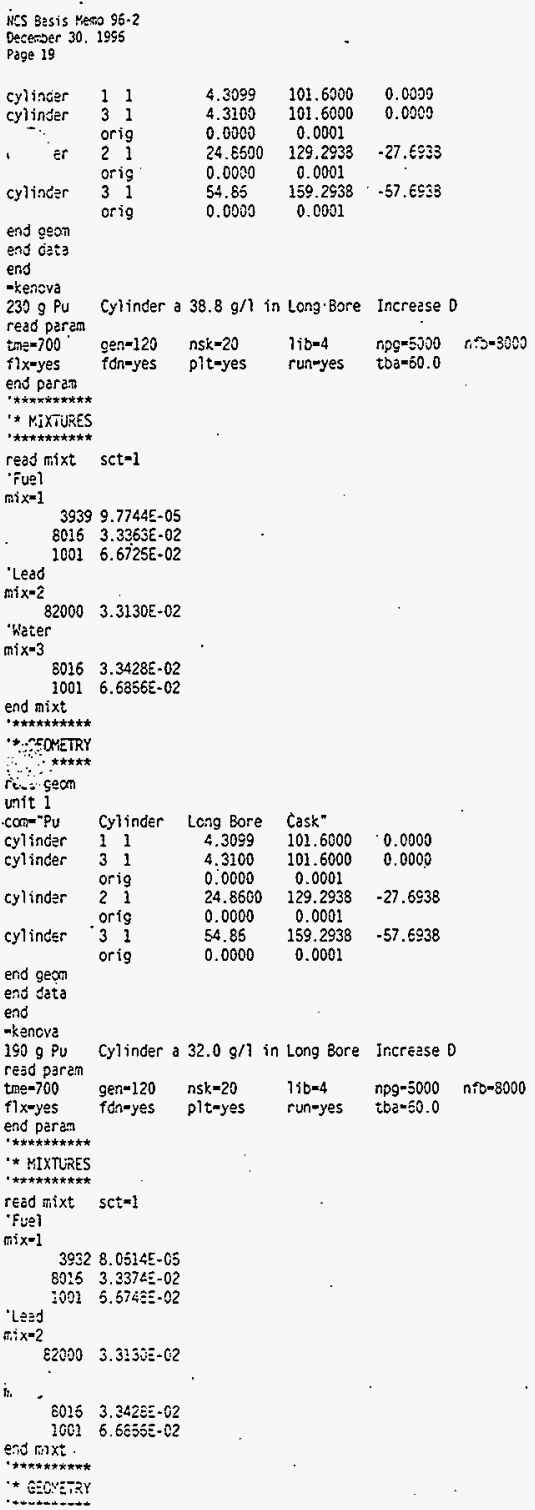

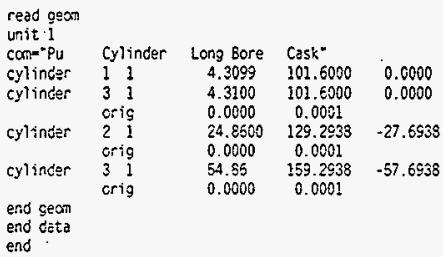




\section{HNF-SD-TP-SEP-063, REv. 0}

KCS Easis Merso $95-2$

Decenber 30. 1995

Page 20

end

-kenova

$230 \mathrm{~g} \mathrm{Pu}$ Cylinder a $51.8 \mathrm{~g} / \mathrm{l}$ in PRTR Graph Increzse 0

reas param

tine-700 gen=120 nsk-20 lib=4 npg=5000 nfb=8000

flx-yes fon-yes pit-yes run-yes tba-60.0

end peram

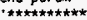

* MIXTURES

read mixt sct $=1$

'Fuel

mis $x=1$

$39521.3049 \mathrm{E}+04$

$8016 \quad 3.3341 E-02$

'Lead

$1001 \quad 6.6681 \mathrm{E}-02$

mix $x=2$

$82000 \quad 3.3130 E=02$

'keter

mi $x=3$

$8016 \quad 3.3426 \mathrm{E}-02$

$10016.6856=.02$

end mixt.

*************

- gECHeTRY

read geom

unit 1

con="Pu Cylinder PRTR Graphi Cask"

$\begin{array}{llllll}\text { cylinder } & 1 & 1 & 4.6274 & 66.0400 & 0.0000\end{array}$

$\begin{array}{lllll}\text { cylinder } 31 & 4.6275 & 66.0400 & 0.0000\end{array}$

$\begin{array}{lll}\text { orig } & 0.0000 & 0.0001\end{array}$

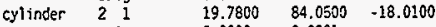

cylinder $\quad \begin{array}{lllll} & \text { orig } & 0.0000 & 0.0001 & \\ & 0 & 49.7800 & 114.0500 & -48.0100\end{array}$

$\begin{array}{ccc}3 & 0.0000 & 0.000\end{array}$

end data

end

-kenova

$142 \mathrm{~g} \mathrm{Pu}$

read param

tre $=700$ gen-120 nsk-20 jib-4 npg-5000 nfo-8000

flx-yes

end peram

for-yes pltwyes run-yes tba-60.0

'* MEXTURES

read $\operatorname{mixt}$ set

'Fuel

mixel

$39328.0614 \mathrm{E}-05$

$8016 \quad 3.3374 E-02$

$10016.6748 E-02$

'Leed

$\operatorname{mix}=2$

$82000 \quad 3.31305 .02$

'heter

$m i x-3$

$8016 \quad 3.34285 .02$

end $\pi i x \mathrm{xt}$

$10016.6856 \mathrm{E}-02$

e.t.

' $A$ GOWETEY

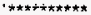

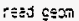

unit ?

com="Fis Cylindar. PRTR Graphi Cesk

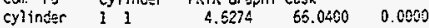

cyitiner $31 \quad 4.6275 \quad 66.0200 \quad 0.0600$

$\begin{array}{lllll} & \text { orig } & 0.0009 & 0.0501 & \\ \text { cyinsier } & 2 & 19.7600 & 64.0500 & -13.0100\end{array}$

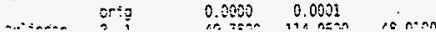

end gaom

end dete

end

Input File for "2Pu Scrap in the One Ton Sample Cask as given in Table 3

-nitew

$\operatorname{css}$

155

t

$3^{* *}$

$4^{*}$

$t$

end

-kenova

$530 \mathrm{~g} P \mathrm{u}$ Cylinder a $253.2 \mathrm{~g} / 1$ i One ton increase 0

read parant

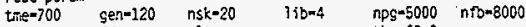

fix-yes fon-yes plt-yes runzyes tbe -60.0

end paran

* HIXTLRES

resd mixt sct-1

'Fuel

mit $x=1$

$392536.3785 E-04$

$8015 \quad 3.3001 E-02$

Lead

$10016.6001 E-02$

mix $x=2$

$82000 \quad 3.3130 \mathrm{E}-02$

'Hater
mi $x=3$

$80163.3428 \mathrm{E}-02$

$1003 \quad 6.6855 \mathrm{E}-02$

eno mixt

-* GEOMETRY

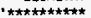

read geon

unit 1

cani-pu cylinder - One ion cask"

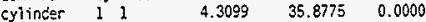

cylinder $31 \quad 4.3100 \quad 35.8775 \quad 0.0000$

$\begin{array}{lllll} & \text { orig } & 0.0000 & 0.0001 & \\ \text { cylinder } & 2 & 22.3200 & 57.2213 & -21.3438\end{array}$

orig . $0.0000 \quad 0.000$

$\begin{array}{lllll}\text { cyinder } & 31 & 52.320 & 87.2213 & -51.3438 \\ & \text { crig } & 0.0000 & 0.0001 & \end{array}$

End com

End dE:

end

-k=rova

230 o $\mathrm{Pu} \cdot \mathrm{Cy}$ inder a $110.0 \mathrm{~g} / 1$ i one ion Increase 0

read param

the-700 $\leqq=n=120 \quad n s k=20 \quad i i p=4 \quad$ ripg-50s0 nfo-5000

$f i x=y=5$ ioneyes pltwes run=yes tbo-5n.0

End ozrat

$\pi x * \pi * x+\pi m x$
16

$\begin{array}{cc}30 \pm \hat{y} & 0.0000 \\ .007 y & 2.1108 z+23\end{array}$

$4.3099 \quad 0.0000$

$.0079 \quad 4.8944 \mathrm{E}+03$

$3099 \quad 0.0000$

$0079 \quad 1.6891 E+04$ 


\section{HNF-SD-TP-SEP-063, Rev. 0}

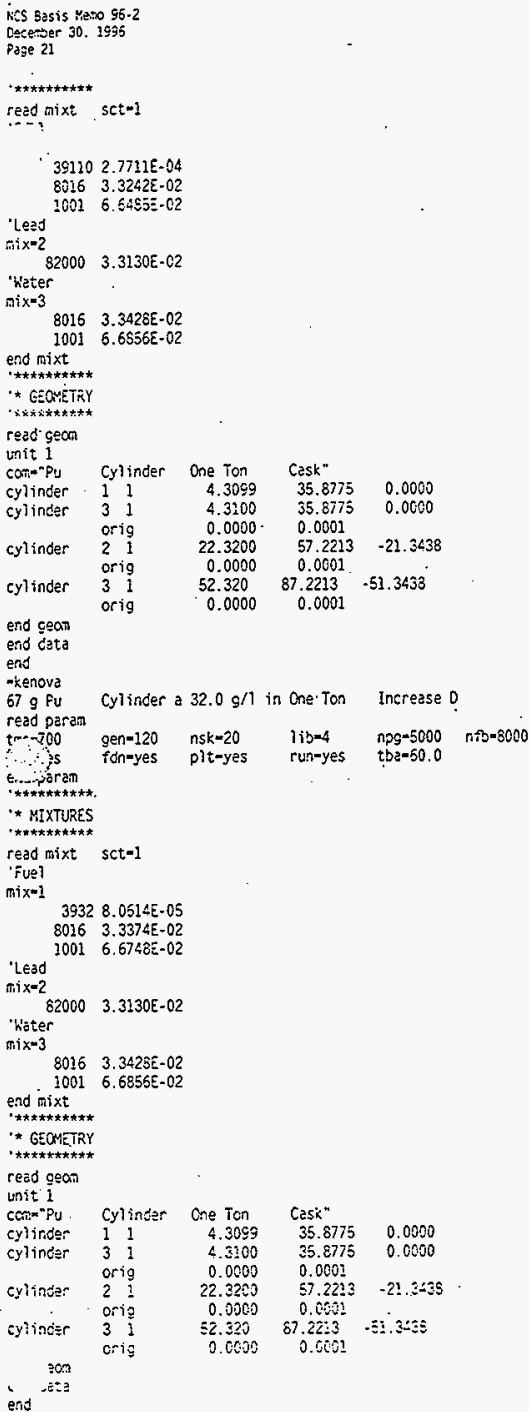

Input file for Mipu in the Large Bore Cask with Increased Lesd Reflection as siven after Table 3 anitàis?

tist

$\Sigma 2$ $\bar{z}$
155

iss

$3^{\star \star}$

$4 * *$

$t$

end

-kenova

$230 \mathrm{~g}$ Pu Cylinder a $34.3 \mathrm{~g} / \mathrm{l}$ in Letrge Bore Increase Lead Thickness to $12.4^{-1}$

recu pertan

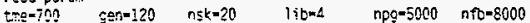
fixmyes fonmyes oli-yes run-yes tbe-60.0 end param

************

* MIXTURES

read mixt $s c t=1$

'Fuel

$\operatorname{mix}=1$

$39548.6408 E \cdot 05$ $8016 \quad 3.3370 \mathrm{E}-02$ $1001 \quad 6.6740 \mathrm{E} .02$

'Lead

mix $=2$ $82000 \quad 3.3130 E-02$

Whater

mix $=3$

$8095 \quad 3.3428 E-02$ $1001 \quad 5.6856 \varepsilon-02$

Input file for ${ }^{239} \mathrm{P}_{\mathrm{u}}$ in the 51 Cask with $8^{-}$Lead Reflector as given in Table 4

$\rightarrow$ initawl

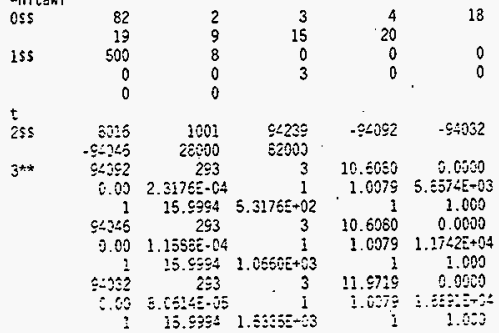


N5S basis Meno 96.2

Decencer 30.2996

Page 22

$4^{\pi \star}+293$

end

-keriove

Normal Conditions 230 g $5 t$ Fu sphere $8^{*}$ lecs refl + Fis? $r \equiv a d$ param

tite -290.0 lib $=4$ flx-yzs fon-yes nog-5000

ceei $=120$ tb $c=60.0$ nsk $=20$ nub-yes $n f b=8000$

end paran

reed gEOT

sphere 1110.608

sphere 2 I 30.928

cuboid 31 Ep 72.0

end geom

read rixt

"fu lsotopics

mix-1 94045 i.1588E-04 8016 3.3350E-02 1001 6.6701E-U2 AMTER ISOTOPICS

miา $x=3 \quad 8016 \quad 3.3426 E-02 \quad 10016.6856 E-02$

LEAD

mix $=282000 \quad 3.3133 E-02$

sct-1 end mixt

end dets

end

meneno

Loss. of Kass $450 \mathrm{G} \mathrm{SL}$ PU sphere 8 " lead refi + FhR

rees paran

tne-200.0 lib-4 flx-yes fon=yes nps -5000

gen $=120$ tbe -60.0 nsk $=20$ nub-yes nfo -8000

end poram

read gean

sphere 1110.608

sphere 2130.928

cubosd $316 p 72.0$

end geom

read mixt

-PU isOTOPICS

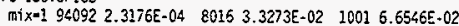
"HATER ISOTOPICS

mix=3 $80153.3426 E-02 \quad 10015.6855 E-02$

'LEAD

$m i x=282000 \quad 3.3133 \mathrm{E}+02$

sct-1 end mixt

end deta

end

-ikenova

Loss of Refl 230 g 54 Pu sphere 12" lead ref'] + Frik read param

the $=200.0$ lit $=4$ flx-yes fdn-yes npg-5000.

ceri-120 tbj $=60.0$ nsk-20 nub-yes nfo- 6000

end paren

read geom

sphere 1110.608

sphere 2141.088

cuboid $316 \% 82.0$

end geon

read $m$ ixt

PU 150TOPICS

mix-1 94046 1.35585-04 8016 3.335CE-02 $1001 \quad 5.5701 \bar{E}-02$ WATER ISOTORICS

जix=3 $80153.2426 \mathrm{E}-02$ 1001 $5.6855 \mathrm{E}-02$

$1 \pm 40$

$\operatorname{lit}=2820003.3 \$ 335-02$

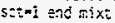

enc cast

ens

ixinova

Loss of Volute 230 o il Pu sohere s"lead refl + Fra

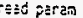

tine $=200.0$ iib $=4$ flxwes formyes nog -5000

g=?m!20 tbem50.0 nsk=20 nukmyes nt -8500

Ped fartan

racis

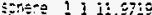

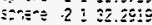

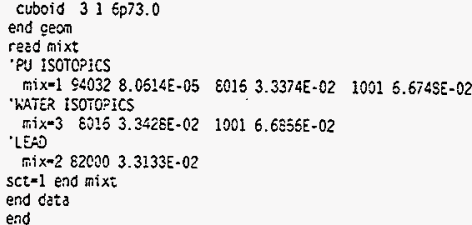




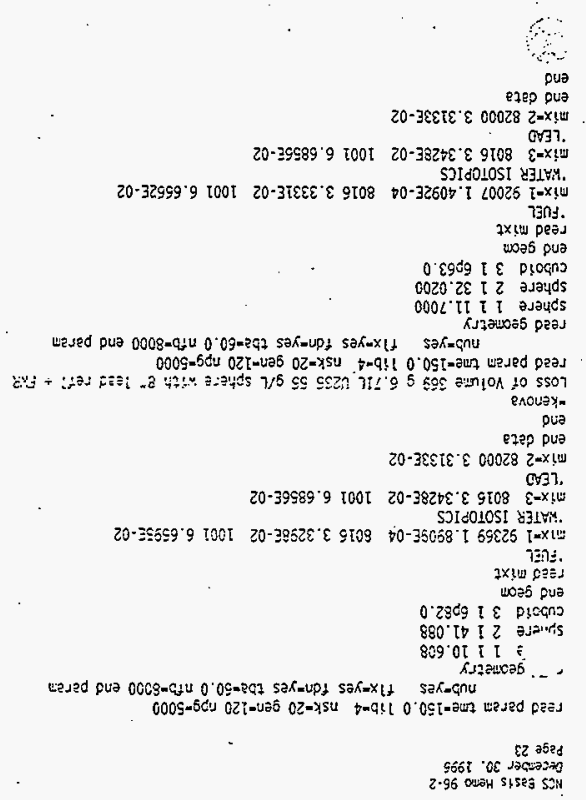


HNF-SD-TP-SEP-063, Rev. 0

NCS Gasis reno $95 \cdot 2$

Genenoer 30. 1996

Page 24

Appendix $B$ Input files for Eencranark Cases given in Table 5

Input File for Pu(NO $)_{3}$ sphere at $26.3 \mathrm{~g} \mathrm{Pu} / 1$ with Thin Steel Shell and fult hater Reflection

Input File for Pu(NO $\left.\mathrm{O}_{3}\right)$, Sphere at $34.3 \mathrm{~g} \mathrm{Pu} / \mathrm{l}$ with thin Steel Shell

Input File for $\mathrm{Pu}\left(\mathrm{NO}_{\mathrm{g}}\right)_{4}$ Sphere at $35.5 \mathrm{~g} \mathrm{Pu/l}$ with $4^{-}$Concrete Shell

Input File for $\mathrm{Pu}\left(\mathrm{NO}_{3}\right)$, Sphere at $32.8 \mathrm{~g} \mathrm{Pu} / 1$ with $4^{\text {" Concrete Shell }}$

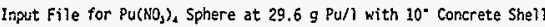

Input File for 4x4 array of $93.2 \mathrm{wty}$ Enriched Uranyl Nitrate Solution at $67.28 \mathrm{~g} J / 1$ with concrete reflection

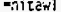

$05582 \quad 2 \quad 3 \quad 4 \quad 18$

i9 $20 \quad 9 \quad 15$

$\begin{array}{lllllll}155 & 500 & 17 & 0 & 0 & 0\end{array}$

$\begin{array}{lllll}0 & 0 & 6 & 0 & 0 \\ 0 & 0 & & & \end{array}$

$\mathrm{t}$

255 $9223592234 \quad 92235 \quad 92238 \quad 14000$

$260007014 \quad 6012 \quad 8016 \quad 1001$

$20000 \quad 22000 \quad 11023 \quad 12000 \quad 13027$

1900016000

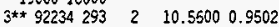

$\begin{array}{lllll}0.0 & 1.7693 E-06 & 1 & 1.0079 & 7.5125 \varepsilon+05\end{array}$

$1 \quad 16.16097 .4984 E+04 \quad 1 \quad 1.000$

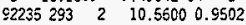

$0.0 \quad 1.6051 E-04 \quad 11.0079 \quad 8.2758 E+03$

$115.9415 \quad 8.1445 E+0211.000$

$92236293 \quad 2 \quad 10.56000 .9502$

$\begin{array}{llll}0.0 & 7.4495 \mathrm{E}-07 \quad 11.0079 & 1.7843 \mathrm{E}+05\end{array}$

$1 \quad 15.1622 \quad 1.781 \mathrm{E}+05 \quad 1 \quad 1.000$

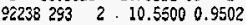

$0.0 \quad 9.1432 E-05 \quad 11.0079 \quad 1.4537 E+05$

$1 \quad 15.15171 .4502 E+04 \quad 1 \quad 1.000$

26000293125.40000 .0000

$\begin{array}{llllll}0.0 & 2.5278 E-04 & 1 & 1.0079 & 8.3939 \mathrm{E}+02\end{array}$

$1 \quad 16.7297 \quad 8.9763 \mathrm{E}+02 \quad 11.000$

$21023293+25.40000 .0000$

$0.0 \quad 3.8303 E-04 \quad 11.0079 \quad 5.5395 E+02$

$1 \quad 15.8578 \quad 5.967 \mathrm{IE}+02 \quad 11.000$

द* 1293

-kenova RoT53 4X4 array of UN solution w/o sleeve $(6) .28$ gu/ -21.12 cin óं ât (yl)

reod peram gen $=120$ nsk $=20$ npg-5000 ntb-5000

tme-700 fen-yes pit-yes run-yes tbe-50.0

fix-yes $\}$ ib $=4$ nub-yes

end param

read mixt

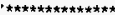

* MixTyRes *

$\cdot \star \star \star \star \star \star \star \star \star \star \star \star \star \star \star \star \star \star \star \star ⿰ 丿 ⿱ 丄 𠃍$.

$\operatorname{mix}=1$

'Fus]

c22334 $1.75535-05$

$92235,1.6051 E-04$

92236 7.4495:-07

52233 $9.14325-05$

E0:5 $3.41405-02$

$7014 \quad 4.1322-04$

1001 6.515EE-02

$5: x=2$

'Al terk

$13+27 \quad 5.25=50-02$

$-\pi i x=3$

Cencrets

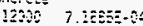

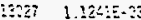

20000 8.0213E-03

$25000 \quad 2.52785-04$

19000 4. $8776 E-04$

$14000 \quad 7.713 \mathrm{GE} .03$

$10011.0401 \mathrm{E} .02$

$11023 \quad 3.83035-04$

$8015 \quad 4.23 \div 2 \varepsilon-02$

$6012 \quad 6.423 j E-03$

$7014 \quad 1.595 \hat{E}=-05$

$15000 \quad 8.28095-05$

$22000 \quad 2.919 \mathrm{EE}-05$

end mixt

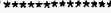

* EEOMETRY -

read geom

Lriti 1

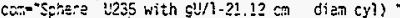

cyinder : 1 . $0.505 \quad 0.00 \quad-0.32$

$\begin{array}{llllll}\text { cylinder } 2 & 1 & 0.56 & 0.00 & -0.32\end{array}$

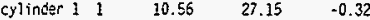

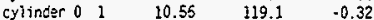

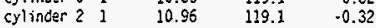

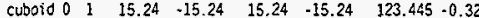

unit 2

cylinder $1 \frac{1}{1} \quad 0.505 \quad 25.40 \quad 0.00$

cylinder 21

บnit 3

$\begin{array}{lllll}\text { cylinder. } 1 & 1 & 0.505 & 5.00 & 0.00\end{array}$

cylinder $21 \quad 0.635 \quad 5.00 \quad 0.00$

unit 4

cyl inder 11

cylinder $21 \quad 10.55 \quad 0.00 \quad-0.32$

cylinder 11

cylinder 0

cylinder 2. 1

10.55

27.15

27.15

.0 .32

$\begin{array}{lll}10.96 & 119.1 & -0.32\end{array}$

cuboid 01

$\begin{array}{llllll}15.24 & -15.24 & 15.24 & -15.24 & 123.445 & -0.32\end{array}$ anit 5

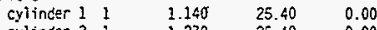

cylinder $21 \quad 1.270 \quad 25.40 \quad 0.00$

$\begin{array}{lllllllll}\text { cuboid } 3 & 1 & 15.24 & \cdot 15.24 & 15.24 & \cdot 15.24 & 25.4 & 0.0\end{array}$

unit 6

cylinder $111.140 \quad 5.00 \quad 0.00$.

sylinder $21 \quad 1.270 \quad 5.00 \quad 0.00$

$\begin{array}{llllllll}\text { cuboid } 0 & 1 & 15.24 & -15.24 & 15.24 & -15.24 & 5.0 & 0.0\end{array}$

unit 7 array-1 $\quad 0.00 .00 .0$

unit 8 array=2 $\quad 0.00 .00 .0$

unit 9 arraym $\quad 0.00 .00 .0$

tnit 10

$\begin{array}{llllllll}\text { cubsid } 0 & 1 & 121.92 & 0.0 & 0.14 & 0.0 & 5.0 & 0.0\end{array}$

$\begin{array}{llllllll}\text { cuboid } 3 & 1 & 121.92 & 0.0 & 0.14 & 0.0 & 30.4 & 0.0\end{array}$

cuboid $0 \quad 1-121.920 .00 .140 .0154 .1650 .0$

unit: 11

cuboid 01 . $25.7 \quad 0.0 \quad 122.20 .0 \quad 5.0 \quad 0.0$

$\begin{array}{lllllllll}\text { cuboid } 3 & 1 & 25.7 & 0.0 & 122.2 & 0.0 & 30.4 & 0.0\end{array}$

$\begin{array}{llllllll}\text { cubold } 0 & 1 & 25.7 & 0.0 & 122.2 & 0.0 & 31.035 & 0.0\end{array}$

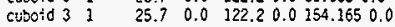

unit 12

$\begin{array}{llllllll}\text { cuboid } 0 & 1 & 173.32 & 0.0 & 25.7 & 0.0 & 5.0 & 0.0\end{array}$

$\begin{array}{llllllll}\text { clubid } 3 & 1 & 173.32 & 0.0 & 25.7 & 0.0 & 30.4 & 0.0\end{array}$

$\begin{array}{llllllll}\text { cubotd } 0 & 1 & 173.32 & 0.025 .7 & 0.031 .035 & 0.0\end{array}$

$\begin{array}{lllll}\text { ctuosid } 31 & 173.32 & 0.025 .7 & 0.0 & 154.1550 .0\end{array}$

vinit 13 errey=4 0.00 .00 .0

Liniti 14 e.rey=5 0.20 .00 .0

Clcbel unit is errey=5 0.00 .00 .0

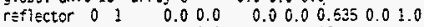

refilector $31 \quad 0.00 .0 \quad 0.00 .025 .40 .01 .0$

end gean

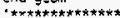

* AERY *

$r= \pm \in$ art $r E y$

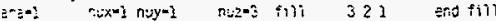


HNF-SD-TP-SEP-063, Rev. 0

NCS Basis Memo 95.2

Dexember 30. 1996

Page 25

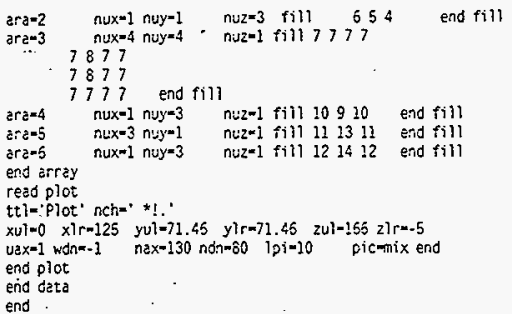

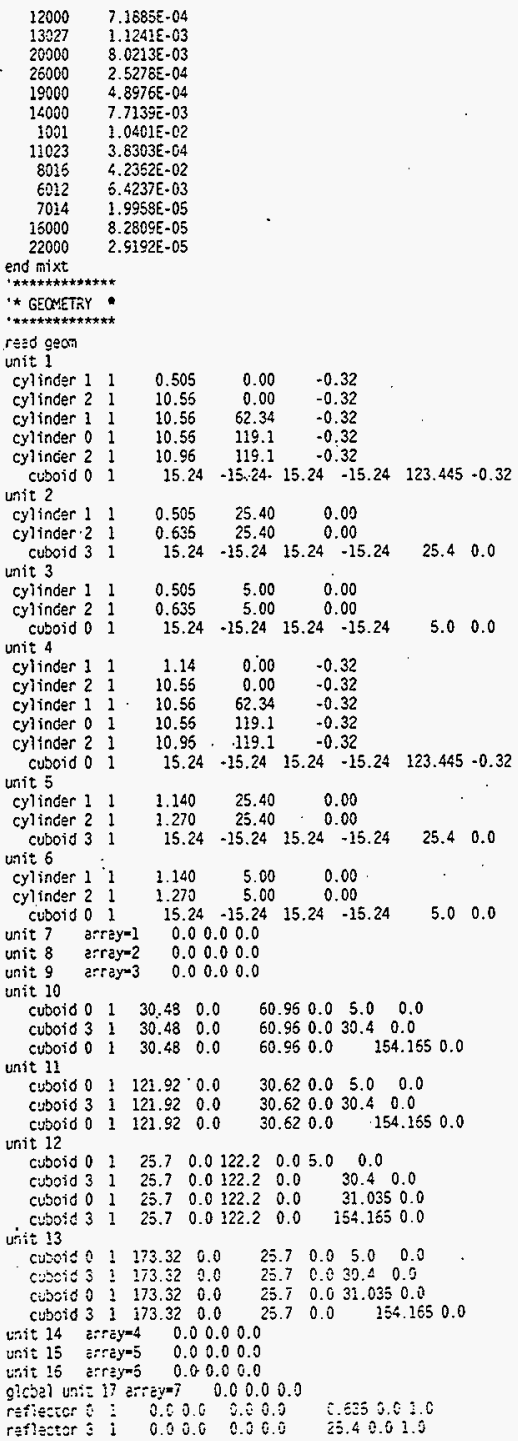


HNF-SD-TP-SEP-063, Rev. 0

itcs Easis Meno 96.2

Decender 30.1995

Page 27

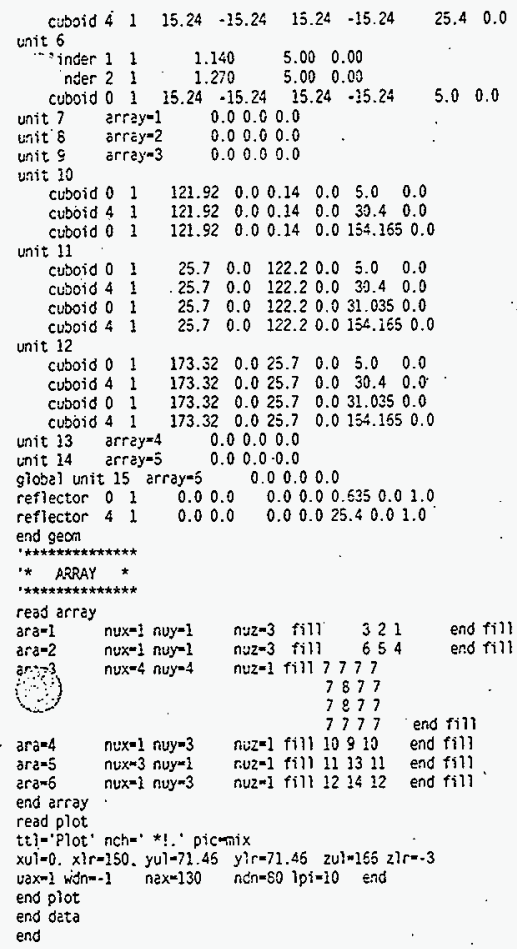

Input File for 4.31 wtz Optitnum Moderated $\mathrm{WO}_{2}$ Rods with Lead Reflector at Verious Distances

-nitaw'

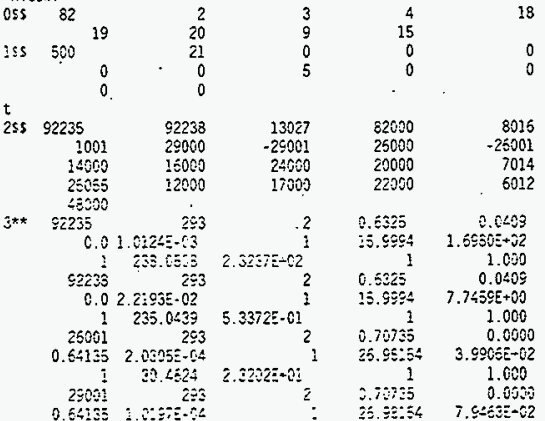

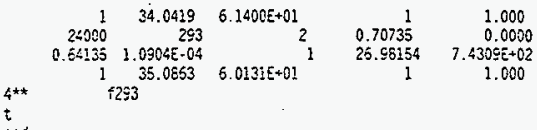

$820003.2771 \mathrm{E}-02$ 29000 1. 3909E-04

- Rubber End Caps

$\operatorname{mix}=5$

$50 \geq 2$ 3. $8435 \mathrm{E}-02$

IFO $5.1304 \mathrm{E}-02$

$200002.2527 E+03$

$150004.21835-04$

$80 \div 61.0989 \mathrm{E}-02$

$140008.4975 E-05$

end mixt

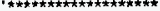

- * GONETRY *

read geor

unit I

cor:-"Single Fuel Pin"

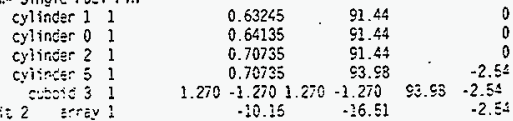

urit 2 erray

50-." $13 \times 5$ Errey of pins"

เi.it 3

cat="Critical Seperation - Water Gap"

$$
\begin{array}{lllll} 
& & &
\end{array}
$$

clobel prit 4 array 2000

Trear snell for lesá $00431 \quad 20.3200 .00 \quad 152.15-11.85107 .42-15.98$

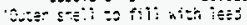

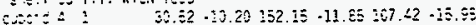


NeS Basis Mems $96-2$

Decenper 30,1996

Page 28

Neter tank cuboid $31 \quad 50.82-30.50170 .80 \cdot 30.50121 .94-30.50$ end gem

\section{read array}

ara-1 nux=8 nuy-13 nuz-1 fill 104rl $z$ thd fill

arz-2 nux=1 nuy=5 nuz=1 fill $23232 \mathrm{t}$.end fill

end orray

ers dati

end

-kenova

$4.31 \mathrm{wt}$ uO2 rods $\mathrm{P}=2.54 \mathrm{~cm}$ (Opt Mod) lead reflector 0.25 in read paran

tme-700 gen $=120$ nsk-20. iib-4 nog $=5000$

flx=yes fon=yes tbe-50.0 nid-yes nib-8000

run=yes end param

* MIXTURES *

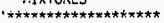

rsej mixt $\$ C t=1$

'ivel

mi $x=1$

$922351.0124 E-03$

$922382.2193 E-02$

$80164.6411 \mathrm{E}-02$

-cles

$\operatorname{mix}=2$

$130275.7878 E-02$

$14000 \quad 2.3072 E-04$

$250012.0305 \mathrm{E}-04$

29001 1.01G7E-04

25055 4.4230E-05

$120007.9981 E-04$

$240001.0904 E-04$

$220005.0729 E-05$

- Heter

$m i x+3$

$80163.3428 E-02$

$10016.6856 \mathrm{E}-02$

$17000 \quad 5.1258 E-07$

$250003.2350 E+10$

$820001.4532 E-11$

$480003.2144 E+11$

7014 4.0792E-09

Lead

$820003.2771 E-02$

$290001.3909=-04$

- Rubber End Caps

mix $x=5$

6012 3. $6415 E-02$

$10015.1304 \mathrm{E}-02$

$200002.2627 \mathrm{E}-03$

$16000 \quad 4.2183 E .04$

$80161.0959 E-02$

end mixt

$14000 \quad 8.4975 E .05$

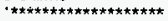

"* GEOYETRY *

-

$r \leq e d$ geon

unit 1

cot="Single Ful Pin"

$$
\begin{aligned}
& \text { cyinder I : } \\
& \text { cyincer } 0 \text { i } \\
& \text { cyisncer } 2 \\
& \text { cylines } 5 \text { : } \\
& \text { cusoid } 3 \\
& \text { Liit } 2 \text { array ? } \\
& \text { cos-" } 13 \times 8 \text { arrey of pins" } \\
& \begin{array}{ll}
0.63245 & 9.44 \\
0.64735 & 91.4 \\
0.70735 & 98.44 \\
0.70735 & 53.95
\end{array} \\
& 1.270-1.2701 .270-1.270 \quad 53.58-2.54 \\
& -10.15 \quad-15.52 \\
& \text { cor-Critical Sactation - hater Gap } \\
& \text { ciszids: }
\end{aligned}
$$

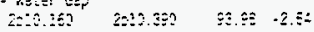

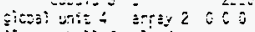$$
\text { นาi: } 3
$$

cuborg 3 I

$20.960 \cdot 0.65 \cdot 152.31 \cdot-11.69107 .42 \cdot-25.95$ - Outer shell to fill with lead cubsid $41131.18-10.85152 .31 .-11.69107 .42-15.95$ "Weter tark

$\begin{array}{lllllll}\text { cuteid } 31 & 50.82 & -30.50 & 171.12 & -30.50 & 121.54 & -30.50\end{array}$

end gear

\section{re⿻s array}

are-1 nuXwe nizy=13 nuz=1 fill 104rit tend fill

ere $=2$ nux 1 nusy $=5$ nuz=1 fill $23232 \mathrm{t}$ end $t i l l$

end array

end deta

end

-kenova

$4.31 \mathrm{wt}:$ ui2 rods $\mathrm{F}-2.54 \mathrm{~cm}$ (Opt hod) lead reflector 60.52 in read paran

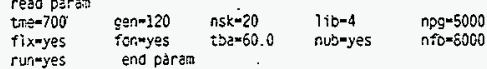

run-yes end parem

* MIXTLRES *

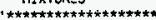

read mixt sct-1

'Fuel

$\operatorname{mix} x=1$

$922351.0124 E-03$ $922332.21935-02$ $80154.6411 E-02$

Clad

$m i x=2$

$130275.7878 E-02$

$140002.3072 E-04$

$250012.0305 E-04$

$290011.0197 \varepsilon-04$

25055 4. $4230 \mathrm{E}-05$

$120007.9981 \mathrm{E}-04$

$240001.0904 \mathrm{E}-04$

$226005.0720 E+05$

'Kater

mi $x=3$

$80153.3428 E-02$

$10016.6856 E+02$

$170005.1298 \mathrm{E}-07$

$250003.2350 \mathrm{E}-10$

$620001.4532 \mathrm{E}+13$

48000 3.2144E-11

7014 4.0792E-09

'Lead

tก $x=4$

$820003.2771 E-02$ $290001.39095-04$

'Rubber End Caps

mix $x=5$

$60223.6415 \mathrm{E}-02$

$10015.1304 E-02$

20060 2.2627E-03

$150004.21535-04$

83151 . $093 \mathrm{c}=02$

$143098.4575 E-05$

end mixt

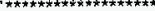

'* GEOYETRY *

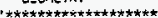

$r=\sum s=0 n$

unit i

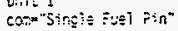

cylirite: 1

cylint:- $\hat{j} 1$

cylinet 21

cylines 5

cus:- $=31$

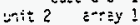

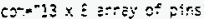

$0.52245 \quad 91.44$

$0.34135 \quad$ 91. 44

$0.70735 \quad 91.44$

$0.70735-93.08$

$1.270-1.2701 .270-1.270 \quad 53.56-2.52$

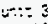

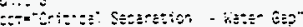


NCS Besis Meno 96-2

Cacerber 30. 1986

Page 28

'W'ater tank

cuboid $31 \quad 50.82 \cdot 30.50170 .80 \cdot 30.50121 .54 \cdot 30.50$

erio georil

read array

ar $3^{m-1} n u x=6$ nuy 13 nuz=-1

fill $104 \mathrm{rlt}$ end fill

ara-2 nux=1 nuy=5 nuz-1

iili $23232 \mathrm{t}$ end,fill

snd array

end data

end

-kenova

4.31 ht: u02 rods p-2.54 cil (Opt Mod) lead reflector 0.25 in read paran

$\begin{array}{lllll}\text { trin- }=700 & g=n=120 & n s k=20 & 1 j b=4 & n p g=5000 \\ \text { fl } x-y e s & \text { fon-yes } & \text { tbe-60.0 } & \text { nub-yes } & n f b=6060\end{array}$

run-yes end paran

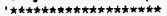

- MiXTURES *

1

read nixt sct-1

'ruel

nix 1

92235 1.0124E-03

$922382.21935-02$

8016 4.E411E-02

Cled

$m i x=2$

$130275.7878 E-02$

$140002.3072 \mathrm{E}-04$

$250012.0305 E-04$

$290011.0197 E-04$

$250554.4230 \mathrm{E}-05$

$120007.99815-04$

$240001.05045-04$

$220005.0729 E-05$

'heter

mix -3

$80163.3428 E-02$

10016.68565 .02

$17000 \quad 5.1298 \mathrm{E}-07$

$260003.2350 E-10$

$820001.4532 E-11$

$480003.2144 \mathrm{E}-11$

70144.07922 .09

'Lees

nix $x-4$

$820003.27715-02$

29000 1. 3909E-04

'Rubber End Caps

mi $x=5$

EC12 3. 6415E-02

$10015.1304 \mathrm{E}-02$

$200002.2627 \mathrm{E}-03$

$15000 \quad 4.2133 E-04$

$80161.09695-02$

end mixt.

$140008.4975 \bar{E}-05$

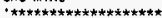

-* GECYETRY *

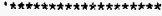

$r=30$ gexti

unit 1

con-"single Fuel Pin"

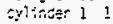

cy?istor 01

cyinder 2 i

cyinder 5

cuboid 3

unit 2 eirey

cosi="13 135 errey of pins"

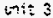

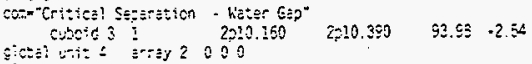

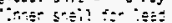

$\begin{array}{llllllll}\text { cubois } 3 & 1 & 20.980 & -0.66 & 152.31 & -11.69 & 107.42 & -15.98\end{array}$ - Outer stall to fill with lead

cubsid $41131.18 \cdot 10.86152 .31 .-11.69107 .42-15.95$ - Weter tarís

cutsid 3 ] $50.82 \cdot 30.50171 .12-30.50121 .94-30.50$ end geon

resd erray

arç=: nuxwa nuy=l3 nuz=1. fill 104r $t$ end fill

ar $z=2$ nux=1 ruy $=5$ nuz=1. fill 23232 t end fill

end errey

end dato

end

-kenova

4.31 ht: U02 rods $P=2.54 \mathrm{~cm}$ (opt nod) lead reflector 0.52 in reaj paran

tre $=700$ oen-120 nsk-20 iib=4 nog $=5000$

tix-yes fon-yes tioz-50.j nub-yes nib=8090

run-yes end param

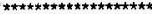

* FiXTURES *

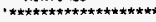

read gix: set-1

"Fue?

mix $x-1$

$\$ 22351.01245-03$

$92238 \quad 2.2193 \mathrm{E}-02$

$80154.6411 E-02$

Clad

mí $x=2$

$130275.7878 \mathrm{E}-02$

$140002.3072 \mathrm{E} \cdot 04$

$250012.0305 E-04$

$290011.0197 \mathrm{E} .04$

25055 4.4230E-05

$120007.9981 \mathrm{E}-04$

$240001.0904 E-04$

'heter

$220005.0729 \mathrm{E}-05$

mix $x=3$

8015 3.3428E-02

$10016.6856 \mathrm{E}-02$

$170005.1258 E-07$

$250003.2350 \mathrm{E}-10$

$820001.4532 E-11$

$480003.2144 E-11$

7014 4.0792E-09

'Leed

mix $=4$

$820003.2771 E=02$

$290001.3909 E-04$

- Rubber Eno Caps

mix $=5$

$60: 23.8415 \mathrm{E}-02$

$10015.1304 \mathrm{E}-02$

20000 2.2527E-03

15000 4.2183E-04

8015 1. $0989 \mathrm{E}-02$

14000 8.4975E.05

end mixt

* GEOYETRY *

.

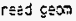

Lit: 1

Cor"Sing? FUE\} P:n" .

cylinger i 1

cylincer 01

cylinder 21

cylincer 51

cubote 31

unit 2 arry 1

coin" $13 \times 8$ arrey of gins

0.63245

0.64135

0.70735

91.44

$\quad 91.44$

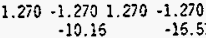

un:: 3

co-"Cristal Segeration - Water Eap" 


\section{$\llcorner\varepsilon-98$}

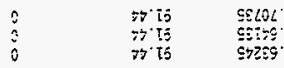

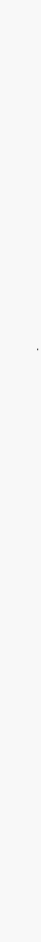

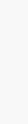

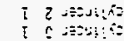

I I

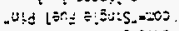
[ $1: 1,4$

$$
\text { LC:5 }
$$

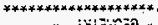

- $\mathrm{i}: 5 \mathrm{~m}=0$.

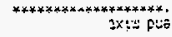

90- 3965780007

$20-35850 \cdot 75$

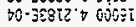

$80-3 / 292 \cdot 2 \cos 2$

$20 \cdot 330$ [' 9 ing

$20-39548$ \& 209

caxt!

sdej pus sascriy.

$70-35055 ? 100052$

$20-3 T \angle L Z \& 00 \hat{D} Z 8$

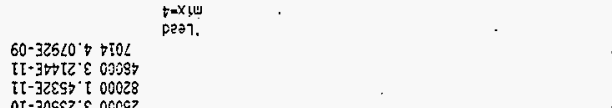

$\angle 0-3 \geq 62: 500041$

$20-39589^{\circ} \cdot 9$ toot

$20-38 z+\varepsilon \varepsilon \varepsilon 50$

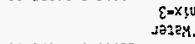

$50 \cdot 362 \angle 0 \div 5002 z$

$70-37060^{\circ}$. $000+2$

\$0-35866. $26002 i$

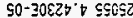

$70-36610 \cdot \tau$ I00

$\$ 0-39080 \div 30092$

$70 \cdot 32 \angle 08 \cdot 200051$

$20-38 \angle 8 L ' S$ LZOSI

$z-x ! 2$

$20-31769 \cdot 89708$

peiv.

$20-3 \varepsilon 612 \cdot 28 \varepsilon 225$

$80-37270^{\circ}$ โ $\$ \& 2 Z 5$

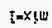

[כis].

[-70s 3x!n p?as

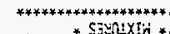

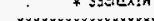

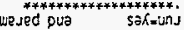

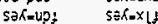

$0 Z \mathrm{~L}=\mathrm{UES} \quad 00 \mathrm{OLE}=\mathrm{At}$

wejed peas

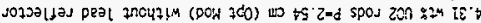

ENOUEY=

5า?

kejus pua

114) pua $a z \varepsilon z \varepsilon z 114$

tmznu gmknu t-xne z-?.je

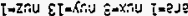

15JA5 peaj

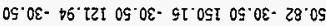

I \& pilocho

บeอs pus

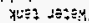

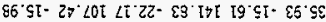

$I \geqslant$ osccis

peal y7m llts of llẹts jexro.

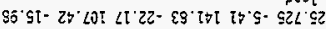
t e puectio

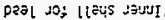

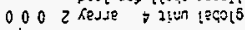

tS'Z- $86^{\circ} 86$ OST SE 1 e pigquis

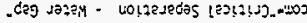

$\varepsilon ?$ qun

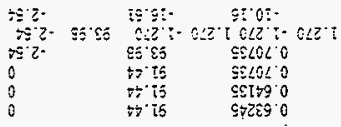

tลz-

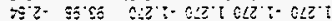

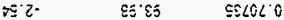

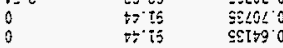

0 is

.

$60-325<0 \div+102$

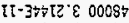

IT+3z\&5' 100028

0 - $-30 \mathrm{CSC} ? \mathrm{\varepsilon} 000 \mathrm{~g}$

$\angle 0-386 Z \mathrm{i} \subseteq 000 \angle \mathrm{L}$

$20-39589-2$ t001

$20-38 Z \div \varepsilon \cdot \varepsilon 9108$

$50-352 \angle 0.900022$

\$0-35050 700072

to-31865. $<0002 t$

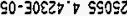

t0-32670 I 10062

$70-350 E 0 \div 2$ tocs

$70-35 \angle 0 \varepsilon^{-} \mathrm{C} 0.000 \mathrm{t}$

20 -38L8L'S LOOEL

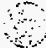

$i=x ! 11$

pet?.

$20-31$ เ

$20-3 \varepsilon 612 \cdot 28 \varepsilon Z 26$

$50-3 \div 210 \cdot t \subseteq \varepsilon 2 Z 6$

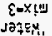

$t=x ! \ln 4$

peay.

[-x!y

tand

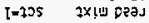

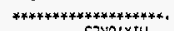

* SรYuXIs *.

******************* .

urejed pua solotinj

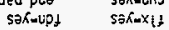

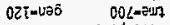

we sed pess

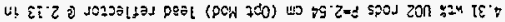

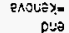

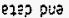

renje pusa

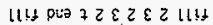

IIH pua a [J>0I II!\}

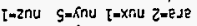

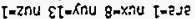

$$
\text { k57ve pisj }
$$

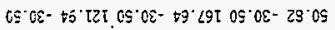

T $\varepsilon$ ploGns

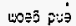

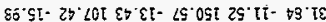

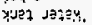

Ts $\rightarrow$ pichn

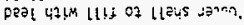

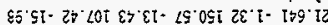

I $\varepsilon$ plocins

poal Jol liets $\mathrm{d}$.

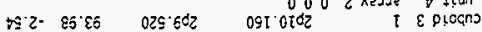




\section{HNF-SD-TP-SEP-063, Rev. 0}

XCS Easis Meno $96-2$ Decamer 30.1996

Page 30

$$
\text { cylinder } 51
$$

cuboid 3

urit 2 arroy 1

con="13 $\times 8$ array of pins"

0.70735

$0.70735 \quad 93.98$

$1.270-1.270$

9

$\begin{array}{cc} & -2.54 \\ -2.54 & -2.54\end{array}$

unit 3

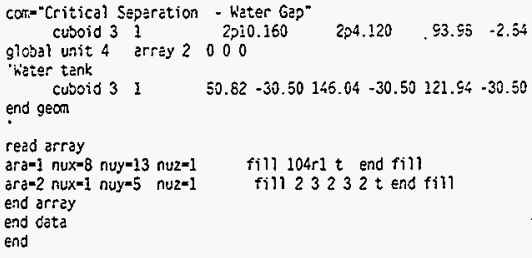

fill $104 \mathrm{r}^{-1} \mathrm{t}$ end fill

fill $23232 t$ end fill

Input File for 4,31 wty Undernoderated $\mathrm{UO}_{2}$ Rods with Lead Reflector at Various Distances

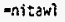


Nits Basis Heno 96.2

December 30,1995

Page 32

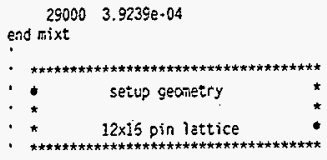

read geonatry

unit i

con:- unit pin celi

$\begin{array}{lllll}\text { cylinder } 11 & 0.63245 & 92.075 & 0.0\end{array}$

cylinder ol $0.64135 \quad \$ 2.075 \quad 0.0$

$\begin{array}{lllll}\text { cylincer } 21 & 0.70735 & 92.075 & 0.0\end{array}$

$\begin{array}{llllllll}\text { cuboid } & 31 & 0.946 & -0.945 & 0.945 & -0.945 & 92.075 & 0.0\end{array}$

:

unit 2 array $1+11.352 \quad-15.136 \quad 0.0$

care" $12 \times 16$ pin array (assembly)"

cuboid $3111.35201+11.35201 \quad 15.13601-15.1360192 .0750 .0$

unit 3

come" critical separation wôter gap"

$\begin{array}{lllllll}\text { cuboid } 31 & 11.35201 & -11.35201 & 8.125 & -8.125 & 92.075 & 0.0\end{array}$

globel unit 4 array $2 \quad 0.0 \quad 0.0 \quad 0.0$

com:- critical array geonetry (3 assemblies) -

inner cuboid shell for lead

cuboid $3125.704 \quad-3.0 \quad 145.148$ - $18.852105 .56+17.84$

'outer cuboid shell to fill $\mathrm{w} / \mathrm{iead}$.

cuboio $4135.504 \quad-13.2 \quad 145.148-18.852105 .55-17.84$

cutoold of water tank

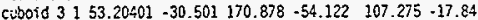

end geanetry

rees array

ard-1 nux-12 nuy=16 nuz-1 fill $192 \mathrm{r} 1 \mathrm{t}$ end $\mathrm{fill}$

zrote nux=l nuyms nuz=l fill $23232 \mathrm{t}$ end fill

end array

read stert nst=1 end stert

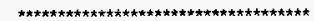

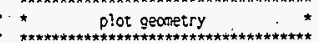

read plot

tt l' ' $x y$ pin cell by material'

ncher $0:-1$

$x y\}=0.0$ x $r-1.892$ yul-1.892 ylr -0.0 zul-50.0 21r-5ij. 0

vax=1.0 von-i. 0 nex-ê lpi-10 pichat end

ttle' $x y$ section of $12 x: 16$ assembly by material.

nche' so.'

xui $=0.0$ × $1 r=22.704$ yul -30.272 y)r=0.0 zul $=50.0$ zir $=50.0$

Lex=1.0 venm-1.0 nex-100 ipi=10 picmet ens

¿tl-' xy section of cricicai errey by materizi'

nche" " ce.*

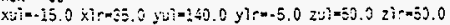

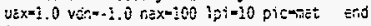

ti] -' $x z$ section of critical array by meteriel'

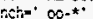

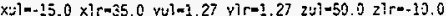

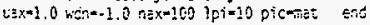

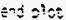

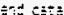

ats

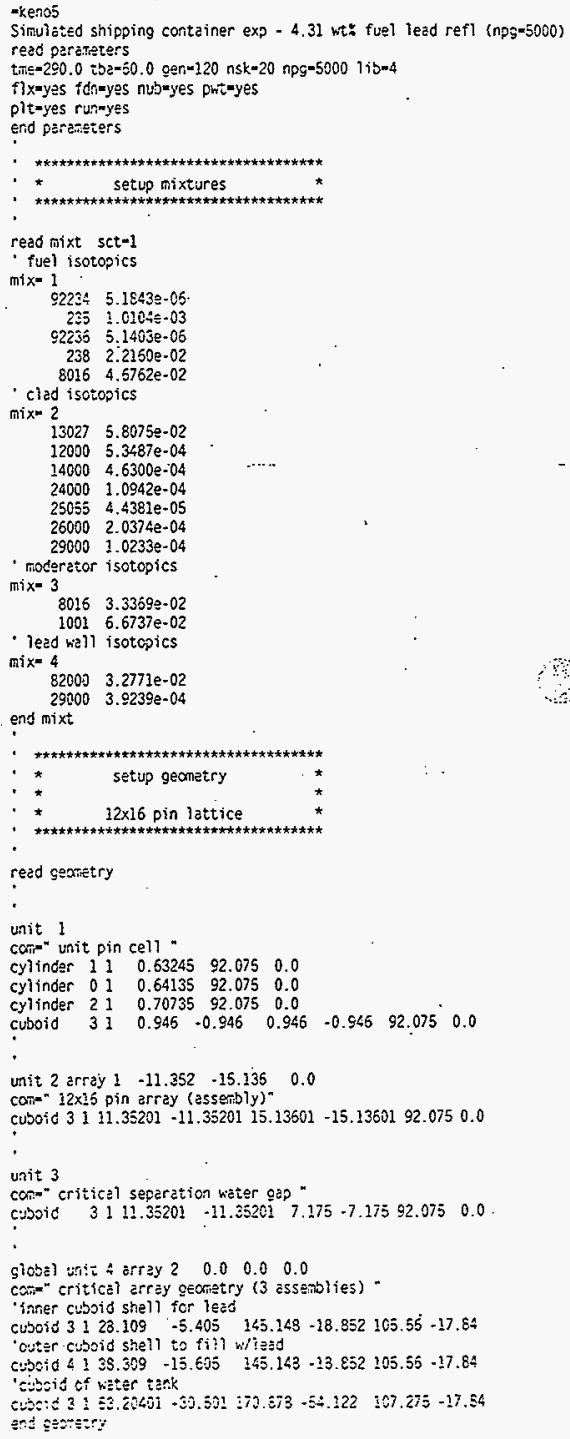



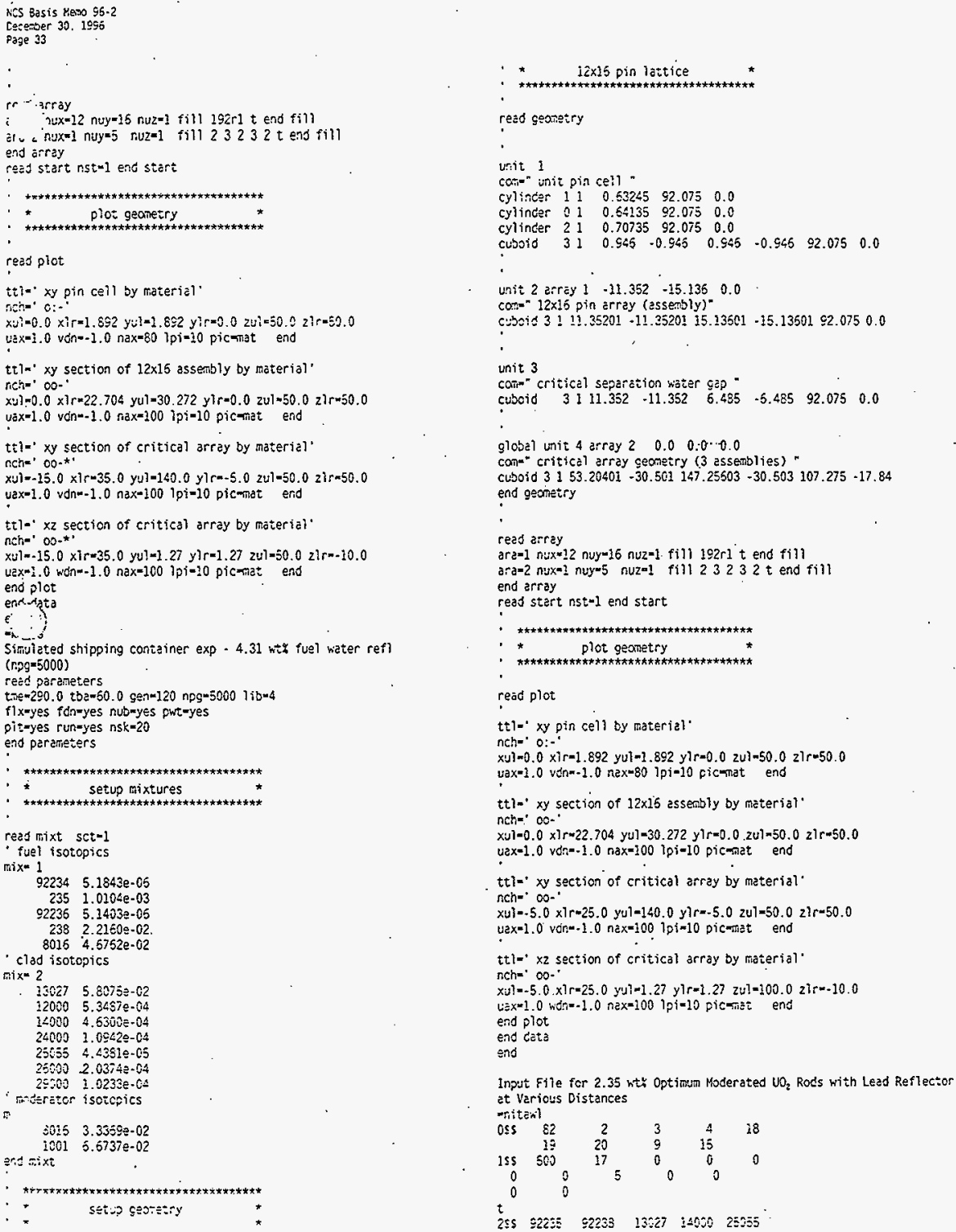
NCS bas is Meno 96.2

Cesender 30, 1990

Page 34

$$
\begin{aligned}
& 29000-25001 \quad 12000 \quad 24000 \\
& 49030 \quad 25090-25001 \quad 22000 \\
& 60151001 \quad 17000 \quad 82000 \\
& \begin{array}{llllll}
3 * * & 92235 & 293 & 2 & 0.5588 & 0.0897
\end{array} \\
& 0.0 \quad 4.9828 E-64 \quad 115.9894 \quad 3.1135 E+72 \\
& 1 \quad 238.0508 \quad 4.3490 \mathrm{E}+02 \quad 11.000 \\
& \begin{array}{llll}
92235 & 293 & 2 & 0.55590 .0597
\end{array} \\
& \begin{array}{lllll}
0.0 & 2.0033 E-02 & 1 & 15.9054 & 7.5655 \mathrm{E}+00
\end{array} \\
& 1 \quad 235.0435 \quad 2.5507 \mathrm{E}-0 \mathrm{1} \text { 1 } 1.000 \\
& \begin{array}{lllll}
25001 & 293 & 2 & 0.6350 & 0.0000
\end{array} \\
& \begin{array}{lllll}
0.5563 & 2.0305 E-04 & 1 & 26.58154 & 3.9906 E+02
\end{array} \\
& 130.4624 \quad 2.3202 E+01 \\
& 20001203 \quad 2 \quad 0.63500 .0000 \\
& \begin{array}{lllll}
0.5588 & 1.0197 \mathrm{E}-04 & 1 & 25.98254 & 7.94635-02
\end{array} \\
& 134.0419 \quad 6.1400 \mathrm{t}+01 \\
& \begin{array}{lllll}
24000 & 2 \geqslant 3 & 2 & 0.6350 & 0.0000
\end{array}
\end{aligned}
$$

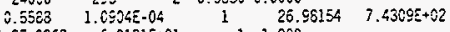

$$
\begin{aligned}
& 135.0863 \quad 6.0131 \mathrm{k}+01 \quad 11.000 \\
& 4 * \pm 293
\end{aligned}
$$$$
t
$$$$
\text { end } 2.35 \text { wt\% } 102 \text { rods wits lead refiector at } 0.00 \text { in }
$$$$
2.35 \text { wt: }
$$$$
\text { tine-700 gen } 120 \text { nsk-20 npg-5000 nro- } 8000
$$$$
\text { flx-yes form-yes plt-yes rur }=y \text { es tba }=60.0
$$$$
\text { nubveyes lib=4 }
$$

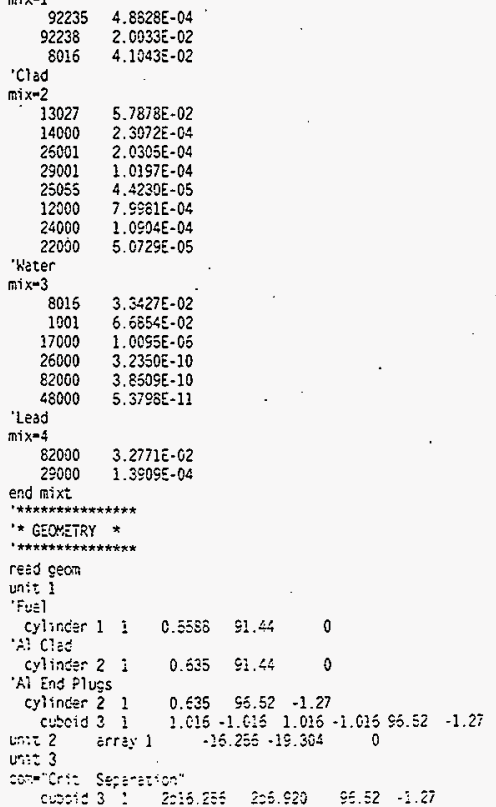

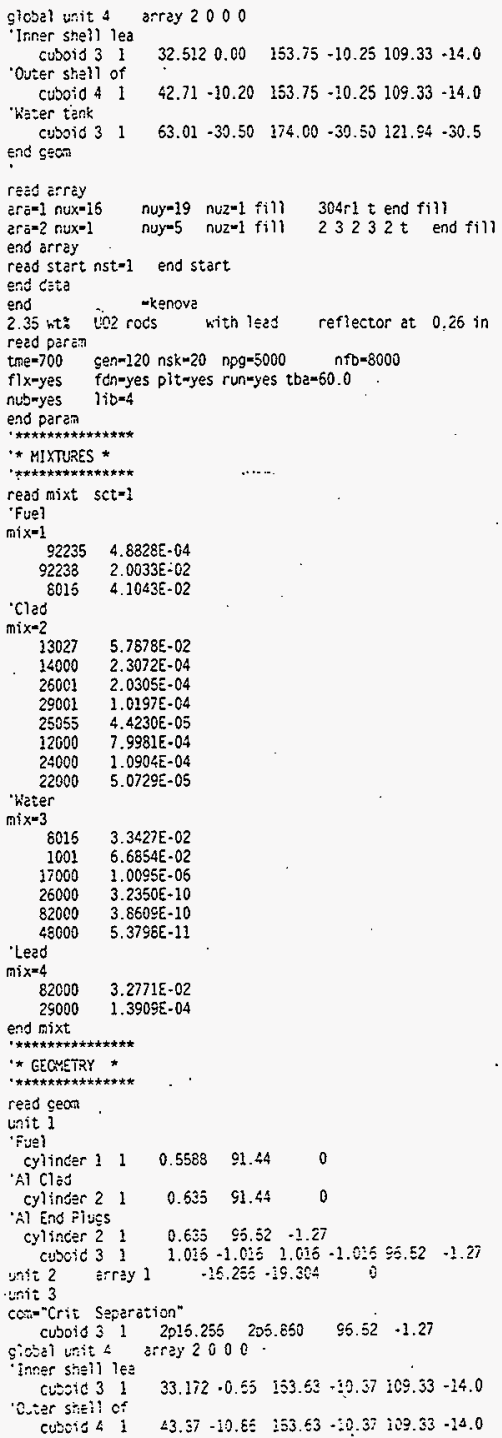


HNF-SD-TP-SEP-063, Rev. 0

HCS Sasis Keno $95 \cdot 2$

Dexerber 30.1995

Poge 36

Input File for 2.35 wt: Undermoderated $\mathrm{NO}_{2}$ Rods with Lead Reflector at Various Distances

-nitzhl

as 82

is5 $500^{19}$

2
20
17
0
0

17

3
9
0
5

$t$

\begin{tabular}{|c|c|c|c|}
\hline \multirow{5}{*}{$2 \leqslant s$} & & & \\
\hline & $\$ 2235$ & 92238 & 13927 \\
\hline & 29000 & -29001 & 12000 \\
\hline & 48000 & 26000 & -26001 \\
\hline & 8016 & 1001 & 17000 \\
\hline \multirow[t]{15}{*}{$3^{* \star}$} & 92235 & 293 & 2 \\
\hline & 0.0 & 4.8828E-04 & 1 \\
\hline & 1 & 238.0509 & $4.34905+02$ \\
\hline & 92238 & 293 & 2 \\
\hline & 0.0 & $2.0033 \bar{E}-02$ & 1 \\
\hline & 1 & 235.0439 & $2.8517 E-01$ \\
\hline & 26001 & 293 & 2 \\
\hline & 0.5583 & 2.0305E-04 & $I$ \\
\hline & 1 & 30.4624 & $2.3202 E+01$ \\
\hline & 29001 & 293 & 2 \\
\hline & 0.5558 & $1.0197 \mathrm{E}-04$ & 1 \\
\hline & 1 & 34.0419 & $6.1400 \mathrm{E}+0 \mathrm{I}$ \\
\hline & 24000 & 293 & 2 \\
\hline & 0.5588 & 1.0904E-04 & 1 \\
\hline & 1 & 35.0853 & $6.0131 \varepsilon-01$ \\
\hline $4^{* \star}$ & & 7293 & \\
\hline
\end{tabular}

$t$

-kencva

2.35 wt: U02 Rods $p=1.684$ (Undermod) leed refiector 0.00

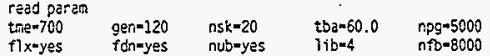

end perem

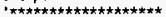

** MIXTURES *

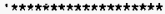

read tiixt sct-i

'Fuel

$\operatorname{mix} x+1$

$922354.88285-04$

$022382.0033 \mathrm{E}-02$

$80164.1043 \mathrm{E}-02$

Clad

$\operatorname{mix} x=2$

$13027 \quad 5.7878 E-02$

$140002.3072 E-04$

$260012.0305 E-04$

$290011.0197 \mathrm{E}-04$

25055 4.4230E-05

$120007.9981 E-04$

$240001.0904 E .04$

22000 5.0729E-05

- hiater

mi $x=3$

$80363.3427 E-02$

$10016.6554 E-02$

$170008.4931 E-08$

$250002.5580 \mathrm{E}-07$

$220001.4532 \mathrm{E}-11$

$48000 \quad 5.35735: 12$

LeEs

aix $x$

820150 3.2773E-02

29ง00 $1.3909 E \cdot 64$

end rixt

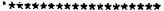

- GECNeinr *

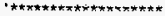

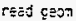

गri:!

$20.98154 \quad 3.5906 E+02$

$1 \quad 1.000$

$\begin{array}{rr}4 & 18 \\ 15 & \\ 0 & 0 \\ 0 & 0\end{array}$

cylinzer 11

Al Clad

cylincer 21

-Al End Plugs

cylinder 21

cuboid 31

unit 2 arrzy 1

con" "Center Cluster"

unit 3 errey 2

con=" End Clusest"

unit 4

cori="Critical Separation - Weter Gap

$$
\text { cuboid } 31
$$

$0.20 \leqq 3$

0.5588

15.0994

$\begin{array}{rr}0.5558 & 1\end{array}$

$15.9994 \quad 7.5886 \mathrm{E}+09$

$\begin{array}{rr}1 & 1.000\end{array}$

$\begin{array}{lr}1 & 1.000 \\ 0.5350^{1} & 0.0000\end{array}$

$26.98154 \quad 7.9463 E+02$

$0.5350^{1} \quad 1.000$

$25.98154 \quad 7.4305 E+02$

globail unit 5 zrray 3 2015.156

Inser smell lead cuboid 31

- Outer shell of lead cuboid 41

kater tank

end gean

read array

end array

end data

$\begin{array}{rrr}0.5588 & 91.44 & 0 \\ 0.635 & 91.44 & 0 \\ 0.635 & 95.52 & -1.27 \\ 400.842 & 95.52 & -1.27 \\ -15.156 & -19.366 & -1.27 \\ -15.156 & -16.64 & -1.27\end{array}$

cuboid $31 \quad 60.81-30.50156 .71-30.50127 .02-30.50$

ar a-1 nux=18 nuy-23 nuz-1 fill 414rl t end fill

efa-2 nux-18 nuym-20 nuz-1 firt $360 \mathrm{rl}$ t end fill

ara-3 nux=1 nuy=5 nuz=1 fill $34243 \mathrm{t}$ end fill

end

rikenovs

2.35 wt: UO2 Rods P-1.684 (Undemod) lead reflector 0.26

read paran

triz $=700 \quad$ gen $-120 \quad n s k=20^{\circ} \quad$ tba $=60.0 \quad n p g-5000$

fix-yes fon-yes nub-yes lib-4.' nfb $=8000$

end param

.

'* MIXTURES *

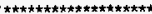

read mixt sct=1

'Fuel

$\mathrm{mix}=1$

$922354.8828 \mathrm{E}-04$

92238 2.0033E-02

$80164.1043 \mathrm{E}-02$

'cleo

$\mathrm{mix}=$ ?

$139275.7878 E-02$

j $40002.3072 \mathrm{E}-04$

25001 2.0305E-04

29201 1.0197E-04

25055 4.4230E-05

$120007.9981 E-04$

$240001.0904 E-04$

thizer

22000 5.07.29E-05

mix $=3$

8016 3.3427E-02

$10016.6854 \mathrm{E}-02$

$170008.4931 \mathrm{E}-0 \mathrm{~B}$

25000 2.588CE-07

82000 1.4532E-11

48000 5. $3573 \mathrm{E}-12$

'L슨ㅇㅇ

mix-4

82000 3.2771E-02

end $m i x t$

$250001.390 \%=02$

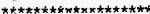

* EEQVETAY

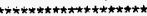

rejd çom

vrit 1

'Fuㄴ?

eyijecier 1 :

$\hat{i} .5553$

\$2. 44

3 
NCS Easis Mato 55.2

Decenter 30 . 1905

Pag* 37

cylinder 21

Al End Plugs

- -ylinder 2

euboid 31

L.... 2 array 1

coñ-"Center Ciuster"

urit 3 array 2

con-"End Cluster"

unit 4

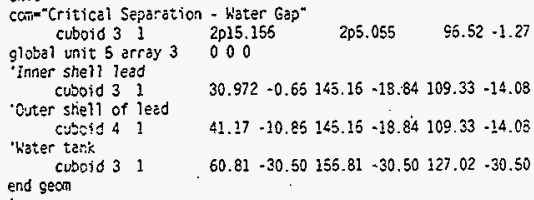

read array

arz-1 nux 18 nuy-23 nuz-i fill $414 r 1 t$ end fill

ar $z=2$ nux $=18$ nuy 20 nuz $=1$ fill $350 r 1$ t end $f i l l$

ora-3 nux=1 nuy $=5$ nuz-1 - fill 34243 t end $f 111$

end array

end data

end

-kenova

2.35 wt: to2 Rods $9+1.684$ (Undemod) lead reflector 61.29

read paran

tra $=700$ gen-120 nsk $=20 \quad$ tbe $=60.0 \quad$ ngc $=5000$

flx-yes fdn-yes nub-yes lib-4 nfb-8000

end param

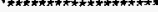

DIXTURES -

-

Fuel

$\operatorname{six}=1$

$922354.6523 E-04$ 92238 2.0033E-02 8016 4.1043E.02

'Clad

mix $x=2$

$130275.7378 E-02$

$140002.3972 E-04$

$250012.0305 E-04$

$290011.01975-64$

25055 4. $42305-05$

$120007.9581 \mathrm{E}-04$

$240001.0904 E-04$

$220005.0729 E-05$

'kater

mi $x=3$

$80153.34275-02$

$10016.655 \div E-02$

17000 8. $4931 \mathrm{E}-68$

$250002.5880 E-67$

$\$ 2000 \quad 1.4532 E-11$

43000 5. $35735-12$

'Lead

$\min x=4$

end mix:

$82000 \quad 3.2 \overline{7} 7 \overrightarrow{\mathrm{L}}-\mathrm{s} 2$

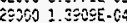

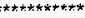

- GEFETRY *

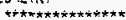

- $\mathrm{gacm}$

บnx: 1

cylindar 11

औi C?

civinger $z$ :

at ent fivos

$\begin{array}{rrr}0.635 & 91.44 & 0 \\ 0.635 & 96.52 & -1.27 \\ 400.842 & 95.52 & -1.27 \\ -15.155 & -19.356 & -1.27 \\ -15.155 & -16.84 & -1.27\end{array}$

0

1.27

$-1.27$

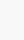

.

yios

$$
\text { ? }
$$

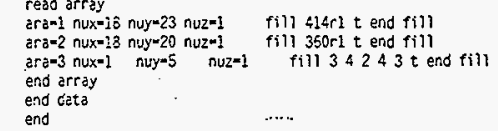

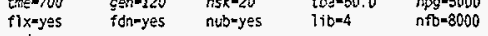

$\begin{array}{lll}0.5553 & 51.44 & 0 \\ 0.3 \pm 5 & 51.24 & 0\end{array}$

$\begin{array}{rrr}0.635 & \$ 6.52 & -1.27 \\ 400.242 & \$ 6.52 & -1.27 \\ -15.156 & -19.366 & -1.27 \\ & & -1.27\end{array}$

1.27

1.27

$-1.27$

- Neter Gap 000

$33.588 \cdot 3.28 \quad 143.55 \cdot 20.45109 .33 \cdot 14.08$ $43.79-13.48 \quad 143.55-20.45109 .33-14.08$ $60.81 \cdot 30.50153 .59 \cdot 30.50127 .02 \cdot 30.50$. 


\section{HNF-SD-TP-SEP-063, Rev. 0}

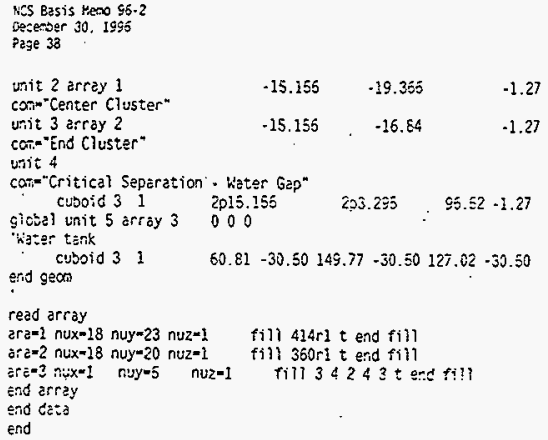


HNF-SD-TP-SEP-063, Rev. 0

NCS Bastis Merno 96-2

Decernber 30, 1996

Page 39

- Appendix B Input Files for Benchmarks used for the Statistical Analysis of the Calculations in this Basis Memo

input File for "Prpu Wizter Reflexted Critical Mass as given in Table 5. $\rightarrow$ aitew!

oss 82234181991520

iss 500120000090000

255 $\quad 94239 \quad+23901 \quad-25902 \quad-23903 \quad-23904$ $\begin{array}{llll}-23905 & -23906 & -25908 & -23911\end{array}$ $-25914$

10018016

$\begin{array}{llllll}3 . * & 23901 & 293 & 3 & 17.540 & 0.000\end{array}$ $0.06 .1468 \mathrm{E}-5$ S 1 1.0079 2.2161E4 $\begin{array}{lllll}15.9994 & 2.0119 E 3 \quad 1 & 1.000\end{array}$ $\begin{array}{lllll}23902 & 293 & 3 & 15.700 & 0.000\end{array}$ 0.0 s.3637E.5 1 1 1.0079 1.62\$nE $\begin{array}{lllll}1 & 15.9994 & 1.478053 & 1 & 1.000\end{array}$ $\begin{array}{lllll}25903 & 293 & 3^{\prime} & 15.130 & 0.000\end{array}$ $25903 \quad 293 \quad 3 \quad 15.13000 .000$ $\begin{array}{llll}1 & 15.9994 & 1.2708 E 3 \quad 1 \quad 1.000\end{array}$ $\begin{array}{lllll}23904 & .293 & 3 & 15.100 & 0.000\end{array}$ $\begin{array}{llllll}0.0 & 9.7492 \mathrm{E}-5 & 1 & 1.0079 & 1.3962 \mathrm{E}\end{array}$ 1. 15.9994 1.2676E3 I 1.000 $\begin{array}{lllll}25905 & 293 & 3 & 14.370 & 0.000\end{array}$ $0.01 .1966 \mathrm{EA}, 1$ 1.0079 $1.1371 \mathrm{E}$ $\begin{array}{llllll}1 & 15.9994 & 1.0323 E 3 \quad I \quad 1.000\end{array}$ $\begin{array}{llllll}23906 & 293 & 3 & 15.250 & 0.000\end{array}$ $0.0 \quad 1.8390 \mathrm{E}-4 \quad$ I $1.0079 \quad 7.3891 \mathrm{E} 3$ $115.99946 .7081 E 2,1.000$ $\begin{array}{lllll}23908 & 293 & 3 & 12.640 & 0.000\end{array}$ 0.0 2.5192E-4 I $1.0079 \quad 5.3867 E 3$ $\begin{array}{llllll}1 & 15.9994 & 4.8903 \mathrm{E2} \quad \text { I } & 1.000\end{array}$ $\begin{array}{lllll}23911 & 293 & 3 & 12.210 & 0.000\end{array}$ $0.07 .4316 \mathrm{E}-4 \quad 1 \quad 1.0079 \quad 1.8080 \mathrm{~EB}$ l 15.9994 1.6414E? 1 1.000 $\begin{array}{lllll}33914 \quad 293 \quad 3 & 8.390 & 0.000\end{array}$ $\begin{array}{lllllll}0.0 & 1.0480 \mathrm{E} \cdot 2 & 1 & 1.0079 & 1.028 \mathrm{BE} 2\end{array}$ $1 \quad 15.99949 .340100 \quad 1 \quad 1.000$

cid geom

read mixt mix=1 23901 6.1468-5 8016 3.3387-2 1001 6.6774-2 mix $=280163.34558-210016.69116-25 c 5=1$ end mixt

end data

Input File for "Pu with a Thin Steel Shell and Full Water Reflecrion as given in Table 5.

mitawl

05

iss $\quad 19 \quad 9^{2} 15^{3} \quad 2^{4} \quad 18$

$$
\begin{array}{lllllll}
500 & 0^{12} & 0 & 0 & 0 \\
0 & 0 & & & 0 & & 0
\end{array}
$$

iss $\quad 8016 \quad 7014 \quad 1001$

$24000 \quad 28000 \quad 26000 \quad-26001$

$\begin{array}{lllll}94358 & 94239 & 94240 & 94241 & 94242\end{array}$

3** $\quad 94239 \quad 299.8 \quad 3 \quad 17.7800 \quad 0.0000$

$0.06 .6004 \mathrm{E}-05$ i $1.00792 .0092 \mathrm{E}-0$

$115.8772 \quad 2.0505 \mathrm{E}+03 \quad 1 \quad 1.000$

$\begin{array}{llllll}26001 & 299.8 & 3 & 17.9070 & 0.000\end{array}$

$\begin{array}{lllll}0.0 & 0.0618 \quad 53.69 & 2.312\end{array}$

40299.8

$151.9960 \quad 1.1596 \mathrm{E}-60,1.020$

the

renos.

ISEXCHALARK \& SPHKRE WTTH STEEL SEELL ALD WATER REFL ECTOR

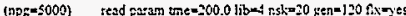

fdn-yes nubyes ip 5 - 5000 tba-60.0 end param

jead geomeing sphere 1117.78

sphete 2 I 17.907

sphere 3126000 cubsid $0 ! 6 P \div 5.100$

end geom

read mixt mix-1 942396.6004-5942:0 3.5692-7

$70147.5114-480163 . \$ 514-210016.5006-3260001.5457-6$

mix $=226001$ 6.175E.3 24000 $1.658-2280008.1 \leq \$ .3$

mix $=380163.332 .210016 .663-2$ seinl end mixt

end data

end

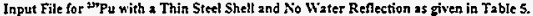

$\begin{array}{lllll}\text { OSS } & 82 & 2 & 3 & 4\end{array}$

iss

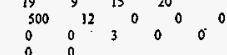

25S $8016 \quad 7014 \quad 100 \mathrm{l} \quad 26000 \quad-2600$

2400023000

$\begin{array}{lllll}94258 & 94239 & 94240 & 94241 & 94242\end{array}$

$\begin{array}{lllllllll}30 . & 94239 & 299.8 & 3 & 19.3180 & 0.0000\end{array}$

$0.08 .2232 \mathrm{E}-05 \quad 1 \quad 1.00791 .6254 \mathrm{E}+04$

I $15.8987 \mathrm{~J} .6340 \mathrm{E}-03$ \& 1.000

$94240 \quad 399.8 \quad 3 \quad 193180 \quad 0.0000$

$0.03 .9321 \mathrm{E}-06 \quad 1 \quad 1.00793 .3992 \mathrm{E}+05$

$16.00033 .4396 \mathrm{E}-0.4 \quad 1 \quad 1.000$

$26001 \quad 299.8 \quad 3 \quad 19.4400 \quad 0.0000$

$0.06 .3510 E-02 \quad 1 \quad 58.691 .7995 E+00$

$4 * * 1299.8$

$151.9960+1234 E+00$ \& 1.000

-kenos

PU BEXCHMARK 4 SPHERE WTTH STEEL REFIECTOR (APL5000)

read prom tme $=2000$ libet ask $=20 \mathrm{gen}=120 \mathrm{gx}-\mathrm{yes}$

ten-yes np5-5000 nub-yes tbz- 60.0 end param

read geomery sphere i1 19.318

sphere 2119.4

enoid 016 PI9.s

end geom

read mixt mix $+19423982332.5943403 .9521-6942413.6356-7$

$943435.3567-970146.4132-480163.4536-210016.5520-2 \quad 260006.965-7$

mixm2 26001 6.551E.2 24000 1.654-2 28000 6.51-3 sct-1 end mixt

end dats

end

Input File for "Pu with a thin Steel Shell plus a 4" Concrete Shell as given in Table 5 anitatit

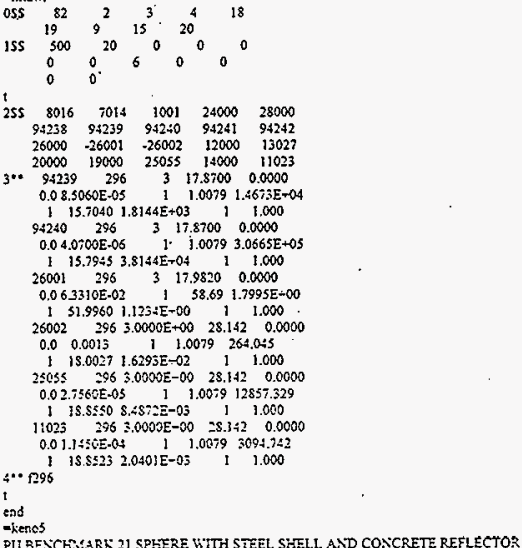


HNF-SD-TP-SEP-063, Rev. 0

NCS Basis Memo 96.2

December 30, 1996

Page 40

$(5000)$

read param one $=200.0$ tibed nsk-20 genm 120 fix-zes

foryes npo 5000 nubryes tha $=60,0$ end parm

read geometry sphete 1117.87

sphere. 2117.982

sphete 3128.142

cuboid of 6 P28.2

end feom

read mist

$\operatorname{mix}=1942398.506-5942404.070-69.42412 .7 .7$

$942426.0-970142.098 .380163 .601-210016.118-2260007.3 .7$

STEEL VESSEL ISOTOPICS

mix $=226001$ 6.33]E-2 24000 1.654-2 28000 6.51-3

CONCRETE ISOTOPICS

mix=3 $120007.62-4130273.353-3 \quad 200002.609-326002$ !.342-3

$190004.358+250552.756 .5140001 .293-210011.737 .2$

$110231.145-180164.529 \cdot 2$ scl-1 end mixt

end cala

end

Input File for "Pu with a 4" Concrete Shell as given in Table 5. -7itawi

$$
\begin{aligned}
& \begin{array}{llllll}
\text { OSS } & 82 & { }^{2} & 9^{3} & 5^{4} & 18
\end{array}
\end{aligned}
$$

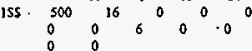

$$
\begin{aligned}
& \text { t. } \\
& \begin{array}{llllll}
255 & 8016 & 7014 & 1001 & 94239 & 94240
\end{array} \\
& \begin{array}{lllll}
26000 & -26001 & 12000 & 13027 & 20000
\end{array} \\
& 19000 \quad 25055 \quad 14000 \quad 11023 \quad 24000 \\
& 28000 \\
& \begin{array}{llllll}
50 * & 94239 & 298 & 3 & 17.7800 & 0.0000
\end{array} \\
& 0.07 .8828 \mathrm{E}-05 \quad 1 \quad 1.00791 .6419 \mathrm{E}-04 \\
& \text { I } 15.8238 \quad 1.7975 \mathrm{E}+03 \text { I } 1.000 \\
& \begin{array}{lllll}
94240 \quad 298 & 3 & 17.7800 & 0.0000
\end{array} \\
& 0.03 .7851 \mathrm{E}-06 \quad 1 \quad 1.00793 .4195 \mathrm{E}+0 \mathrm{~S} \\
& 115.91573 .7659 \mathrm{E}+04.11 .000 \\
& 26000 \quad 298 \quad 3 \quad 17.89176 \quad 0.0000 \\
& 0.06 .3310 \mathrm{E}-02 \quad 1 \quad 58.69 \quad 1.799 \\
& \text { I } \$ 1.9960+.1234 E+00,1.000 \\
& \begin{array}{lllll}
26001^{\circ} & 298 & 3 & 28.05176 & 0.0000
\end{array} \\
& 0.01 .3419 \mathrm{E}-03 \quad 1 \quad 1.00792 .6444 E+02 \\
& \begin{array}{llll}
17.6042 & 1.5657 \mathrm{E}-02 & -1 & 1.000
\end{array} \\
& \begin{array}{lllll}
25055 & 298 & 3 & 28.05176 & 0.0000
\end{array} \\
& 0.02 .7673 \mathrm{E}-05 \quad 1 \quad 1.00791 .2821 \mathrm{E}-04 \\
& 118.48108 .1422 \mathrm{E}+03 \quad 1 \quad 1.000 \\
& \begin{array}{lllll}
11023 & 298 & 3 & 28.05176 & 0.0000
\end{array} \\
& 0.01 .1417 \mathrm{E}-04,100783.1077 \mathrm{E}+03 \\
& 4^{4 *}+298 \\
& 1 \text { 18.4778 } 1.9708 \mathrm{E}+03,1.000
\end{aligned}
$$

PU SPHERE WTTH STEEL SHELL AND 4" CONCRETE REFLECTOR (nPS-5000)

read param tne -200.0 lib $=4$ nsk $=20$ ba $=60.0$ geri $=120$ flx $=$ yes

fth-yes plimes nub-yes nus-yes nps -5000 end parars

read geometry sphere II I 17.78

sphere 2117.8918

sphere 3128.05

cuboid 016 P28.1

end geors

read mix

PU 1SOTOPICS

mix-1 $942397.883-5$

$942403.785-6$

$70141.146-3$

80163.516 .2

10016.345 .3

STEEL VESSEL, ISOTOPICS

$\operatorname{mix}=2260008.351 \mathrm{E} \cdot 2$

$240001.654-2$

250096.51 .3

CONCRETE ISOTOPICS

$\operatorname{mix}=5$

120007.619

$130273.353-3$

20000 2.609.3

25001 1 342.3

190034.3574

$250552.767-5$

J $20001.29: .2$

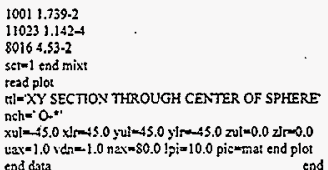

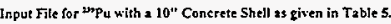

Titzw]

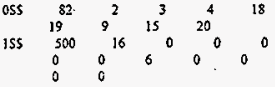

$$
\begin{aligned}
& \begin{array}{llllll}
255 & 8016 & 7014 & 1001 & 94239 & 94240
\end{array} \\
& \begin{array}{lllll}
26000 & -26001 & 12000 & j 5027 & 20000
\end{array} \\
& \begin{array}{lllll}
19000 & 25055 & 14000 & 11023 & 28000
\end{array} \\
& 24000 \\
& \text { f.e. } \begin{array}{rrrrr}
94359 & 298 & 3 & 17.7800 & 0.0000
\end{array} \\
& 0.07 .1137 \mathrm{E}-05 \text { I } 1.0079 \quad 1.7945 \mathrm{E}+04 \\
& 1 \quad 15.8213 \quad 1.9691 E-03 \quad 1 \quad 1.000 \\
& 94 \geq 40 \quad 293 \quad 3 \quad 17.7800 \cdots 0.0000 \\
& 0.03,4158 \mathrm{E}-06 \text { I } 1.0079 \quad 3.7373 \mathrm{E}+05 \\
& 1 \quad 15.9052 \text { 4.1235E+04 } 111.000 \\
& \begin{array}{lllll}
26000 & 298 & 3 & 17.89176 & 0.0000
\end{array} \\
& \begin{array}{llllll}
0.0 & 6.3310 \mathrm{E} .02 & 1 & 58.69 & 1.7995 \mathrm{E}+00
\end{array} \\
& 151.99601 .1234 \mathrm{E}-00 \quad \text { I } 1.000 \\
& \begin{array}{lllll}
26001 & 298 & 3 & 43.29176 & 0.0000
\end{array}
\end{aligned}
$$

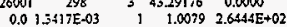

$$
\begin{aligned}
& \begin{array}{lllll}
17.6042 & 1.5657 \mathrm{E}+02 & 1 & 1.000
\end{array} \\
& \begin{array}{lllll}
25055 & 298 & 3 & 43.29176 & 0.0000
\end{array} \\
& \begin{array}{llll}
0.02 .7673 \mathrm{E}-05 & 1 & 1.0079 & 1.2821 E+04
\end{array} \\
& 1 \quad 18.48108 .1422 \mathrm{E}-03 \quad 1 \quad 1.000 \\
& \begin{array}{lllll}
11023 & 298 & 3 & 43.29176 & 0.0000
\end{array} \\
& \begin{array}{ccccc}
0.0 & 1.1417 \mathrm{E}-04 & 1 & 1.0079 & 3.1077 \mathrm{E}+03 \\
1 & 18.4778 & 1.9703 \mathrm{E}+03 & 1 & 1.000
\end{array} \\
& \text { 4"0 } 298
\end{aligned}
$$

$t$

-kenos

PU SPHERE WTTH STEEL SHELL AND 10- CONCRETE REFIECTOR (nPG-5000)

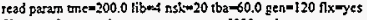

fdin-yes plin-yas nub-yes na-yes npg-5000 end param

read geometry spheze $1 / 17.78$

sphere 2) 17.8918

sphete 3145.29

cuboid 016944.0

cnd geom

PU ISOTOPiCS

mix $1942397.114-5$

$942403.416-6$

$70 \div 4+1.146+3$

$80163.473-2$

30016.258 .2

STEEL VESSEL ISOTOPICS

mix $-2260006.331 \mathrm{E}-2$

$240001.654-2$

$2800006.51-3$

CONCRETE ISOTOPICS

mix $=5$

$120007.619-4$

$130 \geq 73.353 .3$

$200002.609+3$

$260011.342-3$

$190004.357-9$

$250552.267+5$

$140001.29 \div 2$

10011.739 .2

$110231.112-4$

$80164.53-2$

sti-1 end mixt

resd plot

thl-XY SECTION THROLGH CENTER OF SPHERE

$x=0.0$

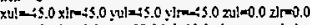

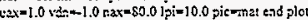




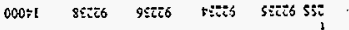

$\begin{array}{lllll}0 & 0 & 9 & 0 & 0 \\ 0 & 0 & 0 & 0\end{array}$

$\begin{array}{llllll}0 & 0 & 0 & 41 & 00 s & 5 s 1\end{array}$

\$1 6 of 61

$81+\leqslant z$ as 550

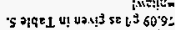

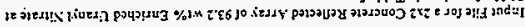

$$
\begin{aligned}
& \text { 3:ep p=s } \\
& \text { 2:2p pas }
\end{aligned}
$$

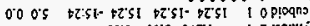
000 Do's OLTI I z ISpethis 000 co's opicl i i sopeifís

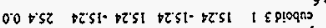

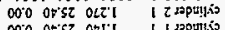

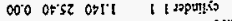

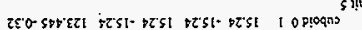

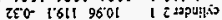

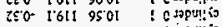
zeo sict $950 \mathrm{OL}$ i i isputiois z50. 000 9501 1 z zapuiks

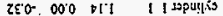

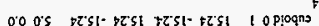

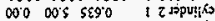

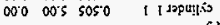

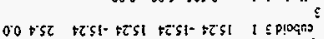

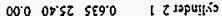

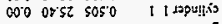

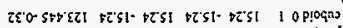

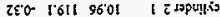

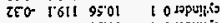

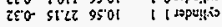

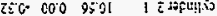

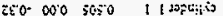

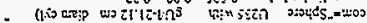

woss pess

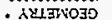

..................

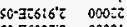

50-36052's 00091

$50-3 \$ 366^{\circ} 1 \quad 5100$

$50-36 \$ 20 \%$

$20.369 \div 6 \quad 9108$

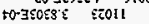

$20.310+0.11001$

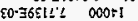

$50.79168+00061$

$0038625 \tau \quad 0009 \pi$

E0-35:120.8 00002

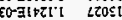

to-3s\$81.

ipracios.

20-36986's Lzosi

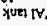

$\sum=x ! 4$.

$20-39515 \% 1001$

2003615,8102

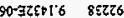

$60-3565 t \div \quad 9 \& 2 Z 6$

to-31909: sezzo

90-3ะ69l: t?

tons

- 5sषrixin

גхич pezs.

vered pus

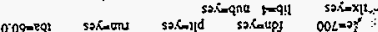

$002=3:$

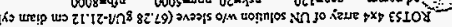
exolis:

0001 I $20+3609658658 \% 91$

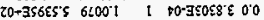
00000 000\%'st it $\varepsilon 6 z$ czo!

0001 I $70+75966^{\circ} 8 \quad 667 L^{\circ} 91$ ! $20+365658$ 6LC0. I 00000 000\%'sz i E6z 00092

0001 i t $00-920501$ LISI' 91 ।

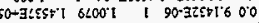
205600095012 z $56 z 85 z z 6$

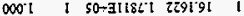

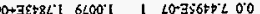
20560 0095 or $z \leqslant 6 z \quad 9 \leqslant 266$

0007 i $20-35+1, s+10.51$ i $\varepsilon 0+3852 \pi$ s $6600 \mathrm{t}$ i $50-31909^{-1} 00$ $z 056^{\circ} 0$ coss ot $\tau \varepsilon 6 \tau 5 s i z 6$

0001 i $100-35865 \% 2609191$ i 50 -35t15: 65001 I $90-3569 L^{\prime} 100$

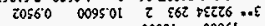

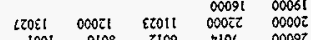
1001 9108 zा09 b106 00092 coost sezz6 9:2z6 5\$zZ6 sszzs ssz

00

$\begin{array}{lllll}0 & 0 & 9 & 0 & 0\end{array}$

$\begin{array}{llllllll}0 & 0 & 0 & \text { ll } & 005 & 551\end{array}$ Si 6 ot 61

81 \& $\tau$ ts 550

S गमाप

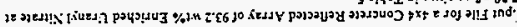

pus

exep pus - 
HNF-SD-TP-SEP-063, Rev. 0

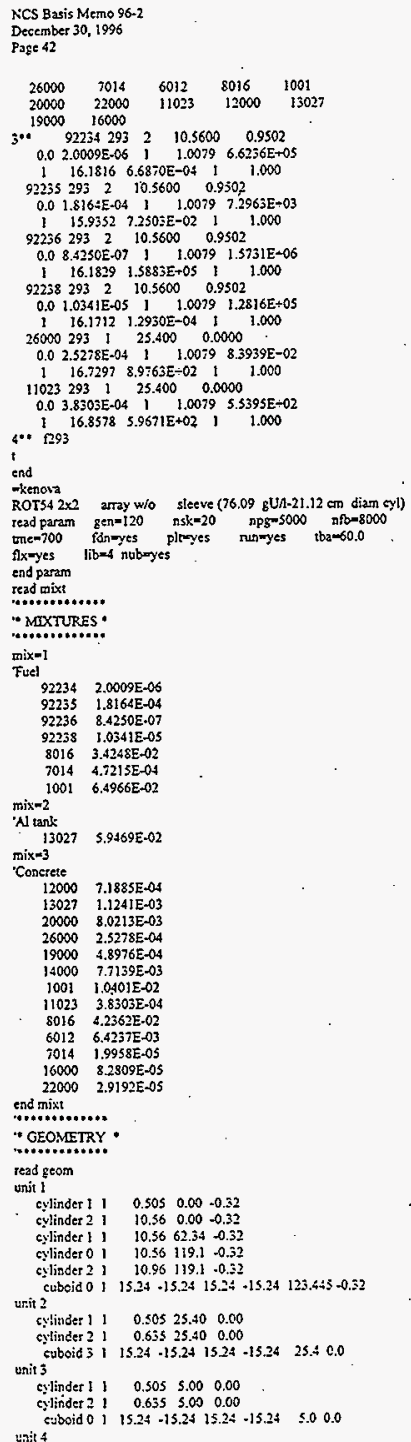




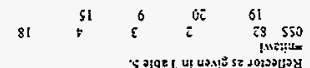

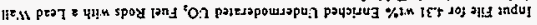

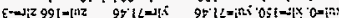

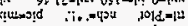
10id prat

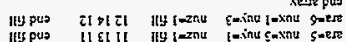

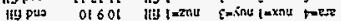
119 pus $t L L L$ 4681 $1 \div 8$

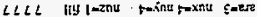

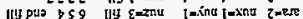
III pus i c Scute pest

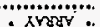
n...................

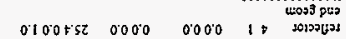

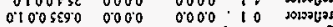
000000 g-iest s! p!um [egols 0.00000 2-ient $0.0000,0$ taitire $\quad$ cl juen

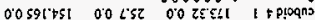

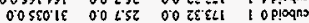

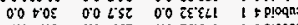

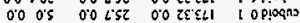

$00591+5 t$ 0.0zzt 00 ist $1+$ ploqno

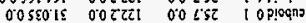

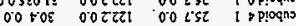

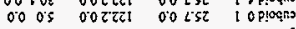

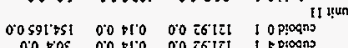

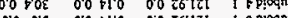

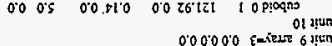

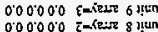
0.00000 Imíriz 6 jujan

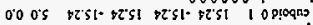

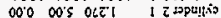
000 oos ort 1 is apultio 9 ỵun

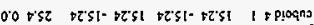

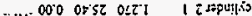

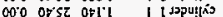

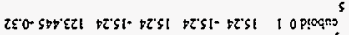

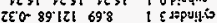

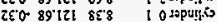
zEO I.611 858 i 2 sepunisio

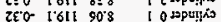

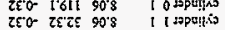

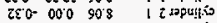

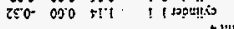

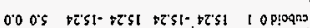
000 0OS 5890 i a jopuriós

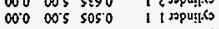

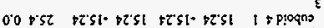
000 ot'sz 5E9. 1 i jeputs 00.0 0. $5 \bar{c} 505 \%$

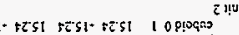

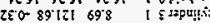

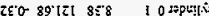

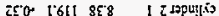
tE. l'611 90'\$ 10 now ZEO ZEZE 908 I I 19ptifis

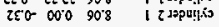

$50-0005050 \quad 1120 \%$ سx:

- NIIJNOzD.

1Xitug

s0-30615: 2005:

So-360ses 00091

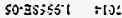

SO-E:E's हle?

zo-3igitit glos

10-350s8

20-310501 1001

$50-36 \leq 1 \leq 20002$

$50.3 \% 68500061$

$50.38 \div 252 \quad 00092$

so-asticos 0000 c

50.3inzL $\angle z 0 E$

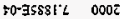

sistsoos.

$90.3 \$ 9 \$ 68 \quad 00075$

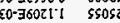

50-37328 00091

50.305S8 5 I

co-assift 00051

50-zisze z $z 100$

$80.300 t 5 \div-0008 z$

20-358691 00052

$20-32586510092$

गजग्गS [ग्स,

$20.769565 \quad \angle 20 S 1$ भife $\bar{c}=\mathrm{x}$

z0-5\$908's 1001

$\$ 0-311617 \geqslant 104$

zo-J58LL $910 \mathrm{~L}$

50-35:68't 8E2 6

$90-32066596266$

to-3:209's sez26

$90-319656$ t5226 गं

a.c..............

- 5ระRIXTK .

an..........

ured pro

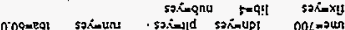

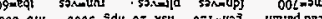

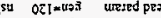

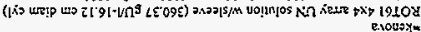

penosy

565)

$00011 \quad 1 \quad 20.95660^{\circ}+2611.85$ i $10-32650.65855$ i 50.30005 .200 00000 00tร $0 \quad 1 \leqslant 5 z 00082$

0001 I zo-31295? c085'55 I

10-31410, L 00000 00l50 i EST 000ڤZ 000 i I 60-37680.9 LOS'5S 1 80-360Z1T 0.0

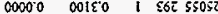

$000^{\circ} 1$ i $20.35660^{\circ} \%$. $261 \mathrm{t}^{\circ} 85^{\circ}$ i

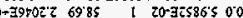
$00000^{\circ} 00150$ I 562 I0092 $000^{\prime} t$ i zo-71L96's 8LS891 ।

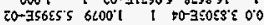
00000 0007\$2 it $\$ 62 \varepsilon 2011$ $0001 \quad 1$ 20+759L6.8 $\angle 6 \overrightarrow{0}: 91$ I $20-365658$ 6i00 1 + +0.39125200 $00000 \quad 000 \div 52$ I $\leqslant 620009 \%$ 0001 I so-365Lt? E29991 । $50-3581726100^{\circ} 1$ I $50-75268^{\circ} \circ 0^{\circ}$ $9 L 599^{\circ} 0$ 0055' $t$ s6t $8 \$ 276$

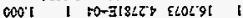
$50+358966$ t $61000^{\circ} 1$ i $90^{\circ} 92066^{\circ} \varepsilon 0^{\prime} 0$

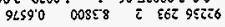

$$
\begin{aligned}
& \text { - ct osed }
\end{aligned}
$$

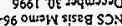


NCS Basis Memo 96-2

December 30, 1996

Page 44

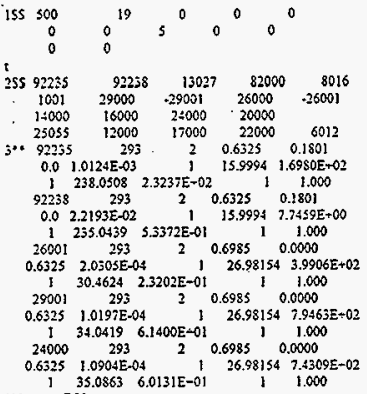

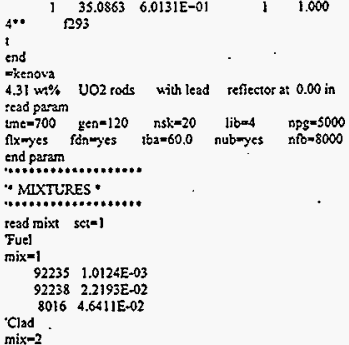

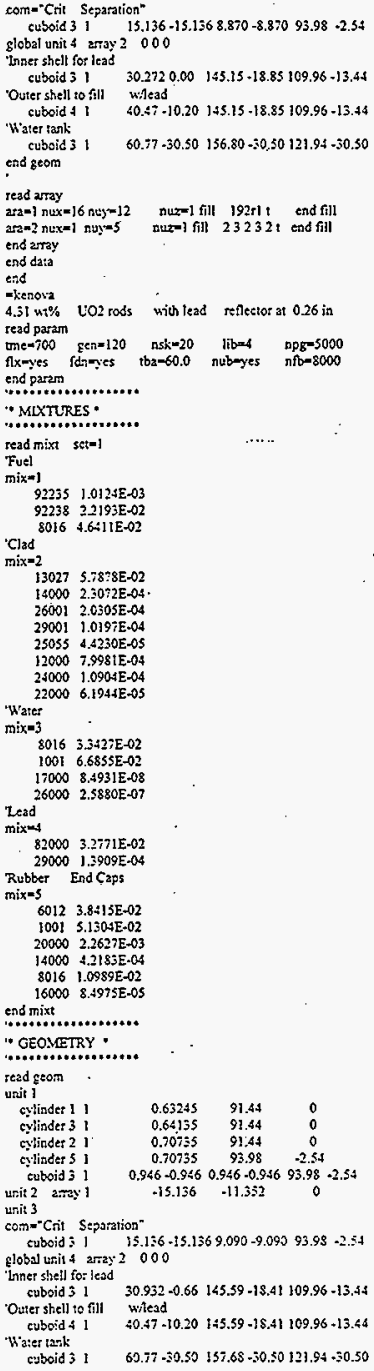


HNF-SD-TP-SEP-063, Rev. 0

NCS Basis $\mathrm{M}$ eno $\$ 6.2$

December 30, 1996

Poge 45

- end geom

atd 350 y

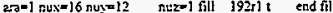

$z: 3=2 \mathrm{ntx} x=1 \mathrm{n} i \mathrm{y}=5$ nur=l fill 232321 end fill

and 2 may

end dato

end

4,31 ut\% vo2 rods with lead fentector at 0.77 in

read param

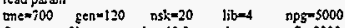

Ax $x$ yes for-yes tba $=60.0$ nub-yes nob- $\$ 000$

end param

- MLTTRES

i.....................

read mixt scu=1

Futel

mix"

$92235 \quad 1.0124 E-03$

92238 2.2193E-02

'Clad 8016. 4.6411E.02

$\operatorname{mix}=2$

$13027 \quad 5.7878 E-02$

14000 2.3072E-04

$260012.0505 E-04$

29001 1.0197E-04

25055 4.4230E-05

$120007.9981 \mathrm{E}-0$

24000 1.0904E.04

$22000 \quad 6.1944 E-05$

'Water

mix $=$

$8016 \quad 3.3272 E-02$

$1001 \quad 6.6855 \mathrm{E}-02$

17000 8.4931E-08

$26000 \quad 2.5 \$ 80 \mathrm{E}-07$

tead

$82000 \quad 3.2771 E-02$

$29000 \quad 1.3909 \mathrm{E}-0.4$

'Rubber End Caps

$\operatorname{mix} 5$

$6012 \quad 3.8415 \mathrm{E}-02$.

1001 S.1304E-02

$200002.2627 \mathrm{E} .03$

$14000 \quad 4.2$ I S3E-04

$8016 \quad 10989 E .02$

16000 8.4975E-0S

end mixt

* GEOIETRY •

read feom

unit i

cylinder 3

cylinder 5

auboid 3 ?

unit 2 array

unit 3

com="Crit Separation"

eubois $31 \quad 15.136-15.1368 .715-8.71593 .98$-2.54 flobal unit 4 amay 2000

Tnner shel! for lead

cutroid $3 \mathrm{I} \quad 32.228 \cdot 1.95144 .84-19.36109 .96-13.44$

Outer shicll to fitl wilead

cuboid a $1 \quad 40.47-10.20 \quad 144.84-19.16109 .96-13.44$

Wiate tork

cukcis j J $\quad 60.77 \cdot 30.50 \quad 356.18 \cdot 30.50121 .94 \cdot 50.50$

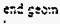

:30่ 3 aray

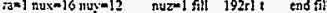

ara $=2 \mathrm{nux}=1$ nux:=5 nuzz=1 fill $23232 t$ end fill

cad atsy

cod dis:

and

-riterova

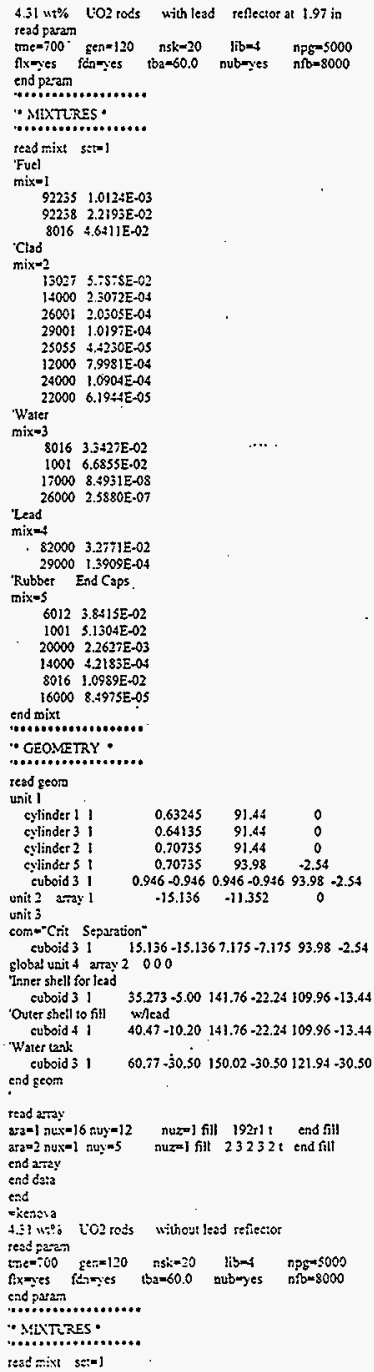


NCS Basis Meno 96-2 December 30, 1996

Page 46

Fuel

$922351.0124 E-05$

92238 2.2193E-02

Clad 8016 4.6111E-02

$\operatorname{mix}=2$

$15027 \quad 5.7878 \mathrm{E}-02$

$14000 \quad 2.3072 \mathrm{E}-04$

$260012.0505 \mathrm{E}+04$

29001 1.019;E-04

25055 4.4230E-05

$12000 \quad 7.9981 \mathrm{E}-04$

$24000 \quad 1.0904 \mathrm{E}-04$

22000 6.1944E-05

Water

$\operatorname{mix}=3$

$8016 \quad 3.342 ? \mathrm{E}-02$

1001 6.6855E.02

$17000 \quad 8.493] \mathrm{E}-08$

$26000 \quad 2.5880 \mathrm{E}-07$

Lead

mix $=$

$82000 \quad 3.2771 \mathrm{E}-02$

$29000 \quad 1.3909 E-04$

Rubber End Cags

mix $=5$

6012 3.\$415E.02

$10015.1304 E-02$

$20000 \quad 2.2627 E-03$

$14000 \quad 4.2183 E-04$

$8016 \quad 1.0989 \mathrm{E}-02$

16000 8.4975E.05

end mixt

- GEOMETRY *

.....................

reas geom

unit !

cylinder 1

Ylinder I

cylinder 2

cylinder 51

cuboid 3 ।

tnit 2 array 1

unit 3

com-"Crit Segaration"

cuboid $31 \quad$ 15.136-15.136 6.485-6.485 $93.98-2.54$

clobal unit 4 array 2000

Water tank

cuboid $31 \quad 60.77+30.50147 .26-30.50121 .94-30.50$

end geom

read array

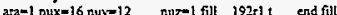

ara $=2$ nux $=1$ nuy $=5 \quad$ nuz=1 fill $23232 t$ end fill

end array

end

Input File for 4.31 wt\% Enriched $\mathrm{O}_{\text {primum }}$ MLoderated UO $_{2}$ Fuel Rods with a Leed Will Reflector as given in Table 5 .

ritzul

OSS 82

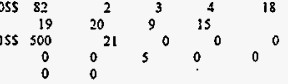

$25592235 \quad 92258 \quad 15027 \quad 82000 \quad 8016$

$1001 \div 9000-29001 \quad 36000 \quad \approx 5001$

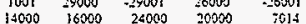

$\begin{array}{lllll}25055 & 12000 \quad 17000 \quad 20000 & 6012\end{array}$

5.. $\begin{array}{lllll}49255 & 293 & 2 & 0.5395 & 0.6409\end{array}$

$0.01 .0124 \mathrm{E}-03$ i $15.9994 \quad 1.6956 \mathrm{E}-02$

$\begin{array}{llll}1 & 258.0508 \quad 2.3237 E-02 & \text { I } 1.000\end{array}$

$\begin{array}{lllll}92235 & 293 & 2 & 0.6323 & 0.0409\end{array}$

$\begin{array}{llll}0.02 .2193 \mathrm{E}-02 \quad 1 & 15.9994 & 7.2 .4595-00\end{array}$

$\begin{array}{ccccc}1 & 235.0459 & 5.3572 \mathrm{E}-01 & 1 & 1.000 \\ 26001 & 295 & 2 & 0.70755 & 0.0300\end{array}$

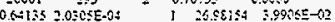

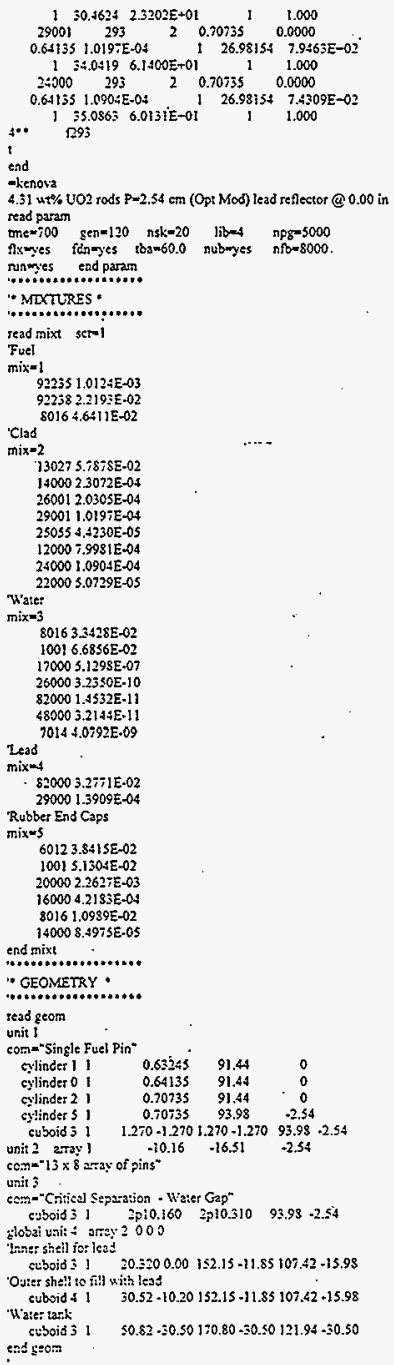


HNF-SD-TP-SEP-063, Rev. 0

NCS Basis Memo 96-2

December 30. 1996

Page 47

- read array

$n=1$ nux $=8$ puy $=13$ nuzm 1 fill $104 \pi 1 t$ end fill

a=2 nux-1 auy-s nuz-1 fill $23232 t$ end fill

end aray

end data

end

4.31 ut\% U02 rods $P=2.54 \mathrm{~cm}$ (Opt Mod) lead reflecior $(G 0.26$ is

4.31 wt\% Uo
read param

read param

$=120$ nsk $=20$ liom nps 5000

flx-yes foinmes $t b_{3}=60.0$ nubmyes $n \hat{b}=8000$

rungyes end paran

- sextrtres.

nat.................

read mixt sct-1

'Fue'

mixw

92335 $1.0124 \mathrm{E}-03$

$923 \$ 2.2193 \mathrm{E} .02$

Clad

$80164.6411 E-02$

mix=2

$130275.7878 \mathrm{E}-02$

$140002.3072 \mathrm{E}-04$

$260012,0305 E-04$

$290011.0197 \mathrm{E}-04$

25055 4.4230E-05

$120007.9981 \mathrm{E}-0$.

$24 \mathrm{COO} 1.0904 \mathrm{E}-04$

$220005.0729 \mathrm{E}+05$

Water

mix=

$80163.3428 E-02$

$10016.6856 \mathrm{E}-02$

$17000 \$ .1298 E-07$

$260003.2350 \mathrm{E}-10$

82000 1.4532E-1

48000 3.21.44E-1

7014 4.0792E-09

$820003.2771 \mathrm{E}-02$

29000 1.3909E-04

'Rubber End Caps

mix-s

$60123.8415 E-02$

$10015.1304 E-02$

$200002.2627 \mathrm{E} \cdot 03$

$160004.2133 \mathrm{E} \cdot 0 \mathrm{~S}$

$80161.0989 \mathrm{E} .02$

14000 8.4975E.0S

end mixt

- GEOMETRY

. ne.

read geom

unit 1

con-"Single Fuel Pin"

$\begin{array}{cccc}\text { cylinder 1 1 } & 0.63245 & 91.44 & 0 \\ \text { cylinder 0 1 } & 0.64135 & 91.44 & 0 \\ \text { cyinder 2 1 } & 0.70735 & 91.44 & 0 \\ \text { cylinder 5 1 } & 0.70735 & 93.98 & -2.54 \\ \text { cuboid 3 1 } & 1.270-1.270 & 1.270-1.270 & 95.98-2.54 \\ \text { unis 2 array 1 } & -10.16 & -16.51 & -2.54\end{array}$

unis 2 array 1

come-

unit 3

com-"Crilical \$eparation - Water Gap"

$\begin{array}{llll} & & & \end{array}$ flobal unit 4 artay 2000

"Inner shell for lead

cubsid 3 1. $20.980-0.66152 .31+11.69107 .42 \cdot 15.98$

Outer sitill 10 int wih less

cuboid 4 1 31.is - 10.36 152.31 -j 1.59 107.42 - 15.98

Note: tank

cuboid $31 \quad 50.82-30.50 \mathrm{i} ; 1.12 * 30.50121: 94-50.50$

cind geom

sead antay

read aray $=8$ nuy-13 00:-1 fill 104rl t end fill

F=2

snd aray end da:a

and

4.31 ut\% UO2 rods $P=2.54 \mathrm{~cm}$ (Opt Mod) lead reflectot (C) 0.52 in resd param

tne $=700$ gen 120 is $5 \mathrm{k}=20$ libe-4 npg 5000

fixmes fonces tba $=60.0$ nubores $n f 0=8000$

ningres cend param

- NIDTURES -

.e....................

readmixt set=l

Fuel

mix -1

$922351.0124 \mathrm{E}-03$

$923382,193 \mathrm{E}-02$

Clad

$0164.6411 \mathrm{E}-02$

mix $=2$

$130275.7873 \mathrm{E}-02$

$140002.50 \mathrm{~T} 2 \mathrm{E}-04$

$260012.0505 E-04$

$290011.0197 \mathrm{E}-04$

$35055+\$ 250 \mathrm{E}-05$

120007.998 IE-04

$240001.090 \div E-04$

$220005.0729 \mathrm{E}-05$

'H'ater

mix $=3$

$80165 .=428 E-02$

$10016.6856 \mathrm{E}-02$

$170005.1298 \mathrm{SE} .07$

$26000 ; .2550 \mathrm{E}-10$

$820001.4532 \mathrm{E}-11$

$480003.214 .4-11$

Zead

$70144.0792 E-09$

$820005.2771 E-02$

$2900013909 E-04$

Rubber. End Caps

mix=:

$60123.8415 E-02$

1001 5.1304E-02

$200002.2627 \mathrm{E}-03$

$160004.2183 \mathrm{E}-04$

$80161.0989 \mathrm{E}-02$

$140008.4975 E-05$

end mixt

m.

- GEONETRY -

......................

scad geom

unit ?

eom-"Sisgle Fuel Pin"

crlinder 1

cylinden 0

chinder 2

is 2 my

$\cos$

voit 3

com="Critical Separation - Water Gap"

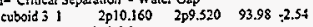
global unit 4 aray 2000

innet shell for lead

cuboid 3 । 21.641 -1.32 150.57-13.43 107.42 -15.98

'Outer sheli to fill with lead

cubcid : $1 \quad 31.84+11.52 \quad 150.57 \cdot 13.43107 .42=15.98$

Wiater isnk

cubeid $31 \leq 0.82-30.50167 .64-30.50121 .94-30.50$

cos geot

tล25 2क्ष:

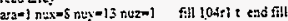

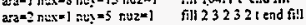

end $2 \pi x y$

and दita

end

- b:asev

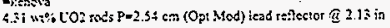


NCS Basis Merno 96.2

Deeember 30, 1996

Pege 48

\section{read param}

$n=700$ cen 120 nsk $=20$ liber npg $=5000$

fix-yes. finmyes tba $=60.0$ nub-yes nfo- 8000

rungyes end param

- MEXTURES -

1......................

read mix: sei-1

'Fue]

mix $=1$

$922351.0124 E-03$

$9225822193 E-02$

Clad $80164.6411 \mathrm{E}-02$

$\operatorname{mix}=\mathbf{2}$

13027 5.7878E-02

$140002.30 \% 3 E-04$

$260012.0505 E-04$

$290011.019-\mathrm{E}-0$.

$250554.4230 E-65$

$120007.9981 E-04$

2:000 1.0904E-04

Wore

$220005.0729 E-05$

mix=3

$80163.3428 E-02$

$10016.6856 \mathrm{E}-02$

$170005.1398 \mathrm{E}-07$

$260003.2350 \mathrm{E}-10$

$820001.4552 \mathrm{E} \cdot 11$

$480003.2144 E-11$

'Lead

$701440792 E-09$

$820003.277 \mathrm{IE}-02$

29000 I. $3909 E-04$

Rubber End Caps

mix $=5$

$60123.8415 E-02$

$10015.1304 \mathrm{E}-02$

$200002.2627 \mathrm{E}-03$

$160004.2183 \mathrm{E}-04$

$\$ 0161.0989 \mathrm{E}-02$

14000 8.4975E-0

end mixt

(n)

GEOMETRY *

read geom .

unit ?

conm"Single Fuel Pis"

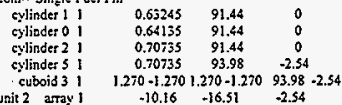

$\begin{array}{llll}\text { vait } 2 \text { aтtay } 1 & -10.16 & -16.51 & -2.54\end{array}$

comm-13 8 array of pins"

unit 3

com="Critical Separation - Water Gap" $\begin{array}{lllll} & & & \end{array}$

global unit 4 arras 2000

trinet shell for lead

cubaid 3 I $25.725-5.41141 .83-22.17107 .42 \cdot 15.98$

Ovier shell to fill with lead

cuboid 4 I $35.93+15.61191 .83 \cdot 22.17107 .42-15.98$

Water tank

cuboid 3 I $\quad 50.82-30.50150 .16 \cdot 30.50121 .94 \cdot 30.50$

end geom

read aray

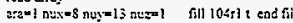

arz=2 nux-1 nuy-s nuz=l fill 23232 tand fill

cis azsy.

$\cos d a$

end

-lenova

4.31 u*: $:$ LO2 rods P-2.54 en (Opt Mod) ujthout lead reflecio reed petam

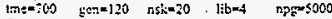

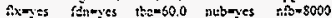

rumpes condparts.

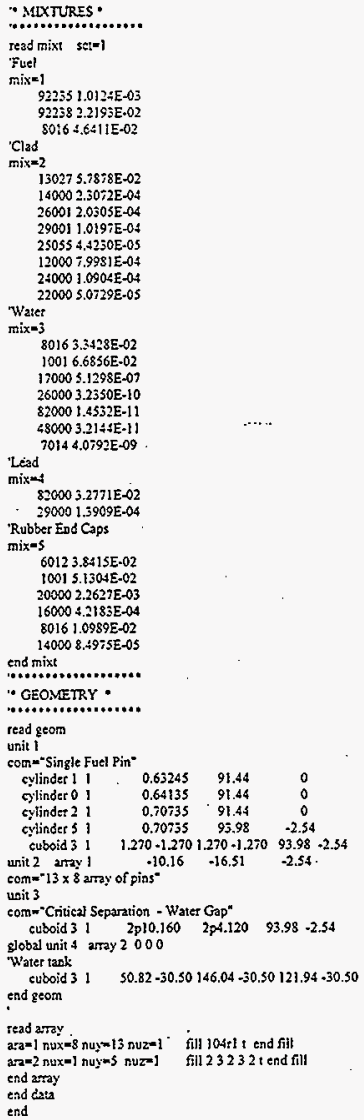

Input File for 2.35 wt\% Enriehed Cindemederated 50 , Fuel Rods with a Lead Wall Reflector as given in Table 5 .

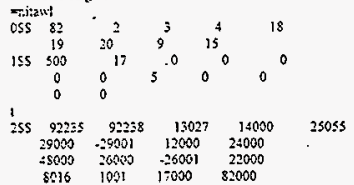


HNF-SD-TP-SEP-063, Rev. 0

NCS Basis Meno 96-2

Decembet 30.1996

Page 49

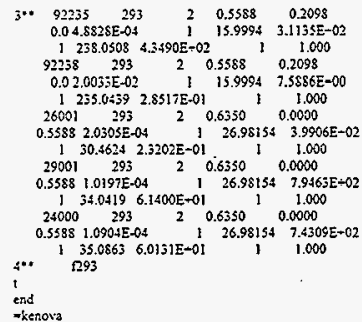


HNF-SD-TP-SEP-063, Rev. 0

NCS Basis Memo 96-2

Decenber 30. 1996

Page 5o

-kenora

2.35 wi\% UO2 Rods P 1.684 (Undemod) lead refleclor @ 1.29

read paren

Ax-yes fdn-ies nubryes libut nib-8000

end paian

read mixt sct=

Fue!

mix-1

$922354.8828 \mathrm{E}-04$

$922382.0033 \mathrm{E}-02$

$8016+1043 \mathrm{E}-02$

'Clad

mix $=2$

$130275.787 \$ E-02$

$140002.3072 E-04$

$260012.0305 E-04$

$290011.0197 \mathrm{E}-04$

$250554.4230 \mathrm{E}-05$

12000 1.9981E-04

$240001.0904 E-04$
$220005.0729 E-05$

'Wier

Wix=3

$80163.3427 E-02$

$10016.6854 E-02$

$170008.4931 \mathrm{E}-08$

$260002.58305-07$

$820001.4532 E-11$

$480005.3573 \mathrm{E}-12$

Lead

mix $=420003.2771 E-02$

$290001.3909 \mathrm{E}-0.04$

end mixt

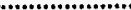

- GEOMETRY *

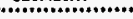

read geon

unit!.

cylinder 1 1 $0.5583 \quad 91.44 \quad 0$

A) Clad

cylinder 21 $0.635 \quad 91.44 \quad 0$

Al End Plugs

$\begin{array}{llll}\text { cylipder } 21 & 0.635 & 96.52 & -1.27\end{array}$

cuboid $31 \quad 400.842,96.52-1.27$

$\begin{array}{llll}\text { unit } 2 \text { atta: } 1 & -15.156 & +19.366 & -1.27\end{array}$

com="Center Clusger"

ynit 3 array 2

$-15.156 \quad-16.84 \quad-127$

unit 4

com="Critical Separation - Water Gap"

$\begin{array}{lll}\text { cuboid } 31 & \text { 2p15.156 2p4.250 } & 96.52 \cdot 3.27\end{array}$

global unit 5 amay 3000

"Inner shell leas'

euboid 3 i $33.588-3.28] 43.55-20.45109 .33+14.08$

Outer shell of lead

euboid 4 i $\quad 43.29-13.48143 .55-20.45109 .33 \cdot 14.08$

Water tank

cuboid $31 \quad 60.81 \cdot 30.50153 .59-50.50127 .02-30.50$

end geom

ttad aray

ara-l nux=18 nus=23 nuz=l fill $4 \mid 4 \mathrm{rl} 1 \mathrm{end}$ fit

aram2 nux $=18$ niy $=20$ nuz-1 fill $360 r 1$ t end fill

arab3 nux=1 nuy $=5$ nuz=1 fill 342431 cad till

enf $2 \pi \mathrm{xy}$

end dato

end

eimona

2.35 u*:\% LO2 Rods $P=1.68 \div$ (Cincemod) withour lead reflector

resd param

tmem 700 g $E=120$ nst $=20$ tbam60.0 ngg $=5000$

ixmes idnoyes nub-res lib $=4$ nib-8000

eid param

- Mitrias.

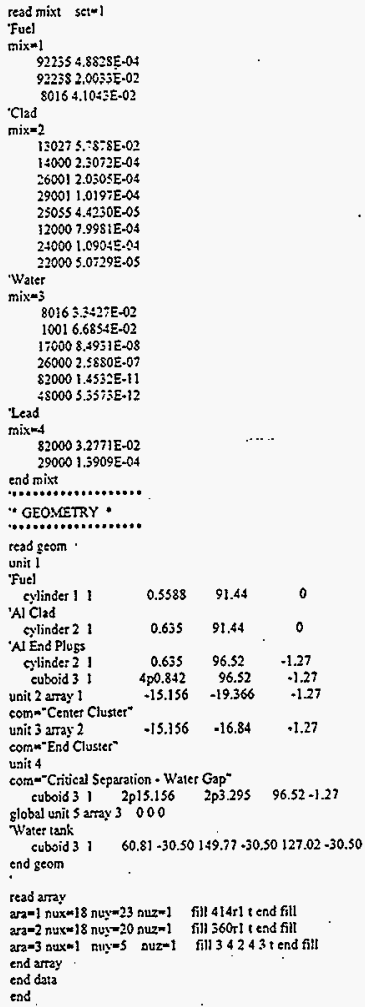

Input File for 2.35 wt\% Enciched Optimem Moderated t:O, Fuel Rods with a Lead Wall Refector as given in Table 5 .

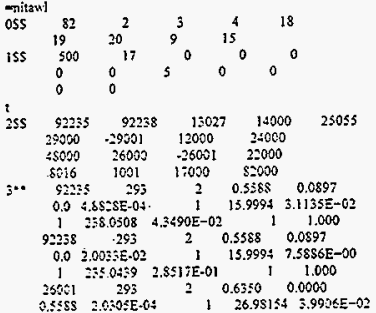


HNF-SD-TP-SEP-063, Rev. 0

NCS Basis Memo 96-2

December 30, 1996

Paye S1

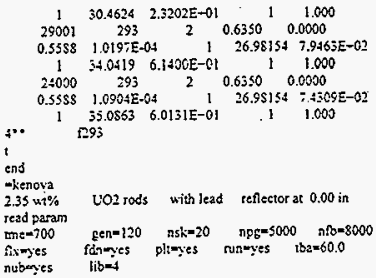

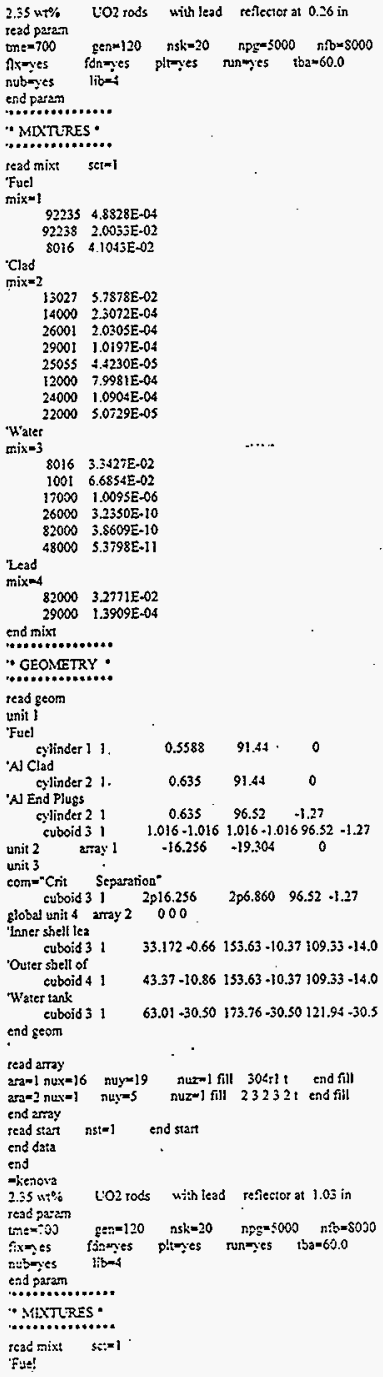


HNF-SD-TP-SEP-063, Rev. 0

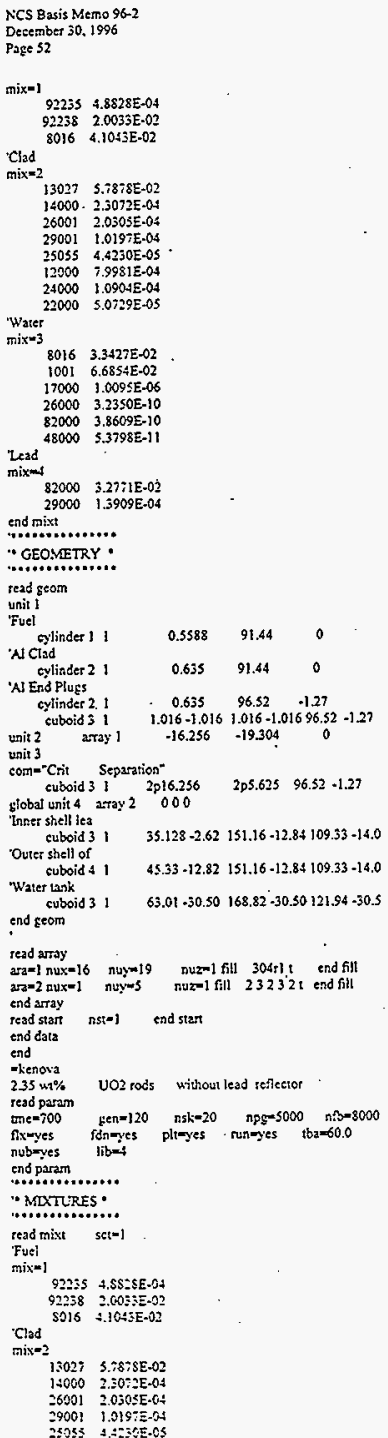

$2000 \quad 7.9981 E-04$

$24000 \quad 1.090 \div E-04$

$22000 \leq .0729 E-05$

'Wa:er

$\operatorname{mix}=\bar{j}$

$8016 \quad 3.343 .5 .03$

$100 t \quad 6.6 \$ 54 \mathrm{E}-02$

$17000 \quad 1.0095 \mathrm{SE}-06$

$26000 \quad 5.2550 \mathrm{E}-10$

$\$ 2000 \quad 3.8609 E-10$

zead

$48000 \quad 5,3798 E_{-11}$

82000 3.2771E-02

end rixs

(n)........

- GEOMETRY *

reab zeom

unit 1

Fist

cylindef 1

clad

cylinder 21

Al End Piugs

cylinder 2

wnit 2 atray !

unit 3

com-"Crit Separation"

euboid 31 2p16.256 2pt.155 96.52 -1.27

global unit 4 aray 2000

Water tarke

cuboid 3$]^{\circ} \quad 63.01-30.50162 .94 \cdot 30.50121 .94-30.5$

end geom

read $2 \pi$ y

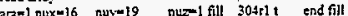

arame nux=1 nuyes nuz=l fill 232321 end fill

and amy

read start bst=1 end star

end da:a

end 


\subsection{STRUCTURAL EVALUATION}

\subsection{INTRODUCTION}

The PRTR Graphite Cask, or Radiometallurgy Cask 27, is an onsite, intra-area packaging for transporting Type $\mathrm{B}$ radioactive material within the 300 Area of the Hanford Site. This section of the document defines and evaluates the NTC structural requirements for intra-area transport of this package. Structural performance of the package is evaluated only for NTC; accident conditions are evaluated in the risk and dose consequence section of this document.

\subsection{STRUCTURAL EVALUATION OF PACKAGE}

\subsubsection{Package Structural Description}

The PRTR Graphite Cask is fundamentally a right circular cylinder of lead and stainless steel composite construction. The lead is sandwiched between outer and inner stainless steel tubular shells. At each end of the cask is a thick circular plate that is welded to both inner and outer shells, which encapsulates the lead. At the top, closure of the inner cavity is provided by a bolted blind flange with an attached shield plug of composite lead-stainless steel construction. The cask is equipped with a manually actuated, rotating, shielded drum door, which provides closure at the bottom end. None of the end closures are sealed. A handling yoke is provided on the cask and welded to the outer shell. Attached to the yoke is a lifting bail, which can be locked into position for lifting and handling of the cask. Support plates are welded to the outer bottom housing to provide support during transport.

The cask is constructed of welded 304 stainiess steel. Shielding is provided by lead, which is poured after fabrication of the stainless steel body and internal components.

\subsubsection{Chemical and Galvanic Reactions}

At the operating temperatures, no chemical or galvanic interaction of the materials will occur. The lead is encapsulated in the stainless steel; consequently, there are no agents to generate chemical or galvanic reactions. In addition, stainless steel forms a natural oxide layer, which provides protection from most corrosive agents (i.e., water) under the normal operating temperatures.

\subsubsection{Sizes of Package and Cavity}

The outside dimensions of the cask are $36.0 \mathrm{~cm}(14.0 \mathrm{in.})$ in diameter by $99.0 \mathrm{~cm}$ (39.0 in.) in length. Dimensions of the inner cavity are $7.94 \mathrm{~cm}$ ( $3.13 \mathrm{in.}$ ) in diameter by $63.5 \mathrm{~cm}(25.0 \mathrm{in}$.$) in$ length.

\subsubsection{Weight}

The PRTR Graphite Cask has an empty weight of $1,089 \mathrm{~kg}(2,400 \mathrm{lb})$ and a maximum gross weight of $1,202 \mathrm{~kg}(2,650 \mathrm{lb}\}$.

\subsubsection{Tamper- Indicating Devices}

Due to the weight of the cask closures and the intra-area shipment of this cask, no tamper indicating devices are provided. 


\subsubsection{Positive Closure}

Positive closure of the cask is provided by the bolted blind end flanges. The top end blind flange is secured with four, No. 10 hex head screws. At the bottom end the flange is closed off with a rotating shielded drum door.

\subsubsection{Lifting and Tiedown Devices}

No tiedown devices are provided on the cask. For lifting and handling, yokes on each side of the cask with a rotating bail are provided. The yokes are recessed into the outer housing and reinforced with welded plates. The bail is equipped with bearings that are pressed onto the yoke. As shown in the Part B, Section 7.5, the yoke and the lifting attachments meet the requirements of the Hanford Site Hoisting and Rigging Manual (RL 1993).

\subsection{NORMAL TRANSPORT CONDITIONS}

\subsubsection{Conditions To Be Evaluated}

Onsite structural performance of the package is assessed for Hanford Site normal conditions in this section. The onsite conditions evaluated for are hot and cold temperature extremes, reduced and increased external pressure, vibration, water spray, compression, inertial loading, and penetration. The package structural response with solar insolation is evaluated for the onsite hot ambient temperature extreme of $46^{\circ} \mathrm{C}\left(115^{\circ} \mathrm{F}\right.$ [Fadeff 1992] $)$ and without for the cold ambient temperature extreme of $-33^{\circ} \mathrm{C}\left(-27^{\circ} \mathrm{F}\right.$ [Fadeff 1992]). Reduced and increased external pressure structural response is evaluated for a Hanford Site maximum barometric pressure range of $0.94 \mathrm{~atm}$ (13.81 psi) to $1.01 \mathrm{~atm}$ (14.85 psi). Vibrational loading response of the package is evaluated for the parameters established in ANSI N14.23 (ANSI 1980). In the case of water spray, package response is evaluated for in-leakage of water at ambient temperatures and pressures. The package structural response to compression is evaluated for compressive loads resulting from anticipated stacking onto the package. Because there are no in-transient load transfers, structural response of the package to inertial loads is evaluated for rough transport of the package based on ANSI N14.23 shock loading parameters. Penetration structural response is idealized as a loading from a steel rod $3.2 \mathrm{~cm}(1.25 \mathrm{in}$.$) in diameter with a$ rounded end weighing $6.0 \mathrm{~kg}(13.0 \mathrm{lb})$ dropping onto the package from a height of $1.0 \mathrm{~m}(40.0 \mathrm{in}$.$) .$ These loads are to be applied independently and nonsequentially.

\subsubsection{Acceptance Criteria}

The criteria for acceptable performance of the package are based on all major critical components of the package remaining structurally functional, the contents remaining contained, and only superficial damage of noncritical components being incurred during NTC. To meet the criteria for NTC, the analytical tests are to assume, as a worst case, the package is intermittently subjected to the above loading conditions during normal transport operations. Performances of the package in meeting these criteria are demonstrated by either positive margins of safety based on material yield strength or package loadings that are within acceptable limits of the component/materials used in the package.

\subsubsection{Hot and Cold Evaluation}

Based on the thermal evaluation from Part B, Section 8.0, for a worst-case heat source of $5.65 \mathrm{~W}$ with solar insolation under Hanford Site conditions, the maximum internal component temperature of the cask is $79^{\circ} \mathrm{C}\left(175^{\circ} \mathrm{F}\right)$. Considering the materials of construction (lead and stainless steel), no material degradation or appreciable reduction in yield strength will occur. Under 
these conditions the external temperature of the cask is $78{ }^{\circ} \mathrm{C}\left(172{ }^{\circ} \mathrm{F}\right)$. Consequently, structural performance of the package is not affected by the Hanford Site hot temperature extreme. Following the thermal analysis, the radiological payload activity was reduced, resulting in a heat loading of $2.92 \mathrm{~W}$. Because the heat loading is less than that previously analyzed, the conclusions remain the same.

Evaluation of cold temperature package performance shows that because the primary structural material of construction is stainless steel, no extremely cold weather shipping restrictions are required. Austenitic stainless steel is not susceptible to low-temperature brittle fracture. Consequently, with an onsite, low, extremely cold temperature of $-33^{\circ} \mathrm{C}\left(-27^{\circ} \mathrm{F}\right)$, no degradation cask of performance will occur.

\subsubsection{Reduced and Increased External Pressure}

Because the cask is not sealed, reduced or increased external pressure is not a concern.

\subsubsection{Vibration}

Vibration of the package is not a concern because the shipment occurs only 12 times a year for a distance of less than $1.61 \mathrm{~km}(1.0 \mathrm{mi})$. Based on a speed of $24 \mathrm{~km} / \mathrm{h}(15 \mathrm{mi} / \mathrm{h})$ for a distance of $1.61 \mathrm{~km}$ (1.0 mi), 12 times a year, at a loading frequency of $2 \mathrm{~Hz}$ (ANSI 1980), this equates to approximately 6,000 cycles per year. Relative to the loading on the materials and the material fatigue strengths, vibrational loading on this cask is not significant.

\subsubsection{Water Spray}

Because the package is not sealed, in-leakage of water into the cask cavity is a concern. Consequently, all payloads must be shipped in sealed containers. Prior to and after transport, the cask must be inspected for any in-leakage of water into the cask cavity.

\subsubsection{Compression}

The package is shipped as an exclusive-use shipment, and stacking on the package is prohibited. Consequently, package compression is not a concern.

\subsubsection{Inertial Loading}

During normal transport of this package, no in-transit load transfers are involved. Consequently, normal condition inertial loads would arise from rough transport shock loads of $3.5 \mathrm{gs}$ vertical to the plane of travel and $2.3 \mathrm{gs}$ in the direction of travel (ANSI 1980).

In the case of the rough transport, shock loads of the conveyance are evaluated as intermittent in nature and applied as a single pulse to the package. Because the duration of the shock load is of such long duration (greater than three times the natural frequency of the system), it is applied as a quasi-static load, and the package is evaluated by classical linear elastic methods. To ensure component and material loading are within the elastic range, the allowable stresses are established on the basis of the maximum shear stress theory of failure. The weld allowable loading is established on base material yield strength with a joint efficiency reduction factor based on the American Society of Mechanical Engineers Boiler and Pressure Vessel Code. Section VIII (ASME 1992). 
Evaluation of rough transport loads on the package presented in Part B, Section 7.5, shows that the package remains fully functional, maintains structural integrity, and maintains the contents. In the evaluation, package performance is analyzed for both vertical and longitudinal loadings. In both cases the evaluation shows the induced stresses on the package are below the allowable stresses.

\subsubsection{Penetration}

The evaluation presented in Part B, Section 7.5, shows the exposed surfaces of the package cannot be penetrated by a $6.0-\mathrm{kg}(13.0-\mathrm{lb})$ object dropped from $1.0 \mathrm{~m}(40.0 \mathrm{in}$.$) . Results of the$ evaluation show that only superficial marring of the exposed stainless steel surfaces results from dropping the object.

\subsubsection{Conclusions}

The results of these evaluations show the package is acceptable for transport on the Hanford Site under NTC. Due to the possibility of in-leakage of water into the cask cavity, proper protection and sealing of the payload and cask internals are required.

\subsection{REFERENCES}

ANSI, 1980, American National Standard Design Basis for Resistance to Shock and Vibration of Radioactive Material Packages Greater than One Ton in Truck Transport, DRAFT, ANSI N14.23, American National Standards institute, New York, New York.

ASME, 1992, Boiler and Pressure Vesse/ Code, Section VIII, Division 1, American Society of Mechanical Engineers, New York, New York.

Fadeff, J. G., 1992, Environmental Conditions for On-site Hazardous Materials Packages, WHC-SD-TP-RPT-004, Rev. 0, Westinghouse Hanford Company, Richland, Washington.

RL, 1993, Hanford Site Hoisting and Rigging Manual, DOE/RL-92-36, U.S. Department of Energy, Richland Operations Office, Richland, Washington. 


\subsection{APPENDIX: STRUCTURAL ANALYSIS}

ENGINEERING SAFETY EVALUATION

Subject: PRTR Cask NTC Structurai Evaluation \& Puncture Threshold

Clecker: Date: 05/19/97

Datc: $05 / 25 / 97$

l. Objective:

The objective of this evaluation is to evaluate the PRTR cask performance relative to tho Normal Transport Conditions outlined within Section 7 of this Safcty Evaluation Packaging (SEP). Also this evaluation determines adequacy of lifing system and the cquivalent stecl thickness of the cask for deternination of the puncture failure threshold.

II. Reterences:

ANSI, 1992, ANSI N14,23, Draf American National Standard Design Basis for Resistance to Shock and Vibration of Radioacive Material Packages Greater than One Ton in Truck Tramsport, American National Standard Institute, New York, New York.

ASME, 1995, Boiler and Pressure Vessel Code, Section II, Part D, Amcrican Socicty of Mechanical Engineers, Now York, New York.

Roark, R. J., 1965, Formulas for Siress and Strain, Fourth Edition, McGraw-Hill Book Company, New York, New York.

Blodgett, O. W, 1966, Design of Welded Strtchures, The James F. Lincoln Arc Welding Foundation, Cleveland, Ohio.

Roark, R. J., Young, W. C., 1983, Formulas for Strest and Strain, Fifth Edition, McGraw-Hitl Book Company, New York, Now York.

ASME, 1992, Boiler and Pressure Vessel Code, Section VIII, Division 1, American Society of Mechanical Engineers, New York, New York.

Rinchart, J. S., and Pearson, J, 1954, Behovior of Metals Under Impulsive Loads, American Socicty of Metals, Cleveland, Ohio.

ANSI, 1993, ANSI N14.6, American National Standard for Radioactive Malerials-Special lifing Devices for Shipping Containers Woighing 10000 Pounds $(4500 \mathrm{~kg})$ or More, American National Standard Institute, New York, New York.

ORNL, 1970, Cask Designer's Guide, ORNL-NISC-68, Oak Ridge National Laboratory, Oak Ridge, Tennessec.

Mathead Plus 5, 1994, User's Guide, Math Sott Inc, Cambridge, Massachusctts.

III. Resulis and Concjusions:

This cvaluation shows that the PRTR cask will meet normal cransport conditions (NTC) and lifting loads as specified in Section 7 of this SEP. 'The cvaluation shows the incrial loadings on the cask from rough transport are well below the material yield. Consequently, rough transport will not result in any permanent deformation of the package. The results demonstrate that the eask will not sustain any damage during NTC and remain fully functional.

Also, within this evaluation, the equivalent steel thickness of the package is determined. Based on empirical data (Rinchart, 1954) the cquivalent stocl thickness of the cask body is 2.6 inches. 


Subject: PRTR Cask NTC Structural Evaluation \& Puncture Threshold
Originator: S. S. Shiraga Page: 2 of 11
Checker:
R.J.Smith Date: $05 / 19 / 27$

\section{Evaluation:}

\section{Normal Transport Conditions Evaluation of PRTR Cask:}

\section{Determination of inertial loading for NTC:}

During normal transport of this package no in-transit load transfers are involved. Conseguently, normal condition incrtial loads arise from rough tranisport shock loads. Rough transport loads are derived from ANSI N14.23 (ANSI, 1980). Rough transport shock loads for this package are defined as a vertical $3.5 \mathrm{~g}$ and longitudinal (in direction of travel) $2.3 \mathrm{~g}$ shock load to the package. Lateral load of $1.6 \mathrm{~g}$ is neglected, as it is bounded by the vertical and longitudinal toads. Assume the shock is a single pulse applied to the package as a quasi-static load. Acceptance criteria is the package remain filly functional after the event, i. c., no plastic deformation of components.

Empty weight of package: $W_{p}:=2400.16 f \quad$ Maximum weight of payload: $W_{\text {pay }}:=250 \mathrm{lbf}$

Gross weight or package: $\quad W_{t}:=W_{p}+W_{\text {pay }}$

Inertial loadings: Vertical: $\quad g_{\mathrm{y}}:-\mathbf{3 . 5}$. Longitudinal: $\quad \mathrm{g}_{\mathrm{f}}: 2.3$

Matcrial parameters (ASME, 1995):

Assume cask shells are constructed of 304L, stainless steel (SA 240, Class 2) at 200 of :

Yicld strength: $\quad s_{\text {ysst }}:=21.3 \mathrm{ksi} \quad$ Poisson's Ratio: $\quad \mathrm{v}_{\text {sst }}:=0.31$

Elastic modulus: $\quad \mathrm{E}_{\text {sst }}: \because 27.610^{6} \cdot \mathrm{psi}$

Allowable stress for NTC on sst components based on maximum shear stress: $\quad s_{\text {asst }} \div \frac{2}{3}$.s ysst

Assumed cask bolts are constructed of SA193 Type B8 (Class 2) at 200 op:

Yield strength: $s_{y b}:=27.5 \mathrm{ksi}$

Allowable stress for NTC bolts based on ASME criteria: $\quad s_{a b}:=\frac{2}{3} \cdot s^{y b}$

Assume lead properties at 250 or:

$\begin{array}{lll}\text { Yield strength: } & \mathrm{s}_{\mathrm{ypb}}:=8 \mathrm{ksi} \quad \text { Poisson's ratio: } \quad v_{\mathrm{pb}}:=0.4 \\ \text { Elastic modulus: } & \mathrm{E}_{\mathrm{pb}}:=2 \cdot 10^{6} \cdot \mathrm{psi}\end{array}$


ENGINEERING SAFETY EVALUATION

Page: 3 of 11

Originator: S.S. Shiraen

Checker: R.J.Smith

Geometric parameters of package:

Idealize the package as a composite beam with of concentric cylinders of stainless steel and tead.

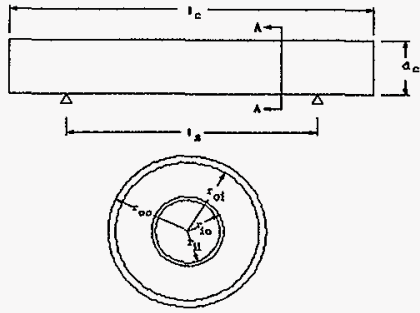

Bodtron $A-A$
Length of cask: $I_{c}:=39.625 \mathrm{in}$

Diameter of cask: $\quad d_{c}:=14$ in

Length between supports: $1_{s}:=1_{c} \cdot 2 \cdot(2.5$ in)

Outer shell wall thickness: ${ }^{t}$ os $:=0.250$ in

Outcr shell outside radius: $\quad r_{\infty}:-\frac{d}{2}$

Outer shell inside radius: $r_{\text {of }}: \because r_{00} \cdot t_{\text {os }}$

Inner shell outside radius: $\quad \mathrm{r}_{\mathrm{jo}}: \frac{3.375 \mathrm{in}}{2}$

Inner shell inside radius: $\quad \mathrm{r}_{\mathrm{ij}}: \frac{3.125 \mathrm{in}}{2}$

Inner shell wall thickness: $\quad t_{\text {is }}=r_{\text {io }}-r_{\hat{\mathrm{ii}}} \quad t_{\text {is }}=0.12^{*}$ in

End plate thickness: $\quad t_{\mathrm{ep}}:=0.5$ in $\quad$ End plate weld leg: $\quad w_{\text {leg }}:=0.1875 \mathrm{in}$

Determine deftection of lead, assuming the lead is unbonded to the stainless steel walls:

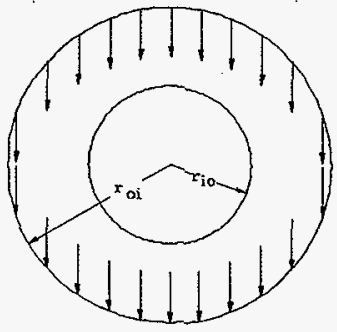

Density of lead: $\quad \rho_{\mathrm{pb}} \div 710 \frac{\mathrm{bff}}{\mathrm{ft}^{3}}$

Idealize as ring supporting it's own weight. Use Roark, 1965, case 18, page 176.

Weight per linear inch of lead:

$$
w_{p b}:=p_{p b} \cdot\left[\pi \cdot\left(r_{0 i}{ }^{2}-r_{i o}{ }^{2}\right)\right] \quad w_{p b}=55 \cdot \frac{. b f}{\text { in }}
$$

Moment of inertia of the section:

$$
\begin{aligned}
& I_{\mathrm{pb}}=\pi \cdot \frac{\mathrm{r}_{\mathrm{oi}}{ }^{4} \cdot \mathrm{r}_{\mathrm{io}}{ }^{4}}{4} \quad \mathrm{I}_{\mathrm{pb}}=1624^{\circ \mathrm{in}^{4}} \\
& \text { Nominal radius: }{ }_{\mathrm{r}_{\mathrm{pb}}}=\frac{\mathrm{r}_{\mathrm{oi}}+\mathrm{r}_{\mathrm{b}}}{2}
\end{aligned}
$$




\section{ENGINEERING SAEETY CVALUATION}

Subject: PRTR Cask NTC Structural Evaluation \& Puncture Threshold Page: 4 of I

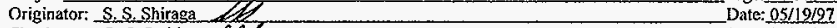

Checker: B.J.Smith \&/L D Date:05/25/97

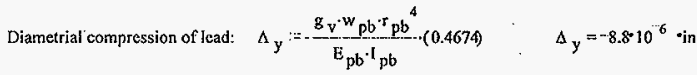

This is negligible, consequently no significant load on inner shell.

Determine Loading on Cask Body duc to Bending:

Since cask is shipped in the horizontal, setting on two support plates, idealize as simply supported beam with uniform loading which over hangs each end (Blodgett, 1966).
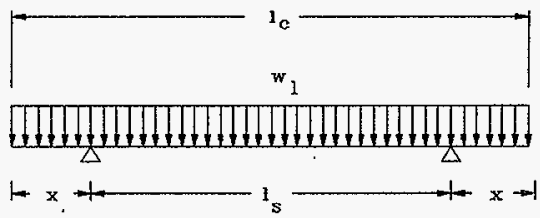

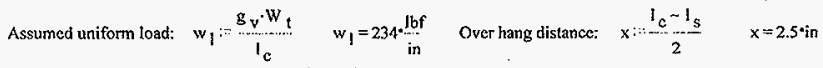

Reaction loads at supports: $\quad F_{r}: \div w r\left(\begin{array}{c}1 \\ x+\frac{s}{2}\end{array}\right) \quad F_{r}=4638 \cdot 1 b f$

Maximum moment at center: $M_{c}: \frac{w_{1}}{8}\left(I_{s}{ }^{2} \cdot 4 \cdot x^{2}\right) \quad M_{c}=34346^{\circ} l b f \cdot$ in

Moment at supports: $\quad M_{s}: \frac{w_{1} \cdot x^{2}}{2} \quad M_{s}=731 \cdot 1 b f \cdot i n$

Maximum load and moment at supports.

Determine composite moment of inertia:

Moment of inertia about center (neutral axis) of cross section:

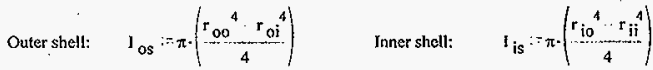


Composite moment of inertia: $\quad \mathrm{El}:: \mathrm{E}_{\mathrm{sst}} \cdot \mathrm{I} \mathrm{os}+\mathrm{E}_{\mathrm{pb}} \cdot \mathrm{I} \mathrm{pb} \cdot \mathrm{E}_{\mathrm{sst}} \cdot \mathrm{J}_{\text {is }}$

Determine composite area:

Outer shelt:

$$
\Lambda_{\mathrm{OS}}=\pi \cdot\left(\mathrm{r}_{\mathrm{OO}}{ }^{2}-\mathrm{r}_{\mathrm{oi}}{ }^{2}\right) \quad \text { Triner strell: } \quad \Lambda_{\text {is }}:=\pi \cdot\left(\mathrm{r}_{\mathrm{io}}{ }^{2}-\mathrm{r}_{\mathrm{ii}}^{2}\right)
$$

Lead shielding: $A_{p b}:=\pi \cdot\left(\mathrm{r}_{\mathrm{oi}}{ }^{2}-\mathrm{r}_{\mathrm{io}}{ }^{2}\right)$

Composite area factor: $\quad A E:=A_{o s} \cdot E_{s s t}+A_{p b} \cdot E_{p b}+A_{i s} \cdot E_{s s t}$

Bending stress in outer shell at maximum moment: $\quad \sigma_{\text {bos }} \frac{M_{s} \mathrm{~s}_{\text {stt }}{ }^{\circ}{ }_{00}}{\text { EI }} \quad \sigma_{\text {bos }}=13.67 \%$ psi

Bending stress in inner shell at maximum moment: $\quad \sigma_{\text {bis }}:-\frac{\mathrm{M}_{\mathrm{s}} \mathrm{E}_{\mathrm{Sst}} \mathrm{r}_{\text {io }}}{\text { [D] }} \quad \sigma_{\text {bis }}=3.2 \%$ psi

Bending stress in lead shielding at maximum moment: $\quad \sigma_{b p b}: \frac{M_{s} \cdot E_{p b} \cdot{ }^{\circ}}{F_{1}} \quad \sigma_{b p b}=0.95 \cdot p s i$

Maximum shear stress in outer shell: $\quad \tau_{\mathrm{sos}}: \frac{{ }^{\mathrm{F}_{\mathrm{r}}} \mathrm{E}_{\mathrm{Sst}}}{\mathrm{AE}} \quad \tau_{\mathrm{sos}}=0.21 \cdot \mathrm{ksi}$

Maximum shear stress in innor shell: $\quad \tau_{\text {sis }}: \frac{F_{r^{2}}^{E_{S S t}}}{\mathrm{AE}} \quad \tau_{\text {sis }}=0.21 \cdot \mathrm{ksi}$

Maximum shear stress in shielding: $\quad \tau_{\mathrm{pb}}: \frac{\mathrm{F}_{\mathrm{r}} \cdot \mathrm{E}_{\mathrm{pb}}}{\mathrm{AE}} \quad \tau_{\mathrm{pb}}=0.02 * \mathrm{ksi}$

Since stresses are not significant, package is demonstrated to meet acceptance critcria for verfical loading.

Determine worst case end load:

Assume as a worst case entire weight of cask is inertially loaded onto the end plate, weakest component is the weld. Also assume the platc thickness is uniform and that of the thinnest section.

Idcalize as a plate with a center hole, clamped and fixed at outer and inner edges, loaded with a uniformly distributed load (Roark, 1983, Table 24, 2h).

For determination of moments redefine: $r_{i 0}: \frac{5.5 \mathrm{in}}{2} \cdot 0.188 \mathrm{in}$

Inertial load on end plate assume uniformly distributed:

$$
w_{p l}:=\frac{g r^{w_{t}}}{\pi \cdot\left(r_{o i}{ }^{2}-r_{i o}{ }^{2}\right)} \quad w_{p l}=50^{\circ} \mathrm{psi}
$$


Plate factors:

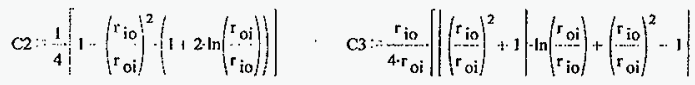

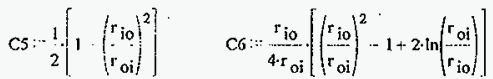

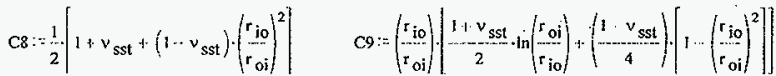

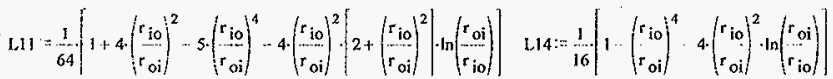

L17 $=\frac{1}{4}\left[1-\left(\begin{array}{c}1-v_{\text {sst }} \\ 4\end{array}\right) \cdot 1-\left(\begin{array}{c}r_{\text {io }} \\ r_{\text {oi }}\end{array}\right)^{4}\right]-\left(\begin{array}{c}r_{i o} \\ r_{\text {oi }}\end{array}\right)^{2} \cdot\left[1+\left(1+v_{\text {sst }}\right) \cdot \ln \left(\frac{r_{o i}}{r_{\text {io }}}\right) \mid\right]$

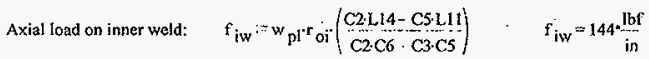

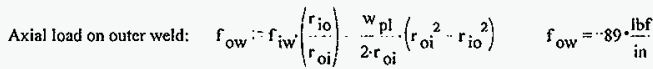

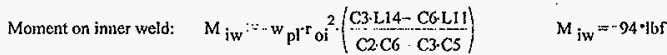

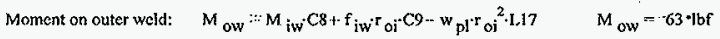

Axial load from moment on inner wcld: $f_{\text {biw }}:=\frac{\left|M_{i w}\right|}{r_{\text {io }}} \quad f_{\text {biw }}=37 \cdot \stackrel{\text { inf }}{\text { in }}$

Axial load from moment on outer weld: $f_{\text {bow }} \frac{{ }^{M} \text { ow }}{r_{\text {oi }}} \quad f_{\text {bow }}=\cdot 9 \cdot \frac{16 f}{\text { in }}$ 
ENGINEERING SAFETY EVALUATION

Subject: PRTR Cask NTC Structural Fvaluation \& Puncture Threshold

Page: 7 of 11

Originator: S. S. Shiras

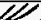

Date: $05 / 19 / 97$

Checker: R. J. Smith

Date: $05 / 25 / 97$

Total load on inner weld: $\quad f_{\text {tiw }}:=f_{i w}+f_{\text {biw }} \quad f_{\text {tiw }}=181 \cdot \frac{\text { lbf }}{\text { in }}$

Total load on outer weld: $f_{\text {tow }} \therefore\left|f_{\text {ow }}\right|+f_{\text {bow }} \quad f_{\text {tow }}=80$. inf

Determine allowable on welds:

Assuming base material strengths and ASME joint efficiency factors:

Length of inner weld:

$w_{\text {in }}:=0.1875$ in

Leg length of outer weld:

$w_{\text {out }}:=0.1875$ in

ASME joint efficiency (ASME, 1992) factor assuming no inspection:. eff: $:=0.60$

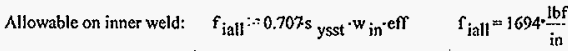

Allowable on outer weld: $f_{\text {oall }}:-0.707 s^{\prime}$ yst $w_{\text {out }}{ }^{\text {eff }} \quad f_{\text {oall }}=1694^{4}$ inf

Margin of safety on inner weld: $\quad$ MS ${ }_{i w}:=\frac{f_{\text {iall }}}{f_{\text {tiw }}}-1 \quad$ MS $_{\text {iw }}=8.38$

Margin of safety on outer weld: $\quad M S_{\text {ow }}: \frac{f_{\text {oall }}}{\left|f_{\text {tow }}\right|-1} \quad M S_{\text {ow }}=20.26$

Determine end loading of top end closure bolts:

Assume payload is restrained in cavity by dunnage and bears against the top and bottom closures. Worst case loading would occur at the top closure, since it has the fewest number of bolts. Loading results from shield plug and payload.

Weight of shield plug, ignore inner plumbing:

Plate diameter: $\mathrm{d}_{\mathrm{spl}} \therefore 8.75$ in Plate thickness: $\quad t_{\mathrm{pl}}:=0.375$ in

Shell OD: od sh $\because 5.25$ in $\quad$ Wall thickness: $t_{\text {sh }}: 0.250$ in Inther plate thickness: $t_{\text {ipl }}:=0.25$ in

Inner shell ID: $\quad \mathrm{id}_{\mathrm{ish}}=$ od $_{\text {sh }}-2-\mathrm{t}_{\text {sh }} \quad$ Length: $1_{\text {sh }} \div-5.00$ in $-\mathrm{t}_{\mathrm{ipl}}$

Lead length: $1_{\mathrm{pb}}:=1_{\mathrm{sh}} \quad$ Stainless stcel density: $\rho_{\text {sst }}:=0.29^{\mathrm{lbf}}$ 


\section{ENGINEERING SAFETY EVALUATION}

Subject: PRTR Cask NTC Sinctural Eyaluation \& Puncture Threshold

Originator: S.S. Shitaga

Page: 8 of 11

Date: 05/19/97

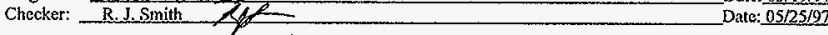

Weight of stainless stcel:

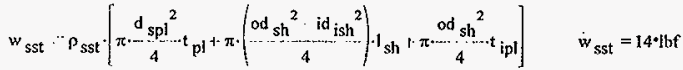

Weight of lead: $\quad w_{p b}:=p_{p b} i_{4}^{2}{ }^{2}{ }^{2}+1 p b \quad w_{p b}=11 \cdot 1 b f$

Total plug weight: $\quad w_{\text {plug }} \because w_{\text {sst }}+w_{\rho b} \quad w_{\text {plug }}=25 \cdot \mathrm{lbf}$

Assume bolts are uniformly loaded:

Nominal diameter of bolts: $d_{b} \cdots 0.25$ in Lead: $1_{b}:-\frac{20}{\text { in }}$

Tensile stress area: $\quad \dot{A}_{s}:=0.7854\left(d_{b}-\frac{0.9743}{I_{b}}\right)^{2} \quad$ Number of bolts: $\quad n$ bolt $:=4$

Assume proload torqque for bolts is: $\mathrm{T}_{\mathrm{pre}}:-30-1 \mathrm{bf}$ in $\quad \mathrm{T}_{\text {pre }}=2.5 \mathrm{ft}-1 \mathrm{bf}$

Assume nut friction factor: $\quad \mu_{n}:=0.2$

Preload force per bolt: $\quad F_{\text {pre }}: \frac{T_{\text {pre }}}{d_{b^{*} \mu_{n}}} \quad F_{\text {pre }}=600^{\circ} \mathrm{lbf}$

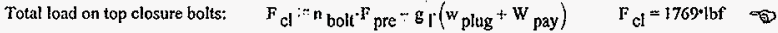

Tensile stress on bolts: $\quad \sigma_{\text {ten }}:=\frac{F_{\mathrm{el}}}{\mathrm{n}_{\text {bolt }} \mathrm{A}_{\mathrm{s}}} \quad \sigma_{\text {ten }}=13.82 \% \mathrm{ksi}$

Margin of safety: $\quad M S_{\text {bolt }}:=\frac{s_{a b}}{\sigma_{\text {ten }}}-t \quad M S_{\text {bolt }}=0.32$

Therefore $O K$, since margin of safety is positive 
HNF-SD-TP-SEP-063 DRAFT Rev. 0 May 19,1997

ENGINEERING SAFETY EVALUATION

Subject: PRTR Cask NTC Structural Evaluation \& Puncture Threshojd

Originator: S S Stiraga Date:05/19/92

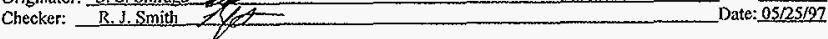

Lifting Evaluation:

Determine if the cask lifting yoke mects the 3 to 1 requirements of Hanford Hoisting \& Rigging Manual:

Idealize lifting yoke as a short beam uniformly loaded cantilever:

Length of yoke: $I_{y}:-0.9375$ in Diameter of yoke: $d_{y}:=1.5739 \mathrm{in}$

Load on yoke: $\quad F_{\text {load }}:=\frac{W_{t}}{2} \quad$ Dynamic load factor: DLF $:=1.25$

Cross sectional area: $\quad A_{y}:=\frac{d y^{2}}{4} \quad$ Moment of incrtia: $\quad I_{y}: \frac{d}{64} y^{4}$.

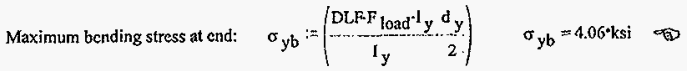

Maximum shear stress: $\quad \tau_{\max }-\frac{4 \text { DLF F load }}{3 \mathrm{~A}_{\mathrm{y}}} \tau_{\max }=1.14 * \mathrm{ksi}$

Loads are well under yield strength of material.

Determine if lifting bracket mects requitements of Hanford Hoisting \& Rigging Manual:

Cask attachment brackets at yoke:

Edge distance: $\quad d_{\text {edge }}:=3.5 \mathrm{in}-\frac{d_{y}}{2} \quad$ Side edge distances: $\quad d_{\text {side }}: \frac{4.25 \mathrm{in}-\mathrm{d}_{y}}{2}$

Bracket thickness: $t_{\text {brac }} \cdot \cdot \mathrm{I} \cdot \mathrm{in}$

Shear tear out of bracket: $\quad \sigma_{\text {bto }}:: \frac{\text { DLF.F load }}{d_{\text {side }} t_{\text {brac }}} \quad \sigma_{\text {bto }}=1.24 \cdot \mathrm{ksi}$

Tensile stress on bracket: $\quad \sigma_{\text {bten }}:=\frac{\text { DLFF load }}{2 \cdot t_{\text {brac }}-d_{\text {side }}} \quad \sigma_{\text {bten }}=0.62 \cdot \mathrm{ksi}$

Lifting bail:

Bail thickness: $t_{\text {bail }}=1 \cdot$ in $\quad$ Minimum odge distance: $d_{\min } \cdot \cdots(5.25-3.5)$-in

Assumed diameter of hook: $d_{\text {hook }}:-1$ in 


\section{GNGINERRING SAFETY EVALUATION}

Subject: PRJR Cask NTC Structural Evaluation \& Puncture Threshold

Checker: R.J.Smith

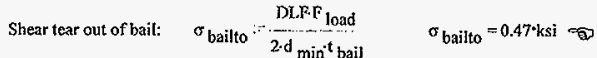

Loads are well mider yicld strength of material.

Check of bolts holding bail and cask yoke brackets together.

Nominal diameter: $d_{b}:-0.625$ in $\quad$ Lead: $\quad d_{b}:-\frac{11}{\text { in }}$. Number of bolts per leg: $n_{b}:-3$

Yield strength of PI- $18-8$ bolf (assumed same as 304 stainless steel):

Tensile stress area of screw: $A_{s}:=0.7854\left(\begin{array}{cc}d_{b} & 0.9743 \\ I_{b}\end{array}\right)^{2}$

Determine If Sufficient Thread Engagement Is Available (Industrial Press, 1992):

Available thread depth: $\quad \mathrm{E}_{\text {avail }}{ }^{\cdots}$ 1.5. in $\quad$ Number of threads per in: $\quad \mathrm{n}_{t}:^{-]_{b}}$

Minimum tensile strength of bolt: $s_{\text {bolt }}:{ }_{n_{b} \cdot A_{s}}^{D L F \cdot r}$ load $\quad s_{\text {bolt }}=2 \cdot k s i$

Maximum minor diameter of internal thread: $K_{n \max }:=0.546 \mathrm{in}$

Minimum pitch diameter of external thread: $E_{\text {smin }}: 0.5561$ in

Minimum engagement length since materials are the same:

$$
\mathrm{L}_{\mathrm{c}}:=\frac{2 \cdot \mathrm{A}^{\mathrm{s}}}{\pi \cdot \mathrm{K}_{\text {nmax }}\left[\frac{1}{2} 1 \cdot 0.57735 \mathrm{n}_{\mathrm{t}} \cdot\left(\mathrm{E}_{\mathrm{smin}} \mathrm{K}_{\mathrm{nmax}}\right)\right]} \quad \mathrm{L}_{\mathrm{e}}=0.47 \cdot \mathrm{in}
$$

Since lavail $>$ Le, rhere is sufficient thread ongagoment and bolt strengll.

N'TC Penetration of Package:

Mass of projectile: $\mathrm{m}_{\mathrm{p}}=6 \cdot \mathrm{kg} \quad$ Height of drop: $\mathrm{h}_{\mathrm{dr}}:=1 \cdot \mathrm{m}$ Hemispherical end diameter: $\mathrm{d}_{\text {hemi }} \cdot \cdot 3.2 \cdot \mathrm{cm}$ Evaluate package penetration by empirical methods ( Rhinehart and Pearson, 1954):

Velocity of projectilc:

$$
v_{0}:=\sqrt{2 \cdot g \cdot h} \mathrm{dr} \quad v_{0}=14.5 \cdot \frac{f t}{\sec }
$$


Subject: PRTR Cask NTC Structural Evaluation \& Puncture Threshold

Clsecker: ... R.J. Smith

Assuming the test rod is a hard unyiclding object, at this velocity $(<10,000 \mathrm{ft} / \mathrm{sec})$, the force that acts on the projectile is proportional to the cross sectional area and is essentially constant during penetration.

Cross sectional area of projectile: $A_{p}:=\pi \cdot \frac{{ }^{d} h^{2}{ }^{2}}{4} \quad A_{p}=1.25 \cdot \mathrm{in}^{2}$

Volume of material displaced per unit of energy constant (Rhinchart and Pearson, 1954, page 202, Table 12-1):

For steel: $\quad K_{S}:=0.2610^{-4} \cdot \frac{\mathrm{in}^{3}}{\mathrm{ft} \cdot \mathrm{lbf}}$

Depth of penctration into steck: $s_{s p}: \frac{1}{2}-m_{p} \cdot v_{o}^{2} \frac{K_{s}}{A_{p}} \quad s_{s p}=0.001 \cdot i n$

The penetration depth is not sigmificant, therefore no penetration of package.

PRTR Cask Puncture Failure Thresholds, Equivalent Steel Thickness:

Equivalent Thickness of lead to stecl (Rinchart, 1954): $\quad f_{\text {equ }}:=2.3$

ID of Outer Shell: id $03:=13.5 \mathrm{in} \quad$ Outer Shell Wall Thickness: $t_{0 \times 3}:=0.25 \mathrm{in}$

OD of Tnner Shell: od ${ }_{3}:=3.375$ in ID of Inner Shell: id $i 3:=3.125$ in

Inner Shell Wall Thickness: $\quad t_{\mathrm{iw} 3}: \frac{\mathrm{od}_{\mathrm{i}} 3^{-\mathrm{id}} \mathrm{i} 3}{2} \quad \mathrm{t}_{\mathrm{iw} 3}=0.125^{\circ} \mathrm{in}$

Lead Thickness: $\quad t_{\mathrm{pb} 3}: \frac{\mathrm{id}_{\mathrm{o} 3}-\mathrm{od} i 3}{2} \quad \mathrm{t}_{\mathrm{pb} 3}=5.06 \cdot \mathrm{in}$

Total Equivalent thickness of stcel: $\quad t_{\text {eq } 3}:=t_{\text {ow }}+t_{i w 3}+\frac{t_{p b 3}}{f_{e q u}} \quad t_{e q 3}=2.6 \cdot$ in 
HNF-SD-TP-SEP-063, Rev. 0

This page intentionally left blank. 


\subsection{THERMAL EVALUATION}

\subsection{INTRODUCTION}

The PRTR Graphite Cask is an onsite, intra-area packaging for transporting Type B radioactive material within the 300 Area of the Hanford Site. This section of the document defines and evaluates the NTC structural requirements for intra-area transport of this package. Thermal performance of the package is evaluated onfy for NTC; accident conditions are evaluated in the risk and dose consequence section of this document.

\subsection{THERMAL EVALUATION OF PACKAGE}

\subsubsection{Package Description}

The PRTR Graphite Cask is fundamentally a right circular cylinder of lead and stainless steel composite construction. The lead is sandwiched between outer and inner stainless steel tubular shells. At each end of the cask is a thick circular plate that is welded to both inner and outer shells, which encapsulates the lead. At the top, closure of the inner cavity is provided by a bolted blind flange with an attached shield plug of composite lead-stainless steel construction. The cask is equipped with a manually actuated, sliding trap door, which provides closure at the bottom end. None of the end closures are sealed. A handling yoke is provided on the cask and welded to the outer shell. In addition, support plates are welded to the outer housing of the cask to provide support during transport and lifting attachment anchors for handling.

The cask is constructed of welded 304L stainless steel. Shielding is provided by lead, which is poured after fabrication of the stainless steel body and internal components.

\subsection{NORMAL TRANSPORT CONDITIONS THERMAL EVALUATION}

\subsubsection{Conditions To Be Evaluated}

Thermal performance of the package is assessed for Hanford Site NTC in this section. The package is evaluated for the worst-case Hanford Site thermal loading condition of a still-air ambient temperature of $46^{\circ} \mathrm{C}\left(115^{\circ} \mathrm{F}\right.$ [Fadeff 1992]) with decay heat sources with and without solar insolation. Because of the variability of the payloads, the heat sources are assumed to be tightly packed in the cask cavity and against the inside wall of the cask.

\subsubsection{Acceptance Criteria}

The criterion for acceptable performance of the package is the accessible surface of the package in still air at $46^{\circ} \mathrm{C}\left(115^{\circ} \mathrm{F}\right)$ and in the shade is not to exceed $82^{\circ} \mathrm{C}\left(182^{\circ} \mathrm{F}\right)$. This is based on this package being transported as an exclusive-use shipment.

\subsubsection{Thermal Evaluation and Conclusions}

For this evaluation the worst-case decay heat source is assumed to generate a total heat load of $5.65 \mathrm{~W}$. Based on the variable geometries of the payloads, the configuration of the heat source is assumed to be uniformly distributed over the length of the cask cavity and fitted tightly up against the inside wall of the cavity. This provides a conservative estimate of the cask temperature, but it does 
not provide a conservative estimate of the temperature load to the payload. This evaluation bounds temperatures for the cask, but does not provide any estimation of payload temperatures. Temperaturesensitive payloads must be evaluated on a case-by-case basis to determine the temperature parameters within the cask.

Results of this evaluation show the cask component temperatures under solar insolation are below $99^{\circ} \mathrm{C}\left(211^{\circ} \mathrm{F}\right)$ for the structural evaluation. The results also show the cask meets the NTC exterior surface temperature requirement of $82^{\circ} \mathrm{C}\left(182^{\circ} \mathrm{F}\right)$ in the shade for exclusive-use shipments. Table B2-2 shows a heat loading of $2.92 \mathrm{~W}$ resulting from a reduced payload. Because the heat loading is less than the previously analyzed heat loading, the thermal evaluation conclusion remains the same.

\subsection{REFERENCE}

Fadeff, J. G., 1992, Environmental Conditions for On-site Hazardous Materials Packages, WHC-SD-TP-RPT-004, Rev. O, Westinghouse Hanford Company, Richland, Washington: 


\subsection{APPENDIX: PRTR GRAPHITE CASK NTC THERMAL EVALUATION}

\section{ENGINEERING SAFETY EVALUATION}

Subject: PRTR Cask Normal Transport Eon trions Thermal Evaluation

I. Objective:

The objective of this evaluation is determine the cask component temperatures under solar insolation for the structural evaluation and the exterior temperature in the shade as specified in Section 8 of this Safety Evaluation for Packaging (SEP).

II. References:

Irwin, J. J., 1995, WHC-SD-TP-RPT-005, Rev. 1, Thermal Analysis Methods for Safety Analysis Reports for Packaging, Westinghouse Hanford Company, Richland, Wash.

ORNL, 1970, Cask Designer's Guide, ORNL-NISC-68, Oak Ridge National Laboratory, Oak Ridge, Tennessee.

Mathcad Plus 5, 1994, User's Guide, Math Soft Inc., Cambridge, Massachusetts.

WHC, 1980, Drawing No. H-3-13699, Rev. 7, PRTR Graphite Sample Cask Assy., Westinghouse Hanford Company, Richland, Washington.

III. Results and Conclusions:

The results also show the cask meets the normal transport conditions (NTC) exterior temperature requirement of $182^{\circ} \mathrm{F}$ in the shade for exclusive use shipments. Because of the variability of the payloads, the heat sources are assumed to be tightly packed in the cask cavity and against the inside wall of the cask. This provides a conservative estimate of the peak temperatures subjected to the cask, but it does not provide a conservative estimate of the payload temperatures. Temperature sensitive payloads must be evaluated on a case by case basis to verify payload stability and integrity. 


\section{Evaluation:}

\section{Normal Transport Conditions (NTC) Thermal Evaluation:}

Determine temperature of outer shell with and without solar insolation:

Evaluate as steady state heat transfer for a horizontal cylinder with flat plate ends (Irwin, 1995):

Free convection coefficient for a horizontal cylinder: $\quad \mathrm{k}_{\mathrm{hc}}:=0.27 \cdot \frac{\mathrm{BTU}}{\mathrm{hr} \cdot \mathrm{ft}^{2}}$

Free convection coefficient for a vertical plate: $\quad \mathrm{k}_{\mathrm{vp}}:=0.29 \frac{\mathrm{BTU}}{\mathrm{hr} \cdot \mathrm{fl}^{2}}$

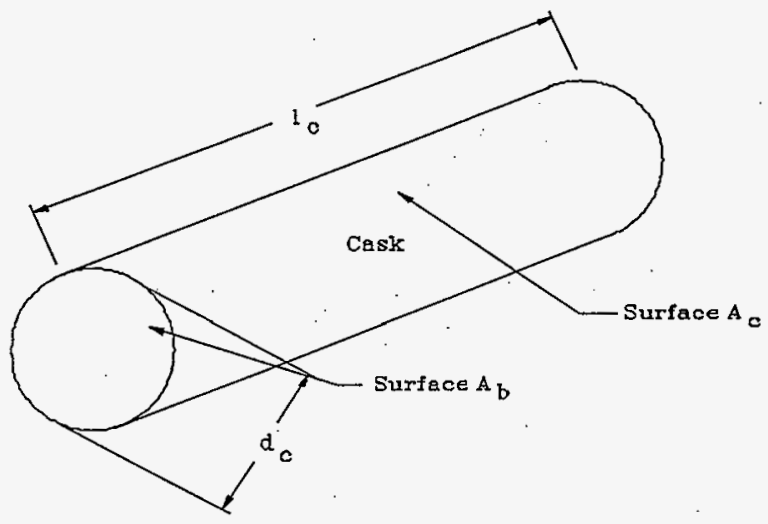

Length of cylinder: $\quad I_{c}:=39$ in $\quad$ Diameter of plate: $\quad d_{c}:=14$ in

Surface area of cylinder: $\quad A_{c}:=\pi \cdot 1 \cdot d c \quad$ Surface area of plate: $\quad A_{b}:=\frac{\pi}{4} \cdot d c$

Convection coefficients:

$$
h_{1}:=\frac{k_{h c} \cdot A_{c} \cdot R^{-\frac{1}{4}}}{\left(\frac{l_{c}}{f t}\right)^{-\frac{1}{4}}} \quad h d_{2}:=\frac{k_{v p} \cdot 2 \cdot A_{b} \cdot R^{-\frac{1}{4}}}{\left(\frac{d_{c}}{f t}\right)^{-\frac{1}{4}}}
$$


Radient heating constant:

$$
\text { Stefan-Boltzman's natural constant: } \quad \sigma_{\mathrm{sb}}:=0.171410^{-8} \cdot \frac{\mathrm{BTU}}{\mathrm{hr} \cdot \mathrm{ft}^{2} \cdot \mathrm{R}^{4}}
$$

Emissivity of stainless steel: $\quad \varepsilon_{s}:=0.32$

$$
\text { Radiation coefficients } \quad \mathrm{K}_{1}:=\sigma_{\mathrm{sb}} \cdot{ }^{\varepsilon} \mathrm{s} \cdot \mathrm{A}_{\mathrm{c}} \quad \mathrm{K}_{2}:=\sigma_{\mathrm{sb}} \cdot \varepsilon_{\mathrm{s}} \cdot \mathbf{2} \cdot \mathrm{A}_{\mathrm{b}}
$$

Solar heat loading (Inwin, 1995), hourly average loading based on a $12 \mathrm{hr}$ period:

Curved surfaces: $\quad Q_{s 1}:=314 \frac{\text { watt }}{\mathrm{m}^{2}} \quad Q_{s 1}=99.54 \cdot \frac{\mathrm{BTU}}{\mathrm{hr} \cdot \mathrm{ft}^{2}}$

Non-vertical surfaces, flat surfaces: $Q_{s}:=\frac{Q_{s 1}}{2} \quad Q_{S}=49.77 \cdot \frac{\mathrm{BTU}}{\mathrm{hr} \cdot \mathrm{f}^{2}}$

Internal heat load: $q_{\text {int }}:=5.65$ watt $\Rightarrow$

Assumed solar absorptivity: $\quad \alpha_{\text {sol }}:=0.57$

Solar heat load: $\quad q_{\text {sol }}:=\alpha_{\text {sol }} \cdot\left(Q_{s} \cdot \frac{A_{b}}{2}+Q_{s 1} \cdot A_{c}\right)$

Total heat load: $\quad q_{\text {tot }}:=q_{\text {sol }}+q_{\text {int }} \quad q_{\text {tot }}=710 \cdot \frac{B T U}{h r}$

Outside ambient temperature is $115^{\circ} \mathrm{F}$ and in Rankine: $\quad T_{0}:=(115 \div 459.7) \cdot R$

Using conservation of energy: $\quad q_{\text {in }}-q_{\text {out }}=0$

Then by substitution: $\quad q_{\text {tot }}-q_{\mathrm{rad}}-q_{\text {con }}=0 \quad$ or

$q_{\text {tot }}-K_{1} \cdot\left(T_{f}^{4}-T_{o}^{4}\right)-K_{2} \cdot\left(T_{f}^{4}-T_{o}^{4}\right)-h d 1_{1} \cdot\left(T_{f}-T_{0}\right)^{\frac{1}{4}}-h d_{2} \cdot\left(T_{f}-T_{0}\right)^{\frac{1}{4}}=0$ 
Solve for $T_{f}$ which the temperature at the surface using MathCad roots of equation solution:

$$
T_{f 1}:=\operatorname{root}\left[q_{t o t}-K_{1} \cdot\left(T_{f}^{4}-T_{0}^{4}\right)-K_{2} \cdot\left(T_{f}^{4}-T_{o}{ }^{4}\right)-h d_{1} \cdot\left(T_{f}-T_{0}\right)^{\frac{1}{4}}-h d_{2} \cdot\left(T_{f}-T_{o}\right)^{\frac{1}{4}}, T_{f}\right]
$$

External surface temperature in sun:

Temperature in ${ }^{\circ} \mathrm{F}: \quad \mathrm{T}_{\mathrm{ff}}:=\left|\frac{\mathrm{T}_{\mathrm{f1}}-459.7 \mathrm{R}}{\mathrm{R}}\right| \quad \mathrm{T}_{\mathrm{ff}}=208$

Temperature in Shade:

Total shaded heat load: $\quad q_{\text {stot }}:=q_{\text {int }}$

Solve for $T_{\mathbf{f}}$ which the temperature at the surface using MathCad roots of equation solution:

$$
T_{f 2}:=\operatorname{root}\left[q_{\text {stot }}-K_{1} \cdot\left(T_{f}^{4}-T_{0}^{4}\right)-K_{2} \cdot\left(T_{f}^{4}-T_{0}{ }^{4}\right)-h d_{I} \cdot\left(T_{f}-T_{0}\right)^{\frac{1}{4}}-h d_{2} \cdot\left(T_{f}-T_{0}\right)^{\frac{1}{4}}, T_{f}\right]
$$

External surface temperature in shate: $\quad \mathrm{T}_{\mathrm{f} 2}=577^{*} \mathrm{R}$,

Temperature in ${ }^{\circ}: \quad T_{\text {ff2 }}:=\left|\frac{T_{f 2}-459.7 R}{R}\right| \quad T_{\text {ff2 }}=117$

With this simplified model determine temperature of inner shell with solar insolation:

Assume as one-dimensional heat transfer and internal heat source is against inside shell wall, no gap.

$$
q_{\text {tot }}=\frac{2 \cdot \pi \cdot t_{c} \cdot\left(\mathrm{r}_{1}-\mathrm{T}_{4}\right)}{\frac{\ln \left(\frac{\mathrm{r}_{2}}{\mathrm{r}_{1}}\right)}{\mathrm{k}_{\mathrm{sst}}}+\frac{\ln \left(\frac{\mathrm{r}_{3}}{\mathrm{r}_{2}}\right)}{\mathrm{k}_{\mathrm{pb}}}+\frac{\ln \left(\frac{\mathrm{r}_{4}}{\mathrm{r}_{3}}\right)}{\mathrm{k}_{\text {sst }}}}
$$




\section{HNF-SD-TP-SEP-063, Rev. 0}

\section{ENGINEERING SAFETY EVALUATION}

Subject: PRTR Cask Normal Transport Conditions Thermal Evaluation

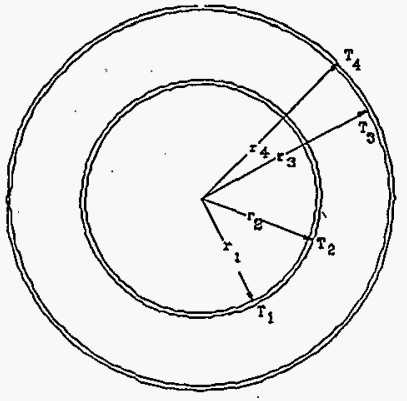

$$
\begin{array}{ll}
\text { Inner shell inside radius: } & r_{1}:=\frac{3.125 \mathrm{in}}{2} \\
\text { Inner shell outside radius: } \mathrm{r}_{2}:=\frac{3.375 \mathrm{in}}{2} \\
\text { Outer shell inside radius: } \quad r_{3}:=\frac{13.5 \mathrm{in}}{2} \\
\text { Outer shell outside radius: } \quad \mathrm{r}_{4}:=\frac{\mathrm{d}_{\mathrm{c}}}{2}
\end{array}
$$

Outer shell temperature, for full solar insolation:

$$
\mathrm{T}_{4}:=\mathrm{T}_{\mathrm{ff}}
$$

Thermal properties of materials:

Conductivity (Irwin, 1995):

$$
\text { Lead at } 212 \circ \mathrm{F}: \quad \mathrm{k}_{\mathrm{pb}}:=0.000447 \frac{\mathrm{BTU}}{\mathrm{sec} \cdot \mathrm{in}} \quad 304 \mathrm{~L} \text { stainless steel at } 200^{\circ} \mathrm{F}: \mathrm{k}_{\mathrm{sst}}:=0.000215 \frac{\mathrm{BTU}}{\mathrm{sec} \cdot \mathrm{in}}
$$

Solve heat transfer equation for inner temperature:

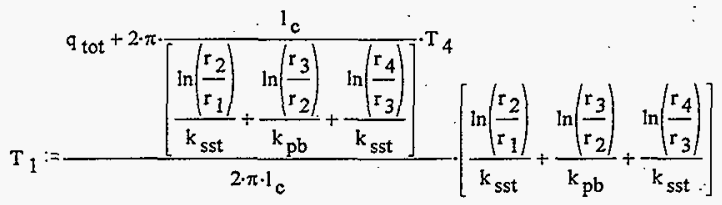

Inside temperature of inner shell ( $\left.{ }^{\circ} \mathrm{F}\right): \quad \mathrm{T}_{1}=211$ 
HNF-SD-TP-SEP-063, Rev. 0

This page intentionally left blank. 
HNF-SD-TP-SEP-063, Rev. 0

\subsection{PRESSURE AND GAS GENERATION EVALUATION}

Only dry contents are authorized for the PRTR Graphite Cask. Therefore, there are no pressure or gas generation concerns. 
HNF-SD-TP-SEP-063, ReV. 0

This page left intentionally blank.

B9-2 


\subsection{TIEDOWN EVALUATION}

\subsection{SYSTEM DESIGN}

The PRTR Graphite Cask shall be centered and placed horizontally on the bed of the trailer for shipment. The long axis of the cask is centered along the long axis of the trailer. In accordance with the regulations, the tiedowns must have an aggregate working capacity of one-half the cask weight.

The package is to be secured in accordance with DOT regulations (49 CFR 393.100). The cask is to be secured to the trailer by two sets of tiedowns as shown in Figure 10-1. One set acts as chocks to block and brace the cask from horizontal movement. The other set acts as vertical restraints. There are two $4 \times 4$ wood blocks placed at each end of the cask. These $4 \times 4$ blocks have a $2 \times 2$ nailed to the side at the bottom to form landings for the tiedowns. Each of the chocking tiedowns is looped around the cask from opposite sides of the trailer and attached to the trailer. The chocking tiedowns lay on the landing and bear against the wood blocks when drawn tight. The vertical restraint tiedowns are placed over the cask on each side of the lifting yoke. These tiedowns are then attached to the trailer on opposite sides and drawn tight.

Figure 10-1. Cask Tiedown Configuration.

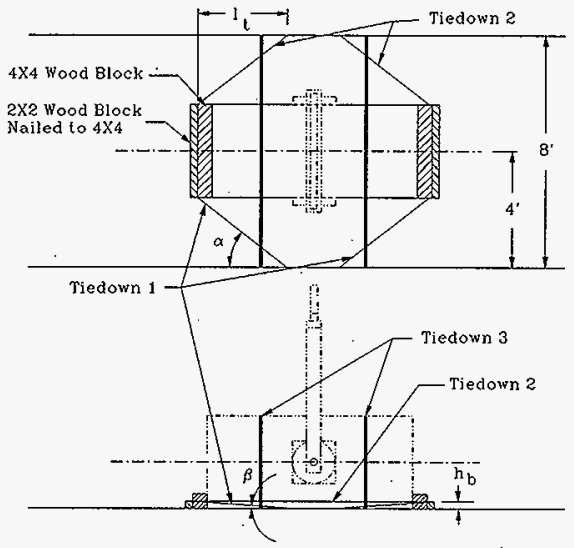

Note:Tiedowns $\$ \&$ go eround cask

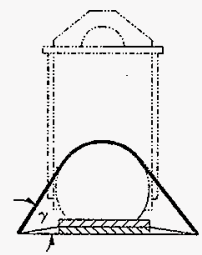




\subsection{ATTACHMENTS, RATINGS, AND REQUIREMENTS}

Each tiedown and trailer attachment point must have a minimum working strength of $11,120 \mathrm{~N}(2,500 \mathrm{lb})$. The $2 \times 2$ wood blocks must be nailed to the $4 \times 4$ wood blocks with a minimum of three $10 \mathrm{~d}$ nails. The length of the blocks is specified as the same as the diameter of the cask to within a tolerance of $0.32 \mathrm{~cm}(1 \%$ in. $)$.

\subsection{REFERENCE}

49 CFR 393.100, 1997, "Parts and Accessories Necessary for Safe Operation," Code of Federal Regulations, as amended. 
HNF-SD-TP-SEP-063, Rev. 0

10.4 APPENDIX: ENGINEERING SAFETY EVALUATION

\section{ENGINEERING SAFETY EVALUATION}

Subject: 327 PRTR Cask Tiedown Evaluation

Preparer: S.S. Shiraga

Section Chief: S. S. Shiraga

Page 1 of 3

Date $07 / 21 / 97$

Date

Date

\subsection{OBJECTIVE}

The objective of this evaluation is to determine the capacity and configuration of the tiedown system for the 327 PRTR Cask. The tiedowns are specified to the requirements of 49 CFR 393.100 .

\subsection{REFERENCES}

49 CFR 393.100, 1995, "Protection Against Falling Cargo," Subpart I, Code of Federal Regulations, as amended.

\subsection{ASSUMPTIONS, RESULTS, AND CONCLUSIONS}

As defined in this document, shipment of the 327 PRTR cask within the 300 Area is authorized under a risk based assessment. Consequently, the tiedown system must be an engineered system to ensure that the package remains on the conveyance during all normal non-accident conditions. Since the shipment is only within the 300 Area, the system is specified based on the requirements of 49 CFR 393.100 .

As shown in the evaluation, the cask is assumed to be centered on a standard flat bed trailer and the lifting yoke placed in the vertical position. The system consists of two $4 \times 4$ wood blocks with $2 \times 2$ wood blocks nailed to them, forming an " $L$ " shape. These " $L$ " shaped blocks span the width of the cask and are placed at each end. Two cables or chains are looped around the cask and blocks from each side and drawn tight. The cables or chains rest on the landing formed by the " $\mathrm{L}$ " shape of the blocks. This forms the blocking and bracing to restrain longitudinal and lateral loads. Placed over the cask on each side of the lifting yoke are two tiedown straps, cables, or chains to provide vertical restraint. The minimum specified working strength of the tiedowns is $2,500 \mathrm{lb}$. The wood blocks are to be constructed from standard commercial grade lumber. The $2 \times 2$ blocks are to be nailed to the $4 \times 4$ blocks with a minimum of three $10 \mathrm{~d}$ nails. 
Subject: 327 PRTR Cask Tiedown Evaluation

Preparer: S. S. Shiraga

Page 2 of 3

Checker: P. C. Ferrell

Section Chief:S.S. Shiraga

\subsection{EVALUATION}

\section{PRTR Cask Tiedown Evaluation:}

OD of cask: od cask $:-14$ in Length of cask: $1_{\text {cask }}:=39.625$ in

Gross weight of cask: $\quad w_{\text {cask }}: 2650 \mathrm{lbf} \quad$ DOT inertial load factor: $\quad g_{\text {dot }}:=0.5$

Chain height from deck: $\quad h_{b}:=1.5 \cdot$ in $\quad$ Length to trailer attachment: $I_{t}:=15 \cdot$ in

Load on tiedowns: $\quad \mathrm{F}_{\mathrm{ch}}:=\mathrm{g}_{\mathrm{dot}} \cdot \mathrm{w}_{\text {cask }} \quad \mathrm{F}_{\mathrm{ch}}=1325 \cdot \mathrm{lbf}$

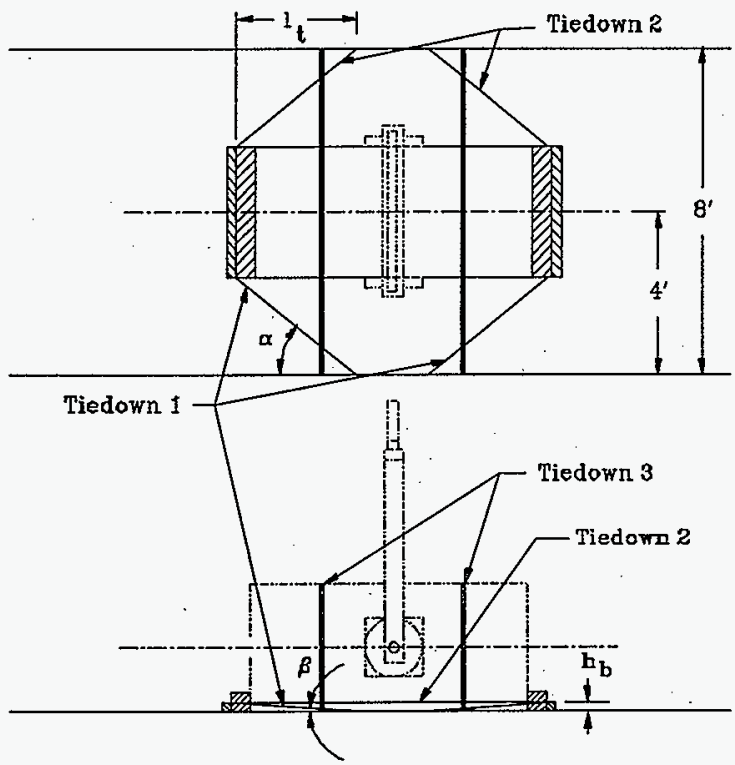

Nate:Tiedowns 182 go eround cask

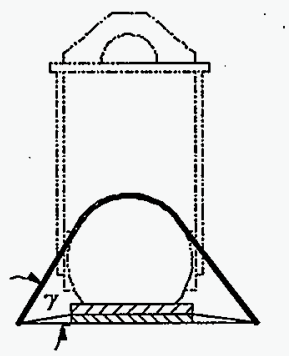


Subject: 327 PRTR Cask Tiedown Evaluation

Preparer: S. S. Shiraga

Checker: P.C. Ferrell PPf

Page 3 of 3

Section Chief: S. S. Shiraga

Angle off horizontal: $\quad \alpha:=\operatorname{atan}\left[\frac{48 \cdot \mathrm{in}-\frac{\text { od cask }}{2}}{1_{t}}\right] \quad \alpha=69.9 \cdot \mathrm{deg}$

Angle off vertical: $\quad \beta:=\operatorname{atan}\left(\frac{h_{b}{ }^{-\cos (\alpha)}}{l_{t}}\right) \quad \beta=2 \cdot d e g$

Determine chocking tiedowns:

Tension on lateral chain only one tiedown acting: $\quad T_{\text {lat }}:=\frac{F_{\text {ch }}}{\sin (\alpha) \cdot \cos (\beta)} \quad T_{\text {lat }}=1412 \cdot \mathrm{lbf}$

Tension on longitudinal chain, two tiedowns acting: $\quad T_{\text {long }}:=\frac{F_{\text {ch }}}{2 \cdot(\cos (\alpha) \cdot \cos (\beta))} \quad T_{\text {long }}=1929 \cdot \mathrm{lbf}$

Determine tiedowns:

Vertical tiedown angle: $\quad \gamma:=\operatorname{atan}\left(\frac{\text { od }_{\text {cask }}}{4 \cdot \mathrm{ft}}\right) \quad \gamma=16.3^{\circ} \mathrm{deg}$

Tension in vertical tiedowns: $\quad T_{\text {ver }}:=\frac{F_{\text {ch }}}{2 \cdot \sin (\gamma)} \quad T_{\text {ver }}=2366^{\circ} \mathrm{lbf}$

Based on above, minimum working load of all tiedowns is specified as $2,500 \mathrm{lb}$. 
DISTRIBUTION SHEET

\begin{tabular}{|c|c|c|c|c|c|c|}
\hline \multirow{2}{*}{$\begin{array}{l}\text { To } \\
\text { Distribution }\end{array}$} & & \multirow{2}{*}{\multicolumn{3}{|c|}{$\begin{array}{l}\text { From } \\
\text { Packaging Engineering }\end{array}$}} & \multicolumn{2}{|l|}{ Page 1 of 1} \\
\hline & $\mathrm{Pac}$ & & & & \multicolumn{2}{|c|}{ Date Sept. 24, 1997} \\
\hline \multicolumn{5}{|l|}{ Project Title/Work Order } & \multicolumn{2}{|c|}{ EDT No. 621885} \\
\hline \multicolumn{5}{|c|}{$\begin{array}{l}\text { Safety Evaluation for Packaging (Onsite) Plutonium Recycle Test } \\
\text { Reactor Graphite Cask (HNF-SD-TP-SEP-063, Rev. 0) }\end{array}$} & \multicolumn{2}{|l|}{ ECN No. $\quad \mathrm{N} / \mathrm{A}$} \\
\hline Name & & MSIN & $\begin{array}{l}\text { Text } \\
\text { With All } \\
\text { Attach. }\end{array}$ & Text Only & $\begin{array}{l}\text { Attach./ } \\
\text { Appendix } \\
\text { Only }\end{array}$ & $\begin{array}{l}\text { EDT/ECN } \\
\text { Only }\end{array}$ \\
\hline $\begin{array}{l}\text { R. L. Clawson } \\
\text { J. G. Field } \\
\text { C. R. Hoover } \\
\text { S. B. Johnston }\end{array}$ & . & $\begin{array}{l}H I-14 \\
H 1-15 \\
H 1-15 \\
L 1-03\end{array}$ & $\begin{array}{l}X \\
x \\
x \\
x\end{array}$ & & . & . \\
\hline $\begin{array}{l}\text { HNF-SD-TP-SEP-063 File } \\
\text { P97-046 (D. KeTly) } \\
\text { Central Files }\end{array}$ & $\therefore$ & $\begin{array}{l}H 1-15 \\
H 1-15 \\
\text { A3-88 } \\
\end{array}$ & $\begin{array}{l}x \\
X \\
\end{array}$ & & & $x$ \\
\hline
\end{tabular}

